\title{
Rearticulating the State through Governmental Regimes: State Power and Popular and Indigenous Participation in Ecuador 2008-2012
}

by

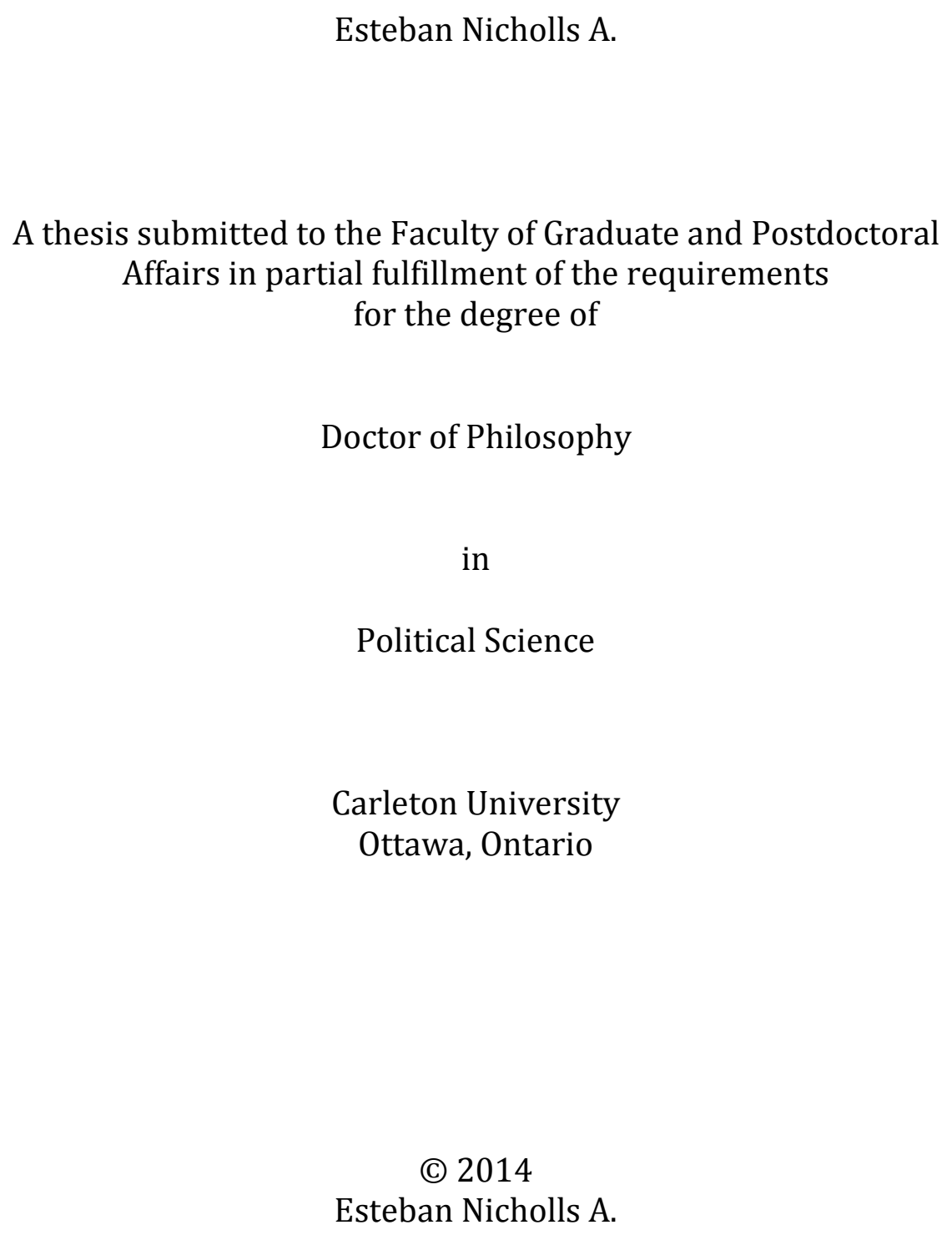

Esteban Nicholls A. 


\begin{abstract}
This dissertation is a study of the processes of state formation and reproduction in Ecuador between 2008 and 2012. In particular, it analyzes three specific areas of state formation: first, the formation of narratives about the state seeking to legitimize its presence in society. More specifically, it analyses how the state incorporates narratives emerging from indigenous peoples' worldviews into the state apparatus and the ways in which these enter in tension with "developmentalist" narratives. Second, it investigates the various ways in which the state apprehends, organizes, distributes and ultimately creates specific fields of intervention in the area of participatory planning; and third, the ways in which the state exercises different and complementary modalities of state power in the government of participation popular movements, particularly the indigenous movement. This dissertation's general argument is that the state reproduces itself by creating spaces where it can legitimately intervene in society. Moreover, it contends that the Ecuadorian state has reconfigured and strengthened its presence in society through a combination of modern techniques of power rooted on a technocratic, knowledge-intensive form of government as well as disciplinary techniques of rule based on the correction and reformation of particular populations. In this sense, this dissertation posits that there is a governmental effort to "technify" and depoliticize participation in order to make it more governable, and that popular participation outside of the state is met with disciplinary acts.
\end{abstract}




\section{Acknowledgements}

First, I would like to thank my supervisor Dr. Cristina Rojas. Dr. Rojas's encouragement was invaluable in believing in and challenging my own ideas on a constant basis. Needless to say, throughout the process that led to this work, Dr. Rojas was a continuous source of intellectual inspiration and personal support. I would also like to thank Dr. Laura MacDonald and Dr. Hans-Martin Jaeger. Both Dr. MacDonald and Dr. Jaeger were instrumental in always taking my ideas a step further. I want to thank my amazing parents Pilar and Esteban Mariano and my wonderful sister, Gabriela, for their continuous support and unshaken believe in me, my work and my aspirations. I am also deeply grateful to my parents-in-law, Rita and Wayne for always making me feel positive about my ideas and capabilities. Thanks to my inspirational grandmother, Nené, for all her strength. This work would not have been possible without the presence in my life of my brother and best friend, Juan Javier. This is for your heart. And above all, I would like to thank Karen, my partner in life, my teacher, my most optimistic critic, my source of inspiration... my love. 


\section{Table of Contents}

Abstract I

Acknowledgements ii

Table of Contents iii

List of Images, Tables and Maps v v

List of Acronyms and Abbreviations vi

Chapter One: Introduction $\quad 1$

1.1 Research Questions and Arguments $\quad 7$

1.2 Methodological Considerations $\quad 11$

1.3 Broader Methodological Tradition: Interpretivism 12

1.4 A Historical Approach: Genealogy 14

1.5 Reflexivity 17

1.6 Methodological Tools 18

1.7 The Analysis of Narratives and Representations 22

1.8 The Organization of this Work 24

Chapter Two: The Literature and Theoretical Contributions:

Governmentality, Regimes of Government and the State 32

2.1 The Literature, Situating this Work's Main Arguments and Debates 32

2.2 Main Debates and Theoretical Sources in the Ecuadorianist Literature $\quad 32$

2.3 Situating the Debate within Broader Intellectual Traditions 45

2.4 Studying the Practices and Engagements of the Ecuadorian State 55

2.5 Governmentality and the State? 62

2.6 Studying the State as Governmental Regimes 64

2.7 The State Apparatus $\quad 67$

2.8 The State and Modalities Power $\quad 69$

2.9 Knowledge, Power and Government 76

2.10 Regimes, Practices and Technologies of Government 82

2.11 Governmentality's Historical Stance $\quad 90$

2.12 Politics and De-Politicization 93

2.13 Marginalized Populations, Governmental Regimes and Resistance to Power 98

2.14 Problems with Governmentality 104

Chapter Three: A Genealogy of the Ecuadorian State and the Co-Constitution of State and Society 114

$\begin{array}{ll}3.1 \text { Introduction } & 114\end{array}$ 
3.2 The State, Participation and Social Forces in Historical Perspective

3.3 The National Period: Creole Elites and the Constitution of Indian Others: 1830-1949

3.4 The Transition period: 1950-1978: The Incorporation of Indigenous Populations into a National Project and the Emergence of Modern Forms of Rule

3.5 The Construction of The New Citizen, the Early Neoliberal State and the Birth of CONAIE: 1979-1990

3.6 The Apogee of CONAIE and the Indigenous Movement, 1990-2002 and the Peak of Neoliberal Reform

3.7 Contextualizing the Election of Rafael Correa, 2006-2007

3.8 The Years Leading to the 2008 Constituent Assembly and the Crisis of CONAIE $2002-2008$

Chapter Four: The Narratives of State Formation 2008-2012

163

4.1 Introduction

4.2 On the Conflicting Narratives and Practices of Statecraft

166

4.3 State Narratives in the Process of State Formation:

Sumak Kawsay/Buen Vivir and the Civilizational Challenge

to Development

168

4.4 Modernizing Neo-Developmentalism

174

4.5 Defining the State as Image: Narratives about Development, Progress and Sumak Kawsay/Buen Vivir

178

4.6 Modernizing-Neodevelopmentalism and the "Efficient" State

179

4.7 The Neo-Developmental State in Practice: Structural Reforms and Extractivism

4.8 The Modernizing Neo-Developmental State: Construing the Image of "Modern"

Chapter Five: Constructing the State through Governmental Regimes

5.1 Introduction

5.2 Governmental Regimes and Improvement: Developmentalism as a Regime of Improvement

5.3 Discourses, Knowledge and the State

5.4 Defining Governmental Regimes: The Case of SENPLADES 200

5.5 SENPLADES and the Articulation of the State

5.6 The Reconfiguration of Rule: SENPLADES and the "De-concentration" and "Decentralization" of the State 207

5.7 Participation, Indigenous Peoples and the Re-Spatialization of the State 208 
5.8 SENPLADES and Government

5.9 SENPLADES and Reverse Auto-Ethnography and the PNBV

5.10 Sumak Kawsay/Buen Vivir and Developmentalism in the PNBV: 2007-2010, 2009-2013

5.11 An Analysis of the 2009-2013 PNBV

5.12 Problematization in Action: Opening Up Spaces of Government in the PNBV

Chapter Six: The Construction and Government of Participatory Citizenship

238

6.1 Introduction

238

6.2 Participation, Citizenship and the State

6.3 Institutional Analysis of Participation: Openings and Closings as a form of Governmentality

238

240

6.4 Participation, Citizenship and Populations

246

6.5 Constructing Participation: The Micromanagement of Populations in the Plan Nacional del Buen Vivir

252

6.6 Techniques of Intervention Continued: "Capturing" participation

280

6.7 Reproducing the State: The PNBV Workshops and Microspaces of Government

284

6.8 Subalternity and the PNBV Workshops

287

6.9 The Case of "Plebiscitary Democracy" and Liberal techniques of Rule

291

6.10 Plebiscitary Democracy and Political Parties

294

6.11 Plebiscitary Democracy and Citizenship

295

6.12 Other States: and Forms of Participation

Chapter Seven: State Formation and the Government of Participation through Discipline

305

7.1 Introduction

306

7.2 Protecting the Regime of Improvement

307

7.3 Discipline, Indigenous peoples and the State 309

7.4 The Emergence of Disciplinary Power: The two stages of Indigenous movement-state relations

7.5 Exercising Disciplinary Power: A Discourse Analysis of Correa's Responses to Indigenous Protest between 2008-2012 from a historical perspective

7.6 The Three Techniques of Disciplinary Government

7.7 Final Reflections: Political Activism and Institutional Autonomy as a Historical Struggle of Indigenous Peoples 
Chapter Eight: Conclusion

8.1 Theoretical Contributions Revisited

352

8.2 Opportunities for Future Research

355

Bibliography

361

Appendices

388 


\section{List of Images}

Image $1 \quad$ Buen Vivir Billboard in Quito 175

Image 2 Developmental billboard:

“We have first-rate highways. We have a Homeland!" 188

Image 3 Developmental Billboard:

"We Have Efficient Airports. We have a Homeland!" 188

Image 4 Developmental Billboard:

"Electricity is Progress, like your Revolution"

Image 5 Developmental Billboard:

"Much Better if it's Made in Ecuador"

Image 6

Form:

"Management of Demands and Compromises from the Itinerant Cabinet" 


\section{List of Tables}

Table 1 The Knowledge Production of SENPLADES 204

$\begin{array}{lll}\text { Table } 2 & \text { PNBV 2009-2013 Objectives } & 219\end{array}$

Table 3 Phases of the Endogenous Strategy for

Satisfying Basic Needs 223

Table $4 \quad$ List of Charts, Tables and Maps in Objective 3 of the PNBV 2009-2013 228

$\begin{array}{lll}\text { Table } 5 & \text { Policies and Guidelines } & 229\end{array}$

$\begin{array}{lll}\text { Table } 6 & \text { Specific Objectives }\end{array}$

Table 7 Participatory Spaces for the Construction of the PNBV 257 


\section{List of Maps}

Map 1 Indigenous Peoples Territorial Self-Representation: Indigenous Nations and Peoples 214

Map 2 Representation of Territory by SENPLADES:

Zones, Districts and Circuits 215

$\begin{array}{lll}\text { Map } 3 & \text { SENPLADES' regional subdivisions }\end{array}$ 


\section{List of Acronyms and Abbreviations}

\begin{tabular}{|c|c|}
\hline AP & Allianza PAIS \\
\hline BV & Buen Vivir \\
\hline CONAM & Consejo Nacional de Modernización \\
\hline CONAIE & Confederación de Nacionalidades Indigenas del Ecuador \\
\hline CONFENIAE & $\begin{array}{l}\text { Confederación de Nacionalidades Indígenas de la Amazonia } \\
\text { Ecuatoriana }\end{array}$ \\
\hline ECLAC & Economic Commission for Latin America and the Caribbean \\
\hline HDA & Human Development approach (HDA) \\
\hline IERAC & Instituto Ecuatoriano de Reforma Agraria y Colonización \\
\hline IMF & International Monetary Fund \\
\hline FTAA & Free Trade Agreemen of the Americas \\
\hline DINEIB & Dirección Nacional de Educación Intercultural Bilingüe \\
\hline MOSEIB & Modelo del Sistema de Educación Intercultural Bilingüe \\
\hline CODENPE & $\begin{array}{l}\text { Consejo de Desarrollo de los Pueblos y Nacionalidades Indígenas del } \\
\text { Ecuador }\end{array}$ \\
\hline FEI & Federación Ecuatoriana de Indios \\
\hline FENOCIN & $\begin{array}{l}\text { Confederacion Nacional de Organizaciones Campesinas Indigenas y } \\
\text { Negras }\end{array}$ \\
\hline FICSH & Federación Indigena de Centros Shuar \\
\hline NGO & Non Governmental Organizations \\
\hline PNBV & Plan Nacional para el Buen Vivir \\
\hline SENPLADES & Secretaria Nacional de Planificación y Desarrollo del Ecuador \\
\hline SK & Sumak Kawsay \\
\hline SK/BV & Sumak Kawsay/Buen Vivir \\
\hline WPR & Weekly Presidential Reports \\
\hline
\end{tabular}




\section{CHAPTER ONE}

\section{INTRODUCTION}

This dissertation is a study of the processes of state formation in Ecuador between 2008 and 2012. More specifically, it is interested in making intelligible the post2008 state as it penetrates society through forms of governmentality. This dissertation investigates the processes through which the state constructs different narratives and images about itself in order to legitimize and generate consent as it seeks to penetrate society; at the level of practices, it looks at specific practices of government, particularly the government of participation and how participation is itself a form of government. To look at the governmentality of participation I conducted primary research on the development of the state's most important participatory planning document: the Plan Nacional del Buen Vivir, 2013-2017 (National Plan for the Good Living 2013-2017 - PNBV), by investigating its preparatory workshops between 2011-2012. Finally, to bring these elements together, this study focuses on the different modalities of state power, particularly as they are exercised in the field of participatory politics. To do so, it analyses the relationship between the state and indigenous populations, particularly its relationship with the Confederación de Pueblos y Nacionalidades Indígenas del Ecuador (the Confederation of Indigenous Peoples and Nationalities of EcuadorCONAIE).

The Preamble of the Constitution of Ecuador, approved by popular vote in 2008, states that the objective of the Ecuadorian nation is to construct "A new form 
of coexistence between citizens, in diversity and in harmony with nature, in order to reach the Good Living, the Sumak Kawsay" (Constitution of Ecuador, 2008: Preamble). In Article 103, it defines Ecuador as a "direct democracy" rooted in the right of citizens to directly participate "in all public affairs" (Constitution of Ecuador, 2008: Articles 103, 95). It also redefines Ecuador's economic system through the principles of reciprocity and solidarity. At the centre of the Constitution lies a radical ethos, influenced by indigenous peoples' philosophies (Walsh, 2010) encompassed in the concept of Sumak Kawsay/Buen Vivir, that propose not only to move away from traditional forms of capitalist development (see Escobar, 2010), but also away from the structures that constitute Eurocentric modernity itself (cf. Echeverria, 2010; Walsh, 2007).

For these and other reasons some have called the Ecuadorian Constitution the most "advanced" in existence (Acosta, 2010; see also Quintero Lopez, 2009). The current Constitution of Ecuador emerged after two and a half decades of neoliberal reforms, the near-complete collapse of the state's economy in 1999, and the successive overthrow of three democratically elected Presidents (see Chapter Three). It was written, as I will argue below, in a highly politicized period in which social movements, popular organizations, local non-governmental organizations (NGOs) and indigenous organizations participated in discussions about its content and principles (Acosta, 2008; Ortíz, 2012). The Ecuadorian Constitution may or may not be the "most advanced," but it is novel as far as Ecuadorian standards go. Beyond superlative adjectives, the constitutional articles cited above and indeed the entire Constitution reflect a specific historical period in which social forces, 
institutions and ideas (cf. Cox, 1981) within the country, as well as regionally, were moving away from neoliberalism. It was also born out of a historical context in which social and political forces, particularly at the popular level, demanded a transformation of the most fundamental structures of the country, most notably, the state and the economy; this meant the return of the state and the withering away of the market as the organizing principle in society.

However, the "return of the state" in this context was not simply something akin to a Polanyian-type (Polanyi, 1944) pendulum shift from the market to the state. After decades of neoliberalism, grass roots and popular organizations, particularly CONAIE, had fortified their own organizational structures (Ospina, 2010) and the classical notion of a strong state and a weak society (cf. Migdal, 1988) was no longer historically valid. Thus, demands from social movements were rooted in the notion of an organized civil society capable of participating alongside the state in issues of public interest; more importantly however, they incorporated the radical challenges encompassed in the indigenous philosophies of Sumak Kawsay or Buen Vivir $^{1}$ (SK/BV). SK/BV meant a civilizational, post-Marxist challenge to traditional forms of organizing the state, society and the economy. As far as the state goes the SK/BV principles demanded, among other things, the development of direct popular participation in "all public affairs," plurinationalism (which entailed the political autonomy of indigenous populations), and the institutionalization of practices like previous consultation and previous consent (see International Labour Organization, Tribal Peoples Convention, 1989: Art. 169).

\footnotetext{
${ }^{1}$ Sumak Kawsay is a Kichwa concept that is usually translated into English as "good living" and into Spanish as Buen Vivir.
} 
It is in this general context that the Secretaría Nacional de Planificacion y Desarrollo (National Secretariat for Planning and Development - SENPLADES) was created in 2007. SENPLADES is officially described as a "technical secretariat" whose objective is to develop forms of national planning that are "participatory, inclusive and coordinated in order to attain the Buen Vivir" (SENPLADES, 2014: http://www.planificacion.gob.ec/valores-mision-vision/) Similarly, Article 280 of the Constitution states that "The National Development Plan [the PNBV] is the instrument to which public policy, programs and projects will follow and adhere to...". And finally, both the Constitution as well as SENPLADES's mandate state that the PNBV is, above all, an instrument of participatory planning. Consequently, over 8000 non-state actors, including grass-roots level organizations participated in the formulation of the last PNBV - the one on which this dissertation's investigation is based (SENPLADES, PBNV 2013-2017, 2014: 37).

In short, the period between the election of current President Rafael Correa in 2006 and the enactment of the new Constitution in 2008 was a period of renewed hope in the capacity of the state to become instrumental in the construction of a post-neoliberal, post-development era (cf. Escobar, 1995, 2010) that is participatory, inclusive and open (see Macas, 2011). However, and notwithstanding the innovations of the Ecuadorian Constitution, much of the work for this new political project was still to be accomplished: the Ecuadorian state has been historically a relatively weak state (see Chapter Three), overridden with economic and political crises and a relatively limited penetration of society and in this sense, its return of the state as an inclusive, participatory entity was far from assured. 
Considering what was just mentioned, it is not surprising that much of the debate about Latin American politics as of late has revolved around the question of the state and its "return." But like many other processes of political changes in the past, one of the main "battles" is taking place lies the realm of interpretation: how to read this new wave of state comebacks, strengthening and expansion? What are its implications for society? Questions asked typically emerge out of a theoretical foundation and an ontological assumption that regard the state as a given. From this "solid" ground state actions are investigated but the state itself, particularly its reproduction, is largely unproblematized (see Chapter Two). Some of these questions concern the quality of democracy, the importance of the state in redistributing resources and/or in breaking the monopolization of political power by traditional elites. But, what if the state as a social ontology is not assumed but problematized? In a very general sense, this dissertation is about this question.

An important contribution made by French historian-philosopher Michel Foucault is to stress the importance of genealogy as a method for approaching research questions (Foucault, 1972, 1990, 1994b). Accordingly, this dissertation does away with the ontological foundation mentioned above and sets out to investigate the grounds upon which an entity called "the state" is reconfigured in its inner structures and rearticulates itself to be able to penetrate society as a form of government and rule in a post-neoliberal order. Thus, the general problematic that this dissertation addresses is the issue of state-formation and state-rearticulation. At a more specific level, it is interested in how the Ecuadorian state and its government of participation have been articulated since 2008; it is interested in 
how it exercises power and it its constitutive narratives and practices. The dissertation does not assume, however, that these processes have been successful it attempts to find out whether they have.

Little comprehensive research has focused on these questions. As was said, the state is generally assumed, not explained. It should not be surprising, nonetheless, that the state is often assumed and not problematized. States are complex realities and are notoriously difficult to theorize about (see Skocpol et al., 1985). This complexity is perhaps well reflected in Max Weber's definition of the state as an entity that possesses a monopoly over the legitimate means of violence within a given territory (Weber as referenced in Migdal, 2001: 89). Weber's definition, for good reasons, is limited. Making generalizations about the state is a complicated task and Weber's definition could be challenged through several historical examples. For instance, the Colombian state, a quite successful state in many respects, does not possess, it could be argued, a legitimate monopoly over the means of violence over its entire territory. Be that as it may, Weber's succinct definition is one of the most accepted and used definitions of the state. State theorizing or, more generally, developing a general theory about the state is, as Foucault famously put it, akin to eating an indigestible meal (Foucault, 2004: 78). This dissertation's second general field of interest is, thus, investigating theoretically ways in which the state can be thought of and conceptualized within a particular spatial and temporal context: Ecuador between 2008 and 2012. In this sense this dissertation is in equal parts, a theoretical and an empirically 
interpretative project whose objectives are to contribute original knowledge at both levels.

\subsection{Research Questions and Arguments}

This dissertation is concerned both, theoretically and empirically, with the constitution and reproduction of the Ecuadorian state between 2008 and 2012. In this sense, the main organizing question in which this dissertation is rooted: how has the Ecuadorian state reproduced and rearticulated itself following neoliberalism? Given the objectives of the thesis and its thematic interests (narratives, participation and power), this question can be methodologically divided into four specific parts: First, how can "the state" be conceptualized theoretically within the specific historical configuration mentioned above (Ecuador, 2008-2012)? Second, what are the main narratives developed by the state in the process of its post-neoliberal rearticulation since 2008? Third, how is participatory planning governed and what is its relationship to state formation? And finally, what power modalities has the Ecuadorian state exercised in the field of participation?

I answer these questions through the following arguments: First, this dissertation's main theoretical argument is that the state reproduces itself partly by creating spaces where it can legitimately intervene in society. This process can be understood by looking at three complementary and interrelated developments: a. The formation of narratives about the state seeking to legitimize its presence in society; b. Governmental practices: the ways in which the state apprehends, organizes, distributes and ultimately creates specific fields of intervention; c. The 
exercise of different and complementary modalities of power, including governmental and disciplinary forms of power. I call the combined operation and functioning of these elements a "governmental regime."

Following this theoretical, overarching argument, I contend, that the Ecuadorian state has reconfigured its governmental capacities through a combination of modern techniques of power rooted in a technocratic, knowledgebased form of government and disciplinary techniques of rule based on the correction and reformation of particular populations, mainly the indigenous movement represented by CONAIE. The dissertation contends that on the one hand there is a governmental effort to "technify" and depoliticize participation in order to make it more governable; and second, popular participation that steps out of the boundaries of the governmental ethos of the state is met with disciplinary acts. Finally, it will be argued that the Ecuadorian state can be characterized as a disciplinary, modernizing neodevelopmental state.

This dissertation's contributions are both theoretical and empirical. At the level of theory, it proposes a novel use of the theoretical tools of the governmentality school. Typically applied to forms of rule beyond the state (Miller and Rose 1992) governmentality, I argue, can be particularly useful in investigating techniques of state formation that are not rooted in legal regulations, prohibitions, coercion or other means generally associated with the state. States with a technocratic dimension, in particular, engage in forms of regulation that are mundane, indirect and rooted in techniques, expert knowledge, manuals, statistics,

${ }^{2}$ I first saw this term being used in Mitchel Deans's "Governmentality: Power and Rule in Modern Society" (1999). 
and/or visual representations of populations; they also rely on the self-regulation of agents. Similarly, the consequences of governmental interventions may be different from those anticipated by the "good will" of governmental officials. Governmentality focuses precisely on the unintended consequences of the application of methodologies, manuals, calculations and so on (cf. Li, 2007; see Chapter Two). In the case of the construction of the PNBV, I show that the government officials I interviewed were genuinely seeking to foster participation, but in the end what was discovered is that the unintended consequences of their methodologies had a depoliticizing effect on the outcomes of the PNBV workshops.

Empirically, I have conducted primary research on the development of the PNBV. This is the first in-depth study of participatory planning in Ecuador since 2008 and the first to look at the relationship between state formation and its relationship to governmental regimes. This examination focuses on narratives of state formation and the way they are related to participation and state-formation. This work looks at how the state brings together disparate state narratives, mainly developmentalist-modernizing and SK/BV in order to legitimize its presence in society. The incorporation of indigenous narratives (i.e. Sumak Kawsay narratives), it will be shown, contributes to the efforts at depoliticizing, de-radicalizing indigenous peoples' participation. Finally, participation is also looked at from the perspective of social protest. Specifically, this work shows that disciplinary practices and tactics are employed to respond to social protest and acts of resistance against aspects of state policy. Both of these components should shed light on the relationship between state formation and participation. 
Thus, this dissertation opens a new line of research that is concerned with understanding how participatory planning at the level of the state (this has been done at the level of, for instance, NGOs - see Tania Murray Li, 2007 or James Ferguson, 1994) is related to politics at the level of organized civil society. Future research questions may include: what are the real possibilities for the development of participatory democracy in consolidated, technocratic states? What participatory planning techniques are more conducive to forms of participation that are capable of challenging the state-sponsored status quo?

Before continuing to the methodological section of the dissertation, I should note that this dissertation is not about participatory democracy as such. This work investigates government through participation, not the other way around. It does not seek, furthermore, to answer questions about the state of popular participation in Ecuador as such. Neither does it hope to evaluate the concrete experiences of specific civil society organizations like NGOs or even the indigenous movement. This dissertation is about the government of the state and even though it recognizes that the state cannot be understood in isolation from society, it attempts to view state-society relations from the vantage point of the state (cf. Scott, 1998), or more specifically, its government. Furthermore, this dissertation does not argue that the state has successfully depoliticized society. The main implications of this dissertation's arguments are that there is an anti-political ethos in the construction of governmental interventions in society, particularly in the field of participation. However, as I argue in Chapter Two, I regard the state, as a project, not an 
accomplishment, and its actions as being always susceptible to challenges, transformations and setbacks.

\subsection{Methodological Considerations}

Before entering into the details of how to methodologically answer the questions posed in this dissertation, it would be useful to make a few remarks about its central concepts and assumptions. First, it should be noted that most theoretical discussions about how to define central terms like "government," "power," the "state" and "politicization" are elaborated in detail in Chapter Two. Thus, here I will simply make a number of necessary clarifications. One of my central methodological-theoretical points of departure is the attempt to avoid any reification or anthropomorphization of the state. The state is neither a concrete nor discrete entity, it is mainly a set of relations rooted in ideational and material factors (see Chapters Two and Three). Thus, even though I use the term "the state," I acknowledge its complex, dynamic and relationally based ontology. For the purposes of pragmatic simplicity, I employ, simply the term "the state." Second, when I mention that the state "does," "knows," or "acts" in certain ways, I am not implying that these are equivalent to humans' thinking, acting or doing. Again for simplicity's sake, I recur to this terminology but assume that states do not wilfully act or think. As I make clear in Chapter Two, one of my central theoretical contentions is that the state is not the overarching, rational centre from which power within a country emanates; states have no will of their own and their actions are not analogous to individual acts of human beings. Similarly, I contend that one 
must be theoretically wary about assigning states rational-choice type faculties. States, this dissertation argues, act within various forms of rationalities and mentalities and are not rational beings operating through an internalized, unitary sense of will operating through a singular rationality.

And finally, the period since the election of President Rafael Correa is, in many ways, unprecedented and that is one of the reasons this dissertation is interested in investigating it (see Chapter Three). Thus, I refer to the process of state construction since 2008, or more appropriately, its form as the "Correista state." This should not be interpreted as a statement about specific aspects of the role President Correa has played in this process. It does acknowledge, however, that President Correa has indeed been a central figure in the development of the state since 2008.

\subsection{Broader Methodological Tradition: Interpretivism}

Interpretivism is rooted in the Socratic tradition of critical thought that sees the role of intellectual endeavours, including academic research, is to problematize issues that may be conceived as accepted truths. Interpretation seeks to understand social realities, not necessarily explain them in a deductive-nomological sense (cf. Przeworski and Teune, 1982; Wendt, 1998). Interpretation is, in a way, a thick description (Geertz, 1973, 1980) of social relations that take place and unfold in fields of socially constructed knowledges, realities and forms of representation (cf. Rojas, 2002). An interpretivist approach is interested in giving accounts of objects of knowledge in the social world that are not necessarily measureable like, for 
example, governmental regimes, power modalities, or state narratives (Heller, 2008). This is why interpretivism's social ontology can be referred to as a social constructivist one. Instead of eschewing objects of knowledge that lack a measurable dimension, interpretivists like Arturo Escobar (1995), argue that in order to understand the reproduction of social systems and forms of rule, government and domination, one must consider the importance of non-measurable objects and subjects in the constitution of reality (also see Lemke, 2007).

A useful, albeit simplified, description of this approach is given by Alexander Wendt (1998: 109-110) in the following way:

When a small child asks her parent, 'what's that?', she might be satisfied with the response, 'a dog'. That answer doesn't seem to involve much in the way of 'explanation'. If the child persists and asks 'what's a dog?', the parent may say 'man's best friend'. This too seems descriptive, since it doesn't seem to do more than point to the role that dogs play in human society, although it also sends the implicit message to the child that dogs are not dangerous. Yet, the English language permits an explanatory interpretation of the parent's answer as well: it would be equally valid to say that the parent was 'explaining' the role of dogs in society, and 'explaining' the fact that dogs are not dangerous by reference to their being our friends. Neither of these explanations is causal. Semantics perhaps, but it suggests that already at this very simple level the answers to what-questions might not be purely or unambiguously descriptive, but have varying degrees of explanatory content. 
The social ontology of interpretivism, thus, leads the researcher to ask how and what questions rather than 'why' questions. This dissertation's research questions (see above) follow these principles.

The selection of an intepretivist stance responds to a basic methodological concern with research questions. The relevance of a research method is directly related to the type of questions the researcher is interested in. Questions originate from a dialectical process involving experience, theory and reflection. From this dialectical process assumptions and positions about research objectives are adopted. In particular, ontological assumptions about what is real and what constitutive elements of social reality must be highlighted are made. Since this dissertation is interested in a relational "entity" like the state and its regimes of government, it is fundamental to consider how it can be studied through the formulation of pertinent methodological building blocks that enable the researcher to enter into contact with those relations and fields of knowledge. Below I explore the basic building blocks of this dissertation's methodological approach.

\subsection{A Historical Approach: Genealogy}

The study of governmentality as Mitchell Dean (1999) argues, is rooted in history. (Dean, 1999: 50). This work therefore, looks at the Ecuadorian state as being historically rooted. For this reason Chapter Three develops a detailed historical contextualization of the Ecuadorian state and its relations with indigenous peoples. But how is a "historical approach" conceptualized and organized? One of the main guiding principles of historical thinking this dissertation employs is 
Foucault's concept of genealogy. It should be noted, before explaining this dissertation's use of the concept, that the use of genealogy need not entail accepting all of its epistemological implications. Clearly, some aspects about "reality" in this dissertation are assumed, not put into question.

Genealogical research entails looking at moments of rupture, and importantly, putting into question accepted historical truths, concepts and histories. A Foucauldian genealogical approach shows the contingency of discursive practices and 'realities' (Milliken, 1999; Walters, 2012: Ch. 4). Thus, instead of assuming the state, this work problematizes it and questions its status as a form of truth, as a social "reality." This is not to argue that the state is not a reality; it is, but one that unfolds on a regular basis, a reality that is contingent and rooted in historical contexts (cf. De la Cadena, 2007). Genealogy also entails inquiring into the marginal discourses and subjects of a social order. This is partly what is meant by ruptures: instances in which dominant forms of representation are challenged by marginal discourses and forms of representation (cf. Rojas, 2002). Thus, Chapter Three looks not only at the state and its moments of crises, but at indigenous populations and their acts of resistance. As marginalized populations indigenous peoples have consistently ruptured the stability of hegemonic interpretations of reality and that is the primary reason Chapter Three develops a detailed account of the historical context in which they have engaged with the state: colonialism.

Genealogy enables us not only to place the act of government in a historical perspective but also to problematize the emergence of fields of governmental intervention. As Dean (1999) shows, fields like health, the economy and so on are 
not spaces that pre-exist governmental practices, they are constituted by/through them. In the case of Ecuador I problematize how the state has constituted (not unproblematically or without vicissitudes, of course) a space of intervention called "participation." Guided by the theoretical precepts of a governmentality approach I analyze in Chapter Six the ways in which various forms of knowledge about populations and techniques of government help constitute fields of intervention where none existed before. I show, as mentioned before, that one of the ways in which the state reproduces itself is precisely by creating spaces where it can legitimately intervene.

Finally, genealogy is useful in the study of power relations. One of the central contentions of this dissertation is that the current state is characterized by the exercise of several forms of power, one of which is government (see Chapter Two). As discussed in Chapter Two, following a governmentality studies approach, I regard 'government' as a modality of power (which is in itself plural). The other is discipline. Government as a form of power is understood in this dissertation as a process, not an accomplished fact. This work contends that the Correista state is historically linked to a process that seeks to governmentalize aspects of its relations with society: in other words, it seeks to construct self-reliant, autonomous subjects capable of governing themselves and thus capable of being governed at a distance. Perhaps it should be noted that this is a specifically liberal form of government. However, the reason it is able to do so is because of the particular historical juncture in which it developed (the post-neoliberal, post Constituent Assembly period). The other form, discipline is also viewed historically from the perspective of colonial 
relations. The dissertation interprets acts of discipline by the state as emerging within a colonial matrix of interpretation of what, for instance, it means to be backward, anachronic, ignorant and so on (see Chapters 2 and 7). Finally, genealogy views power relationally. This means that power cannot be understood by looking at a (static) source out of which power emanates whether it is the market, the church, the state, a ministry, a law, etc.

In this respect, an important notion that is often forgotten or neglected about the work of Foucault (see for instance Walsh, 2007; Stoller, 1995) is that genealogy, seeks to rescue "subjected knowledges" that have been silenced through the force of a hegemonic field of interpretation. In his work Society Must be Defended, Foucault clearly states the importance of unveiling and "giving" voice to subjugated knowledges and subjectivities (2000: 21-22). Genealogy is particularly useful in localizing micro struggles, and making visible hidden identities, voices, memories, and knowledges. My research on the 2013-2017 PNBV workshops and the micro spaces of government reflects this methodological concern.

\subsection{Reflexivity}

The second broad methodological building block of this dissertation is reflexivity. Reflexivity entails, in simple terms, a mutually constitutive relationship between the ontology of a research project and its epistemology. Put differently, part of what one researches is dictated by the theoretical stance one adopts and the assumptions about what ought to be known and how. In the case of this dissertation, for example, I look at various aspects of government like acts of problematization, 
the use of maps, and calculations partly because those are elements stressed by a governmentality approach. At the same time however, governmentality has been chosen because preliminary research indicated that the Correista state governs through some of the practices elucidated by govermentality studies. Thus, there is a reflexive relationship between what the researcher studies and the theory that makes those objects of study visible.

\subsection{Methodological Tools}

The method being followed by this dissertation is an interpretative case study (cf. Lijphart, 1971). A case study is a research method defined by its in-depth look at one particular case. In contrast to the comparative method, the case study is advantageous in that, as Arendt Lijphart (1971: 691) notes, "by focusing on a single case, that case can be intensively examined even when the research resources at the investigator's disposal are relatively limited." The case study method within the interpretive tradition of authors such as Clifford Geertz (1979) involves interaction with actors, participation in the activities which one is interested in and the analysis of the historicity of those forums. Following aspects of Geertz's approach to ethnography (Ibid.), the method espoused here is interested in providing a thick

description of the processes of state formation. Accordingly, two specific methodological tools were employed in the research of this dissertation, aside from the historical approach already mentioned: first, participatory observation of the PNBV workshops organized by SENPLADES and second, a discourse or narratives analysis of narratives of state formation and power modalities. 
Participant observation entailed being present and participating in PNBV workshops. It also involved conducting semi-structured (some questions are planned others emerge during the process itself) and structured (spontaneous conversations as well as unplanned interviews) interviews (Heller, 2008) with PNBV workshop participants. The objective of these techniques is to access the worlds of research "subjects." To paraphrase Monica Heller (2008: 257) this process allows the researcher partial entries into the discursive fields and practices that inform what people do and why they do it. Through observation and interviews, therefore, one can attempt to understand what were the outcomes of the engagements between governmental officials and workshop participants during PNBV workshops. The method for selecting the type of workshops to be researched, whom to interview and what to analyze during workshops was largely dictated by theory (governmentality studies). The theoretical framework of this thesis pays particular attention to the relationship of politics and government (see Chapter Two); it also pays attention to power from a genealogical stance; finally, it stresses forms of government beyond coercion and outright regulation.

For that reason I selected regional workshops designed to "identify key problems to develop a national and regional vision [of social problems] in the long term" (SENPLADES, PNBV 2013-2017, 2014: 37). The "regional" scope of the workshops meant that different regional perspectives in a highly diverse country such as Ecuador would be captured. The PNBV regional workshops included a total of 240 participants. I attended and/or obtained information from $13^{3}$ workshops.

\footnotetext{
${ }^{3}$ See Appendix 2
} 
The total number of participants in the workshops I attended was no less than 85.4 I explain the specific methodology SENPLADES itself used during workshops in Chapter Six, but it would be useful for my purposes here to note that workshops were composed of three distinct sections: the introductory talks given by SENPLADES's officials, working-tables discussions in which participants from each region discussed issues presented by SENPLADES (which originated in other participatory planning workshops); third and finally, a plenary session in which the content of table discussions was systematized by SENPLADES's personnel. My attendance to the workshops was organized through coordination with officials at SENPLADES some of whom I also interviewed as part of my research. Because of considerations regarding risk and ethics requirements, all of the people I interviewed and their institutions and institutional affiliations, shall remain anonymous.

The methodological posture I assumed during workshops was to follow the same regime that actual participants followed during workshops. I took notes during presentations by SENPLADES, participated (although not as actively as actual participants) in working-tables and listened to plenary sessions. In addition I interviewed SENPLADES officials and workshop participants. In total, including interviews conducted outside workshops I conducted 28 interviews. In addition, and guided by governmentality criteria, I collected data about the type of materials used, the methodology employed by SENPLADES during workshops and the time distribution followed (how long each session lasted, how time was distributed

\footnotetext{
${ }^{4}$ This is an estimate because workshop participants were difficult to count. Many were late, others entered and exited the sessions while others only stayed for some of the duration workshops.
} 
between the different portions of the workshop) by SENPLADES during workshops. Moreover, I paid close attention to the interaction between participants and state officials (SENPLADES experts). Finally the issue of diversity was important as well: I noted whether participants were men or women, indigenous, Afroecuadorian, white and/or mestizo.

Because the final results of these workshops (workshops took place between 2011 and 2012) were only published after much of this work had been written (in 2013 and 2014), I conducted a content analysis of the previous PNBVs: 2007-2009 and $2010-2013^{5}$ in order to establish how the logic of participatory planning is actually expressed in PNBVs. Notwithstanding this obstacle, it is in the process of research during workshops themselves that the governmentalized logic of participation was observed. The content of workshops is, I contend, sufficient to support this dissertation's arguments about the government of participation. The theoretical tools provided in Chapter Two also guide my analysis of the PNBVs. I look at the ways in which PNBVs, particularly in the period 2009-2013 represent peoples, issues and problems. I identify how and what the implications are of the way in which SENPLADES (the agency that drafts the PNBV) problematizes issues and creates knowledge about populations. Thus I analyze maps, calculations, the representation of statistics, among other things, to elaborate on the development and construction of fields of governmental intervention (cf. Li, 2007; Dean, 1999). In sum this work looks at PNBVs to disclose how governments create or modify fields of intervention in society

\footnotetext{
5 Ecuador has had a total of three PNBVs: 2007-2009, 2009-2013 and 2013-2017.
} 


\subsection{The Analysis of Narratives and Representations}

Like in the previous section, the specific methodological choices for the study of the state are guided, in part, by theory. In Chapter Two I develop a definition of the state, following Joel Migdal (2001) as well as Foucault (and to some degree Weber) that conceives of the state as being composed of narratives (images) about its legitimacy as well as practices of intervention. The state generates its own regimes of representation, its own images of what it is and how it ought to be perceived. Thus, from a methodological point of view it is imperative to capture how the process of weaving together different narratives about the state unfolds. To do so I employed a critical discourse/narratives analysis of how the state is constructed in narratives and representation. Specifically, this method involves analyzing systems of meaning, and hierarchies of knowledges and representation. It also involves looking at how different narratives, like the Sumak Kawsay/Buen Vivir, or developmentalist narratives are employed to generate specific interpretations about the state and its character. A good example of this approach is Arturo Escobar's analysis of development in the post-War period (Escobar, 1995). In the case of this dissertation the materials chosen for its analysis of narratives and content analysis are President Correa's Weekly Presidential Reports (WPRs). These are weekly radio and television broadcasts where the President discusses issues of national interest (a detailed description of WPRs is provided in Chapter Five). However, I also look at government documents, governmental media releases, governmental ads and publicity campaigns as well as key specific figures of state policy to evaluate how 
narratives and practices come together.

Similarly, I employ a critical analysis of narratives to address the interaction between the state and indigenous populations in the context of participatory engagements beyond the PNBV. This is an important tool because a narratives approach (also called a discourse analysis) allows the researcher to capture how different identities are portrayed in different circumstances and to see

how internally to a text [or oral expression], the poles of oppositions which it privileges and the 'realities' it thereby makes basic or original can be reversed and displaced, thereby producing other 'truths.' The 'orthodox meanings' of a discourse in such cases are shown to lack stable foundations claimed for them, indicating that these are imposed readings which could have been different (Milliken, 1999: 242-243).

Hence, in Chapter Seven I analyze WPRs and governmental reactions to indigenous protests to unearth the series of meanings attached to indigenous peoples' mobilizations and participation. In this particular instance, namely indigenous mobilizations, I also engaged in participant observation and conducted interviews. I attended, for example, the largest indigenous mobilization since 2006. To capture the disciplinary effect of power I also interviewed a number of indigenous leaders and protesters between 2010 and 2012. I chose my interviewees according to the following criteria: being members of CONAIE or another organized indigenous group; to have been involved in participatory engagements with the state and/or in policy-making within the state and who have had a recognized trajectory in indigenous organizations. My interviews mainly focused on the 
question of participation, public-policy making and the relationship between indigenous peoples and the state.

\subsection{The Organization of this Work}

This dissertation has been organized in eight chapters. Each chapter contains three interrelated and co-constitutive building blocks: the first is historical, the second is theoretical, and the third is empirical. It is important to specify the logical progression that this dissertation's arguments follow in relation to these building blocks. Specifically it is worth stressing that the interrelationship of these basic parts is what gives this dissertation its unity, integration and cohesiveness. Overall, the logical structure of the dissertation is as follows: after establishing a brief context, its research questions and arguments the dissertation develops the historical context within which the case of Ecuador can be understood. The second building block is composed of two constitutive parts, first debating the literature about the state in Ecuador and second, presenting my own theoretical alternatives. These two first building blocks are interconnected in a variety of ways. First, because the theoretical approach espoused here is rooted in historical contextualization. In this sense, the theoretical block of this dissertation could not be made sense of without the historical contextualization that makes the particular choice of theory pertinent. The third and final building block of this work, the empirical component, closes the circle of interpretation. It provides not only evidence (evidence understood, of course, from the perspective of intepretivism) of the linkages between the historical and the theoretical components of the 
dissertation. The evidence provided can only be understood as an expression of a historically-rooted present and its logical progression, its main themes and objects of analysis, through the lens of the theoretical portion of the thesis. The chapters below, therefore, have been organized to fit this logical construct. In turn I provide a brief sketch of their contents.

Chapter Two has two objectives, first to review the most pertinent arguments about the contemporary Ecuadorian state and second, to provide the theoretical contributions of this dissertation. Chapter Two begins with a review of the debates about the contemporary Ecuadorian state. It focuses mainly on Ecuadorianist literature and on specific arguments; however, it is conceptually organized in a way that stresses the broader intellectual traditions and theories that inform the Ecuadorianist literature. In this sense the Chapter divides these traditions and arguments along three broad classifications: insitutionalist, structuralist and culturalist approaches (cf. Lichbach and Zukerman, 1997). In this sense the Chapter assesses how these intellectual sources have informed and shaped the Ecuadorianist literature about the state. Moreover, Chapter Two stresses the contributions and the importance of these traditions and arguments but also points out several of their weaknesses thus establishing the need for a different alternative.

Such an alternative is provided in the second section of Chapter Two. Before briefly sketching out the Chapter it would be useful to stress that theoretical content of Chapter Two is both a framework for understanding the information presented in subsequent chapters and a theoretical argument in itself. The title of this section of 
the Chapter, "Theoretical Contributions," seeks to reflect precisely this point. As mentioned earlier, this dissertation means to contribute to the theoretical literature about the state, particularly from the perspective of governmentality and its possible applications to states such as Ecuador's.

The theoretical section of Chapter Two is mainly devoted to first, "describing" governmentality, second to developing a theoretical argument about the pertinence of its use to analyze the state. Chapter Two also stresses, however, the importance of avoiding excessive reliance on a single theoretical source. Thus, I complement it with Joel Migdal's theory of the state as well as a series of decolonial/postcolonial reflections about indigenous people's agency and forms of resistance under postcolonial regimes. The overall theoretical argument seeks to link the concept of governmentality to that of the state. It stresses the governmental ethos of parts of the Ecuadorian state. An important aspect of this discussion is power. Power, as has been said, is an integral concept in this dissertation. In a way it could be said that this work is about power. Thus, Chapter Two analyzes different modalities of state power and how these can be integrated into an analysis of. The work of Foucault is crucial in the development of this section. Along these lines, it would be worth mentioning that the theoretical contributions of this dissertation have been greatly influenced by the writings of Mitchell Dean (e.g. 1999), Tanya Murray Li (e.g. 2007a, 2007b), James Ferguson (1994) and William Walters (2007, 2012). While the bibliographic references for the construction of Chapter Two go well beyond the contributions of these authors, it is important to acknowledge their 
influence in the development of this dissertation's own use of governmentality and the way in which it is "applied" in Chapters Four, Five and Six.

Chapter Three provides a detailed historical account of the Ecuadorian state between 1830, when the Republic gained independence, until 2006 when current President Rafael Correa was elected. This chapter represents an effort to contextualize the different histories of the Ecuadorian state. It highlights some of the Weberian influences of this dissertation, particularly as much of the chapter could be describes as historical sociology of the state. At the same time however, it stresses its genealogical and governmentality roots by focusing on marginalized voices and knowledges and the constructed character of state-society relations. This section advances the following argument: that the Ecuadorian state, understood from the perspective of its ability to penetrate society and establish its presence in its territory has been qualitatively different from that of the Correista period. The objective of this argumentative stance is to stress the pertinence of analyzing the Correista state as a case study for this dissertation. To illustrate the argument about state's relative weaknesses, Chapter Three shows, that the state in Ecuador has been riddled with political, social and economic crises. Thus, I trace the political history of the state and stress the constant recurrence of political crises and the ensuing changes in the formal institutions of the state that this has generated; Ecuador, for example, has had twenty constitutions since 1830. Finally, the chapter contextualizes the years leading up to and the period during which the current Constitution was conceived, discussed, drafted and enacted. 
The second argumentative line of Chapter Three traces some of the history of state-society relations, particularly with the indigenous movement. While the objective of the section is to stress that the wider context in which the state relates to indigenous populations is that of coloniality, the angle from which it develops its claims is through an emphasis on agency and the capacity of the indigenous movement to mobilize and confront colonialist practices coming from the state (and society). This section of the chapter could also be read as a confirmation that the state can only be understood as part of social relations, not as an autonomous entity. Chapter Three ends, from a historical point of view, exactly where Chapter Four begins. Chapter Three ends by a short analysis of the pre-Constituent Assembly period. It shows the politicized environment of social participation between 2006 and 2008. Chapter Three also presents part of the historical evidence for affirming that the Correista state between 2006 and 2012 was characterized by two distinct periods: the pre- and the post-Constituent Assembly periods.

The following chapters build from the previous building blocks. Specifically, they look at the three components of the state: narratives, practices and power. Consequently, Chapter Four focuses on the different sources of state narratives, particularly it sets its interest on how narratives about development and modernization unfold, what their constitutive elements are and how they are turned into practice. The chapter, for example, focuses on how the notion of modernization in Correismo is linked to a technocratic bureaucracy that in some senses resembles the Weberian-type bureaucratic apparatus that Peter Evans (1995) associates with developmental states. This chapter also pays attention to how narratives that are 
fundamentally "opposed" or different are brought together under the image of the state. Specifically I analyze, through the concept of reverse-autoethnography (developed in Chapter Three) how the state employs the symbols, language and representations of indigenous peoples' radical narrative of Sumak Kawsay. Once processed through the governmental apparatus, the Chapter shows, the Sumak Kawsay/Buen Vivir narrative is stripped of its radical content thus becoming integrated into the "anti-politics machine" (Ferguson, 1994) of governmental regimes.

Chapter Five and 6 develop an understanding of how a specific governmental regime unfolds. They begin by focusing on more macro level factors like the development of national statistics, maps, the special representation of the state and its peoples and the creation of a variety of knowledges about the country. Chapter Five in particular focuses on SENPLADES, its work and its technocratic and governmental ethos. It show how it constructs fields of governmental intervention and how information is used and distributed in the effort to bring the state to places it had not been before. Chapter Five also analyses the contents of the 2010-2013 PNBV and contrasts it with the politicized narratives of Sumak Kawsay/Buen Vivir and concludes, as did Chapter Four, that as SK//BV narratives enter the governmental machinery their radical contents are made invisible. Finally Chapter Five shows the different ways in which participatory citizenship develops, how it is portrayed and the different mechanisms that the state uses to foster it. All of these manifestations of state-level participation have in common their anti-political and/or de-radicalized contents. 
Chapter Six, on the other hand, takes the analysis of governmental regimes and applies it to the micro level, specifically to the participatory engagements between state and civil society for the construction of the PNBV 2013-2017. The focus of the Chapter is on a series of workshops discussed above where I conducted primary research between 2011 and 2012. The aim of the Chapter is to elucidate what the effects of these workshops were on the content of participants' demands of and stances towards the state. The chapter pays special attention to how SENPLADES's officials managed and processed the information provided and expressed by participants. The focus of the chapter is not on individuals working for SENPLADES but on techniques and their roles as experts. One of the revealing conclusions of the chapter is that the government of participation can have unintended consequences and that power, as Foucault insisted, cannot be reduced to those who "possess it." The SENPLADES personnel I encountered expressed to me their genuine desire to foster participation, and during workshops their work reflected this interest. However, the techniques, knowledges and methods employed to do so and, particularly, the effects that they had on the content of participatory engagement go beyond the intentions and diligent work of those officials. That is not to say, however, that purposeful acts by government officials are unimportant. The point is that rendering participation technical means that participation becomes de-politicized independently of whether officials intended it to be that way or not. Chapter Seven continues with the theme of participation but focuses its attention on more conflictive arenas. It specifically deals with the relationship between indigenous peoples and the state in contentious situations. The chapter's main 
argument is that participation outside of the state's regime of improvement (modernizing neo-developmentalism) is met with acts of discipline. More generally the chapter posits that the relationship between state and indigenous organizations, particularly CONAIE, can be understood through the lens of disciplinary power. Discipline as Chapter Two argues is about the reformation and correction of populations. In contrast to authoritarianism, discipline does not exclude or exterminate (cf. Hindess, 1998) populations deemed incorrigible. Discipline seeks to transform individuals through controlled and/or limited periods of coercion, punishment, shaming and so on. Chapter Seven shoes that one way in which the state seeks to discipline indigenous populations is through acts of shaming (calling them backward and ignorant) that can only be understood within the context of colonial practices and the colonial and post-colonial history of Ecuador.

Finally, Chapter Eight reviews the central points raised in the dissertation. It highlights its main strengths and some of its problems. It touches on, for instance, the importance of disclosing the act of government as a process in need of explanation. It stresses the ways in which governmental interventions in society work and how the government of populations relies on a multifarious series of techniques, power resources, mentalities and narratives. Moreover, it reveals the ways in which its research and theoretical contributions could be taken further and how this line of research offers interesting opportunities for the discussion of the state, government and participation in a broader Latin American context. 


\section{CHAPTER TWO}

\section{THE LITERATURE AND THEORETICAL CONTRIBUTIONS: GOVERNMENTALITY, REGIMES OF GOVERNMENT AND THE STATE}

\subsection{The Literature Situating this Work's Main Arguments and Debates}

This section discusses the debates that set the stage and help contextualize this dissertation's main arguments. More specifically, I discuss the most important debates, interpretations and theoretical approaches to studying the contemporary Ecuadorian state within the Ecuadorianist literature. Such a discussion, however, would be incomplete without referring to some of the larger theoretical discussions that inform those debates in the first place. Hence, the following sections address the main debates around the state in Ecuador between 2008 and 2012 as well as reviewing some of the intellectual traditions that inform those debates. I will organize my discussion here around the following thesis: the most prevalent and dominant interpretations of the state and the government of participation are derived from variants of institutionalism (mainly democratic institutionalism and historical institutionalism), structuralism (including historical structuralism and Marxist approaches) and culturalist approaches (mainly theories on populism). I also contend that the main source of debate about the state is the question "what type of state is the Correista state"? And also, what are the elements of state behaviour one ought to look at?

\subsection{Main Debates and Theoretical Sources in the Ecuadorianist Literature Institutionalism}


I would argue that some of the most relevant interpretations of the state revolve around the question of its institutionalization, particularly its democratic institutions. The basic formulation of much of what I will refer to here, in a broad sense, as the "institutionalist" literature, regards both state power as well state strength in relation to the levels of institutionalization of its democratic institutions. A merit of these interpretations is that both theoretically and empirically they look at the quality of liberal democratic development, including the independence between state powers and the rights of individuals and communities. Understandably, state interventions in society are evaluated based on the respect for the law and institutional norms. Some notable authors within this tradition include: Simón Pachano (2007, 2011, 2013), Felipe Burbano de Lara (2003), Santiago Basabe (2009), Pablo Andrade (cf. 2008; 2010), Cesar Montúfar (2014 unpublished; referenced with permission of the author).

Arguably, the theoretical tradition that institutionalists like Simon Pachano, for example, follow is a continuation, albeit with differences, of the "transitions" literature (and their Weberian influences) of the 1970s and 1980s (see for example Linz and Stepan, 1996; Mainwaring, 1989; O’Donnell, 1973, 1986a, 1986b, 2007; Valenzuela, 1985). Their line of argumentation establishes close linkages between understanding processes of state formation - or at least explaining state behaviour, and its politico-electoral-procedural systems and the degree of respect given to them by political agents, most notably political elites. Like in the "transitions" literature some of the most important aspects of the state are explained through an analysis of the institutionalization of democratic life, including the degree of party 
development, as for example in in Mariano Torcal's and Scott Mainwaring's analysis of political parties' levels of institutionalization (Torcal and Mainwaring, 2005) or Catharine Conaghan's analysis of the party system in Ecuador (Conaghan, 1985, 1987).

In terms of "institutionalist" analysis of the Ecuadorian state one finds two main concerns: first whether the state is sufficiently democratic, based on a minimalist approach to defining democracy, and whether state institutions, including those concerned with participation, are sufficiently institutionalized for democratic development to take place. Clearly, both of these issues are interrelated, however, the first issue is largely linked to the question of state power, while the second, to whether state actors adhere to the formal rules of the political and legal systems of the state. Good examples of this approach can be seen in the works of Basabe (2011), Pachano (2010), Pachano and Garcia (2013) and Montúfar (2007, 2008, 2014 - unpublished), and to a certain degree, Conaghan and de la Torre (2008), and Conaghan $(1985,1987,1994)$.

To analyze some of these arguments in detail, a good place to start would be Pachano's and Garcia's (2013) work on the quality of democracy in Ecuador under Correa as well as Pachano's work on state power and institutions (2009). These works are explicit in showing the analytical variables used to measure democratic development. Pachano and Garcia, for example, present the following variables: "a) The rule of law; b) electoral accountability; c) institutional accountability; d) participation; e) competition; f) capacity of response; g) respect to for rights and freedoms; h) social and economic solidarity-equality" (Pachano and Garcia, 2013: 2). 
All of these variables, even "h," which are not at first glance a question of formal institutions only, are derived from a concept of democracy "understood strictly as a political regime, that is, as a conglomerate of rules, institutions and procedures established to make effective the participation and public debate, as well as select and control public power" (Ibid.). Through this approach Pachano and Garcia conclude that Ecuador's is a hybrid system: not democratic, but not authoritarian (reminiscent of O'Donnell's dictablandas). Put differently, some of the variables used to measure the political system, like electoral accountability, score relatively high (3.91/4.5) while others, like the rule of law $(2.47 / 4.5)$, relatively low (Pachano and Garcia, 2012: 23). Moreover, a conspicuous element in this approach is the formalistic understanding of power as institutional power (or the power to trespass it). Reflecting the liberal tradition, power is understood in juridical terms. Notwithstanding the positive contributions made by this type of approach, it becomes clear that the entire enterprise to measure the performance of the political system is entirely contingent upon the formal architecture of state institutions (more on this below).

A similar approach is adopted by Andre Coelho et al. (Coelho et el., 2010). Specifically, Coehlo and his colleagues evaluate state reforms in the area of participatory democracy. Notwithstanding several differences, the authors also consider the central aspect to be measuring the possibilities for participatory democracy to develop in Ecuador, and the constitutional mechanisms designed to enable it. Accordingly, Coelho and his colleagues compare constitutional mechanisms in Ecuador, Bolivia and Venezuela, designed to widen participation. 
They interpret the recent (Bolivia and Ecuador) constitutional changes adopted in these countries as a sign of an expanded form of participation. Moreover, constitutional reform is viewed as evidence that these countries hope to "respond to the crisis of representation that shook the region in the nineteen nineties" (Coehlo et al, 2010: 91). Like in the case of Pachano and Garcia, and Pachano $(2007,2009)$ the entire analysis given by Coelho and his colleagues is contingent upon state and non-state actors' respecting constitutional norms. In their case, however, the focus on institutions is more vulnerable to critique because, it could be argued, the Constitution of Ecuador is not only highly abstract, but has in many respects (like giving rights to nature) no historical precedents or references from which to judge future practices; that is, no way of judging whether the spirit of a constitutional norm (again like giving right to nature or embracing the notion of Sumak Kawsay/Buen Vivir) is being followed in practice by the legal system.

Along similar lines, Ana María Larrea (cf. 2008, 2010) looks at the configuration of the state through its formal organization through the Constitution. Larrea argues that specific historical configurations give rise to different strategies to organize the state. She regards Constitutions as specific representations of different historical configurations. In this sense, Larrea's argument is more along the lines of some Gramscian theorists, like Robert Cox (1981) who regard institutions as representations of a historical configuration of power. However, Larrea's "Gramscian" stance stops there when she stresses the importance of the Constitution, not as a historical configuration, but as a mechanism to bring Ecuador to a post-neoliberal stage in issues like participatory citizenship. Participation, 
Larrea points out, has never been so stressed by any other Constitution in Ecuador's history (Larrea, 2010: 65). As she points out, the new Constitutional paradigm has the power "to invest [participation] with sufficient institutional channels to favour the capacity of collective social organizing and augment the power margins of citizens to ensure respect of their right to participation" (SENPLADES, as cited in Larrea, 2010: 65).

Indeed, as I show in Chapter Four within the current Constitution, references to participation are plentiful. I find Larrea's argument valid insofar as constitutional changes are, no doubt, important indicators of changes in statecraft. Clearly, the institutional apparatuses of a state matter and are in many ways indicative of the type of state that one is trying to understand or make intelligible: repressive laws are, for example, telling signs of a police/authoritarian state. However, as I argue later, there is an important difference between state forms and institutional forms both historically and in theory. Historically, it has been shown, the making and remaking of constitutions in Ecuador signals an important weakness in the ability of constitutional texts to engender actual changes in social and political structures, including processes of statecraft, discrimination against indigenous populations and so on. Moreover, my research suggests that the current state form (understood as a series of actual governmental regimes) is antithetical to a politicized form of participation while its institutional apparatuses, mainly its Constitution, are not. As I argue the next section of this chapter, it is important to make the fundamental distinction between an institutional-juridical form and its form as discourse/practice. The power of an institutional/juridical form must be 
understood beyond and in complement to its formal dictums (i.e. what is written down as laws, regulations, normative bodies and/or Constitutional Articles).

\section{Variants of Structuralism and Political Economy}

Two important works edited by Juan Proaño and Natalia Arcos (2012) on the one hand and by Juan Cuvi et al. (2013) on the other, are perhaps two of the best representations of the debate about the Correista state and participation. The two volumes represent some of the most relevant interpretative tensions about the type of state and its fundamental characteristics. Mostly the Correista state is either denounced for its anti-revolutionary stance and/or praised for the "revolutionary" changes it has undertaken. One side of the polar tension I just mentioned, is represented in the structuralist, neo-marxist approach taken by Mario Unda, one of the contributors of the book edited by Cuvi et al. Unda argues that one of the central tenets of the supporters of the current changes in the state, is the recuperation and the return of the state following the neoliberal era. Unda asks: under what logic is the recuperated state articulated? He looks into Poulanzas and his theory of the "autonomous" state to understand the process of statecraft. Unda argues that state

autonomy, that is, the "specific internal cohesiveness of the juridical-political superstructure," (Unda, 2013: 34) means that the state may at times go against the capitalist class but that it ultimately is an enabling factor for the reproduction and the growth of capital, which, he claims, has been the case under Correismo. From this perspective Unda concludes that the current state must be understood as a "capitalist modernization" project that seeks to modernize, at once and in an 
interrelated fashion the economy and the state. The "Poulanzas thesis" mentioned by Unda, thus hinges on the idea that state interests and ultimately its behaviour can be explained endogenously: the state is partially isolated from "outside" forces and its interests, even if theoretically linked to the reproduction of global capital, are formed from within its own interior. I will address some of the problems with this view later in this chapter.

Along similar lines, critical structuralist Francisco Muñoz argues that a state form can be defined as "the articulation or structuration of the class interests of fractions, factions, economic groups or de facto powers that are intertwined between them and ruled, hegemonically and from a strategy of political domination by the dominant group among them" Muñoz, 2012: 121). From this perspective Muñoz argues that the new state form (under the Correista regime) can be characterized by its linkages to the accumulation of capital through extractivist policies linked to international capital (mainly multinational corporations) as well as oligarchical, monopolistic and oligopolistic groups linked to the neoliberal period. From this Muñoz characterizes the state as a capitalist state (not a socialist one as supporters of the regime and official rhetoric posit) that has rearticulated the state and its relative autonomy but with the intention to serve the process of international capital accumulation (Muñoz, 2012: 124).

Along relatively similar lines Liisa North (2010) analyzes the structural reforms (or lack thereof) undertaken by the Correista state to evaluate not only its fundamental characteristics but also its behaviour. The basic way of understanding the state here is instrumental: the state is captured by an elite that seeks to preserve 
its own interests, or simply, the state protects the interests of those elites without them necessarily being in influential positions within government. This offshoot of Gramscianism is, undoubtedly, an important contribution to analyzing the state. North (2010), for example, shows how the Correista state, despite its rhetorical radicalism has failed to undertake the necessary structural reforms needed to foment real change for the popular sectors of the country. North pays particular attention to the distribution of land and the failure of the state to undertake land reform in any meaningful way as well as its failure to truly revolutionize its educational system. In this sense the state is first captured, and then utilized by elites to protect and/or preserve a structural status quo. These elites need not, it should be noted, be part of the formal bureaucratic apparatus of the state; what matters is that their interests are served by the state.

One question worth positing at this point is, what makes this state any different if it simply is "there" to serve the interests of capital accumulation within a new configuration of geopolitical forces? Clearly, the neoliberal state form also served he interests of transnational capital and represented the class interests of domestic elites. However, Muñoz accepts that there has been a clear and notable transition from a disarticulated state (the neoliberal state) to an interventionist state that has effectively penetrated society, intervened actively in the economy and "acted on behalf of a subject and institutional apparatus that determines and coheres social and political life" (Muñoz, 2012: 124). But what are the fundamental differences in these state forms, besides, of course, questions of size? The "capturing" thesis embraced by the political economy literature hinges on a 
rationalistic ethos attached to both elites and states. The correspondence between state behaviour and elite interests seems too neat and consequential. If that is the case, why are there no more revolts, mobilizations, revolutions or even civil wars? For now, it will suffice to say that the answer perhaps lies precisely in one of the central theses of one of political economy's central figures: Gramsci. I develop this point in more detail below. Not unlike Foucault, Gramsci regarded power beyond its utilitarian dimension. The concept of hegemony precisely does that by problematizing the simple notion that state behaviour and class interests are identical (see Cox, 1983). I will address this issue in more detail below.

\section{The "Populism" Argument}

Besides institutionalist and structuralist theses, a third prominent source of interpretation regarding the Correista state and its power, relates to populism and charismatic leadership, ${ }^{6}$ or more generally to Ecuador's political culture. Carlos de la Torre (e.g. 1997, 2010, 2013) has been a leading figure in this school of thought. De la Torre's principal argument sees the Correista state and its power as being fundamentally linked to the charismatic figure of President Correa and his populist style. De la Torre sees populism as "a strategy to get to power and govern based on a Manichean discourse that polarizes society into two antagonistic camps: the people [el pueblo] against the oligarchy" (De la Torre, 2012: 34). Moreover, De la Torre notes, the populist discourse is embodied by a leader whose charisma allows him/her to incarnate peoples' redemption against all the evils of the nation. The

\footnotetext{
${ }^{6}$ For an interesting discussion regarding general differences in some of these approaches see: Lichbach and Zuckerman, 2007
} 
populist leader, thus, is always in a struggle to defeat the omnipresent enemies of the people (Ibid.). While De la Torre recognizes the importance that technocratic elites have played in the formation of the Correista state (he calls the Correista state a "techno-populist" state), it is the populism thesis that carries the burden of explanation in his analysis of correismo.

The variant of culturalist explanations in which the populist thesis is rooted argues that the relationship between charisma and leadership lies, at least in part, in the populist's appeal to the emotive sentiments of the population, particularly, to cultural manifestations like machismo. In an analysis of former President Abdalá Bucaram, for instance, De la Torre shows how part of the charismatic appeal of Bucaram is rooted in calling upon machista values as essential attributes of his leadership. Bucaram represents the virility of the popular man in Ecuador and incarnates the father figure who will fight for his people even with his own fists if necessary (or primarily). Bucaram appealed to certain cultural sentiments in order to generate the passionate fervour needed to mobilize the masses in his favour (De la Torre, 1997). In an analogous vein, Correa's leadership is linked to his appeal to manhood and virility as ways of constructing a father-figure-style of leadership. And in fact, he on more than one occasion threatened to fist fight his opponents in a display of the manhood that must characterize a leader of his stature. But de la Torre makes one important difference between Bucaram and Correa; he contends that Correa's political style is also rooted in what he calls technocratic populism.

Besides fists, Correa's employs abstract knowledge to appear as the figure capable of not only fighting the enemies of the people, but also lifting them out of 
poverty through knowledge that he possesses, and that only he can apply. De la Torre puts it in the following fashion:

During his [Weekly Presidential Reports] the ritual is repeated. The President sits on a podium from where the professor of the fatherland lectures to all Ecuadorians. He uses PowerPoint presentations to illustrate with numbers and technical data his government's policies. The magisterial lectures given by the President are only interrupted by the applause of the audience, or by the questions that Correa poses to them and that are answered with a 'yes' or a 'no.' In this fashion power is staged: the president-professor stands above an audience that acclaims him but that is unable to engage in critical dialogue with him (De la Torre, 2013: 44).

In sum, the populist argument is rooted in the presence of a charismatic leader and the emotional appeal of his ${ }^{7}$ Manichean rhetoric. Clearly, this line of interpretation largely hinges on the role of the charismatic leader and the representation of state power. And even though De la Torre recognizes the possibility of coexistence of Weber's rational-legal and charismatic forms, his arguments underplay the role of technocratic apparatuses of governmental intervention in the process of state formation, or at least in the governing of the population. Thus, while the technocratic and charismatic appeal of Correa are essential, as the case of former president Abdala Bucaram (President of the Republic, for 6 months in 1996-1997; overthrown by popular mobilizations in

\footnotetext{
${ }^{7}$ I have chosen to leave the masculine form here in order to represent the machista dimension of the populist appeal. This is explained further in this section.
} 
February of 1997) shows, the presence of a strong charismatic, populist leader is not enough to sustain a process of state formation and stable rule of populations. The formation of technocratic governmental regimes as forms of intervention in society has been of crucial importance in the development of the Correista state and in the consolidation of correismo's power of rule. It is important, thus, not to overemphasize the role of charismatic leadership in accounting for the strength of Correismo's governmental rule.

Finally, it should also be said that the analysis based on populism presented above is, in many ways, linked to the insitutionalist arguments discussed earlier. They both emerge from broader Weberian and liberal traditions. Following an insitutionalist line of analysis, the real implications of the populist/charismatic leadership argument are that more often than not, charismatic techniques of power upset the process of democratic institutionalization/consolidation in Ecuador. For example, Catherine Conaghan, along with De la Torre (Conaghan and De la Torre, 2008), argues that there is a symbiotic (my term) relationship between Correa's populism and the "permanent campaign" ${ }^{8}$ style of rule he practices. This relationship debilitates democratic development. Specifically, the authors argue that the use of the permanent campaign can be linked to a polarization of politics and a growing incivility in the political arena ... Campaigning and campaigners is the language of war - opponents are enemies to be vanquished ... As executive power increases during the

\footnotetext{
${ }^{8} \mathrm{~A}$ form of rule based on facing and winning electoral contests on a regular basis. A high number of electoral processes allow incumbents to be perpetually campaigning and taking advantage of the contexts and "liberties" electoral races confer to them.
} 
course of plebiscitary presidencies, the temptation for presidents to abuse the communications apparatus is substantial. In countries where the struggle for democratic accountability is still ongoing, the need to wage the permanent campaign invited an unfair use of government resources and blurs the distinctions between government and partisan activity (Conaghan and De la Torre, 2008: 280-282).

\subsection{Situating the Debate within Broader Intellectual Traditions}

In this section I would like to address the aforementioned debates in a more general sense by linking them to the broader intellectual traditions in which they are rooted. This section addresses, in more detail, the contributions and problems associated with those intellectual traditions and the specific argument mentioned earlier. Thus far, I have shown that it is possible to detect in the Ecuadorianist literature about the state a relatively clear theoretical trifurcation: on the one hand, there is the Weberian, liberal-inspired (in a broad sense) literature about institutions and types of authority; on the other hand, the (again, in a broad sense) structuralists, including Neo-Marxists and political economists who look at the state mainly as a vehicle of class interests or class rule and as being itself "ruled" by larger structural pressures. And finally those that embrace the populism line of argumentation, who, also based on Weber, focus on the role of charismatic rule and its relationship to modern democratic institutions.

The debate about the Ecuadorian state largely hinges on three fundamental concepts: institutions, structures and culture. On the side of institutions the debate 
revolves around whether or not institutions are sufficiently strong. This literature is largely rooted in Weber's contributions to state theorizing, but also in the socialcontract tradition of Locke, and the political writings of Montesquieu. In a more contextualized sense the debate about state institutions in Latin America can be directly linked to the "transitions" literature of the 1970s and 1980s and authors like Guillermo O'Donnell (see O'Donnell, 1973, 1995) and Juan Linz (1978). One of the important contributions of this literature is to argue that in order for any democratic state to consolidate and be stable it ought to develop an adequate set of institutional structures over which basic societal agreements can be sustained. The central idea here is that in order for social, political and economic systems like social democracy to grow and be effective, basic institutionalized agreements must exist. In terms of democracy, it is clear that a basic institutional apparatus that is respected by political players is fundamental.

From a slightly different angle, a more directly Weberian understanding of the state argues that a legal-rational form of authority must be sustained by a strong set of institutional structures, including an effective bureaucratic apparatus (see Evans, 1995). Authority in this sense is understood largely as the degree to which state and non-state actors, especially political elites, adhere to formal/legal/rational institutions of the state. In this sense there is a clear linkage between liberal socialcontract arguments and Weberian ones.

The main difficulties I find with the insitutionalist approach, particularly what I would call "democratic-institutionalism" are threefold: first that the explanatory and/or interpretive capacity of institutions is overemphasized; and 
second, that the normative (over)emphasis on democratic institutions leads to important theoretic-methodological problems; and third, its view of state power. Before I expand of these issues, I should note that while I do propose to overcome some of them through a governmentality-inspired approach, my purpose with this critique is not to downplay the importance of intuitionalist investigations. Works like Pablo Andrade's "Democracy and Political Change in Ecuador" (2010) and Simon Pachano's "Penelope's Plot: Political Processes and Institutions in Ecuador" (2007), among others, are undoubtedly important contributions to understanding the state and political regimes in Ecuador.

Regarding the first point of contention, institutionalists tend to emphasize the lack of adherence, particularly by political elites, including of course state representatives, to the formal rules of the game. This failure to adhere to formal rules compromises the democratic life and the development of a legal-rational form of authority. The main problem with this line of argumentation is that institutions are used to explain the failure of democracy and the failure of democracy is explained by the failure of institutions. In other words, institutions are used as independent and dependent variables to explain weak democracies: institutions do not develop because of the lack of respect for them, and at the same time lack of respect for institutions is understood as a reflection of the weak institutionalization of the state apparatus and its political regime. Besides the evident logical problem, this poses a further difficulty in answering one of the most basic theoretical questions for institutionalism: how do strong institutions develop? 
Second, there is an important over-emphasis on the democratic ideal that institutions and the institutionalization of democratic institutions are intended to foster. While the declared normative interest in democracy is valuable and, I would argue, needed, there are a few problems that are often left unresolved. The first is the undisclosed ideal regarding democracy and its relationship to the historicity of Ecuador's political, economic, cultural and social realities. More specifically, the democratic ideal which authors like Steve Ellner (2012), Conaghan and De la Torre (2008) or Pachano and Garcia (2013) aspire to is largely left undisclosed. What is the type of democracy that should develop in Ecuador? Is that type of democracy fitted particularly for Ecuador? What is the type of democracy that could develop in Ecuador? This analysis regarding democratic institutions, therefore, relies on a basic theoretical-methodological question: Why is there no democracy in Ecuador? This question obscures the analysis of actual state/institutional practices. Put differently, it favours explaining or accounting for the absence of something (strong state institutions) instead of focusing on accounting for the presence of actual institutional/state practices.

Finally, there is the question of power. From this perspective power and legitimacy are intimately linked through the inter-relationship that exists between democratic institutions (mainly electoral ones) and the law. Put differently, the "harmony" of power and legitimacy is seen as necessary for democratic development. The law ought to embody such harmony. State power, therefore, is largely linked to institutional power. Like in classical liberalism (see for instance Locke's “Two Treatises on Civil Government" - 1966; Montesquieu's, "The Spirit of 
the Laws" - 1977; Tocqueville, "Democracy in America - 1966) the power of, for example, the President is understood as the power that the Constitution/law confers on the Presidency of the Republic. In other words, power is seen largely as a juridical form emanating from a central source: the state (cf. Foucault, 1994a). And this is problematic not only theoretically but also historically. In Ecuador in particular, the power of the state through its institutions has been constantly undermined by Constitutional and legal changes. This means that any analysis of power that may be carried out regarding the Ecuadorian case must be conducted beyond the form and importance of juridical forms.

There are also weaknesses in the structuralist approaches that need attention. On the one hand, Ecuadorian neo-Marxists and political economists in particular, elucidate at least two fundamental aspects about the state: first its relationship to class, particularly capitalist classes and second, its role in the reproduction of capital, which requires looking at the state as an international actor. In both instances, neo-Marxists allude to the importance of the relative-autonomy of the state. In other words, the state must be, in the short-term at least, able to go against the interest of capitalist classes in order to guard the interest of capital, or rather, the long-term reproduction of capital (cf. Skocpol, 1985). Notwithstanding important critiques levelled against the level of abstraction of debates about the autonomy of the state (see Conaghan, 1994; Skocpol et al., 1985), there have been important contributions by a series of authors using the concept of autonomy, most notably, Peter Evans and his notion of embedded autonomy (Evans, 1995) and in the Ecuadorian context, writers like Unda (2012). 
Here there are also a series of issues that need attending. Many of the neoMarxist structuralists and political economists, (see Liisa North, 2011-unpublished; Decio Machado, 2012) look at the state in highly instrumental terms: the state responds to structural pressures mainly from foreign capital, but at the same time is used by elites to protect their interests. While elites do utilize state resources, policies and institutions (laws, regulations) to benefit their interests, it is difficult to explain the stability of the state. One could illustrate this point by evoking the spirit of Gramsci's concept of hegemony: the state can be captured by the dominant classes but the capitalist domination of popular sectors by those classes could not be reduced to their will, interests or calculations. Hegemony required, in some senses, the participation of the dominated in their own domination (see Cox, 1983). In other words, the effects of the utilization of the state by the elites (the effects both for the state itself and for society) could not be reduced to the intentions, purposes or will of the elites. State behaviour is largely reduced to class interest. But, as mentioned earlier, the capturing thesis ignores some of the ways power acts upon populations beyond the marginalizing mechanisms that Marxists and political economists identified. While there has been much discussion in the literature about the autonomy of the state and how it may act against capitalists' interests in the short term (see Milliband, 1973, 1979; Poulanzas, 1973, 1976), the dimensions of power linked to the Gramscian concept of hegemony are underplayed. Not unlike Foucault, Gramsci regarded power beyond its utilitarian dimension. The concept of hegemony precisely does that by problematizing the simple notion that state behaviour and class interests are identical (see Cox, 1983). I will address this issue 
in more detail below.

One additional aspect worth mentioning here is the idea that the state is a unitary entity that represents the interests of a class or a site where class struggles take place. It may well be the case that the state represents the interests of capital, but it is another to argue that the state does so coherently, as a unitary actor. In contemporary Ecuador, as I show later, the state and its actions are largely characterized by contradictory actions and some of these actions are often difficult to be made sense of as coherent acts. In addition, structuralists (not all of them Marxists) fail to knowledge the difficulty in accounting for structural changes in the state beyond changes in laws or following exogenous shocks, like wars and financial crises (see for example Tilly, 1985, 1992; Tarrow, 1995). Actions undertaken by the state, at least as far as the historical experience of the Ecuadorian state suggests, cannot always be understood as rational actions. The state and its governmental intervention in society are multiple and are characterized by multiple identities and multiple rationalities. Thus, an interpretive framework for looking/analyzing the state must consider these multiple rationalities and show how they give rise to governmental plans, techniques of intervention and how they come into tension with other forms of interventions by the state.

Finally, in this section I would like to emphasize the theoretical contributions and some areas of concern regarding the literature on populism, both in the context of Ecuador and, more generally, as a theoretical problem. An important positive contribution of the literature on populism, particularly its Weberian or "culturalist" strand, is its focus on a form of authority linked to the charisma of a leader. In 
Ecuador, as mentioned before, multiple analyses have been carried out linking the charisma and leadership style of President Rafael Correa to the way the state is managed and its power structures solidified (e.g. Hurtado, 2006; Muñoz, 2010; De la Torre, 2013). The populism literature bridges the Weberian institutionalist analyses with its culturalist side. This offers a new dimension to the analysis of the state and its reproduction: the linkages between cultural imagery, discourses and narratives that link the population to the state through the presence and actions of a charismatic leader. In Ecuador, for example, as De la Torre has shown, the strength of a leader can be explained by the patriarchal nature of many social relationships in Ecuador and the cultural imaginaries stemming from machismo. In a later chapter I explore, partly aided by this literature, the populist appeal of President Correa's Weekly Presidential Reports and how participatory spaces within the state have been built around the strength of Correa's leadership.

Notwithstanding these contributions, the literature on populism, particularly as it is applied to the Ecuadorian experience and in its Weberian strands (as opposed to, for example, Laclau, 2004) suffers from a few issues worth mentioning here. The first is that populism alone cannot account for the multiple ways in which a state can penetrate society. Modern states, even those deemed populist, like Ecuador's, rely on much more than the charismatic pull of a leader who appeals to the emotions of the populace. States, particularly the Ecuadorian state since 2008, exercise power through various means, some, undoubtedly populist (charismatic authority), but others are rooted in technocratic, knowledge intensive agencies. As I suggest later, the case of SENPLADES clearly illustrates this phenomenon. While the 
populist tradition is aware of the role of knowledge in government, it links it to the overall charismatic-authority argument, as demonstrated earlier. Thus, it underemphasizes the role of knowledge and mentalities in the constitution of governmental regimes and state interventions in society.

I am aware that it is perhaps beyond the scope of some of the literature mentioned here to explain the entirety of the state's power, but it is at the same time difficult to find a discernible limit to the role of a populist form of leadership in their writings: the power of the leader is often stretched to the point where one could plausibly assume that an entire state can be sustained by his/her popular appeal. But this is theoretically, as I have already argued, difficult to show, but it is also historically inaccurate as two of the most charismatic and strongest populist leaders in Ecuador's history, Abdala Bucaram and Jose Maria Velasco Ibarra were overthrown from their posts as Presidents and were clearly unable to develop strong state authorities. Perhaps one of the sources of these shortcomings is that there is too much of a stark separation between Weber's three types of authority: legal-rational, charismatic and traditional. I would argue that this separation needs to be relaxed and allow for interaction between forms of authority to coexist within one project of state development like the Correista one.

\section{Concluding Remarks}

To conclude I would like to address two further issues of importance in the Ecuadorianist literature and in general in literature about the state. The first is that the Ecuadorianist literature is particularly lacking in interpretations that consider 
the state a structure (or post-structure) that needs itself to be problematized. There are exceptions, like, for instance the work of Pablo Ospina $(2009,2010,2013)$. Most of the literature researched for this dissertation about state-formation simply assumes the state. In this sense, even aspects like the rearticulation of the state in a post-neoliberal context is analyzed through the theoretical tools mentioned in this review. Some look at the role of classes in capturing the state (e.g. North, 200), while others at how electoral politics has aided state power (Conaghan and de la Torre, 2008) while others look at how resources like oil prices have helped the development of the state. However, the question of state expansion, the way it penetrates society must be problematized. Good examples of this approach are, just to mention two, James C. Scott's "Seeing like a State"(1998) and Joel Migdal's "State in Society" (2001).

Second, states do no simply penetrate society in unproblematic ways. States repress but also construct consent, empower and enable the strengthening of social forces; states must know and use knowledges in specific ways. Hence state power is a construct that cannot be assumed to be simply "out there" for states (or state elites) to employ at their will. It is, as I argue later, imperative to look at states as a composite of varying relationships, modalities of power, mentalities and techniques of intervention. States are not one monolithic entity composed of many functional parts; states can better be conceptualized as a series of dynamic, governmental regimes whose general aim is to penetrate society and whose ethos is action. Power moreover happens both at the micro as well as macro spaces. Power, as Foucault and the governmentality literature argue, does not emanate from a single source, 
and this insight, akin to Gramsci's notion of hegemony, helps explain why states as well as markets and other structures are, in the grand scheme of things, rather stable and need not recur to coercion to govern over populations.

In the next sections I develop a series of interpretive frameworks that combine, among others, aspects of the Weberian state analysis with governmentality approaches to understanding "the state." I should clarify, before doing so, that it is not my intention to develop an overarching theory of the state or participation, capable of surpassing all the approaches mentioned here. Clearly that would be overly ambitious. Instead I would like to develop a framework for interpreting, historically, the state, particularly state power and a framework that proves useful in answering the research questions that guide this dissertation.

\section{THEORETICAL CONTRIBUTIONS AND CONSIDERATIONS}

\subsection{Studying the Practices and Engagements of the Ecuadorian State}

Max Weber famously defined the state as "a relation of men dominating men, a relation supported by means of legitimate (i.e. considered to be legitimate) violence" (Weber, as cited in Migdal, 2001: 13). Weber's definition highlights that the state is a relation of domination and, therefore, power. There is in Weber's definition an important dimension for the role of police in domination. However, the state does not only dominate through force or the threat to use force, there is ample space for power relations to take place prior to and in between applications of brute force. Thus, one must complement Weber's analysis of the state with one that allows for broader aspects of domination. With this purpose in 
mind, I would like to bring Joel Migdal (cf. 1988; 2001) into the conversation. Migdal's definition of the state transcends Weber's precisely on this point. According to Migdal the state is "(1) The image of a coherent controlling organization in a territory, which is a representation of the people bounded by that territory and (2) the actual practices of its multiple parts" (Migdal, 2009: 16; emphasis on the original).

Both Weber's and Migdal's definitions look at the state as being linked to power practices and material forces. But for Migdal, the state is also an image. This can be thought of as the equivalent applied to states of Benedict Anderson's (1983) definition of a nation as an imagined community: Migdal's definition acknowledges the materiality of practices but adds a narratives aspect to the state in which the state and its power are not only about things, trade, policies, courthouses, money, arms, resources, but also about representations and the construction of imaginaries. This means that to look at the state and state power, one must consider both aspects of the equation: practices and meanings, battles for resources, as well as battles for definitions, for representations (cf. Rojas, 2002).

The state, thus, is at the interstices of practices and images. Hence, I would like to make the following proposition: that the state can be defined as a series of governmental regimes that ultimately rely on the legitimate use of violence to dominate their populations. This working definition synthesizes Weber's and Migdal's through a Foucauldian lens: a governmental regime is a form of power that brings together narratives (images) and practices (techniques, plans, interventions) into an activity called government. As Foucault noted: 
It is the tactics of government which make possible the continual definition and redefinition of what is within the competence of the state and what is not, the public versus the private, and so on; thus the state can only be understood in its survival and its limits on the basis of the general tactics of govermentality (Burchell et al., 1991: 103)

Furthermore, Foucault notes:

The state is not a universal nor in itself an autonomous source of power. The state is nothing else but the effect, the profile, the mobile shape of a perpetual statification (étatisation) or statifications, in the sense of incessant transactions which modify, or move, or drastically change, or insidiously shift sources of finance, modes of investment, decisionmaking centres, forms and types of control, relationships between local powers, the central authority and so on. In short, the state has not heart, as we well know, but not just in the sense that is has no feelings, either good or bad, but it has no heart in the sense that it has no interior. The state is nothing but the mobile effect of a regime of multiple governmentalities (2008: 77; emphasis added).

Consequently, I propose to analyze the Ecuadorian case through a governmentality-inspired approach. Simply put, governmentality can be "understood in the broad sense of techniques and procedures for directing human behaviour. Government of children, government of souls and consciences, government of a household, of a state, or of oneself" (Foucault, 1997: 83). I have decided to call this approach a "post-Foucauldian," "governmentality-inspired" one 
for three reasons: first because many of the fundamental concepts in this dissertation's theoretical approach are not directly Foucault's but derived from the literature on governmentality that has emerged since the 1990s in particular. Perhaps Foucault and a "mainstream" governmentality approach is most useful for analyzing highly organized, "developed" societies of the north in which the conduct of conduct and the self-government are already a reality. Second, as I explain in more detail below, my use of governmentality is not as a theory as such but, following William Walters and Jans Henrik Haahr (2005), as a "form of political analysis"; and third, this theoretical approach, does not completely eschew the contributions of the historical sociology of Weber and incorporates aspects of Weberian and well as other sources, like Migdal and to some extent Gramsci. The approach developed here, in a way, "rehabilitates" an ontologically "stronger" historical-sociological conception of the state than Foucault brought to his analyses of governmentality and the state.

Through a governmentality-inspired approach I intend to analyze and stress three aspects about the state, its reproduction and expansion, that I consider fundamental: first, how it intervenes in society (its intervention schemes); second its power modalities and forms of authority; and third, its constitutive discourses (its regimes of representation). I look at all of these elements as being interrelated and co-constitutive (that is, not one particular element can be analyzed in isolation from the others and all affect their mutual constitution); I also, as I argue below, consider that a governmentality approach is not fundamentally opposed to some of the arguments of structuralists, institutionalists or culturalists. Neither do I 
consider, however, that the approach I propose here is an all-compatible approach. I do argue that a governmentality-inspired approach can be better suited, in many respects, for understanding the transition from a disarticulated state prior to 2006 to a relatively strong state whose presence in society is unprecedented in Ecuador's history. A governmentality approach is, for instance, not inimical to the idea that the state may represent class interests or that institutions, once embedded in social practices may foster democratic development and strengthen the state.

Perhaps the fundamental difference between a governmentality approach and other approaches to studying the state is its level of analysis: it links the mezzo and micro levels without the need to refer to, as Charles Tilly would put it to "big structures, large processes and huge comparisons" (Tilly, 1984). Rather its ontological emphasis is at the level of governmental interventions and the ways in which they become constituted and penetrate society; at the epistemological level its focus is on the interrelationship between knowledge, discourse-practices and power. Both of these "levels" together are, as I hope to show below, able to produce an incisive look at power and the different power modalities exercised by the state over and through its population. A governmentality approach thus, understands governmental regimes actual forms of state behaviour. The state, I propose here, could be understood as a series of governmental regimes that need not be understood as coherent, unitary, rational or progressive (teleological progression of government: governments are continuously improving and learning), but often as contradictory, diverse and even chaotic.

I should also emphasize that one must be wary of not asking a 
governmentality-inspired approach (or any approach for that matter) more than it can offer; this approach has important limitations (some of which I address below) and can be complemented by other theoretical sources. Thus, while this dissertation mainly employs the tools developed by the governmentality school, I also draw from Weberian sources, critical theory (i.e. the Frankfurt School and other Gramscian sources) as well as the state theory of Joel Migdal $(1989,2001)$. This specific combination of sources will allow to expand the governmentality approach proposed here in three specific ways: to understand the relationship between bureaucratic power and state interventions, particularly in the context of forming a technocratic bureaucracy as is the case in Ecuador; to allow for more social agency in the theoretical approach of the dissertation; and third to link governmental interventions to processes of state formation. Hence, in what follows I will attempt to articulate an interpretative framework for understanding the Ecuadorian state since 2008 and its interventions in society, particularly in the area of participation and in its relationship to specific social groups like indigenous organizations.

One of the basic methodological and theoretical premises underlying this dissertation is its historical foundation. I place and understand the Ecuadorian state in a specific historical context: a historical juncture at the interstice between the "end" of neoliberalism and the emergence of a new state form. It was a time (the 2006-2008 period) during which highly politicized social movements sought to reconstitute a disarticulated, elitist state through a new institutional and bureaucratic apparatus as well as a new identity of the state through the enactment of a new Constitution. Since the first time Foucault discussed the concept of 
governmentality in 1978 and 1979, in his lectures at the College de France, he meant it as a historical understanding of a modality of government and political sovereignty (Lemke, 2007; Foucault, 2008, Chapter One). In this sense, I must stress that governmentality entails looking at the government of the state as a process, as a series of effects, beginnings and ends - it means looking at the state as an ongoing project, not a fait accompli.

Furthermore, historically, governmentality is useful given that I am evaluating the "newness" (which is of course not "new" ex nihilo, but "new" understood as a form of rupture and continuity) of a state project and attempting to understand how it was re-articulated after neoliberalism. In this respect, a teleological or path-dependent historical view of the state would provide little analytical purchase. Foucault's preoccupation with the genealogy of government (the genealogy of government rather than that of the state; the state arguably only takes pride of place at a particular moment in this genealogy) points to processes of ruptures instead of continuities to capture meaningful instances of State formation. In Ecuador, it is clear that a moment of rupture occurred in 2006. Like in other countries of the region, such as Venezuela (1998) or Bolivia (2007), Ecuador's population voted in large numbers for a political outsider, an anti-establishment, left-leaning president that both in rhetoric and in concrete plans, represented a break from Ecuador's neoliberal past. One of the most significant instances of political rupture that was brought about by the 2006 presidential election, like in Venezuela and Bolivia, was the drafting of a new Constitution aimed at reconstituting the State. 
Finally, given the research purposes of this dissertation, namely to look at state interventions in society, particularly in the area of participation, I require an analytical approach that sheds light on governmental schemes, plans, techniques and their relationship to larger processes such as a state's political and discursive identity, and its material conditions (funding, economic doctrines). The analytical tools provided by this framework allow for a closer look at the unfolding of governmental regimes: the act of government is never assumed but problematized, investigated and unveiled. Looking at participation, thus, means problematizing the specific ways in which the state constructs the field of participation, its contours, its institutional devices as well as the knowledges and techniques used to do so. The central preoccupation of my research is precisely to understand processes of State formation through an investigation of interventions in society including through participatory planning and as: how was it constructed? What is the role of knowledge in participatory planning? How can power relations be characterized in the micro-spaces of participatory planning? Who are the actors and how are they constituted as such during participatory planning processes?

\subsection{Governmentality and the State?}

This dissertation, as mentioned in Chapter One, is closer to the research "program" initiated by what could be termed the "German", as opposed to the AngloAmerican, governmentality school. ${ }^{9}$ Important authors in this tradition include Bob Jessop $(2007,2008)$, Tomas Lemke $(2007,2010)$ and to some degree, it could be

\footnotetext{
${ }^{9}$ I am indebted to Professor Hans-Martin Jaeger for making this distinction clear to me.
} 
argued, William Walters (see for example, Walters, 2012: 16-19) and Mitchell Dean (2002: 37). At first, governmentality may not appear as an obvious choice to study the state. Not only did Foucault was wary of developing a "theory of the state" (Foucault, 1994a), but an important portion of the governmentality literature has been devoted to studying power beyond the state (see Rose and Miller, 1992). However, Foucault's uneasiness about the development of a general theory of the state can also be interpreted from a different angle. Rather than looking at the state as a whole, or developing, as Theda Skocpol (1985: Chapter 1) suggests, a "statecentric" (as opposed to a society-centered) theory with the state as a central and unified actor, one could instead look at the state as a series of governmental regimes that harness societal processes towards its governmental telos. As Bob Jessop (2007: 37) notes,

In short, to study governmentality in its generic sense is to study the historical constitution of different state forms in and through changing practices of government without assuming that the state has a universal or general essence. This is why Foucault criticized analyses of the state (and/or states) as a juridico-political instance, a calculating subject, an instrument of class rule, or an epiphenomenon of production relations. Nonetheless, whilst eschewing any general theory of the state, he certainly explored emergent strategies (state projects, governmentalizing projects) that identified the nature and purposes of government (as reflected in alternative forms of raison d'e 'tat) in different contexts and periods. 
In this manner the problem of a unified theory of the state can be avoided and the indigestible meal bypassed. Additionally, the state and its actions are understood, through a governmentality approach, beyond their structural limitations. Governmentality is also concerned with the varying narratives and discoursepractices that help constitute the state as governmental regimes. Below I develop the specific tools of a governmentality approach in detail.

\subsection{Studying the State as Governmental Regimes}

As mentioned in the introduction, this dissertation is concerned with the rearticulation of the Ecuadorian state since 2008. To analyze this process I look into various facets of state formation: its constitutive discourses, its bureaucratic apparatus and its interventions in society through participatory planning. I also look at the power modalities exercised by the state in order to intervene in social spaces. To do so, following William Walters and Jens Henrik Haahr (2005: 289-292) I employ the concept of governmentality in two specific ways: First as a form of political analysis; I also look at governmentality as the historical development of a form of power rooted in government - in the conduct of conduct. This approach understands government as "a form of activity aiming to shape, guide or affect the conduct of some person or persons ... government encompasses not only the government of others but the various ways in which we govern ourselves'” (Gordon, as cited in Walters and Haahr, 2005: 290). Two important research questions can be derived from this first theoretical proposition: a) How are we governed; and b) How do we govern ourselves? 
Furthermore, governmentality as political analysis entails analyzing government and its constitutive mentalities, rationalities and practices; in other words, the relationship between government and forms of thought. It "seeks to disclose the forms of political reason which inform, and are often presupposed by particular types of government. It interrogates the way in which different regimes have posed certain problems of rule: who can govern; who is to be governed; what is to be governed, and how?" (Walters and Haahr, 2005: 290). A mentality can be defined as,

a collective, relatively-bounded form of thought in which individuals and groups are typically immersed. As such, a mentality is not always 'readily examined by those who inhabit it' ... As a form of political analysis, governmentality thus aims to be critical and reflexive; for, it seeks to make explicit the forms of political reason and ethical assumptions that are embedded in our activities of government (Walters and Haahr, 2005: 290).

Additionally, as Nikolas Rose and Peter Miller (1992: 176) note, a problematics of government [governmentality] should be analyzed in terms of their governmental technologies, the complex of mundane programmes, calculations, techniques, apparatuses, documents and procedures through which authorities seek to embody and give effect to governmental practices. Through an analysis of the intricate interdependencies between political rationalities and governmental technologies, we can begin to understand the multiple and delicate 
networks that connect the lives of individuals, groups and organizations to the aspirations of authorities in the advanced liberal democracies of the present.

Consequently, governmentality allows me to link issues of participation and planning techniques to a specific understanding, held by the government, of what participation entails and how it ought to be governed. To the contrary, structuralist and institutionalist approaches to state formation, fail to account for the relationship between different rationalities of government and techniques of government. An institutionalist analysis of participatory processes, for instance, would analyze whether popular participation in government is being carried out or not according to its juridical forms. This type of analysis, however, misses to account for the multiple ways in which normative bodies (laws, regulations, formal rules) can be turned into practices. Similarly, such an analysis would miss the diverse ways in which a government rationalizes its interventions in society in order to govern without recurring to force. Thus, in the context of participatory processes organized by SENPLADES, a governmentality approach allows me to make intelligible the process through which something called "participation" becomes a governable space.

After considering what has been said two additional research-guiding questions can be derived: c) what are the mentalities and forms of rationality that the state "employs" in its own definition as a social actor? d) how are these mentalities turned into concrete governmental practices, by what means (agencies, 
institutions, regulations etc.) and techniques (calculations, censuses, statistics, maps, workshops etc.)?

\subsection{The State Apparatus}

Not all states are the same; this was made clear early on by Max Weber (1983). Besides differences in political and economic regimes, states are different in their internal organization. The importance of a bureaucratic structure for states is well recognized. In a well-known exploration of bureaucratic politics Graham Allison (1971) shows the direct linkages between a bureaucratic post and the behaviour of state actors - where you sit determines the way you act. Similarly, Weberian-influenced scholars have emphasized the importance of a modern, efficient and effective bureaucratic apparatus for developmental states. Peter Evans (1995), for example, in his well-known study of varying state forms (predatory, developmental and hybrid) shows that state behaviour is partly dependent upon its internal organization and the "Weberian hypothesis must be explored across [state] agencies and countries" (Evans, 1995: 40). Moreover, Evans continues, "[l]ooking at the state agencies involved in particular industrial sectors ... is one way of putting more empirical meat on the idea that it is scarcity rather than surfeit of bureaucracy that impedes development" (Ibid.).

Looking at the comportment of state agencies and the bureaucratic apparatus is one of the ways in which Evans differentiates the effect on industry of different states. Evans was interested in the role of the state in industrial transformation, nonetheless, one can extrapolate Evans's argument to participation: 
Looking at state agencies in charge of fostering participation is essential to understand the type of state and the type of participation being promoted. At the same time, however, I consider it fundamental to problematize the idea that more, not less bureaucracy is better for development. Particularly in the area of participation the Weberian hypothesis, as I argue in a later chapter, may not apply.

At the same time, as Lemke (2007: 2) points out, "government by state agencies must be conceived of as a contingent political process and a singular historical event in need of explanation rather than a given fact." Governmentality studies are interested precisely in providing such an analysis. According to Bob Jessop, to study governmentality is to study the "historical constitution of different state forms in and through changing practices of government without assuming that the state has a universal or general essence." Nonetheless, Jessop continues, "whilst eschewing any general theory of the state, [Foucault] certainly explored emergent strategies (state projects, governmentalizing projects) that identified the nature and purposes of government (as reflected in alternative forms of raison d'état) in different contexts and periods" (Jessop, 2007: 37).

In summary, following Weber and Foucault, Evans and Lemke, it is important in studying a state, to link types of state interventions to the type of agencies that carry them out, and more, generally, to the bureaucratic apparatus of a state. By looking at the type of bureaucracy of a state one can, thus, derive conclusions about its identity (e.g. developmentalist, predatory, intermediate) and its mechanisms for penetrating society or as Evans would put it, its forms of social embeddedness. 
Thus far it has been argued that the state can be understood as a series of governmental regimes. These regimes are characterized by different mentalities and techniques which are carried out by different types of state agencies, ministries, organizations, etc. One highly important issue that has not thus far been discussed is the question of power. After all, it is fundamental for understanding the interventions of a state in society, the degree to which government can rule, to what extent and through which mechanism. In order to understand this issue one must inescapably speak about state power. What types/modalities of power are exercised through and in the name of the state? I tackle this question in turn.

\subsection{The State and Modalities Power}

As argued earlier the state is practices as well as images, mentalities and techniques. Thus, an analysis of the state as a series of governmental regimes would require recognizing that power goes beyond its juridical and police forms. This proposition has, at least, two implications: First, power and rule cannot be reduced to juridical and/or police forms; and second, power is more than prohibition, coercion and punishment. This notion of power beyond negation is recognized by a number of intellectual traditions like Gramscianism whose concept of hegemony gives a more prevalent role to classical Marxism's superstructure. Weberians, too, recognize that power is more than domination through the legitimate claim to the use of violence. Weber's charismatic authority, for example, can be defined as a form of power that employs persuasion rather than coercion. In like-fashion governmentality studies follow Foucault's lead in identifying various modalities of 
power within his broader definition of power as an action that delimits or constrains the realm of possibility of another action (Foucault, 1994a), The different historical configurations of power identified by Foucault were: sovereign, disciplinary and government.

In brief, sovereign power means domination through, in a way, the management of death. Foucault thought of sovereign power as the monarch's absolute power to administer death. Power was the monarch and he had the power to kill and let live. By contrast biopower is the power to potentialize life, manage health, wellbeing. In a way then biopower is power over (or through) life, rather than death (see Foucault, 2000: March 17, 1976 Lecture). Disciplinary power is a way to manage populations through regimes of discipline (as in schools, barracks, asylums). In contrast to sovereign power the definition of discipline entails the transformation of subjectivities. By definition, it entails a process of improvementnormalization through regimes of discipline (disciplinary power is further discussed below). Finally, governmental power stems from Foucault's effort at responding to Marxist critiques regarding his conception of power's inability to deal with larger power configurations, more specifically to account for his failure "to offer a proper consideration of the nature of and organization of the state" (Walters, 2012: 15). Both biopower and governmental power are forms of understanding modern regimes of rule, many of which are rooted in the administration of life, not death; freedom, not restriction and self-government not police-juridical enforcement (Dean, 1999; Walters, 2012).

Before discussing some of the constitutive elements of what Foucault thought 
of as "power" in a more general sense, I would like to discuss, mainly the idea of disciplinary power employed by this work. First, I should note that the use of discipline in this work is derived in important aspects from the Foucauldian notion of discipline but departs from Foucault to address forms of discipline that are not necessarily linked to its direct application on human bodies in institutionalized settings. I seek to expand the concept of discipline to settings beyond the school, the prison or the factory and into actions that seek to transform subjects through correctional acts that may include coercive forms like jailing and or techniques of intimidation. In this sense, many of the uses of the notion of discipline in this works, particularly in Chapter Seven, are inspired by Foucault but are not in a strict sense "Foucauldian" (cf. Foucault, 2000: 43).

Discipline's main focus is the normalization of populations through more or less extended periods of disciplinary regimes; it is a type of power concerned with the creation of a "generalized regulatory mechanism for the production of docile and useful subjects" (Dean, 1999: 122). Disciplinary power is

Continuously exercised through surveillance and not in a discontinuous manner through systems of chronic canons and obligations. It is a type of power that presupposes a tight grid of material coercions more so than the physical existence of a sovereign and that defines a new economy of power whose overarching principle is to increase, at once, the those forces which are subdued and the forces and efficacy of who subdues them ... (Foucault, 2000: 43; my translation).

Discipline targets "bodily capacities, forces, habits and dispositions" 
(Walters, 2012: 34) and in this sense, it could argued, is intimately linked to the production of autonomous, self-regulating individuals capable of being, eventually, governed from afar. It is important to clarify that the notion of government from afar belongs to the realm of power Foucault called government. However, since the ultimate objective of discipline is to generate docile and/or useful subjects, a corollary of discipline is to produce subjects that need not be perpetually subjected to disciplinary regimes. In this sense discipline and government are intimately linked. A good example of a disciplinary institution is the military. In a military barracks, men and women are subjected to a series of techniques (marching, tightscheduling, etc.) designed to transform a woman or man into a soldier - a transformation in subjectivity. Discipline implies the temporary limiting of the individual's or group's freedom until the process of normalization is complete. Thus, an important difference between disciplinary and sovereign power is that in sovereign power regimes the tortured or imprisoned, are not thought of as "corrigible." ("corrigible" means being apt to becoming "normal"). Their aim of power is not to transform the subject but to use her as an example (see Foucault, 1977: Chapter One).

In this work I draw a further link between discipline and government: another objective of discipline is the inclusion of "docile and useful" subjects into governmental regimes of "improvement" (cf. Li, 2007a). For example, a strong discourse like Arturo Escobar's historical concept of "development" (Escobar, 1995) can be thought of as a regime of improvement that also functions as a normalizing mechanism that divides peoples along two broad categories the developed 
("normal") and the underdeveloped ("abnormal"). The conception of discipline employed here looks at the different mechanisms, technologies, and techniques used to incorporate subject into a regime like "development." This may entail, for instance, techniques of shaming designed to prompt a transformation in the behaviour of individuals to appear more "developed." In this understanding of discipline the state may be thought, metaphorically, as a type of panopticon in which subjects are observed and corrected according to the needs of a regime of improvement.

Moreover, I would argue that a fundamental dimension of this understanding of discipline if applied to states is that for an authoritarian state, oppressed populations are deemed incorrigible, so to speak. The intent of power may be to keep a system going and not to transform certain populations. Examples abound, but the most extremes cases are Nazi Germany or Apartheid South Africa. In both of these states oppressed populations were managed through near complete annihilation or radical exclusion, respectively. Neither the Jewish population in Germany nor the Black population in South Africa was deemed to be "corrigible,"10 so to speak. The same can be said of other periods and authoritarian regimes: communist in Pinochet's Chile, blacks in American slavery and segregation. By contrast, in a disciplinary state, subjugated populations are managed through disciplinary actions designed to transform them, or as Foucault would put it,

\footnotetext{
${ }^{10}$ By corrigible I mean populations deemed amenable to the progressive incorporation into a regime of improvement. Put differently, I argue that corrigibility entails that populations are considered capable, if educated, trained, indoctrinated, etc. to be autonomous and capable of self-government within a specific discursive field of government. In this sense, corrigible (like "normal") ought not to be equated with a value judgment or a moral statement about specific regimes, ways if being etc.
} 
normalize them. I think that this is a useful conceptual distinction, as I argue in Chapter Seven, when it comes to evaluating the power modalities exercised by the Ecuadorian state. In its relationship with indigenous populations, for instance, is the Ecuadorian state mainly characterized as disciplinary or authoritarian? I argue in favour of the former.

I should also point out that disciplinary measures could take many different organizational shapes: school, a workfare program, an asylum, a prison or a military regiment (Walters, 2012). Disciplinary actions however need not be organizational but can be psychological, pedagogical, and even symbolic. Examples of this can be shaming campaigns with a variety of purposes, from losing weight to making workers more productive. The central aspect of discipline adopted by this work is to manage particular populations through certain regimes in accordance with the needs of power, that is to say, normalization means being transformed in accordance with the dictums of a particular standard that is formed and associated to a hegemonic order. In this sense, one of the aims of disciplining populations is to reproduce specific power regimes. So, for example, the dominance of Eurocentricwhite culture in countries like Ecuador means that a disciplinary regime will seek to reproduce that culture by cultivating (this could be done by forceful or "softer," more psychological means) in oppressed populations the need to becoming, for example, "whiter," more "European-like" (cf. Hindess, 1997, 2001; cf. Kingman, 2002).

Finally, there is the question of government as a form of power. Much of governmentality as far as power is concerned is about liberal technologies of power, 
mainly, power through freedoms, through self-regulation. But it is important to stress two fundamental aspects about this issue that directly relate to this work: first that governmental power is an historical process, not a static state of affairs. This means that any analysis rooted in governmentality must acknowledge that stages of self-regulation are first continuously being reproduced by agents other than individuals self-regulating, like states and governments. Also, states of liberal, or perhaps more appropriately, neoliberal, self-regulation did not appear overnight; they were encouraged and produced by the acts of governments as well as other forces, like the market. Thus, to say that governmentality is about regulating through freedoms does not entail ignoring the role that governments play in the historical development (and eventually reproduction of self-regulation as a historical fact.

Second, as Walters (2012: 6-7) notes:

A great deal of commentary has conflated governmentality and liberalism ... a careful reading of Foucault's lectures on governmentality reveals that ... in no way does it [liberalism] exhaust the field of governmentality. Drawing attention to other governmentalities, only some of which Foucault has sketched will allow us to see our political present as more heterogeneous than it might otherwise appear.

In similar fashion my research on the state in Ecuador suggests that one of the reasons the state has been so effective in its rearticulation, expansion and reproduction has been because of its exercise of different modalities of power, from governmental to disciplinary. Different modalities of power, as the Ecuadorian case 
suggests, coexist within the same socio-political point in history. Before moving forward it would be worth asking, how does governmentality and power translate into state practices? How is governmentality exercised? I tackle these questions later in this chapter; before doing so the next section develops the notion of neoliberal governmentality.

\subsection{Knowledge, Power and Government}

As a first step to answering these questions I should expand on the notion of positive power. For Foucault power had a strong positive (productive rather than repressive) dimension. In fact, as Mark Haugaard notes, for Foucault the presence of violence signaled the absence of power (Haugaard, 1997: 68). Also of importance is to note that by "positive" Foucault, or governmentality theorists for that matter, did not mean desirable, welcoming - there were no intended normative implications to the notion of "positive" power (see Haugaard, 2012). By positive Foucault meant variously productive, empowering, constructive. This dimension of power is of crucial importance in this dissertation for three reasons: first because it is clear, both from a theoretical as well as an empirical and historical point of view that states do not operate exclusively through force. Second, because modern techniques of power not rooted in oppression or negation or the idea of "power over," must be regarded from a separate theoretical lens; third, when studying the contemporary Ecuadorian state it is evident that much of its processes of rearticulation, including of course its interventions in society, are highly knowledge-based and highly technocratic. 
One of the fundamental theoretical contributions of the governmentality literature is precisely to link power to knowledge and discourse practices. This is an opportune moment to recall Migdal's idea that the state is both image and practice. Because the state is both image and practice it is fundamental to inquire into the power mechanisms that operate in creating the image of the state. There are, of course, questions of territory, nationhood and so on. But also, and very importantly, there is the image of the "government as the essence of efficacy" (Barthes, as cited in Lemke, 2007: 2). In fact, this notion is precisely the first use given to the term "governmentality" by French Theorist Roland Barthes in his 1957 book Mythologies (Barthes, 1957; Lemke, 2007). The essence of efficacy is not only in reference to "getting things done" but getting them done in the right fashion. But, what is "right"? And how does government construct such an image? It was precisely in the relationship between power and "right," or more specifically, power and truth, that Foucault was interested (see for example, Foucault 1994a: 111-133). Without entering into an extensive philosophical and/or metaphysical discussion about the relationship between truth and power, there are a few issues that need consideration.

One of the fundamental and long-lasting contributions by Foucault to the study of power was to make intelligible the close and intricate linkages and relationships that exist between power and knowledge. For Foucault unveiling the positive dimension of power meant digging into the relationship between power and knowledge. In short, Foucault thought that power and knowledge are not separable: Foucault took the truism "knowledge is power" a step further by 
asserting not only that knowledge is power, but that power is knowledge as well. In short, for every field of knowledge to emerge there must be a corresponding field of power enabling it; similarly, for every form of power to exist, there must be a field of knowledge validating its purpose, its raison d'etre. This equation is particularly relevant and applicable to the notion of productive power. Productive power, unlike destructive, coercive power, must rely on knowledge in order to be productive. To provide a simple example: women's empowerment about their sexuality, can hardly be separated from knowledge about, among other things, reproductive health and reproductive rights.

From the perspective of governmentality and studying the state, as HansMartin Jaeger (2010: 52) notes, governmentality implies fundamentally "historically variable ways of imagining and directing conduct with the help of specific, often technical, knowledges (or rationalities) and methods." One of the central tenets of governmentality, as indicated before, is that "government defines a discursive field in which exercising power is 'rationalized.' (Lemke, 2007: 2; emphasis added). And for this the government needs specific fields of knowledge that invest its interventions with a mantle of "technical expertise." Hence, to study governmental interventions in society means looking at how the state through its different agencies constructs: a) an image if itself as the essence of efficacy as well as the essence of right; b) the fields of knowledge and techniques that it employs to construct such an image and c) the narratives and discourses employed in defining governmental spaces and state legitimacy. Hence, and in synthesis, the following proposition can be made: the power of the state, particularly in modern democratic 
states is partly rooted in the knowledge production and the knowledge fields it can generate; the narratives and discourses through which the state seeks to instil in the population an image of itself that is, if not legitimating, at least an image that justifies state interventions in society. Empirically this means studying the state from the perspective of the agencies that are in charge of producing and disseminating knowledge. As I show later, I demonstrate this theoretical proposition through the study of SENPLADES and the construction of the PNBV.

It becomes evident, from what was just discussed, that as the state tries to penetrate society through an image of efficacy and right, it will often encounter opposition from those who do not accept such images. As Migdal notes: While the image of the state implies a singular morality, one standard way, indeed one right way, of doing things, practices denote multiple types of performance and, possibly, some contention over what is the right way to act (Migdal, 2009: 19). I will address the issue of opposition/ resistance to power in a later section. Here I will address some of the specific ways through which, besides violence, repression, and/or coercion, the state seeks to control populations - that is, to make effective the image of efficacy and right). Following the governmentality literature, particularly Mitchell Dean $(1999,2010)$, as well as other theoretical resources, particularly Mary Louise Pratt's concept of autoethnography, I will discuss specific mechanisms through which the government exercises its rule over and through society.

Before doing so I should reiterate a central theoretical and methodological aspect of this dissertation. As mentioned in the Introduction, my research, hypotheses and arguments are about the state, not about social groups. This does 
not mean that one can easily separate the two. As discussed, these are inseparable entities. Nonetheless, I focus, without making judgments about society's compliance to state power, on the different strategies, mechanisms, and contexts in which the state seeks domination and control. In other words, my interest is in problematizing state interventions, not so much responses to those interventions. I make this distinction to make this project feasible and to elucidate what happens "within" the state: this is one of the central ontological assumptions made by this dissertation.

Mary Pratt developed the concept of autoethnography to refer to instances in which,

Colonized subjects undertake to represent themselves in ways that engage with the colonizer's own terms ... If ethnographic texts are a means by which Europeans represent to themselves their (usually subjugated) others, autoethnographic texts are those the others construct in response to or in dialogue with those metropolitan representations ... Autoethnographic texts are not, then, what are usually thought of as "authentic"; or autochthonous forms of self-representation ... Rather autoethnography involves partial collaboration with and appropriation of the idioms of the conqueror ... Autoethnographic texts are typically heterogeneous on the reception end as well, usually addressed both to metropolitan readers and to literate sectors of the speaker's own social group, and bound to be received very differently by each (Pratt, 1992: 7).

Admittedly Pratt is coming from the perspective of colonial relations as well as from 
an anthropological point of view. Nonetheless, her concept above all aims at representing political relations between the colonial state and its subject. In this sense, her understanding of autoethnograhic representations, while most relevant for colonial relations helps to understand the various ways in which the state and its subjects seek to self-represent in the eyes of the other.

Even though Pratt is primarily concerned with colonial subjects (indigenous peoples from the Andes), her definition of autoethnography can be applied to state power as something I would call "reverse-autoethnography." By reverseautoethnography I mean the ways in which the state (or a dominant actor for that matter) through its various programs, agencies, documents, Ministries and, more generally, its interventions in society represents itself through the language and perspective of marginalized subjects, particularly indigenous peoples to represent itself in terms of the subject's own terms.

During the research process for this dissertation it became evident that concepts like "subjugated knowledges" and/or "marginalized epistemologies," which are popular in the Foucauldian-oriented literature (see for instance, Escobar, 2010; Bahba, 2003; Foucault, 2003), were not enough to capture the fact that the post-2008 state (that is, the post-Constituent Assembly state) had begun to selfrepresent through the language of indigenous populations, through the "philosophy" of Sumak Kawsay (SK). I will discuss this issue in detail later, but I should not here that one of the most compelling and significant aspects of SK are its radical contents, some of which challenge the very existence of the state (see for example Walsh, $2009,2010)$. In this sense, an important question emerges: what is the relationship 
between government and the language of SK? I argue, that through the use of reverse-autoethnography SK has been, if not completely stripped, at least substantially voided of its radical content. From a theoretical stance I contend that reverse-autoethnography is a governmental technique, rooted in non-coercive power, aimed at countering radical narratives and movements emerging from nonstate actors, like Ecuador's indigenous movement and radical NGOs.

\subsection{Regimes, Practices and Technologies of Government}

In addition to reverse-autoethnography governments use several other practical techniques rooted in the same equation: knowledge-power-knowledgepower. These techniques are a prior step to the creation of public policy and programs. Some of these techniques include: the constitution of populations, acts of problematization, the production of technical solutions through technical knowledges, charts, statistics, maps, and other devices that help constitute a field for intervention (participation, health, the economy, education, tourism, etc.). The constitution of a field of intervention of a governmental regime follows one of Foucault's basic methodological propositions: genealogy. A central tenet of this "method" is that fields like health, the economy and/or participation, cannot be assumed to exist a priori. In the words of Jacques Donzelot:

[Foucault] did not set out to show the historical relativity of these objects, or even to deny their validity, as has often been said, but postulated a priori their non-existence, thus dismantling all our certainties concerning them, including that of their pure historicity. This 
enabled him to reveal how something which did not exist could come about, how a set of practices were able to come together to produce a regime of truth with regard to these objects, a combination of power and knowledge which makes it possible to say, at least insofar as the regime of truth succeeded in being effective what was true and false in matters concerning madness, delinquency, sexuality and government (Donzelot, as cited in Walters, 2012: 17; emphasis in original).

Drawing from this perspective it can be said that governmental regimes' interventions in society depend upon and are designed by at least three concrete practices: First the constitution of populations; second acts of problematization; third, the creation of technical knowledges and techniques of intervention.

\section{The Constitution of Populations}

Populations offer the type of regularities that enable governments to employ calculated means to intervene in society: calculating the rates of births and deaths, aging, health, number of men and women of working age etc. The sovereign modality of rule of the monarchies of Europe prior to the 17th century was rooted in the model of the family (Dean, 1999, Foucault, 1994a). But in modern forms of rule "populations provide the key to overcoming the model of the family, which was too narrow, weak and insubstantial; and a framework based on sovereignty that was excessively large, abstract and rigid (Foucault, 2007: 103). It is the notion of populations that makes possible the elaboration of distinctively governmental techniques and rationalities ..." (Dean, 1999: 127). In addition, populations, while 
possessing their own interests, history and characteristics are unlike other governable groups like unions, ethnic organizations, religious groups and so on, highly amenable to being ruled by government and large management processes. Populations are at once portrayed as homogenous, large conglomerations of individuals united by government, as well a series of dispersed individuals, unable to become organized under the concept of "population." Thus, the creation of a "population" constitutes the fundamental ontology of modern governmental rule. This is the first step in the constitution of a regime of governmental interventions. It should be noted that I am not saying here that populations are indeed homogenous, but their (often statistical) representations are. The regularities in the representation through statistical knowledges turn populations into a more manageable processes.

But, it should be noted, populations, contrary to what common intuition may suggest, are not simply "out there." Populations are constituted through knowledge practices through calculable patterns like poverty, inequality, education levels, age groups, race and so on. This is one of the reasons censuses are so prevalent and at the same time so important for making governmental rationalities intelligible. Kim Clark (1998: 185), for instance, notes that, "while statistics seem to present objective data through the simple counting of already existing facts, the very categories used in their collection reveal conceptions of society and personhood." The relationship between population and government is captured elegantly by this quote from an Ecuadorian governmental official working in the 1950s: "the census is a statistic that is of interest to everyone: the merchant for his business, the 
agriculturalist for his crops, the industrialist for his production, the worker for his culturalization [culturalización] and the peasant for his improvement [mejoramiento]' (Clark, 1998: 198). Moreover, Clark shows the mentality about the census at the time was to establish "how many useful people there are in the republic. ... How many citizens the republic has and how many passive people there are, to whom it is of no interest or importance what happens, because their capacity for culture is completely deficient" (Ibid.). In synthesis, what Clark shows with the example of Ecuador's first census is precisely what Foucault would have predicted: that one of the objectives of modern rule is to produce useful subjects, but also, that this logic of rule is rooted in a discursive field that regarded indigenous populations as backward and as in need of being cultured. Some of these themes will appear again in the course of this dissertation, particularly in Chapters 5 and 6.

\section{Problematization}

In short a 'problematization' means "calling into question how we shape and direct our own and others' conduct" (Dean, 1999: 38). The point behind this concept is not whether or not governments problematize (although sometimes they clearly do not) but how they do so and what elements, groups, issues, and considerations are left in/out of the field being problematized. As mentioned by Dean, problematizing an issue is not just about posing technical questions about an issue, like participation. Rather it is to call into question how to govern participation. Hence, it could be said that problematization is a two-fold process: on the one hand is the act of creating, or at least clarifying the contours of an issue-area appropriate for governmental intervention and second, it asks how to best govern it. In the area 
of participation, for instance, the issue of problematization is quite clear. First, prior to the Constituent Assembly of 2007-2008, participation in Ecuador was not a field that was constituted by the state but was an expression associated with social movements, unions, the indigenous movement etc. However, after clear demands from social movements about the need to increase popular participation in policymaking, the state was confronted with the need to both create a field called "participation" and identify how to best govern it. Neither of these acts is, of course, self-evident or obvious. As I show in Chapters 5 and 6, participation was moulded in very specific ways, from the institutional-normative sphere to the level of practice. This "specificity" means that many other ways of conceiving participation were left out of the field of government now called participation.

Thus, in order to study regimes of government it is necessary to inquire into how governments problematize issues. Moreover, one must ask, what are the implications of such processes, particularly, as what issues have been left out. The overall point, following Foucault's genealogical method, is to make evident the fact that participation is a governmental creation, not an a priori category. As I said earlier, governments attempt to create an image of "the essence of efficacy" and the essence of right and in doing so seek to portray a particular field of intervention as an unquestionable reality. Thus, studying governmental regimes means showing the "constructed" nature of fields of governmental intervention.

\section{Technical Knowledges and Techniques of Intervention}

In theory, problematizations "are made on the basis of particular techniques, 
language, grids of analysis and evaluation, forms of knowledge and expertise" (Dean, 1999: 38). The relationship between knowledge and government is, as I have already discussed, fundamental; however, in more specific terms, technical knowledges directly relate to how governments in modern states delineate or frame areas of intervention and create specific solutions to problems. Rather than the specific content of a technical knowledge, this category refers to the manner in which knowledge is utilized to render issues technical. The actual content of the knowledge may be mundane and even simplistic, as long as it "extracts from the messiness of the social world, with all the processes that run though it, a set of relations that can be formulated as a diagram in which problem (a) plus intervention (b) will produce (c), a beneficial result" (Li, 2007b: 264). Along with the act of problematization, technical knowledges disclose a certain range of possible solutions for problems and allow certain individuals to become authorities in the offering of solutions. These individuals are called "experts"; and the rule by experts is called a technocracy. As I show later, one of the fundamental characteristics of the Ecuadorian state, starting from its PhD-trained President is its reliance on technical knowledges and experts; I illustrate this theoretical scenario, empirically, through the case of the PBNV.

In this sense a governmentality analysis of the state reveals important aspects of the political dimension of government. For instance, it reveals, as I show in more detail in Chapter Six, the role of experts and expert knowledges in dealing with questions that belong to their general domain of expertise but that go beyond the technical language and knowledge that they possess and utilize. To paraphrase 
Nikolas Rose the point is to find out "switch points," that is, where critical scrutiny of governmental programs is absorbed back into the realm of expertise, and "an opening turns into a closure." (Rose, as cited in Li, 2007: 11), for instance, where autoethnography turns into reverse-autoethnography. There are a number of issues to look for in this respect. First, "switch points," which can also be phrased in decolonial terms as a colonial silencing through knowledge practices; second, the reverse: "the conditions under which expert discourse is punctured by a challenge it cannot contain; moments when the targets of expert schemes reveal, in word or deed, their own critical analysis of the problems that confront them" (Li, 2007: 11); and third, the ways in which targets of expert knowledge succeed in incorporating their own knowledge into a governmental scheme (through participatory planning, for example).

At the same time, however, one may pose the question: is it not an obvious fact that modern governments must rely on knowledge in order to govern? The answer is, clearly, "yes." However, the question that interests me here, and that is relevant for studying governmental regimes, is not whether governments use knowledge, but what kind of knowledge, what issues are revealed by its use and what issues are left unattended? The objective of this methodological choice is to problematize issues and solutions that may appear obvious, evident and/or automatic. Outlining these issues is an important element in understanding political conflict and state formation. Specifically a few theoretical scenarios are possible: first, social forces may demand solutions that go beyond the technical means of the state, social conflict may ensue; second, if government through technical 
knowledges is effective, it means depoliticizing issues and social forces rendering social protest ineffective and social change less likely.

\section{(Neo)Liberal Techniques of Rule}

One of the important contributions of the governmentality school is to analyze liberal techniques of rule. While the analysis of liberalism is extensive in the governmentality literature, this section focuses on liberal techniques and technologies of rule. Like problematization, or rendering technical, liberal techniques of rule are important technologies of government but, unlike the former, liberal technologies of rule rely on non-state social actors to act in the construction of their own government. Mitchell Dean (2002: 38; emphasis in original) encapsulates the core of liberal governmentality as follows: "governing liberally does not necessarily entail governing through freedom or even governing in a manner that respects individual liberty. It might mean ... overriding the exercise of specific freedoms in order to enforce obligations on members of the population." This means that,

The activity of the government of the state is not an end in itself, as it is in doctrines of 'reason of state', but something done on behalf of what lies outside the state. It is society, not the state, that helps determine 'why there has to be government, to what extent it can be done without, and in which cases it is needless or harmful for it to intervene'

This theoretical view appears particularly relevant to interpret some aspects of state action in the current democratic epoch in Ecuador (and in Latin America). 
It is crucial to situate theory in historical terms and, consequently, it is imperative to remember that since the 1980s South America as a region has largely entered into a period in which procedural democracy, particularly electoral democracy has been the norm. It is in this historical context that the slogan behind the Correista state, the "Citizens' Revolution" was born. This entails that certain dimensions of rule rely in society, not the state, even if in the end, the state is strengthened. Some of these techniques include referenda, plebiscites and, more generally, the constant call to electoral contests.

\subsection{Governmentality's Historical Stance}

The historicity of governmentality is concerned with the constitution of what Foucault calls epistemes or what Cristina Rojas calls regimes of representation (2002). This entails that identities must be seen in relation to fields of knowledge (Foucault, 1980, 1994a; Dean, 1999; Escobar, 1995, 2010). Foucault's notion that there is a social will to knowledge; that knowledge, power and discourse are intimately linked is crucial (Foucault, 1972, 1980, 1994a), for it allows a view of history based on a genealogy of regimes of representation. In contrast to other approaches to history common in the social sciences, such as path dependence, or Hegelian teleology, my understanding of history contends that there are no historical accumulations, linear progress or a transcendental logic to historical development. History must be investigated in small fragments; in its moments of ruptures; and by observing the marginal voices of history. Power is better understood from the margins (Mohanty, 2008; Heckman, 1996). Thus, to 
understand the historical policy of state formation through participatory engagements and participatory planning one must not only look at what the State did and continues to do, but also at dissenting voices, at the ruptures in regimes of representation and to the voice of the margins, like indigenous peoples, and their relationship to those regimes of representation.

For Foucault the genealogical method was an essential tool that defined his studies of government, power, subjectivity and the state. As I said, governmentality can be understood as a guideline for the genealogical study of the modern state. In this sense, governmentality, it should be made clear, is a continuation of Foucauldian analytics concerned with power, knowledge, regimes of representation and modes of intervention (Lemke, 2007: 2). Governmentality, thus, allows me to look at the state as a historical construction through discontinuities in the past and the present. Genealogically, I can situate the condition of the Ecuadorian State as a fragmentary expression of a particular historical moment. In my research of SENPLADES and its planning systems and participatory engagements with indigenous organizations, I can situate planning and participation as a particular set of rationalities and techniques of government that makes a particular form of governing possible. While governmentality has allowed many researchers to conceptualize the neoliberalism as government through freedoms (e.g. Drinot, 2011; Hindness, 2001; Lemke, 2000) governmentality gives me the theoretical tools that enable me to link processes of state formation to planning and participatory processes beyond neoliberalism, and therefore, to interpret the development of the "new-left" in Ecuador (and potentially in other parts of Latin America) beyond 
traditional binarisms such as left vs. right; populism vs. democracy; advanced vs. stagnant; authoritarian vs. liberal.

To conclude this section, I should summarize some of the most important aspects I have addressed so far. The first is the importance of looking at the state from the point of view of its mentalities, techniques and rationalities. Second, I have emphasized the Foucauldian notion of power operating on and through individuals with or without their consent or them being aware of it; third, I have brought attention to the very important theoretical issue of depoliticization and its relationship to knowledge. Finally I have emphasized the question of history, the state and genealogy to show the relationship between governmentality and forms of rule from a historical perspective.

In synthesis, the first portion of this chapter has outlined ways of understanding the state as a series of governmental interventions as well as specifying the actual components of a governmental regime. The conjunction of elements such as state narratives, including reverse-autoethnography, acts of problematization, rendering issues technical and so on is what I call a governmental regime. In short, governmental regimes seek to govern by "educating desires and configuring habits, aspirations and beliefs" (Li, 2007a: 5). But configuring a series of governmental regimes is only part of the equation. As governmental regimes seek to penetrate society they will encounter opposition. As Foucault (1994a: 327-348) noted, where there is power, there is resistance to power. I will tackle the relationship of resistance to power in a later section; before doing so, however, I would like to address in more detail the issue of politics. Resistance is a political act 
and the lack of politics means lack of resistance. Thus, stripping issues of their political content may be an effective, albeit temporal, form of rule. In the following section I address the issue of politics and (de)politicization.

\subsection{Politics and De-Politicization}

An important application of Foucauldian and governmentality analytics has been carried out in the field of political analysis, particularly in how governmental techniques can be "anti-political" (e.g. cf. Owen, 1995; Ferguson, 1994a; Li 2007a, 2007;). The issue of politicization is of importance for my work, particularly because a central piece of my argumentation is the relationship between regimes of government and politics. In this section, drawing from diverse but compatible theoretical sources, I attempt to provide a working (useful) definition of "the political." Before doing so, I should note that I acknowledge that, as James C. Scott $(1985,1998)$ has shown, politics can occur in small spaces, within resourceless regions, at the level of communities as well as individuals. Indeed, in some sense politics could be said to be everywhere. However and notwithstanding the validity (and problems) of these assertions, due to the notoriously copious array of existing and past discussions about politics, I will for the sake of theoretical neatness concentrate on politics at the level of organized groups within civil society and politics in the context of state-society relations - which may entail looking, as I do in Chapter Seven at micro spaces of political encounters such as the PNBV workshops.

A good place to start this discussion is Chantale Mouffe's (2000) and Marisol de La Cadena's definition of politics as 
the field that makes antagonism liveable, curbs or even cancels its warlike potential, without ever cancelling the conflict it entails. Politics are ... those practices through which the antagonistic differences between friends and enemies are tamed, dealt with (ideologically and institutionally) and transformed into the agonisms-the relationships among adversaries-that characterize hegemonic orders, with their inclusions and exclusions (Mouffe, as cited in de la Cadena, 2010: 343).

Conflict, strategies, and power are, thus, important elements of politics; however, it is worth noting that political agonisms need to be between adversaries, politics and difference can emerge within groups of the same denomination. I would argue, however, that above all, this perspective stresses politics as the means of existence of opposites; it entails that "the political" can be thought of as the field of discourse-practice where opposites are allowed to emerge.

Another important source of theoretical thinking about politics comes from Jacques Rancière (1995, 2001, 2006; Chambers, 2011). Here I will only address Rancière's basic tenets regarding politics. In his well-known article Ten Theses on Politics (2001) Rancière outlines some of his most important arguments regarding the fundamentals of politics, particularly the opposition between politics and police. For Rancière politics is "a mode of acting put into practice by a specific kind of subject and deriving from a particular form of reason. It is the political relationship that allows one to think the possibility of a political subject(ivity) [le sujet politique] not the other way around" (Rancière, 2001: 3); moreover, this subject(ivity) is defined through its participation in contrarieties and dissensus. Here Rancière 
determined a necessary condition for the emergence of politics: engagement and participation, and, particularly, dissensus, subjectivation and subjectification. As Rancière notes, there is no political subject prior to its participation in contrarieties, disagreement and dissensus and in a specified form of reason and discourse. Unlike say, Marx's worker whose political inclinations are assumed to exist prior to its participation in revolutionary struggles, Rancière's political subject has no content prior to its participation in politics.

There are a few important implications that can be derived from these propositions. Mainly, politics can only exist in a field where political subjectivities are allowed to exist. This means that politics cannot be defined by the formal structures of the state. As Rancière notes, the political is the polar opposite of what he calls la police --- 'a term that encapsulates most of what we normally think of as politics (the actions of bureaucracies, parliaments, and courts)" (Chambers, 2011: 303). Additionally, Rancière's conception of politics goes beyond the institutionalist view of the political as a search for institutional power (whether electorally or by other means). Being "politicized" does have to mean being associated to a party or a "political" movement although these entities could well be spaces where political engagements unfold. Popular political participation cannot be equated or reduced, according to this view, to a formalistic or juridical understanding of participation, like voting, participating in workshops organized by the state, occupying bureaucratic positions in "participatory" institutions like Ecuador's recently formed Council for Citizen Participation and Social Control, being a member of parliament or a political party. Politics is not, and this is an important contribution of 
Rancière's, a formalistic term that can be equated to state forms, bureaucracies, or even political organizations.

It should be noted, however, that my contention here is not that Mouffe's and Rancière's view on politics can be necessarily equated; there are important differences between them. From Mouffe's conception of politics and the political I am trying to emphasise the contrast that she places between agonisms and antagonisms. In this sense, what Mouffe's argument stresses is that for politics to emerge there must be an encounter between opposites, or at least between differing positions, views, stances, opinions, and claims. The transition between a war-like encounter to one where conflict becomes manageable and fleshed out without violence is a central element of Mouffe's understanding of politics. In this sense my interpretation of politics and de-politicization following Mouffe's seeks to evaluate the degree the encounter between opposing forces is allowed to emerge in Ecuador.

By contrast, from Rancière's views on politics I stress two important points that are not addressed by Mouffe, but that are not, at the same time, inimical to Mouffe's views on politics. The first is regarding political subjectivities and the second his understanding of politics as the disruption of "police" orders. The question of disruption and subjectivities are important and not covered by Mouffe's "theory." In this sense, Rancière's views are useful in analyzing the role, for example, of indigenous populations' political activism and their relationship to the state. As shown in Chapter Six, for instance, the radical narratives of Sumak Kawsay emerging from indigenous populations can be understood as political precisely because of the way in which their contents seek to disrupt established 
interpretations/practices about issues like development, progress or participation being endorsed and/or reproduced by the state and the formal "political apparatus."

\section{De-Politicization}

It follows, therefore, that de-politicization would entail the elimination of the spaces, or the fields where certain political subjectivities can emerge; it means limiting the possibility for political subjects to enter into non-violent antagonisms. De-politicization entails, moreover, the process through which governmental regimes replace spaces where politics, that is, political subjectivities, are able to emerge. In other words, if there is little space for antagonisms to become agonisms, it means that a process of de-politicization is taking place. This replacement of politics with other forces is carried out through various mechanisms: the intervention of experts, the partial utilization of technical knowledges and so on. Put differently, the governmentality of the Ecuadorian state is, I argue, largely rooted in a de-politicizing thrust that seeks to turn political issues into technical ones (cf. Li, 2007a).

As Murray-Li notes, "Questions that are rendered technical are simultaneously rendered non-political. For the most part, experts tasked with improvement exclude the structure of political-economic relations from their diagnoses and prescriptions. They focus more on the capacities of the poor than on the practices through which one social group impoverishes another. This feature led James Ferguson to describe the apparatus of planned development as an 'antipolitics machine" that "insistently repose[s] political questions of land, resources, 
jobs, or wages as technical 'problems' responsive to the technical 'development' intervention.' Anti-politics of this kind is subliminal and routine (Li, 2007: 7). In similar fashion Ferguson argues, in reference to the development industry, that "by uncompromisingly reducing poverty to a technical problem, and by promising technical solutions to the suffering of the powerless and oppressed people, the hegemonic problematic of development is the principal means through which the question of poverty is de-politicized in the world today" (Ferguson, 1994: 256).

To conclude, I should mention, once again, that this dissertation's interest is not in whether the Ecuadorian state has been successful in depoliticizing social forces. This, I consider, would be a misplaced question. Clearly, no state could accomplish the full elimination of politics. The question that interests me is: what characterizes the form of rule that has emerged in Ecuador and what is its relationship to politics. One of the conclusions that my investigation has reached is that the "governmental ethos" of the contemporary Ecuadorian state is largely antipolitical. I conclude, furthermore, that an important artefact for the construction of a strong(er) state in Ecuador has been its negative stance towards politics. And finally, to end this section, I would like to make three concluding theoretical claims: first, that anti-politics/ de-politicization is regarded in this dissertation as an ongoing process that displaces politics from one arena to another, never fully eliminating it; second, and notwithstanding the previous point, the successful displacement of politics can entail the temporary or permanent demobilization of social forces and political identities; and finally, anti-politics is a modern form of rule that is rooted not in coercion and force, but in the prevalence of governmental regimes that 
penetrate society through legitimate means.

\subsection{Marginalized Populations, Governmental Regimes and Resistance to Power}

While this dissertation is about the state and ways of understanding its power manifestation in contemporary Ecuador, it is indispensible to look at nonstate actors to understand something about the state. As I mentioned in the Introduction, I am particularly interested in indigenous peoples' organizations and to a lesser degree, dissident NGOs. While my research for this dissertation was mainly conducted at the level of state institutions, programs and officials, I also undertook a series of interviews and participated (as an observer) of indigenous peoples' protests and meetings. Thus, my theoretical-methodological approach must be able to reflect the relationship between indigenous peoples and the state beyond a simple, nominalist analysis of the struggle between a marginalized group and a powerful state. Specifically, I seek to contextualize state-society relations within an analysis of modernity that acknowledges the coloniality of modern power bringing together Foucauldian power analytics, governmentality and an analysis of colonial relations through decolonialism.

Processes of state formation have to be given a specific significance according to the cultural settings in which states operate. In the specific case of Ecuador, engagements between indigenous peoples and non-indigenous peoples must be placed within the larger context of postcolonial relations and the deeply racialized and discriminatory practices that have historically defined processes of 
state formation. The Ecuadorian state, especially in its relationship to indigenous peoples, cannot be analyzed apart from its colonial past and present. Thus, in my investigation of participatory processes, especially those taking place in knowledgeintensive forums (like the PNBV workshops), I pay particular attention to manifestations of believed ethnic/racial/cultural superiority.

One of the fundamental reasons for my interest in indigenous peoples is that, along with Afroecuadorians, indigenous peoples are perhaps the most marginalized of all social groups in Ecuador. Among other things, this has the very important implication that an important part of their demands towards the state imply farreaching structural changes in economic, social, cultural and political practices of the state. As shown in the previous chapter, the "radical" nature of indigenous peoples' demands rests on a political "core." Several indigenous peoples' demands, particularly those emerging from CONAIE, like plurinationalism or interculturalism, are political in nature because they emerge as strategic narratives of contestation of the status quo. Consequently, a study of the state, especially as it comes in contact with indigenous organizations like CONAIE, must consider the question of politics and political subjectivities beyond formal aspects like representation in parliaments, ministries and/or bureaucratic posts. ${ }^{11}$

In a previous section I had mentioned the issue of politicization. Decolonial theories, as de la Cadena (2010) shows explain an additional issue regarding

\footnotetext{
${ }^{11}$ Specifically, an analysis of power that remains at the level of institutions and the formal apparatus of the state may underestimate the different ways in which colonial relations continue to be prevalent. Particularly since the government of Lucio Gutierrez and the creation of the Pachakutik party, indigenous peoples are (not proportionally of course) represented in Parliament, have numerous heads of local government, have and continue to occupy ministries and other important bureaucratic posts.
} 
politicization. Much like governmentality, decolonialism emphasizes how hegemonic orders tend to the depoliticization of certain issues. But decolonialism has a theoretical addition: its focus on identity. Decolonialism shows, for example, that indigenous peoples often are not even accorded political status; not in a formal sense but beyond it. Their political positions often do not enter in the radar of authorities as potential challenges. According to De la Cadena (2010: 343), in the battlefield of politics "decisions are taken about who the enemies are, but as important, about who, notwithstanding the antagonism, are not even worthy of enemy status. On occasions they are not even worth killing; they can be left to die because, although included in the concept of 'Humanity,' they do not count-at all, for they are too close to 'Nature'." In other words, depoliticization goes beyond the issue of making certain issues technical and leaving political decisions to technical experts; depoliticization is also about the non-inclusion, the complete dismissal and even sheer ignorance of certain issues and groups considered not worthy of the status of enemies or adversaries. In this sense, one is not so much talking about a depoliticization of some issues and social forces as about their "a-politicization." Thus, decolonialism helps us, through its emphasis on race, ethnicity and cultural identities to understand how the contours, limits, boundaries and margins of "the political" are drawn according to racialized, Eurocentric, or mestizo lines. While Foucault focused on asylums, schools and prisons, decolonials focus on races, ethnic identities and cultural formations and their power implications. Clearly these two approaches are compatible and complementary. 
Moreover, what the question of politics highlights from this theoretical perspective is the agency of marginalized populations. Decolonials emphasize the resistance potential, the critical voice, epistemic privilege (cf. Mohanty, 2003) and the political will of marginalized populations (Walsh, 2007). Drawing partly from Marxism and Gramscianism (see for instance De la Cadena, 2010; Mignolo, 2005), some decolonials center their attention on why people mobilize in opposition to power, particularly colonial power. Like Marxists, decolonials do focus on material factors and relations of production. Important political motives for mobilization include access to irrigation systems, land, territory as well as the relations of production involved in, for example, agricultural work. Unlike many Marxists, however, decolonialists consider issues of identity, including ethnic and epistemic identities as salient political issues (see for instance Walsh, 2007: 225, 232) that can lead people to mobilize. Indigenous peoples do mobilize to preserve, practice and protect their world views, knowledges and beliefs (De la Candena, 2010). Agency is ontologically conceived both at the level of material forces and at the level of identity. Agency however, is also conceived at the epistemological level. According to Walsh (2007: 323), for instance,

[t]o speak of an 'other' critical thought then is to give credence to ongoing struggles - struggles that are epistemic as well as political in character - to confront coloniality, thus marking a positioning radically distinct from that which locates critical theory simply within the histories and experiences of modernity and the narratives these histories and experiences have fostered and created. Such a shift is important for 
what it helps reveal, including the subjects left out or marginalized by much of critical theory and their socio-political and epistemic agency, but also the association between thought and social and political intervention.

Finally, an additional issue highlighted by decolonials (e.g. Quijano, 2007; Mignolo, 2001) as well as postcolonialists (Bhaba, 1995; Escobar, 1995; Said, 1995) is the colonializing effects that the discursive hegemony of concepts like "modern" "modernization" and "development" have had on indigenous peoples. The basic argument in this respect highlights how the discursive fields that developed through issues like development and/or modernization had the power effects of discredited worldviews critical of capitalist modernization, particularly that of indigenous populations. Later on in this work, when I discuss the issue of a modernizing state I am interpreting the notion of modernization precisely through the theoretical (and historical) lens provided by decolonial theories. Decolonial and postcolonial analyses of development and modernization reveal how the movement towards development automatically excluded certain voices, races, and cultural traditions (see Escobar, 1995, 2010).

Postcolonial arguments in this respect have been well rehearsed but historical conditions have indeed changed. The Ecuadorian state is more inclusive and even its Constitution has sought to break the hegemony of the development discourse. Nonetheless, as Cathy Walsh shows in an analysis of some of the economic policies and theories endorsed by the Ecuadorian state since 2006 (particularly Amartya Sen's approaches), the need for a critical decolonial outlook 
continues to be prevalent as many of the elements present in the development discourse have been transplanted to the these "new" versions of development. In similar fashion, I attempt to show in Chapter Five that the discourse-practice which defines the contemporary state, and in which its power practices can be contextualized is what I call "modernizing neo-developmentalism." This modernizing neodevelopmentalism is largely defined by many elements of the development discourse, which the Ecuadorian Constitution nominally rejects. I also argue, that it is the prevalence of this regime of discourse-practice that defines the application and use of disciplinary measures on some sectors of the population, particularly indigenous peoples and environmental NGOs.

In sum, the significance of decolonialism for my research is manifold. It helps me to contextualize the interaction between the governmental regimes and indigenous organizations as a decolonial struggle. By placing state-indigenous peoples relations within a history of colonialism, the issue of politicization acquires a more important and significant position in this analysis. Furthermore, following Anibal Quijano, (2002), it could be said that the racialization of political relations means a classification of populations according to racial and epistemic categories. The history of the Americas, Quijano contends, is largely defined by the construction of populations according to the superior-dominant (white) European and the inferior-dominated non-European. The coloniality of power means the naturalization of these relations of difference and hierarchy. The coloniality of power operates, as Walsh points out, in every plane of social, subjective and 
material life and is central to the formation of "national" mestizo societies of the Andes (Walsh, 2010: 99).

Finally, the encounter between the state and indigenous organizations must be contextualized beyond the institutional characteristics and institutional roles of actors. The researcher must be aware of the different epistemic positions of actors (modernizing neodevelopmentalist state vs. the "Other"). In conjunction with governmentality, decolonialism produces the following theoretical/methodological questions: what is the relationship between coloniality and modalities of government in the post-neoliberal state? What is the role of politics in governmentsociety, particularly in the context of a post-neoliberal state? What are the different understandings of participation held by the state? How do they differ from those proposed by indigenous peoples during the Constitutional period of 2006-2008? The conjunction of decolonial and governmentality leads the researcher to be sensitive to the continued prevalence of coloniality and to defining power relations between state and non-state actors, particularly indigenous populations. Linking these two approaches, thus, allows me to see how two different conceptions and practices of politics (the state's and indigenous organizations') come into tension with one another and ask about the consequences of this tension.

\subsection{Problems with Governmentality}

First, critics have noted that governmentality, as well as Foucauldian analyses of power/knowledge, for all their emphases on power, miss important power implications concerning colonial and ethnocentric relations of power (like 
for, example, when non-indigenous knowledge is deemed as superior not on the basis of its contentions, but on the basis of its ethnic-racial origin/source). Foucault himself has been accused of producing ethnocentric (Eurocentric) analyses (see, for example Li, 2007: 12; see also Taylor, 2009; Walsh, 2007). Second, because of the importance and characteristics of power in Foucauldian analytics (including governmentality) critics have also charged Foucauldian approaches for being unable to account for processes of resistance to power; that is, why people resist and escape specific fields of power/knowledge even if they are embedded in them.

Before I propose ways of overcoming these weaknesses, I would like to say a few things about the potentialities of Foucauldian analytics, including governmentality, beyond those formally stated by Foucault and some of his followers. On the question of coloniality, and the coloniality of power (cf. Quijano, 2007), it is important to emphasize that one of Foucault's primary concerns both theoretically and methodologically, was to look at the margins of society and marginalized knowledges and discourses. He did this because he thought that that was the best way of looking at power given power's ubiquitous but uneven presence. This meant that Foucault paid special attention to subjugated discourses, "abnormal" practices, and marginalized populations. Thus, and notwithstanding his Eurocentric phases, Foucault's view on power/knowledge leaves a number of open doors that invite analyses based on ethnicity, race and the politics of geopolitical colonial relations.

The second problem with Foucault, as mentioned earlier, relates to shortcomings in identifying theoretical explanations to account for people's 
resistance to power. Put differently, Foucauldian analytics fails to account for how and why people mobilize against power (agency). To be fair, it should be said, as Li (2007) does, that governmentality, and the works of Foucault are generally not meant to analyze political mobilization; Foucault's concern was not why people oppose power but how power defined the lives of those that came in contact with it. This is not to say, however, that through governmentality one cannot pose meaningful questions about people's resistance to power or the ability of subjects to escape Foucault's power/knowledge "trap." Governmentality, as well as Foucauldian analytics, is useful for figuring out ways in which power affects the lives of people without, as Li notes, their consent being given or withheld. Govermentality is therefore crucial to investigating the power implications of governmental techniques that are seemingly neutral, benevolent, or even emancipatory like, for instance, participatory planning. However, while Foucault, probably due to his untimely death, was unable to account for people's resistance to power, he always contended that wherever power was, there was also a corresponding field of resistance to it. In this sense, it is only fitting to extend Foucault's research program into an analysis of forms of resistance and political mobilization.

Two additional (and important) criticisms have been levelled against Foucault and governmentality. Jonathan Joseph (2010: 226), for instance, argues that "the danger inherent in the concept of governmentality is that it becomes a catch-all category that can be applied far too generally." More concretely Joseph asserts that governmentality should be directly associated both historically and 
analytically to liberal states (although he does not define what a 'liberal' state is, or when a country becomes 'liberal'). Middle-Eastern states, for instance, are perhaps better understood through the notion of sovereignty (Joseph says discipline) (the direct intervention of the state over the lives of people) not governmentality. Because the essence of governmentality is that power operates in more ways than coercion and negation, governmentality is well suited to explain liberal societies in which government operates through freedoms, concessions, self-responsibility and so on, and not states where government is conducted through the elimination, or restriction of freedoms.

Joseph's second concern is that, and I quote him here at length,

despite Foucault's own talk of the development of capitalism, the spread of political economy and a new concern for population and workforce, many of the followers of Foucault are not prepared to talk of such conditions of possibility, only of the practices of governance themselves. Here we see the final limit of governmentality. It explains a particular set of practices and techniques, but something else is required to explain the context in which these practices and techniques can best operate. Quite simply, for governmentality to be a useful concept, it must be part of a wider social ontology that can account for its successes and failures and hence the uneven nature of the international terrain ... Governmentality theorists often have what might be called a flat ontology in that they are not prepared to talk of underlying causes, processes or structures ...governmentality approaches have a tendency to focus too much on the 
mentality aspect, that is, the idea of governmentality as a nomos or political rationality. This misses out on its social, structural and institutional possibilities and limitations (Joseph, 2010: 241; emphasis added)

In a certain sense, I agree with Joseph's criticisms. Indeed, without limits, governmentality, along with discourse analysis and Foucauldian power analysis have the potential to represent an inescapable logic. If discourse/power is everywhere how can we know when and why it is discourse/power that is having its own effect in determining the conditions of possibility of a particular phenomenon or event? This is a common problem associated with post-structural approaches to political analysis: even though they seek to avoid totalizing logics and metanarratives, their focus on discourse tends to reproduce the same totalizing effects of metanarratives.

Without entering into a convoluted and overly-rehearsed metatheoretical discussion about discourse and power, I would like to rebut Joseph on a few counts. While Joseph is correct in that governmentality ought not to be separated from other social phenomena, he underplays the importance of history, capitalism and the state in Foucault's account of governmentality. This position, as I see it, almost entirely misses the importance and trajectory of Foucault's studies on power and governmentality. For Foucault governmentality is a historical phenomenon and, therefore, cannot be separated from a wider social context. In fact, the whole of Foucault's intellectual project regarding power is precisely about different power modalities in varying socio-historical contexts (a cursory look at "Discipline and 
Punish," "The Order of Things" or "A History of Sexuality" would show this clearly). Foucault always gave due importance to capitalist development and modernity in his interpretations of power, knowledge, discourse, etc.

My point is that Joseph too quickly dismisses the rich historical (and therefore thick contextual) content in Foucauldian analyses. He seems to be mistaking a focus on mentalities, discourses and ideas found in Foucauldian analysis, with a reductionist account of political life that reduces everything to the presence of these issues. Thus, I think that Joseph constructs a straw-man reading of Foucauldian analyses

A second problem with Joseph's reading of governmentality is that there is little sense, unless one comes from a foundationalist (cf. Monteiro and Ruby, 2009) and ontologically dualist (cf. Jackson, 2008) perspective (Joseph is a self-declared scientific realist - see Joseph, 2007) in separating mentalities from "structures." Structures, if defined as consistent and enduring social practices and institutions cannot be separated from the mentalities/discourses that disclose their significance to people. Joseph, I believe, makes two errors on this point. First, he seems to consider governmentalities (and Foucauldian analytics) as being exclusively about ideas (mentalities/rationalities) and words (discourses). The second is that he employs a dualistic ontology (cf. Jackson, 2008), which arbitrarily separates "structures" like capitalism, from discourses/mentalities. He implicitly separates subjects from the world in which they live - the world "out there."

With respect to the first point, it is crucially important to state that for Foucault, as for many of his followers (e.g. Jessop, 2007, Lemke, 2000, Walters, 
2012), mentalities (and discourses) imply practices - they cannot be separated. Lemke (2000: 7; emphasis added), for instance, notes that:

The first important aspect of the concept of governmentality is that it does not juxtapose politics [meaning practice] and knowledge but articulates a "political knowledge". Foucault does not pose the question of the relation between practices and rationalities, their correspondence or non-correspondence in the sense of a deviation or shortening of reason. His "main problem" is not to investigate if practices conform to rationalities, "but to discover which kind of rationality they are using" (Foucault 1981, p. 226). The analytics of government not only concentrates on the mechanisms of the legitimisation of domination or the masking of violence, beyond that it focuses on the knowledge that is part of the practices, the systematisation and "rationalisation" of a pragmatics of guidance. In this perspective, rationality does not refer to a transcendental reason, but to historical practices; it does not imply a normative judgement, since it refers to social relations.

In this passage Lemke makes clear, I believe, that governmentality implies: a) social practices as part of a wider social context; b) governmentality is about mentalities/rationalities and about practices; c) practices and mentalities (and therefore discourses) cannot be separated.

The second point, where in my view, Joseph errs, is in evaluating Foucauldian analytics from a dualistic ontology. A dualistic ontology is an ontological view that separates the subject (the 'knowing' subject) from the world "out there" along 
Cartesian lines (Jackson, 2008). This entails a condition in which reality is conceived on its own terms, separated from those who populate it, conceive it and live it, that is, from subjects. When Joseph phrases the conditions of possibility for governmentality in causal terms, he is ontologically separating structures from mentalities. This entails that there are objective structures "out there" that can be separated from the discursive practices that disclose their character to people. In other words, there are objective structures on the one hand, and discourses/mentalities on the other.

My concern here is not to refute a dualistic ontology from a metatheoretical standpoint. The issue I am raising here is that Joseph interprets Foucauldian analytics from a dualistic perspective without a proper discussion of the relationship (and possible separation) between mentalities/discourse and structures. Here it would be useful to note that as Ernesto Laclau and Chantale Mouffe (1985) make clear, discourse and structures (reality) are inseparable. Moreover, focusing on discourses (or mentalities and rationalities) has nothing to do with negating or accepting the existence of a reality outside discursive practices. There may well be a reality beyond discourse, but insofar as we think and speak about it, the real question is whether and to what degree such a reality can be constituted independently of any discursive conditions of emergence (Laclau and Mouffe, 1985). For Laclau and Mouffe, like for Foucault (inspired in Heideggerian philosophy), there is no point in separating discourses from "structures", or ideas from practices like Joseph does. Joseph therefore begins his analysis from a meta- 
theoretical position that most governmentality scholars would reject. In this sense his criticisms seem somewhat arbitrary.

It is important to note that governmentality and studies based on it, unlike Marxist approaches, emphasize the mentalities that make governing possible in specific socio-historical contexts. Like I said earlier, Joseph is correct in pointing out that governmentality must be used within certain limits and in certain contexts, but he errs in conceiving the conditions of possibility for governmentality in causalstructural terms. The very use of governmentality implies an emphasis on power/knowledge relationships and therein lies the analytical specificity and usefulness associated with govermentality. This does not mean, however, that governmentality argues that focusing on ideas, discourses or mentalities is all that is needed in order to understand governmental practices, in particular, and politics more generally.

In sum, while Foucault's theories', including governmentality's, shortcomings are important in the ways mentioned above, they can be complemented and "improved." Governmentality, I contend, is perfectly compatible with theoretical approaches that look, for instance, at colonial relations of power/knowledge (like racism, gender and/or epistemic violence) as well as questions of political agency (why people oppose power and mobilize). I consider, in fact, these questions to be organic extensions of a Foucauldian research program. In the following section I explain why this is the case. I will also present a few theoretical stances that, in conjunction with Foucauldian governmentality, will be useful for my analysis of Ecuadorian governmental techniques such as participatory 
planning. Before doing so, however, I would like to borrow Tania M. Li's words, and note that my intention here is not to produce a "super theory," or a grand-narrative akin to Michael Hardt's and Antonio Negri's Empire, rather, I, like Li, "tolerate the untidiness and tension introduced by different theoretical traditions because of the distinct questions they pose, and the tools they offer to guide my analysis" (Li, 2007a: 19). 


\section{CHAPTER THREE}

\section{A GENEALOGY OF THE ECUADORIAN STATE AND THE CO-CONSTITUTION OF STATE AND SOCIETY}

\subsection{Introduction}

This chapter provides the historical background for developing this work's main arguments. The historical approach provided here foreshadows some of the theoretical and empirical analyses provided in later chapters. In particular, and given that this dissertation is rooted in a governmentality-studies approach it provides a historical overview of the different "governmental forms" developed in Ecuador since 1830. Moreover, the genealogical stance of the dissertation is underscored by focusing on the different periods of rupture and continuity in processes of articulating and re-articulating the Ecuadorian state. In this respect it gives particular attention to the role played by social forces, especially indigenous people in shaping the state within and beyond formal state institutions. This means looking not only at indigenous people struggles but also at their epistemic claims against the state and the colonial dimensions of state power since 1830.

At the same time, however, this chapter stresses the historical-sociological dimension of the dissertation, particularly its more "Weberian" lens by overviewing the different socio-economic formations associated with processes of political and economic reform. The analytical reasoning behind this choice is to complement a governmentality approach with a "sociological" dimension more apt to analyzing "large" historical periods and structures (cf. Tilly, 1984). Thus, the chapter looks at the different periods of political and economic crises and hopes to demonstrate that 
in more than one respect, the Correista state is unique.

I argue that there are two inter-related forces shaping the relationship between state formation and organized indigenous peoples: colonialism and the persistent struggle by indigenous forces to overcome it. I show that participation by indigenous peoples has been met with opposition by the continuous prevalence of various forms of domination and that it has been most visible in the form of mass mobilizations, protests and acts of defiance, particularly during the 1990s, against a discriminatory state and national culture. At the same time, the narrative presented below interweaves processes internal to the indigenous movement to what could be called a historical sociology of the state. It shows the historical trajectory of participation by indigenous peoples in relationship to the most salient events in the state's political and economic history, particularly since Ecuador's return to democratic rule in the late 1970s. From a genealogical stance I show that indigenous struggles have been a salient factor in the history and articulations and rearticulations of the Ecuadorian state.

Finally, as mentioned in Chapter One, this Chapter also develops a historical overview of the first period of the Correista state, the 2006-2007 period. The central objective of this analysis is to highlight the relatively politicized character of the period (relative to the post-2008 period). Specifically, it argues that the basic ruling ethos of the state allowed for more openings for political contestation and that the anti-political ethos of the Correista state is more clearly seen in the post-Constituent period of 2008-2012. 


\subsection{The State, Participation and Social Forces in Historical Perspective}

In the early hours of June $6^{\text {th }} 1990$, Andres Guerrero (1997: 1) writes,

[A] man in his late forties (a white-mestizo man, thus, a member of what I have called in other works "citizen in the practical sense") turns on his television set, while, as usual, having his morning coffee and milk; in between sips, he follows, from the corner of his eye, the news. But this morning there is something unforeseen; surprised he cannot stop watching the television; he's left in awe and deep in thought. He discovers an unimaginable social fact for Ecuadorian public opinion of the latter part of the previous century: groups, multitudes of women, men and children dressed in ponchos and anacos [traditional skirts] invade the panamerican highway and place barricades; they shut off the entrance of various cities; they walk the streets and plazas of capital cities of the highlands: they demand the presence of state representatives, for them to be heard and to negotiate. They are indigenous peoples. They count themselves in the hundreds of thousands, a million, perhaps even more; they protest in public spaces; they manifest themselves: they speak. Days after, I found my friend still unsettled due to the images that he discovered in the screen of his television set that morning. He tells me: "imagine, I considered a fact that no indigenous peoples were left in the country and find through the television, that there are millions; they come out of everywhere; they live in misery" 
This anecdotal image provided by Guerrero is powerful in a number of respects. It conveys the cleavage between mestizo society and indigenous populations as well as the sense of marginalization in which indigenous peoples remained since 1830. Indeed, indigenous peoples, it is well documented, have been marginalized and discriminated through diverse mechanisms: legal exclusions from public institutions (limiting their right to vote, for example), racism, physical repression and exploitation. But Guerrero's is an image of invisibility as much as it is of exclusion. As he notes, much of the indigenous populations of Ecuador were not only excluded, but also made invisible through liberal regimes of citizenship that recognized formal equality while eschewing deep structural and cultural inequalities between populations inherited from the colonial period (Guerrero, 1997, 2010). Hence, it could be said that between 1830 and 1990, for all practical purposes, indigenous peoples in Ecuador lacked meaningful political and bureaucratic representation within the state and participation in public policymaking was largely nil aside from the indirect effects of their mobilizations.

Partly following Mary Crain (1990: 45-55) I would like to divide the historical relations of indigenous peoples and the state as well as processes of state articulation and rearticulation between 1830 and 1990 in the following way: The National Period: Creole Elites and the Constitution of Indian Others, 1830-1949; the Transition period: 1950-1978; and the period of Redefining National Identity and the Construction of the New Citizen,1979-1990. While Crain's argument is specific to the construction of national identity and not state formation, I find her historical periodization relevant: Processes of state formation have been directly linked to the 
presence and activity of indigenous populations and the different challenges that they have presented for the state. The Ecuadorian state has been constantly challenged and redefined in the process of dealing with the indigenous "issue." There are three additional periods prior to the articulation of what I call the Correista state worth noting: the return to democracy and the birth of neoliberalism in Ecuador, the apogee of both the indigenous movement and the peaking of neoliberal reforms; second, the crisis of neoliberalism; and third, the relative decline of the indigenous movement.

\subsection{The National Period: Creole Elites and the Constitution of Indian Others: 1830-1949}

The Ecuadorian state was founded in 1830 after a successful decolonization war from Spain. The Ecuadorian state of the 1800s is described by Ecuadorian historian, Enrique Ayala Mora (2008: 74), as an "oligarchical landowning state" largely organized around the Hacienda ${ }^{12}$ system. Similarly, Benjamín Carrión (1957) shows that the early Ecuadorian state could be best characterized as a privatized entity "captured" by elites defined in terms of both, the accumulation of material resources (mainly land) and their membership to a small creole aristocracy. Consequently, the early state was defined by its exclusionary practices based on racialized hierarchies inherited from the colonial period, as well as political and economic inequalities. In general terms large landowners generally

\footnotetext{
${ }^{12}$ Haciendas are large agricultural estates around which production was organized. However haciendas also represent a feudal-like system for the organization of labour-patron mainly indigenous peoples' labour. Haciendas were also important for political power as citizenship was restricted according to property and social class and ethnic background (which in Ecuador is not only a historical-materialist concept but and identity, racially-based one).
} 
coincided with a Europeanized elite that responded to material (land, production) as well as identity (European, white) factors. In this sense the resulting state form could be more appropriately called an apartheid oligarchical landowning state.

An important defining component of the oligarchical land-owning State was the hacienda system. Haciendas were large landholdings around which agricultural and livestock production was organized. The hacienda system was a feudal-like mode of production ruled by colonial elites of European descent (De la Torre, 1996). The hacienda system, which was arguably prevalent in Ecuador until the 1950s is significant for various reasons: first, it makes evident that a modern state form is a relatively recent phenomenon. Second, it suggests that as far as a modern state existed it was rather limited in scope and reach. Haciendas can be defined as a premodern, private form of government/administration of populations and production (Guerrero, 2010). It was haciendas rather than the state that defined in large numbers social, political and economic relations. Haciendas were, for example, in charge of forms of taxation, the administration of justice and even the formation of local armies (see Carrion, 1984; Ayala Mora, 2008). There was, moreover, a close link between the church and haciendas, turning the hacienda system into a culturally significant apparatus (Thurner, 2000; Waters, 2007). In sum, the hacienda system, it could be argued, was a system of parallel governmental regimes that coexisted with the formal state and that made evident the weakness of the state's capacity to articulate itself as both image and practices in the national territory.

During the National Creole period, particularly in the early $20^{\text {th }}$ century, indigenous peoples' struggles were largely linked to the actions of the communist 
party and the Federacion Ecuatoriana de Indios (FEI) and the indigenista movement (Yashar, 1999, 2005; Becker, 2006), although indigenous resistance, as Ayala Mora shows, have been a constant in Ecuadorian history even in the very early stages of state formation (Ayala Mora, 1991). Indigenous peoples demands, including FEI's, centered on "the improvement of conditions under, and eventual abolition of, the hacienda system, for access to land, and for education" (Martinez-Novo, 2011: 4; see also Arnold, 2009 for an interesting case in Bolivia). It must be remembered, as mentioned earlier, that the hacienda system not only meant a way of organizing labour and production in the highlands but also signified the capturing of political power and state control by large landowners, mainly of European descent.

In this sense indigenous opposition to the hacienda system was also a challenge to the state and its organizing principles and governmental regimes. As Crain notes, the state during this first period was characterized not only by its linkages to the hacienda system but also to a corporatist state that defended the very narrow economic interests of a dominant class (mainly male, large landowners of European descent) (Crain, 1990: 45). In view of the theoretical approach of this dissertation, it should be said that the power modality with which rule was exercised at the time was a colonial governmentality (cf. O'Malley, 1996) and in some sense to Foucault's analysis of sovereign power during the European monarchical period of the $17^{\text {th }}$ century (See Foucault, 1995: Chapter One). Indigenous peoples were regarded not as subjects of improvement but as essentially different (inferior) and that difference was dealt with through coercive power over their livelihoods. Mobilizations by indigenous populations were, thus, generally met 
with repression. As Crain puts it

The creole elites were fearful of the consequences of mass participation ... Their actual rule, which was guided by strong men and repressive measures, reflects this fear of popular mobilization ... During this period a relatively unified national self was constructed in opposition to an inferior indigenous other (Crain, 1990: 46).

Indigenous peoples have been, at once, relegated from formal processes of state-formation and reproduction and yet crucial for them. This is one concrete expression of Migdal's (2004) notion that sates and societies are co-constitutive. In the first period, of state formation indigenous populations served, in part, as a negative image against which state developmental projects would be imagined - the less indigenous the more "developed."

During this period an incipient form of liberal governmentality had begun to emerge in Ecuador (cf. Guerrero, 2010). At the turn of the century Ecuador underwent one of its important political transformations in the form of what is often referred to as its "liberal revolution" (1895-1912). Led by General Eloy Alfaro, some of Ecuador's political and social structures were transformed according to the tenets of modern liberalism. Most notably this period witnessed the separation of church and state, the creation of secular schools, freedom of religion and the partial expansion of civil and political rights (Pareja Diezcanseco, 1996). However, the liberal "revolution" was largely an elitist project: a top-down struggle between conservative and liberal elites and the notions of liberty, justice and equality were upheld rhetorically but practiced in highly uneven terms (Guerrero, 1997, 2010). 
Moreover, Ayala Mora (2008: 95) points out that "the liberal revolution found its limits in those of its own protagonist [General Alfaro]. That is, it was determined by the interests of the bourgeoisie that did not undo the large landowning structures of the highlands as well as the regional power of large landowners" (Ibid.)

Alongside the liberal revolution Ecuador embarked upon the early stages of its most important nation-building strategy, mestizaje. Mestizaje could be defined, simply, as a nation-building strategy based on the notion of cultural (and racial) mixing. It is also a narrative centered on the notion of national unity through the mixing of races and cultures (indigenous and Spanish). Thus, "mestizos" at a very basic level can be defined as peoples of mixed cultural and racial heritages. At first glance mestizaje would appear as an obvious form to unite diverse populations. Nonetheless, mestizaje is defined in relation to the mixture of hierarchically uneven cultures: mestizaje as practiced in Ecuador, ignores the unevenness in the power of the cultures that it is supposed to represent: Spanish and indigenous cultures (cf. de la Cadena, 2007; Walsh, 2009). In other words, superior values were associated with whiteness and "Spanishness" (Eurocentric) while inferior ones associated with dark skin and indigenous cultures (Walsh, 2009; cf. Rojas, 2002).

Viewed from the perspective of Foucauldian view of knowledge/power relations mestizaje as a national formation strategy was intimately linked to efforts made by the state to modernize its social and economic structures along Eurocentric, modern and uneven lines: modernization and development were automatically associated to the notion of whiteness and a sense of Europeanized culture (Escobar, 1995; cf. Adoum, 1998; cf. Echeverria, 2010). The question of 
mestizaje is also relevant for my arguments here because it discloses a dimension of nation-state building in Ecuador that is intimately related to and representative of colonial structures (see Stoller, 1995, 2002). As I discuss in below one of the interpretative contexts in which governmental regimes-indigenous peoples relations is colonialism and coloniality.

Following the liberal revolution, during the early stages of a "mestizo state," between 1912 and 1950 there were cycles of economic booms (mainly due to agroexporting price hikes) and busts (mainly due to collapses in the prices of international primary goods) (Larrea and North, 1997) as well as a series of political crises. Political and economic crises were, of course, also characterized by the mobilization of social forces in opposition to the continued prevalence of an oligarchical system rooted in large landholdings and reproduced through an unequal citizenship regime. In this respect, it should be noted that an important aspect about the Ecuadorian state, particularly in relation to its processes of crisis and reform is the enactment of new constitutions. Thus far Ecuador has had, since 1830, twenty constitutions.

In sum, it is important to note that despite important social changes promulgated or triggered by constitutional reforms/changes (e.g. the expansion of citizenship rights and the separation of church and state implemented by the Liberal Constitution of 1906), constitutional changes were incapable of fostering true structural transformations in socio-cultural or politico-economic relations: Ecuador up to this day, continues to be a deeply unequal society characterized by important social, economic and cultural cleavages and hierarchies. Constitutional and legal- 
institutional changes, moreover, have been consistently incapable of generating processes of political stability and democratic institutionalization. From a historical perspective, therefore, it becomes imperative (as I do in this dissertation) to go beyond institutionalist explanations to account for the continuous prevalence of certain power relations and processes of co-constitution between state and societal forces.

\subsection{The Transition period: 1950-1978: The Incorporation of Indigenous Populations into a National Project and the Emergence of Modern Forms of Rule}

By the end of the national creole period indigenous protests and challenges to the status quo began to reach a much wider audience, leading to the reformulation of some of the legal and institutional structures that directly affected indigenous peoples (Crain, 1990; Korovkin, 1992, 1997). In particular, legislations such as the Labour Code, the Law of the Peasant Cooperatives, Communes and the Juridical Statute of Peasant Communities, were drafted during this period (Ayala Mora, 2008). This stronger presence of indigenous populations coincided, nonetheless, with the partial and gradual incorporation of indigenous populations into a state-led national development project (Crain, 1990; cf. Escobar, 1995). This partial "incorporation" is related to the development of more modern forms/modalities/techniques of rule and power, including Foucault's account of disciplinary power (as indigenous peoples enter "join" national development programs they also become subjects of institutionalized disciplinary practices to turn them into workers and productive resources) (Argones, 1985, Crain, 1990; 
Foucault, 2000) and the strengthening of the state's governmental regimes.

It could be argued that the Ecuadorian state historically has had a number of historical forms since 1830. Some of these are: the hacienda/gamonal, the militaryauthoritarian, the clientelistic, the rentier, the developmentalist and the liberal and neoliberal states (Carrion, 1984; Ayala Mora, 1991, 2008; Silva, 2005; Hurtado, 2006; Correa, 2010). All of these state forms represent state-society relationships and say something about the exercise and type of state power. The gamonal/hacienda state for example, was characterized, as mentioned before, by a type of power akin in some senses to what Foucault understanding of "sovereign" power during monarchies as well as and expression of colonial governmentalities (cf. O'Malley, 1996). The reasoning behind this assertion is that, particularly in the hacienda system, indigenous populations and peasant populations were linked to the hacienda owner by similar principles (although with important differences) to the relationship between monarchs and feudal lords to their subjects. Monarchs exercised power through the administration of death, punishment and embodied the state. In similar fashion the hacienda owner, while unable to legally end the life of his subjects, was able to control their livelihoods through systems like the huasipungo ${ }^{13}$ and/or economienda or even corporeal punishment (De la Torre, 1989; Ayala Mora, 1991; Guerrero, 2010; In the hacienda system, the hacienda owner embodied the power of the feudal state (De la Torre, 1996).

At the same time the state and its formal governmental apparatus was

\footnotetext{
${ }^{13}$ Huasipungo was a system of labour relations in which the hacienda owner allowed indigenous peoples to live in small plot of his land in exchange of the labour of the indigenous family. This resulted by and larg into a life-long debt for the indigenous family. For all practical purposes the hacienda lord owned the lives of indigenous families living under the huasipungo system.
} 
largely characterized by its inability to "penetrate society," through programs, regulations, taxation schemes and so on, giving private agents, particularly hacienda owners, the ability to govern populations according to a racist system of ownership of their livelihoods (see Guerrero, 1997, 2010). In other words, the Ecuadorian state, as both image and practices, up until the 1950s, had been largely absent from its own territory - its governmental regimes were weak and limited in reach. Evidence of this is, for example, the fact that the civil registry in Ecuador was created during the liberal revolution in the early 1900s and that the first population census was not undertaken until 1950 - one hundred and twenty years after its independence (Clark, 1998; Ayala Mora, 2008). In other words, the first attempts to develop knowledge about populations that would enable the formation of governmental interventions in Ecuador was undertaken nearly a century after its independence. This means that the constitution of modern governmental regimes was in its infancy until the 1950s. It is worth clarifying that I have found little evidence that unequivocally suggests that the state was absent in all of its forms from its own territory. The point here is that it was absent as a governmental form of rule.

There are no systematic and specific studies about the degree to which the Ecuadorian state generated knowledge in order to govern, how it did and through which governmental agencies. Nonetheless, the fact that the first census was undertaken in 1950 suggests that prior to 1950 knowledge production by the state was rather limited. As studies in governmentality (e.g. Gordon, 1990; Dean, 1999; Walters, 2012) suggest, the modern state and modern forms of power are 
characterized by the production and dissemination of knowledge, particularly knowledge about populations - the state shapes populations through the knowledge it produces about them. Hence, prior to 1950 there was little knowledge about populations and thus little possibility of generating governmental regimes capable of "penetrating society." Admittedly, prior to 1950 there had been some attempts to create governmental agencies capable of producing knowledge about populations, but the 1950 census is not only the first general population census, it is also the first census that produces the first general map of Ecuador and the first economic development study, but also the first statistical project to be linked to a governmental development plan (Hoy, 2010: http://www.hoy.com.ec/noticiasecuador/a-60-anos-del-primer-censo-444303.html).

There are a few other aspects about the 1950 census that are worth mentioning. The first is that it takes place during the presidency of Galo Plaza Lasso. The state during Plaza Lasso's presidency is one of the first since the liberal revolution of 1895 to display the partial signs of a "modern" state through the partial rationalization (cf. Evans, 1995) of the state apparatus. Second, it takes place at a time when, as mentioned above, mestizaje was the nation-formation paradigm. Kim Clark (1998) conducted a detailed analysis of the 1950s census and its relation to national identity formation. An interesting aspect regarding the census revealed by Clark's study is that it was seen as an attempt at "conquering the national territory administratively" (Clark, 1998: 196). Clark also reveals the fact that, up until that point, the state had not penetrated much of the Andean region, particularly indigenous communities. Clark cites a census organizer: "the 
enumerators will have to scale towering mountainsides and conquer uneven terrain until they locate the last living being in those remote Andean localities"; and then another: "we have used all of the means available to us to conquer the impermeability of the indigenous stratum" (Clark, 1998: 196). Following the 1950s census Ecuador has undertaken censuses in 1962, 1974, 1976, 1982, 1990, 2001 and finally, 2010 under the Correista state. Clearly, as seen from this perspective, up to the 1950s Ecuador's was a limited/weak state. The 1950 census began to mark the relative transition to a more complex state apparatus capable of extending its presence into more areas of the country.

By the 1960s the influence of haciendas had been diminished. In part this was due to the replacement of private forms of administration of populations by state-based ones, particularly, through economic interventions (Korovkin, 1992). This change in the governmental character of the state took place in a context of relative stability during the1950s. Some of these interventions, particularly in rural areas were undertaken under the auspices of the Ecuadorian Institute of Agrarian Reform and Colonization (IERAC), which is another governmental agency whose work reveals the vicissitudes and "realities" in the construction of governmental regimes in Ecuador. One of the central objectives of IERAC was to let private individuals expand, largely through their own devices and criteria, the agricultural/territorial frontier in Ecuador through a "colonization" process that entailed clearing out primary forests and native vegetation in exchange for property rights to the cleared land (Argones, 1985). This policy suggests two issues: that a private administration of territory (as opposed to populations) was prevalent and 
second that all the way to the 1980s when the policy in question was eliminated, the state was largely absent in any direct sense from its own, largely rural, territory (Ibid.). This policy of internal colonization continued through the advent of the first developmentalist state in the 1970s. Inspired by the structuralist doctrine promoted by ECLAC, the military government of the 1970s also sought to "penetrate society" through land reform and used IERAC to accomplish it. Land reform, however, was an overwhelming failure and the presence of the state in the rural sector, despite efforts of the military-authoritarian governments of the 1970s, was highly limited

In 1970s when the first manifestation of an authoritarian developmentalist state appeared. ${ }^{14}$ There were various elements that coalesced to allow for its emergence. First, the discovery of petroleum; second the international political economy and the discourses emanating from it, particularly the influence of structuralist thinking and knowledge emanating from the Economic Commission for Latin America and the Caribbean (ECLAC); and third, the authoritarian appropriation of political power by the military. As I discuss in a later chapter, developmentalist states have, historically, often been accompanied by periods of authoritarianism (Woo-Cummings, 1999). While the case of Ecuador is different from its counterparts in the Southern Cone, most notably, Argentina and Chile, the military governments of the 1970s (1972-1979) were authoritarian nonetheless. In this sense, there was relatively less negotiation and tolerance of opposition forces,

\footnotetext{
${ }^{14}$ Some point to the 1950 s and the government of Galo Plaza in this respect. I, however, refute this thesis on the basis that in the 1950s there was a highly limited knowledge base in the state capable of generating widespread state interventions. As I mentioned, only in the 1950s did the state begin to generate enough knowledge about its population. Also, the relative degree of industrialization and policies like ISI were much more prevalent in the 1970s than in the 1950s.
} 
giving the state more room to act though programs, policies and projects. There was also, as I said, more money to do it and a strong discourse emanating from the developmentalist works of ECLAC.

By the 1970s a very important event took place in Ecuador: the discovery of petroleum in the Amazon region of the country. The discovery of petroleum meant a few things. First, the relative importance of landowning elites diminished because the state focused largely on industrialization. It also meant that a new middle class developed in the main cities of Ecuador, a process that is largely linked to regimes of development (Larrea and North, 1997). At the same time the discovery of petroleum, which in Ecuador is a public resource (petroleum belongs to the state), exacerbated the rentiering tendencies within the state: the state no longer needed to negotiate with the private sector in order to generate foreign exchange; it could get it by directly selling petroleum to foreign buyers. This meant that the state had no real incentive to turn earnings into productive processes, although, at the same time the military regimes of the 1970 s were characterized by their productive, although not always efficient investments (see Argones, 1985; Correa, 2010). Petroleum earnings, however, were directly used by the state both "to satisfy elite interests and to attenuate social conflict by responding to the demands of most politically mobilized urban sectors without altering the fundamental patterns of land and asset distribution" (Larrea and North, 1997: 924).

In addition, the 1970s were, in important ways, characterized by the influence of structuralism from the ECLAC/Prebisch school of thought. During the military dictatorships of the 1970s, the state became heavily involved with the 
productive sector, particularly manufacturing industries. Import substitution industrialization became one of the central economic policies of the period. While enabling growth in industry and an improvement in some social indicators, the implementation of import substitution industrialization experienced a number of problems: manufacturing became highly dependent on imported inputs, thus contributed to the national debt; it lacked vertical integration and focused on the production of non-essential goods for high-income urban groups (Larrea and North, 1997: 919; Correa, 2010).

Meanwhile, the agricultural sector became stagnant. Between 1975 and 1982 the production of peasant crops fell sharply. As Carlos Larrea and Liisa North point out:

In general, agriculture, where employment opportunities could have been generated at low cost, was prejudiced by a 'lack of basic rural infrastructure and its unequal distribution in favour of the large producers' while peasant producers suffered from worsening terms of trade, reinforced by state price and subsidy policies. In 1978 per capita subsidies to urban sectors were almost 11 times those available for rural sectors, and among rural producers the modern sector received almost eight times more support than the traditional sectors which was composed largely of indigenous highland peasants (Larrea and North, 1997: 920). 
Hence, the developmentalist state of the 1970s was characterized by its interest in large-scale industry development and the development of an urban middle-class at the expense of rural and indigenous small-scale producers.

In addition to the economic realities of the 1960s and 1970s just pointed out, there are a few specific changes that are worth mentioning: an important effort (in comparative historical terms) at agrarian reform; further reforms to the labour code leading to the formal elimination of servile labour; and in 1978, the universalization of suffrage (as mentioned earlier, illiterate people could not vote in Ecuador until 1978) (Andrade, 2010). Hence, in 1978 indigenous peoples became a population that was able to affect the outcomes of elections ${ }^{15}$ - a change that has since affected the relationship between the state and indigenous organizations and peoples.

This included, for example, the formalization of indigenous peoples under civil registries, "counting" indigenous peoples as populations capable of, for example, being counted as workers in processes of labour commodification. Partly this became possible as a result of the various censuses that was conducted in 1950 . Between 1950 and 1979 four population censuses (see above) were undertaken. The increasing complexity of state-society relations emerging from, among other things, changes in the country's discursive and cultural structures and in its political economy demanded changes in the state apparatus. Hence one can observe the creation of "an increasingly complex juridical and administrative apparatus. New Ministries and other public entities, including a dozen public corporations were born during this period" (Waters, 2007: 125). Amongst these institutions was the

\footnotetext{
${ }^{15}$ Voting is obligatory in Ecuador.
} 
IERAC. It is in this period that the governmental power of the state begins to reach areas of its territory that it had previously left unattended (Waters, 2007).

At this time, it worth stressing, important dimensions of the state's rule were defined by the fact that the military had been in power since the early 1970s. It could be argued that at least two different state forms coexisted during the 1970s: an authoritarian, a developmentalist and an oligarchical state. But, it should also be noted, power through coercion can only take the state so far. The developmentalist state of the 1970s was characterized, like the current one, by relatively high attention paid to knowledge production (relative to previous state forms). New maps, new universities, and new statistical projects were undertaken. For example, the Institute of National Statistics was created in 1973; the state operated through a more intensive expansion of knowledge-based, developmental governmental regimes (Cf. Dean, 1999; cf. Elden, 2007). It is here that one can observe the development of a more articulated state and the further unfolding of governmental techniques of rule. The end of the 1970s also marks the end if military rule, the return to democratic rule and the very early stages of neoliberal reform.

In sum, it is important to note that despite these efforts, the paradigm of a mestizo nation was not abandoned. The extent to which indigenous peoples were "incorporated" into national development processes was as a marginalized group, as workers, not as distinct socio-cultural groupings with their own political, social, cultural and epistemic cosmovisions and forms of organization. Also important for understanding the "incorporation" of indigenous peoples into a national state-led project is the state's efforts at the end of the 1970s to develop a stronger 
agricultural and industrial sector and broaden the country's labour base (wage labour) (Argones, 1985).

\subsection{The Construction of The New Citizen, the Early Neoliberal State and the Birth of CONAIE: 1979-1990}

By the end of the 1970s the military dictatorship ruling Ecuador faced a series of challenges and finally decided to lead a highly controlled transition into democratic rule. Elections were called in 1978 and progressive candidate Jaime Roldós was elected president. Roldós and Vice-President Osvaldo Hurtado billed themselves, as Crain (1990: 48) puts it, as the first government in Ecuador's history to have been democratically elected without the support of the military and/or the national oligarchy. Moreover, as mentioned already, the 1978-79 was the first election in which illiterate Ecuadorians were allowed to vote. This fact, in addition to Roldós's progressive electoral platform, meant a more active effort at incorporating indigenous symbols and certain aspects of their cultures into the national culture.

Roldós's presidency was initially characterized by hope in the ability of the state to correct some of the problems mentioned earlier: unemployment, poverty, inequality etc. Throughout Roldos's presidency the state continued to be an active agent in restructuring social, political and economic structures (Argones, 1985). However, Roldós's promises proved short-lived as he died in a plane crash in 1982. Roldós was replaced by then vice-president Osvaldo Hurtado. In contrast to Roldós, Hurtado was a right-leaning politician and his presidency could be characterized by 
the bringing about the early stages of neoliberalism (Correa, 2010). Hurtado's presidency was characterized by a series of economic crises linked to the increasing power of a banking and commercial elite aligned with the state. One of the most important historical events in this respect was the process of "sucretización."

Sucretización is the process by which the state acquired the private sector's (mainly industrialists') debt in dollars and converted it into sucres (Ecuador's currency until 1999). This meant that the money owed by private agents in Ecuador to foreign banks was now public debt. In other words, the state was now in debt, in dollars, to private banks abroad and the clients of those banks now owed the state but in sucres and in more advantageous conditions (Correa, 2010). Overall the state converted almost 1.300 million dollars into sucres, which effectively meant a subsidy to the private sector amounting to about 650.000 million sucres (over one billion dollars, at the exchange rate of 600 sucres per dollar, which for 1983 was a significant amount), only considering the differential of effect of the exchange rate (Acosta, 1990: 307). The sucretización of private debts signalled the linkages between the state and private economic elites - a relationship that grew with neoliberalism and that eventually led to the nation's economic collapse in 1999.

On the political side the process of change initiated in 1979 meant the return of democratic party politics. The new institutional arrangement (the 1979 Constitution) privileged the return of a multi-party system. As Simon Pachano (2007: 43) notes, parties were supposed to be the "main and, practically, the only political actors, and for that reason they were given a monopoly over political representation." Thus, the 1979 elections witnessed the return of traditional parties, 
like the socialist party, and many others like the Partido Social Cristiano (Christian Democrats - right wing), Izquierda Democratica (Social Democrats - centre left) and Concentracion de Fuerzas Populares (Concentration of Popular Forces - populist party) and later, after Roldos's death, the Partido Roldosista Ecuatoriano (populist). Ecuador's party system was highly fragmented (Conaghan, 2009) and poorly institutionalized (cf. Mainwaring and Torcal, 2005). Nonetheless, the 1979 elections signalled the beginning of a period of eighteen years of interparty competition. In the period between 1979 and 1996 there were five Presidents: Jaime Roldós (leftleaning populist, 1980-1982), Osvaldo Hurtado (centre-right, 1982-1984), Leon Febres Cordero (right wing, 1984-1988), Rodrigo Borja (centre-left 1988-1992) and finally, Sixto Duran Ballen, (centre-right, 1992-1996). As shown, and setting aside Roldós's death, the four-year constitutional period for presidents was respected.

There is an additional historical issue during this period that needs to be addressed: the birth of CONAIE. The emergence of CONAIE along with the beginnings of neoliberalism are important determinants for understanding the trajectory of the Ecuadorian state prior to 2008. CONAIE was formed in 1986 out of the union of two regional indigenous organizations: the ECUARUNARI (indigenous organization of the highlands) and the CONFENIAIE (indigenous organization of the Amazon Region) (Zamosc, 2007). Perhaps one of the most significant aspects of CONAIE is its concern for "livelihood and citizenship" goals:

The former have focused on economic improvements, education, health, and the protection of Indian lands; the latter on the redefinition of Ecuador as a plurinational state, the end of discrimination, territorial 
autonomy, representation in state institutions, control over education and development programs, and official recognition and funding for the indigenous organizations" (Zamosc, 2007: 9).

I would add to Zamosc's interpretation that the "identity" and "cosmovisions" dimensions to indigenous political activism entered a new, perhaps more important phase, through the creation of CONAIE. This "identity" aspect is significant for a number for reasons. First, as mentioned before, the idea of an "indigenous" struggle, as opposed to a peasant or landless movement struggle, became a mechanism for establishing equivalences between different indigenous demands. In particular, CONAIE and the indigenous movement embraced the concept of "nationalities" to define both the unity of their struggle and the diversity between and within indigenous groups. A central demand by the indigenous movement since the 1980s, thus, has been for the state to recognize that the different indigenous groups are in fact nations (CONAIE, 2014: http://www.CONAIE.org/sobre-nosotros/historia).

It is worth remembering that there is no uniform category of "indigenous peoples" in Ecuador. There are differences in languages and in the way in which different indigenous communities relate to land and to (re)productive resources. Ecuador is a diverse country both culturally and ecologically. It is composed of four main regions: the Galapagos archipelago, the coastal region, the highlands and the Amazon region. For example, water and irrigation may be a preponderant demand of indigenous peoples in the highlands, while it is less so for indigenous peoples in the rain forest. Likewise, protecting water supplies from petroleum exploitation waste is an issue that concerns indigenous peoples from the Amazon more directly 
(as petroleum is more or less exclusively extracted from that region). Hence, contextualizing indigenous struggles from the perspective of resource-specific and region-specific realities as well as in a more encompassing sense of indigenous unity through the concept of indigenous "nationalities" had important impacts in the organizational strengths of indigenous populations (Andolina, 2003). This unity particularly in the, notwithstanding periods of internal divisions, turned CONAIE into a national indigenous organization that currently represents between 100.000 and 150.000 indigenous families (Ospina, 2009: 124).

The second crucial aspect of the "identity" period, and perhaps more importantly for the purposes of this work, is the challenge presented by the marginal, but radical narratives about the need for a civilizational challenge (Leon, 2011) made by indigenous peoples, through CONAIE. These are direct challenges against the various forms of colonialism of dominant society, particularly its epistemic colonialism (see Schiwy, 2002). Specifically, the power practices of modernity, which exclude epistemic diversity and that result in the consistent exclusion of non-capitalist, non-Eurocentric knowledge practices (Schiwy, 2002, 2010; cf. Quijano, 2004; cf. Rojas, 2001, 2007). Thus, rooted in concepts such as epistemic diversity, decolonization, plurinationality and pluriculturality CONAIE challenged the status quo from an entirely different perspective, one that demands the rethinking and questioning Ecuador's economic, cultural and socio-political structures. It should be said that while some of these concepts were already part of indigenous peoples' struggles prior to the creation of CONAIE, CONAIE's leadership and the intellectuals (indigenous and mestizos) linked to the organization made 
these issues prominent. (Becker, 2008; cf. Macas, 2010, 2011)

It is worth stressing the fact that the "civilizational change" proposed by CONAIE, goes beyond the notion of a paradigm shift in development practices or a Marxist-inspired revolutionary change. It implies a shift in the narratives about, as well as changes in the regimes of practices that accompany prevailing notions of what it means to be developed, how to achieve "development", how to organize politically in more participatory ways and how to relate to the natural world. It stresses the need to rearticulate the relationship between people and natural beings; in other words, looking at earth beings beyond the concept of resources (De la Cadena, 2010). At the same time, as Zamosc (2007) points out, traditional demands such as fair and equitable labour practices, land redistribution, control over education, the preservation of their languages, ready access to credit to work the land and so on, continued to be present in the demands that indigenous peoples pressed on the state.

Although I will speak about this in more detail in Chapter Six, I should mention that the end of the 1980 s also witnessed, due in large part to indigenous mobilizations, the creation of autonomous institutions within the state apparatus, like the National Directorate of Intercultural Bilingual Education (DINEIB). The DINEIB was an autonomous institution dedicated to implementing educational policies in indigenous communities. The creation of the DINEIB is a concrete institutional change that not only modified the state, but also reflected the growing strength in the organizational structures and the mobilization capacities of indigenous peoples. In 1988 through the creation of DINEIB indigenous peoples 
began to gain a moderate degree of control over policy-making in education (Martinez-Novo, 2011).

\subsection{The Apogee of CONAIE and the Indigenous Movement, 1990-2002 and the Peak of Neoliberal Reform}

By the end of the 1980s, as suggested above, the indigenous movement had acquired, from a historical viewpoint, unprecedented levels of organizational strength and had been able to penetrate the formal institutional apparatus of the state while keeping important levels of autonomy from local political and economic elites. As the quote from Guerrero provided at the beginning of this chapter suggests, the indigenous levantamiento (uprising) at the outset of the 1990s shook the collective consciousness of the country in an unparalleled way. Partly as a result of the changes triggered by this mobilization Deborah Yashar has called Ecuador's indigenous movement the strongest in the Americas (Yashar, 2005). All of a sudden, in the late 1980s and early 1990s, indigenous peoples and their struggle were a national issue (Guerrero, 1997). In 1990, led by CONAIE, indigenous populations staged an uprising, which was, as mentioned above, not only unprecedented for non-indigenous peoples, it was also the largest and certainly one of the most significant indigenous uprisings in Ecuador's history. The politico-economic context at the time was marked by the prevalence of neoliberalism and it was during the 1990 uprising that the demand for a plurinational state became the centerpiece of the indigenous movement's, particularly CONAIE's, demands on the state.

With the election of Sixto-Duran Ballen in 1992 Ecuador finally catches up to some of its Latin American neighbours and begins to deepen its process of 
neoliberalization (Correa, 2010) - a process that lasted until 2007. Duran Ballen's main objectives were well known neoliberal recipes that were presented to the general public as elements of the modernization of the state. The issue of "modernizing" the state was largely a question of constructing an image of the state as an agent of progress but as Simon Pachano (2007: 13) notes it also meant, "reduction in the administrative apparatus [of the state], deregulation and decentralization." Modernizing narratives about the state, thus, cannot be separated from the application of neoliberalism and the liberalization of markets, privatization projects, macroeconomic stability and cutting spending in social services. But like in other places in Latin America at the time, deregulation, state-shrinking and liberalization would inaugurate a new period of political instability as well as popular effervescence (See Conaghan and Malloy, 1994). Between 1996 and 2007, for example, Ecuador had nine presidents and two different constitutions (and a third one coming in the year 2008), a major economic collapse and the adoption of the US dollar as its new currency.

The "beginning" of the political and institutional crisis of the state during the 1990s can be more directly traced to the presidency of Duran Ballen. However, it was not until the presidency of Abdala Bucaram in 1997, that a multi-level crisis of the country acquired dire proportions. Bucaram as can be concluded from Carlos de la Torre's study of populism and Ecuadorian politics (De la Torre, 1998) embodied two of the most problematic and emblematic characteristics of Ecuadorian politics: patriarchal personalism and traditional populism. As De la Torre (1997:16) puts it: 
Abdala Bucaram presents himself as a new Messiah, arguing that belief in him will bring redemption. His political messianism is conveyed through a rhetoric that constructs rivals as enemies who have to be destroyed. Since he incarnates virtue and moral redemption, his enemies represent sin and misery ... He ridicules his rivals' delicate manners and tastes, which he contrasts to his own and the common peoples' masculine ones. The representation of the oligarchy as imitators of foreign and effeminate lifestyles is well received by his audiences. He not only reproduces machista prejudices but also encourages male manual workers' pride in their own virility as contrasted to the perceived lack of manliness among their superiors.

It should be noted as De la Torre (Ibid.) and others have (Pachano, 2007, 2010; Burbano de Lara, 2003) that personalism and populism have largely defined the state, government and politics in Ecuador. The stability of state institutions, or lack thereof, have largely depended in many ways on the gluing power of a charismatic leader and the power struggles between strongmen. As I will argue later, one of the peculiarities of the current process of state reproduction and statecraft is that the stability and strength of the state cannot be reduced to the charismatic leadership of Rafael Correa (even though his presence is, undoubtedly, a crucial factor in the process of state formation).

During this period, particularly between 1990 and 1999, not surprisingly, one of the main sources of opposition from within civil society came from indigenous peoples (Yashar, 1999; Zamosc, 2007). The 1990s were indeed a 
defining decade for the indigenous movement. At the height of neoliberalism, indigenous peoples organized a number of protests. There were large-scale protests every year and various small-scale ones as well (Yashar, 2005; Andolina, 2003). In addition to the 1990 protest mentioned before, in 1993 CONAIE took to the streets over the government's plan to cut social security and health services for rural areas. After important road blockades and demonstrations in urban areas the government capitulated and restored the budget for the services being cut. There were similar mobilizations in 1995, 1996 and 1997. In many of these instances, as Zamosc (2007) shows, the state and its government were forced to pull back and reconsider reforms that directly affected popular sectors.

By 1995 CONAIE and other social movements and organizations had formed the Coordinadora de Movimientos Sociales (CMS), a coalition of popular forces opposed to neoliberalism. By 1996 the indigenous movement largely represented by CONAIE in association with the CMS formed the political party "Pachakutik" and entered electoral politics with its own party. While some indigenous leaders were critical of joining the formal political system Pachakutik did enter the 1996 parliamentary and presidential elections, enjoying moderate success:

Their presidential candidate, while unable to make the run-offs, finished a strong third with just over $17 \%$ of the total votes cast (including blank and nullified ballots), candidates for the National Congress captured eight seats, and numerous victories occurred at the local and provincial levels. In all, Pachakutik candidates won a total of 76 offices (Mijeski and Beck, 2004: 50). 
In 1997, only after six months into his presidency Bucaram was deposed by a massive expression of popular discontent; he was replaced by interim president Fabian Alarcon. The political crisis prompted by the overthrow of Bucaram led, once again, to the drafting of a new constitutional arrangement in $1998 .{ }^{16}$ Traditional elites, supported by the military convened in Sangolquí, a town in the outskirts of the capital city of Quito, to draft Ecuador's nineteenth Constitution (Ayala Mora, 2010). As mentioned before, by this time the indigenous movement led by CONAIE was a major political force in the country and their involvement in the political reshuffling that preceded the Constitutional Assembly of 1998 was notable. During the Assembly CONAIE made explicit demands on Assembly members some of which were negotiated notwithstanding the continuous demonstrations of discontent carried out by the indigenous movement during the Assembly. A significant achievement for the indigenous movement at the time was the creation of CODENPE (The Council for the Development of Indigenous Peoples and Nationalities of Ecuador). CODENPE, like DINEIB, was an autonomous institution also dedicated to the promotion of development in indigenous communities; like DINEIB's, CODENPE's governance structure was representative of indigenous nationalities and peoples (Martinez-Novo, 2010). Later, in 1999, the National Health Directorate for Indigenous Peoples and Nationalities of Ecuador was created, and in the year 2000, the Fund for the Development of Indigenous Peoples of Ecuador (FODEPI) (Opsina, 2009: 132). While paradoxical in some respects, the disarticulation of state

\footnotetext{
${ }^{16}$ In reality what was drafted was a thorough constitutional reform, not a new Constitution as such (Ayala Mora, 2011: 200); however, the document produced in 1998 is generally known as the 1998 Constitution and is officially counted as Ecuador's $19^{\text {th }}$ Constitution.
} 
capacities by neoliberal reforms and the complexities of dealing with the indigenous "issue," led to the creation of an indigenous, autonomous institutional structure within the state. The institutional reforms put in place by neoliberal governments and a neoliberal-friendly constitution like the 1998 Constitution, meant that indigenous populations could exercise a modicum of self-governance and autonomy. This change further exemplifies the co-constitutive nature between state and society (cf. Migdal, 2004)

Nonetheless and notwithstanding these noteworthy developments, indigenous organizations were "appeased" by the inclusion of a watered-down version of one of their most radical demands, namely the formation of a plurinational state in Ecuador. Instead what the Assembly did was to nominally define Ecuador as a "pluricultural" state (Andolina, 2003; Jameson, 2011). Plurinationalism in contrast to "pluriculturalism" demanded a radical change, not only in the nominal definition of the state but also in actual cultural, economic and political practises of society and state. A plurinational state demanded a high degree of political autonomy for indigenous populations, beyond that provided by CODENPE or DINEIB, as well as the recognition of indigenous territories (not simply indigenous "land") within the state (see CONAIE, 2014: http://www.CONAIE.org/sobre-nosotros/que-es-la-CONAIE) and indigenous epistemic claims to new forms of living outside of capitalism (cf. Rojas, 2009).

Moreover and beyond the failure of the Assembly to take into account the radical demands for change made by CONAIE, out of the 1998 constitutional project no radical changes emerged. What the new constitutional arrangement of 1998 
sought to institutionalize was the neoliberal project started back in the 1980s and that was deepened during the early 1990s (Correa, 2010). During the course of the 1998 Constitution's rule the country witnessed the further disarticulation of the state and its relative weakening vis-à-vis the market and (traditional) economic interests. Consequently, in 1999-2000 Ecuador experienced a near complete economic collapse. One of the earlier causes of the crisis can be traced to the Ley General de Instituciones del Sistema Financiero (General Law for Financial System Institutions), enabled by eh 1998 Constitution, which largely deregulated the financial system, weakening regulations on banks (Correa, 2010). Eventually a large portion of Ecuador's major banks collapsed, leaving tens of thousands of people without their savings and thus leading to a deep socio-economic crisis in the country.

Not surprisingly the 1999 economic crisis also fuelled a further political crisis. In 2000 president Jamil Mahuad was ousted by popular demonstrations and a minor military revolt; Mahuad was replaced by Vice-President Gustavo Noboa and later by Lucio Gutierrez in 2003. Gutierrez was in turn overthrown in 2005 after a new wave of popular demonstrations (mainly Quito's middle classes) and following the armed forces' declaration that they could no longer guarantee the personal safety (from the protestors) of President Gutierrez.

Lucio Gutierrez came to prominence during the 2000 revolt against the government of Jamil Mahuad. Gutierrez led a small group of mid-range army officers in the coup d'état that toppled Mahuad. Under a leftist rhetoric, Gutierrez's group of army officers joined CONAIE in a united front against neoliberal reforms, 
dollarization and oligarchical rule. However, by the time he became President in 2003, Gutierrez quickly retracted from his leftist, popular-oriented rhetoric and signed a letter of intention with the IMF, supported the Free Trade Agreement of the Americas (FTAA) and applied IMF-supported shock-therapy measures to balance macroeconomic indicators (Hurtado, 2006). This prompted his distancing form the social base that had elected him as president, particularly the indigenous movement. As mentioned above, by 2005, only two years after he had been elected, Gutierrez was deposed by a wave of popular protests (Ayala Mora, 2010).

In sum, between the election of Bucaram and the election of Gutierrez, the Ecuadorian state had gone through several periods of politico-institutional and economic crises, which, in addition to the continuous prevalence of neoliberalism, undermined the state and its capacity to generate equitable developmental processes, rearticulate social structures in order to reflect Ecuador's cultural and epistemic diversity, to effectively regulate the market and guide the construction of a political system capable of generating stability. Alfredo Palacio replaced Gutierrez until 2006, when general elections were held and current President Rafael Correa was elected.

\subsection{Contextualizing the Election of Rafael Correa, 2006-2007}

After the 1998 Constitutional Assembly, instead of heading towards a period of political stability and the reconstitution of the state, Ecuador continued to experience important problems (the financial crisis, the overthrowing of presidents, etc.). The period between 2002 and 2006 could be defined as a period of political 
and institutional crises. The election of Lucio Gutierrez in 2002 with the support of CONAIE proved short-lived as Gutierrez was overthrown by a spontaneous coalition of the middle-classes and the military in 2005. Gutierrez was a Colonel of the army who in 2000 had sided with indigenous populations in the overthrow of President Jamil Mahuad.

Gutierrez was elected with a rhetoric that promised to re-found the Republic, redistribute resources, reform the state through principles of social justice and equity. Gutierrez's promises also proved short-lived and his presidency was characterized by the application of well-known neoliberal policies (like implementing IMF approved structural adjustment plans) and, importantly, by an open attack on CONAIE and the indigenous movement's unity. CONAIE's initial support of his candidacy, in addition to Gutierrez's attempts to undermine the indigenous movement's unity and his eventual overthrow affected CONAIE's strength - at least relative to what it had been during the 1990s. As mentioned in a previous section, the interim government of Alfredo Palacio replaced Gutierrez. Finally, in 2006 Rafael Correa, a political outsider, and Alianza Pais (AP) his political movement were elected at the expense of traditional parties.

As can be seen, an important historical dimension of the Ecuadorian state is its cycles of articulation and rearticulation. This phenomenon can be observed both in the international as well as domestic dimensions of the state. Ruptures and conflict, represented in constant constitutional changes, coups d'état, "revolutions," institutional/legal changes, economic crises and continuous reshuffling of sociopolitical forces in control of the state, have been a main theme in the state's history. 
Presidents in Ecuador, for example, are supposed to be elected for a four-year period (a normative standard that began in 1830). This means that if respected, this regulation would have produced in the 1830-2007 period, 44.25 different Presidential periods; however, Ecuador has had 88 different periods. In fact, just between 1979 and 2007, when current President Rafael Correa was elected, there were ten presidents, in other words, one president every 2.8 years. By contrast, President Correa has been in power seven years. In other words, if compared to the most recent period of democratic life, where elections matter, Correa's presidency has been unprecedented.

Also unprecedented has been the levels of state growth and presence of the state in society. One of the most important and widely recognized aspects of the Ecuadorian state has been its limited capacity and reach. This, it can be argued, is evident from various perspectives: from mainstream development narratives, it is clear that the state has had limited effects on leading developmental efforts. Poverty, instability, poor economic growth, a very poor redistribution of resources, high levels of corruption and patrimonialism indicate the state's poor performance in fostering sustained periods of development (2007, cf. 2010).

While it is important not to overemphasize institutional instability as an interpretive factor, it is worth pointing out that crises at the level of political institutions, or at least crises at the degree observed in Ecuador have effects at the level of governmental regimes, the capacity of the state to "penetrate society" and create stable/strong forms of rule. The Ecuadorian state could, up until 2008, largely be defined as a relatively weak state (Migdal 1988, 2001; Scott, 1998). As 
mentioned above, earlier in the $20^{\text {th }}$ century and certainly in the $19^{\text {th }}$ century, the state had a very limited reach and many of the relations of production, social reproduction and even normative structures were carried out by private systems through Haciendas (cf. De la Torre, 1989; Waters, 2007; Guerrero, 2010). Towards the end of the $20^{\text {th }}$ century, a different, and yet similar process further disarticulated the state: neoliberalism.

Hence, two issues largely defined the electoral rhetoric during the general elections of 2006: "Re-founding the republic" (starting the state-building project from anew) and an overt opposition to neoliberalism. Specifically, as Victor Granda (as cited in Ayala Mora, 2010: 199) points out:

Correa's electoral triumph at the end of 2006 took place in very special circumstances in Ecuador's history: the wearing out of traditional political forces; an ideological and organizational dispersion of social and alternative political forces; a growing dissatisfaction with the rentierist and speculative economic system imposed by international financial institutions in association with local economic elites and the poverty, unemployment and migration it brought about; a significant growth in the rents generated by the state because of international oil prices.

It would be useful to qualify Granda's diagnosis in at least three senses: first, in part, "traditional political forces" were political parties. Correa's campaign was largely rooted on the de-legitimation of traditional political parties. Often referring Ecuador's political system as a "partyocracy" Correa sought to link political participation and democratic politics to the notion of social movements, not parties 
(which in part explains the slogan behind AP's and Correa's project, the "Citizens' Revolution"). He argued that parties had been nothing more than corporatist organizations representing the interest of a few and not the interests of Ecuadorians at large.

Second, it is worth noting is that popular dissatisfaction was not only directed at or about "traditional political forces" but was about the political system itself. This meant a long-standing dissatisfaction with democracy in general (Ayala Mora, 2010). In this sense, the period preceding and including the convening of the 200708 Constituent Assembly was characterized by a growing interest in (and significance of) what has been termed participatory citizenship and participatory (or radical) democracy (Ellner, 2012). And finally, it is worth pointing out is that the economic system not only meant, as Granda put it, speculation and rentierism, poverty, unemployment and migration, but also high levels of inequality and the disarticulation of a state apparatus capable of undertaking the necessary structural changes that would revert the expanding socio-economic gap that neoliberalism had set in motion (cf. Evans, 1995). Thus, one of the central campaign themes during the 2006-07 presidential elections were popular participation, a restructuring of democracy, social justice, and the development of a post-neoliberal state (see Alianza Pais, 2006: http://www.scribd.com/doc/31619413/Plan-de-GobiernoAlianza-PAIS).

\subsection{The Years Leading to the 2008 Constituent Assembly and the Crisis of CONAIE $2002-2008$}


Given the discussion of the pre-2008 Constituent Assembly period provided earlier, I will briefly contextualize some of the most important historical developments in the indigenous movement leading to the election of Rafael Correa and the convening of the 2008 Constituent Assembly. Previously, it was showed that one of the main characteristics of the pre-Constituent Assembly period was the active involvement of the indigenous movement, particularly CONAIE and that this period was characterized by a highly politicized and active form of popular participation. It could be argued that this was a period of high hopes for CONAIE. Not only because then-candidate Rafael Correa and AP had adopted in their rhetoric and government plans some of the civilizational challenges promoted by CONAIE, but also because CONAIE, particularly since 2005, had experienced a period of relative decline.

It would be worth noting that, according to Pablo Ospina (2009: 124-141) there are four different explanations for CONAIE's relative decline. The first is that by entering into formal electoral politics and entering into the formal system, a gap between leadership and grass-roots membership began to form; second (and this bares an important linkage with my arguments later), in the 1990s, during the height of neoliberalism, NGOs inserted themselves as agents of "social development" in indigenous communities. Development projects within these communities "slowly transformed [indigenous] political leaders into NGO technical workers" (Ospina, 2009: 126; cf. Ferguson, 1994). Third, alliances with non-indigenous organizations hurt the indigenous movement. Particularly during the time the indigenous movement aligned itself with former President Gutierrez, internal 
fragmentations and divisions within the movement emerged. And finally (the explanation favoured by Ospina), due to limitations in their internal organizations, CONAIE never accumulated enough "social and political strength" to be able to carry out their more ambitious and radical structural changes. In other words, CONAIE's project was never successfully "mainstreamed" or transformed into electoral victories (Ospina, 2009: 129-141).

Faithful to their campaign promises, in 2007 Correa and AP called for a plebiscite to ask the electorate whether they agreed to convene a Constituent Assembly. People voted in favour of the Assembly project and in late-2007 the Assembly met for the first time in the coastal town of Montecristi. Correa and Alianza Pais obtained a majority of seats in the Assembly and from the beginning of the Constituent process the issue of participation was of particular importance. It could be argued, as I do later, that the first stage of the constitution of the "new" state was its most participatory and was the period immediately preceding and during the Constituent Assembly. I should say, nonetheless, that as Ayala Mora (2010) has pointed out, the vast majority of articles of the 2008 Constitution were derived from within the government and particularly from within Correa's closest circle.

Notwithstanding the difficult question of how much participation there actually was during the Constituent process, it is clear that in the period preceding and during the Constituent Assembly, there was, relatively speaking, more room for a politicized sense of participation, in the sense of not only of preserving the active mobilization of social forces through organized civil society (NGOs, indigenous 
organizations, popular organizations) as well as maintaining the "radical ethos" of the first period of the Correista state. According to Alberto Acosta (2008), for example, over three thousand petitions, suggestions, and demands from organized groups from civil society were taken into consideration during the Assembly. I interviewed a founding member of AP and high-ranking government official during the first year of Correa's government and she confirmed the view that between 2007 and 2008, there was a real sense of political participation from within AP and between AP and civil society. Specifically she mentioned that participation was never stripped of its radical ethos, it was essentially a political act (Anonymous Interview, Quito, June 14th 2012) linked to the radical restructuring of the state, society, the economy and the political apparatus. During this first period of the rearticulation of the state, for instance, indigenous organizations like CONAIE who had experienced tensions with the government from the beginning of the constituent process, along with other indigenous organizations secured six articles $1100 \%$ of their proposals) in the new constitution: "recognition of the plurinational character of the Ecuadorian state; interculturalism; land and territory of the Indigenous peoples; the proclamation of Kichwa as official language of Ecuador (accepted as an official language of intercultural relations); Indigenous justice; and environmental rights" (Agrawal et al. 2011: 9).

The high levels of politicization in the first period of the Correa's government are evident relative to the second and third periods of the Correista state. One could argue that the calling and convening of the Constituent Assembly itself was a quintessential political act and not necessarily because of its implications for the 
formal re-organization of the state, but primarily because of its radical content (see Chapter Five) and because its convocation emerged as a demand of organized popular movements and was expressed through popular mobilizations as well as elections. As Marc Becker (2011: 49) notes,

On April 15, 2007, over 80 percent of the Ecuadorian electorate approved a referendum to convoke a constituent assembly. In no small part, the success of the referendum was due to the support of indigenous communities. 'It is a victory for the indigenous movement," Humberto Cholango (2007a: 3), president of Ecuarunari, declared, "the triumph of all of the accumulated histories of the indigenous and popular social struggles in Ecuador.'

Similarly, as Alberto Acosta, first president of the 2007-2008 Constituent Assembly put it, the rationale behind the drafting of a new Constitutional text was to "recuperate the capacities of and action by the people as protagonists of their own history and life project, it is indispensable do away with neoliberal constitutionalism, revaluing popular sovereignty, democratizing society (sic)" (Acosta, 2008: 15).

The months prior to and during the Constituent Assembly were characterized by a relatively high degree of popular activism seeking to directly participate in the act of government (by influencing the content of Constitutional articles). Once convened, the Assembly structured its work through thematic tables in coordination with members from organized popular groups and civil society organizations. The Carter Center (2008: 6) described the socio-political climate at the time in the 
following way:

From the first day of the Assembly's session, diverse social organizations, representing rural, human rights, ecological and other interests, camped out in the vicinity of the Assembly to make a permanent observation of its work ... At the same time some civil society organizations met with Assembly members to present them their specific proposals for the new Constitution.

Moreover, according to the Assembly's press releases at the time, between lateOctober 2007 and mid-January, 2008, the Assembly had received the demands, petitions, ideas and/or plans of five hundred civil society organizations and about six thousand individuals (Ortiz Lemos, 2012: 62). While there are clear signs that most of the final articles in the 2008 Constitution were reached through little and/or poor deliberation and emerged from within Correa's political movement, particularly its elites (Ayala Mora, 2010), it is also clear that the Constituent Assembly and the state more generally, were at this time relatively open to the influence of radical politics from popular forces. As Ayala Mora points out, "many of the more fundamentalist constitutional dispositions were approved as result of pressure exerted by marginal groups, despite the government's theses [on those issues]" (Ayala Mora, 2010: 202). This is perhaps most evident in the experience of the indigenous movement.

It must be remembered first, that an important portion of the indigenous movement represented by CONAIE gave its partial support to the newly formed government, particularly after Rafael Correa, upon taking office on January $15^{\text {th }}$, 
2007, convoked a popular referendum to convene a Constituent Assembly. CONAIE's main for the Constituent Assembly was to declare Ecuador a plurinational state and support this declaration with additional articles granting autonomy (territorial, educational, political, juridical) to indigenous "nationalities." Plurinationalism could be considered a radical demand in that it demanded a thorough transformation of the political, social, economic and cultural, as well as the epistemic structures that sustained the status quo in Ecuador. Plurinationalism, as mentioned earlier entails the recognition of multiple nations with their own territory, language, history, culture, and forms of organization and thinking, within one state.

A similar situation took place with the conferral of Kichwa official-language status. Despite important opposition from President Correa who thought, in the context of the deliberations in the Assembly on this issue, that "in much of the country learning English was more important than learning Kichwa," (as cited in Becker, 2011: 56) the Assembly largely adhered to the proposal made by CONAIE in this respect. The draft proposal given by CONAIE to the Assembly read: "Spanish and Kichwa are the official languages for intercultural relations. The other languages of the [indigenous] nationalities are official in the regions and areas of their use and comprise part of the national culture" (CONAIE, as cited in Becker, 2011: 56). By comparison, Article 2 of the 2008 Constitution reads:

Spanish is the official language of Ecuador; Spanish, Kichwa, and Shuar [second most spoken indigenous language] are official languages for intercultural relationships. Other ancestral languages are for official use 
for indigenous peoples in the areas they inhabit and on the terms that the law stipulates. The State will respect and will stimulate their conservation and use (Constitution of Ecuador, Article 2, as translated in Becker, 2011: 56).

Thus far, in this section I have suggested that the first stage of state-formation under Correismo was characterized by the presence (albeit limited) of contentious and radical politics (cf. Rancière, 1998; cf. Laclau, 2006;cf. Tarrow and Tilly, 2007). The first stage of state formation is different from the other stages of state formation analyzed later in this work, precisely by this point. The relationship between the Assembly and certain sectors of civil society was permeated in many cases by a revolutionary ethos that was, in part, enabled by the fact that the radical content of some of the demands, ideas and criticisms emerging form non-state actors were allowed to be included in the constitution without the government feeling obliged to later turn them into actual governmental regimes (see Chapter Four); the relatively open-ended nature of the constitutional text allowed for it. At the end of the constitutional project the 2008 Constitution was approved with 444 articles with themes including the usual characterization of a liberal state and its institutional apparatus (e.g. division of powers, branches of government), to issues related to Sumak Kawsay/Buen Vivir particularly the development of participatory democracy.

A second aspect that allowed the first stages of state formation to be permeated by radical politics was the presence and influence of organic intellectuals (cf. Cox, 1983) who later either withdrew their support for the Correista state project or were expelled from it by the government. More specifically, I am referring 
to cadres within AP who supported and gave content to Buen Vivir/Sumak Kawsaybased Constitutional Articles. Some of these individuals were Alberto Acosta, Gustavo Larrea and Monica Chuji. Alberto Acosta, in particular, played a very important role during the first stages of the Correista state. Acosta is a left-leaning intellectual who has written extensively about Buen Vivir (see for example, Acosta, $2009,2010,2012)$ and at the time of Correa's election was a professor of critical economics at FLACSO-Ecuador, one of Ecuador's most reputable graduate universities. Acosta also led the AP ballot in the elections for Constituent Assembly members and became its first president. It was Acosta, for example, who during the Assembly pushed for the full inclusion of Kichwa as an official language, giving nature rights and promoting the notion of direct/participatory democracy (Paredes, 2008; Becker, 2011). Acosta was instrumental in constructing a discursive critical mass, so to speak, around the notion of Sumak Kawsay/ Buen Vivir during the constituent period. As Pablo Andrade notes, Assembly members were constantly exposed, between December 2007 and May 2008, to a series of conferences organized by Alberto Acosta and other Assembly members, regarding participatory and direct democracy given by well-known radical-democracy intellectuals like Francois Houtart and Boaventura de Sousa Santos (Andrade, 2012: 43).

In July of 2008 the Constituent Assembly, less than a year after of convening, approved the new constitutional text with 96 votes in favour out of 130 possible votes. Later that year President Correa called for a referendum to approve the new Constitution. The referendum took place on September 28, 2008 and the new Constitution was approved with $63 \%$ of the popular vote. The new Constitution, 
Ecuador's twentieth, entered into effect in October $20^{\text {th }}, 2008$. It is important, before finishing this section, to note that the new constitution was not only the beginning of a new regulatory framework for state-society relations, it was, in a sense, the beginning of a new state project that demanded a near complete rearticulation of state practices and state-society relations. In addition to the radical articles included in the 2008 Constitution mentioned earlier, there was also an important emphasis on the role of the state and in particular of its central government, the Executive branch (Constitution of Ecuador, 2008) as an actor capable of fostering deep, radical changes in Ecuador's social, cultural, political and economic structures. From a strategic point of view, the new Constitution conferred a special status to the Executive Branch in the construction of the new state while opening up important spaces for what is referred to as direct or participatory democracy (Constitution of Ecuador, 2008: Article 93)

Thus, and beyond the Constitutional enunciations, the "new" state had to reshape itself and re-articulate the way it intervened in society. In other words, new governmental regimes had to be deployed and cemented in order to develop a stronger state. As mentioned earlier in this chapter, since the approval of the 2008 Constitution, the Correista state project has, in fact, become an unprecedented phenomenon in Ecuadorian history. Hence, the question becomes, what type(s) of state(s) is the Correista state? How did it articulate itself vis-a-vis society, particularly, in view of the participatory ideals of the new Constitution and in face of politicized minorities like the indigenous movement? How did it convert the participatory ideals of the constitutional to governmental practices? What 
characterizes the process of state construction from the point of view of governmental regimes and state power? In the following chapters I will attempt to provide answers to these questions, taking into consideration the historical context I have just laid out in this chapter and the theoretical discussion presented earlier.

Before doing so, however, I look more closely and from a historical perspective at state-society relations, particularly, some of the historical contexts that have come to define the relations between the state and indigenous peoples.

\section{Conclusion}

In this section I have attempted to emphasize indigenous agency and the importance of direct, politicized participation in state reforms. I have mentioned the colonialist practices of the state and non-indigenous society to a lesser degree in order to avoid victimizing indigenous populations and also because it is a well established historical fact that the Ecuadorian state and many of its social structures can be characterized by their historical marginalization of indigenous populations, cosmovisions and practices (see among others, Ayala Mora, 1991; Adoum, 1998; Walsh, 2007, 2010; Shciwy, 2010; Jameson, 2010; Alvarez, 2011; Macas, 2010, 2011; Ospina, 2010) . This includes, as mentioned in the first section of this Chapter, the development of a nation-building project, mestizaje, which has historically favoured the whitening of the national culture (cf. Echeverria, 2010).

In the first section of the chapter I considered historical processes of state formation, which included in some senses looking at the prevalence of colonialist social, political and economic structures within the state. Mainly, I looked at the 
unfolding of the state and its historical processes of articulation and rearticulation. I highlighted the limited degree with which strong governmental regimes developed. Thus, I characterized the Ecuadorian state, if not as a weak state, as a limited state (i.e. a state's presence as a governmental entity was relatively limited). I also stressed the importance of understanding the state, from a historical perspective, as a series of diverse projects that include diverse manifestations. More specifically I argued that historically one could observe the sequence of many state forms in Ecuador. Finally, I showed that some of the most important vicissitudes in the process of state consolidation have been political instability, institutional crises and the constant reformulation of the political structures of the state. 


\section{CHAPTER FOUR}

\section{THE NARRATIVES OF STATE FORMATION 2008-2012}

\subsection{Introduction}

Since the first years of the 2008 post-Constitutional state project the Correista state has been defined in contrast to neoliberalism. This has meant looking at the state as a force capable of redistributing resources and toning down the excesses of the market. Thus, the 2008 Constitution emphasizes the importance of reinvigorating the state apparatus and the role of the state in development. The Correista state is defined in opposition to the neoliberal state, which it views as pernicious for income distribution, social reproductive bases, the provision of basic public services, among others. But correcting the excesses of neoliberalism is not as obvious as it may appear. A more equal distribution of income, a more equitable social base and the improvement in the provision of social services could be developed, in theory, through a variety of state forms. Moreover, the Ecuadorian state has arguably been a relatively weak state. Externally this can be seen in its relative weakness in protecting its external integrity and diminishing its external dependency on northern economies. Internally this can be seen in its limited capacity to penetrate society for developmental purposes; its ability to generate equitable social processes; its limited success in fostering economic development and political stability.

By contrast, the Correista state has been relatively more successful on most of these fronts than all of its previous regimes in Ecuador. The question, of course, is how has this come about? In the following chapters I continue answering this 
question by analyzing the state as a composite of governmental regimes of practices, discourses and modalities of power. From the theoretical and methodological perspectives of this work it is futile to speak of (and study) the state as a homogenous unity that acts coherently, harmoniously and with a common purpose on all of its fronts. Similarly, looking at the power of the state as purely derived from its juridical forms or economy limits the range and capacity of our understanding of a state's capacity to act and not to act vis-à-vis other actors in a specific historical context. The construction of a new (stronger) state form, thus, will be looked at from the perspective of different regimes of government, through a governmentality approach (especially see Walters and Haahr, 2005), complemented by aspects of Weberian analytical tools and guided by the working definition of the state provided by Migdal (2001) discussed in Chapter Two.

Among the important strategies in the development of the contemporary state has been the implementation of a process of citizens' participation in different governing activities, including the most important planning guide of the state, the National Plan for Good Living (Plan Nacional del Buen Vivir - PNBV). Thus, to tackle the question of how a state is constructed, transformed and reproduced, this dissertation analyses the state through its relationship with social actors and follows the construction of the state through the involvement of citizens in government and also through the opening of spaces of government by the state. In this dissertation I understand the state as an effect, as a relation of power in itself, not as a formalistic and already-given fact. 
Methodologically, this entails analyzing the different narratives and practices deployed by the state to construct the fabric of government. This dissertation analyses how power is exercised over and through individuals and groups in participatory engagements with the state and the processes deployed by the government to make up citizens that fit with the project of society envisioned by Correa's government. This view regards the state as a strategically privileged site whose power is relationally linked to the subjects with whom it interacts. This denies, thus, a false dichotomy between a state-project either from the bottom-up or from the top-down. I am trying to emphasize the political nature of state-society relations and the "fact" that state-construction strategies ought not to be interpreted in absolute terms as accomplishments, but as ongoing projects always susceptible to challenges and opposition.

Following Migdal's conceptualization of the state mentioned in Chapter Two, in this chapter I identify the most important narratives guiding state construction since the enactment of the 2008 Constitution and the practices of government associated with these narratives, with particular emphasis on the laws of participation. Second, I present a detailed account of the most important steps taken by the state to construct spaces of government through what it calls "participatory citizenship." In particular, I present the main narratives guiding the state reform since 2008 and those present in the 2009-2013 Plan Nacional del Buen Vivir (PNBV) and the different modalities of power associated with these narratives to construct governmental regimes, its techniques, forms of knowledge and ways in which it constructs government. In this chapter I argue that the construction of the 
contemporary Ecuadorian state is dominated by two main and often contradictory narratives, one is neodevelopmentalist-modernizing and the other is inspired by the indigenous principle of Sumak Kawsay/Buen Vivir (SK/BV).

I document how the post-2008 state is caught between two main "identities": a technocratic ethos directly linked to its modernizing-neodevelopmentalist character and one associated with the principles of SK/BV. In this sense I argue that the post-2008 state cannot be reduced, as some authors do (see de la Torre, 2009, 2011) to a populist form. The power of the state is not only rooted on notions of popularity (cf. Hurtado, 1999) or charismatic leadership. As I will show with the case of the PNBV there is a complex apparatus of knowledge creation and distribution as well as a modernizing thrust within the state apparatus itself that turn the post-2007 state into a largely technocratic state - a dimension which was not present in the "purely" populist states of say Abdala Bucaram (presidential period 1996-1997) or José María Velasco Ibarra (presidential periods: 1933-1935, 1944-1947, 1952-1956, 1960-1961, 1968-1972). Moreover, the incorporation, at least initially of certain SK/BV principles played an important role as a balancing narrative in which principles of inclusiveness and the recuperation of social reproductive capacities of the state were vindicated.

\section{THE NARRATIVES OF STATE FORMATION: CREATING AN IMAGE OF THE STATE}

\subsection{On the Conflicting Narratives and Practices of Statecraft}

The analysis of discourses and narratives is also an analysis of practices, or, more specifically, of how narratives are translated into practices. Narratives are 
spoken (or written) pointers of the direction of meaning and interpretative structures through language. Narratives are spoken (or written) structures of meaning but they are not necessarily, like discourse is, linked to regimes of practices. Narratives are nonetheless, important indicators of which things are prioritized and why. This section analyzes some of the narratives defining processes of state formation since 2007. My analysis is about the representations of the state, about what it ought to be and how practices and narratives come together in a discursive field. It must be remembered that the shape of the state required a new set of narratives and practices to replace those embraced by the neoliberal state.

Narratives like discourses are essential components of state formation. As Lemke (2007: 2) puts it:

Government defines a discursive field in which exercising power is 'rationalized.' Ways in which this occurs include the delineation of concepts, the specification of objects and borders, and the provision of arguments and justifications. In this manner, government makes it possible to address a problem and offers certain strategies for managing or solving the problem.

Thus, to begin to understand how the Ecuadorian state developed since 2007, one must first look at some of the constitutive narratives and discourses that make its exercise of power possible. I nonetheless, unlike some Foucauldian scholars (e.g. Lemke, 2007) regard the unity of narratives and discourse-practice as fragile. In fact, as I show below the Ecuadorian state since 2007 is characterized by contrasting 
narratives of state formation that allowed the state to exercise power in diverse ways in the fields of participatory planning and participatory citizenship.

\subsection{State Narratives in the Process of State Formation: Sumak Kawsay/Buen Vivir and the Civilizational Challenge to Development}

The origins of Sumak Kawsay/Buen Vivir and the "civilizational" challenge it proposes can be linked to various sources not all of them indigenous. Some of them can be linked to postcolonial studies and its challenges to paradigmatic ideas about Western understandings of development (see for instance Bhabha 1995, Chakrabarty 1995, Spivak 1995). But it also responds to the work of indigenous and non-indigenous intellectuals in the Andes that work at synthesizing the cosmovisions of indigenous populations in the Andes (see for example, Flores, 2012; de la Cadena, 2010; Quijano, 2003; Macas, 2010, 2011; Stavenhagen, 1996). Earlier manifestations of some of the concepts of Sumak Kawsay/Buen Vivir in Ecuador can be traced, at the level of popular political discourse, to the emergence of CONAIE as largely an identity-based organization in the mid-1980s. ${ }^{17}$ With the emergence of CONAIE indigenous political identities, forms of organization, alternative views on development rooted in indigenous tradition slowly entered the arena of popular political discourse.

In 2006 Rafael Correa and his political movement were elected on the basis of a "foundationalist"18 discourse and the proposal of a Constituent Assembly. The

\footnotetext{
${ }^{17}$ Before CONAIE indigenous peoples in Ecuador had organized largely on the basis of class. Thus, important organizations like the Ecuadorian Federation of Indians (FEI) was largely a peasant organization.

${ }^{18}$ What I mean by "foundationalist" is Correa's proposal to restructure the very foundations of the Ecuadorian nationstate. This project was spearheaded by the enactment of a new Constitution.
} 
Correista Constitution of 2008, rejected some of the liberal principles enshrined in the 1998 Constitution (Andrade, 2007, 2012) and opened the door to the inclusion of some of the demands and ideas of indigenous peoples, certain social organizations (particularly environmentalist) and middle-class progressive intellectuals (see for example Leon, 2008, 2010; Larrea, 2008) in the form of Sumak Kawsay in Kichua or "Buen Vivir." As shown below, SK/BV encompasses a series of positions and demands that are in many instances defined precisely by their foundational challenges to paradigmatic understandings of development.

Indeed, SK/BV as a "political philosophy" could be defined as an alternative to what Roberto Espinoza (2010: 1) refers to as a hegemonic civilizational crisis of Eurocentric developmental discourse-practices and what Cristina Rojas, following Gibson, calls capitalocentric economic forms of development (cf. Rojas, 2009). The crisis of which Espinoza speaks is a crisis engendered by modernity itself (cf. Echeverria, 2010); a crisis directly linked to the epistemic regimes rooted in Eurocentric ways of knowing (Quijano, 2004) and defining people's relation to their environments. $S K$ in this sense entails an opposition to capitalist, racist and gendered hierarchical regimes of progress that benefit whites and males. Moreover, SK embraces a type of ontological dialogism (Escobar, 2010) that regards humans, not at the centre of life (i.e. humanism), but as part of an organic whole - a whole that conceives the environment as a living being (Chancosa, 2010; Schiwy, 2009; De la Cadena, 2010; Alvarez, 2011).

Since enacting Ecuador's latest Constitution in 2008 there have been two contending narratives about progress and state formation. In what follows I would 
like to contrast and show the tensions that exist between these two contending narratives of progress and State formation and later show how these coalesce in practices of participatory government. Moreover, I will show the ways in which these two narratives interact and relate to power modalities like governmental/pastoral power and disciplinary power in the construction of governmental regimes.

As a political "doctrine" $S K / B V$ can be if not defined in specific terms, associated with a few important concepts. The first is plurinationality. This concept can be broadly defined in terms of indigenous peoples' political and cultural autonomy as nations, but under the jurisdiction of one state (CONAIE, 2013). A related concept is that of interculturality. Interculturality is often defined as the coexistence of diversity in an environment of political, cultural, economic, political and epistemic diversity (Walsh, 2009). This concept departs from the idea of multiculturalism in that the very political and economic structures of the state are affected and defined in radical terms through intercultural exchanges (cf. Kymlika, 2007; Walsh, 2009).

Forms of political organization linked to $S K$ are direct, radical and communitarian forms of democracy in which the community-based systems of decision making of indigenous populations serve as examples (Larrea, 2011). In consequence, the Constitution also defines Ecuador's democracy as participatory and direct (Constitution of Ecuador, 2008: Articles 1,95) and calls for direct political participation in the form of an actively politicized civil society and mechanisms like previous consultation and previous consent (Becker, 2010). The main body of the 
Constitution mentions the term participation 80 times, making participation one of the central themes. The participatory ethos of the new Constitution calls for a strongly politicized and organized society. As Alberto Acosta, former President of the Constituent Assembly noted in reference to the 2008 Constitution: its fundamental objective is "the re-politicization of Ecuadorian society, reflected in a growing consciousness on the part of the majority about the need for and, above all, the possibility of change." (Acosta, 2009: 55). In other words, a central aspect of $\mathrm{SK} / \mathrm{BV}$ is to (re)politicize social forces. Not unlike participation at the dawn of the new social movements in Europe (cf. Mose, 1999), Sumak Kawsay/Buen Vivir regards participation as a fundamentally political exercise: not a technocratic process associated with policy making or a procedural one related to electoral campaigns and voting, but instead, a non-violent encounter between opposing forces, including narratives, actors and institutions - an exercise which depends on the active participation of popular organizations.

On the economic side, one could argue that $S K$ entails the notion of an economic system rooted in solidarity, limited growth and a post-extractivist ${ }^{19}$ economic system. Solidarity in the Constitution is often equated to equality and a more equal distribution of income (see for instance, Constitution of Ecuador, 2008: Article 85); food sovereignty (Ibid.: Article 281); popular and community-based economic systems (Ibid.: Article 283) and sustainability (Ibid.: Article 284). According to Alberto Acosta (2011) this all relates to what could be termed the

\footnotetext{
${ }^{19}$ At a basic level "extractivism" can be defined as the state's financing of its developmental model through the intensive extraction/exploitation of natural resources. This presupposes that a considerable portion of its income is derived from petroleum exports. Indeed, petroleum is the single most important export (in terms of dollar value) that Ecuador has (Ministerio de Economía del Ecuador, 2013).
} 
economy of Buen Vivir and has the ultimate objective of correcting the evils of modern capitalism, by respecting nature and putting human life at the center of economic considerations.

Civilizational changes proposed by $S K$ demand radical transformations in the social, political, economic and cultural structures of the country, but in Ecuador a part of the state has embraced the ideals of SK. Perhaps the two most emblematic examples of this are the 2008 Constitution and the Planes Nacionales del Buen Vivir (PNBV:2007-2009, 2010-2013, 2013-2017). In its Preamble, the Constitution of Ecuador makes references to a dialogic relationship between humans and nature; it also alludes to millenary peoples (indigenous peoples); cultural diversity and the inheritance of the peoples of Ecuador of the anticolonialist struggles of the past; it also states Ecuador's objective to reach SK (Constitution of Ecuador, 2008: Preamble). In fact, the notion of SK influences, as Magdalena Leon notes, all the 444 Articles of the Constitution and is specifically evoked no less than twenty times (Leon, 2008: 1). Beyond the Preamble, the Constitution defines Ecuador as an intercultural and plurinational state (Constitution of Ecuador, 2008: Article 1).

Nonetheless, I should point out that SK is not a uniform "doctrine," nor are its conceptual and practical parameters agreed upon by indigenous organizations, social movements or progressive NGOs. Indigenous organizations like FENOCIN (see for example, FENOCIN, 2013), for instance more strongly accentuate the relations of production side of a new politico-economic doctrine while CONAIE emphasizes the more abstract notions linked to identity and indigenous cosmovisions (see CONAIE, 2013). Many of these aspects are still being debated and 
are not clearly understood in practical terms. Take for instance the question of plurinationality, the rights of nature or a post-capitalist (or anti-capitalist) economy. In this respect the debate about the specific parameters of SK are open. This openness serves a strategic purpose as it allows the state to employ the term in a multiplicity of ways but continuously evoke the "foundationalist" and radical meanings of the term.

Image 1 presents a billboard in the capital city of Quito that employs the term. One of the aspects worth highlighting about Image 1 is that it stands in one of the most affluent and modern parts of the city and refers to an urban modernization project involving the improvement of sidewalks and the placement of wires underground - mainly an aesthetic project. The billboard illustrates how the narrative of SK or Buen Vivir is employed beyond the foundationalist or radical (i.e. civilizational challenges) meanings with which indigenous peoples, social movements, or progressive intellectuals may associate the term.

In sum, state narratives are permeated by references to SK's language, particularly its Spanish translation "Buen Vivir." It is clear, as shown above, that the references to Buen Vivir play an important role in defining the character of the state at the level of its narrative base.

\subsection{Modernizing Neo-Developmentalism}

Before discussing aspects of what can be considered modernizingdevelopmentalism, it would be useful to draw from Patrick Thaddeus Jackson's reading of Weber (Jackson, 2008) to make one initial point clear: the ideal figure of 
the modernizing-developmental state. In this chapter I lay the foundation for what in later chapters I refer to as the "regime of improvement" of the state (cf. Li, 2007a). In short, the regime of improvement is the government's preferred paradigm of development. The notion of improvement comes from Foucauldian analytics to refer to the relationship between subjects and improvement and from governmentality studies where "government" is in many ways understood as a preoccupation with improving the conditions of populations. But clearly, improvement can acquire many forms, according to various elements, such as the prevalence of certain hegemonic discourses, historical epochs, availability of resources, etc. However, before identifying what in this dissertation I understand by "improvement" (in the case of Ecuador I argue that improvement is associated with modernizingneodevelopmentalism), it would be useful to stress that, and here is where I follow Jackson (and Weber), that "modernizing-developmentalism" is not the "essence" of the state but an ideal-type. The Ecuadorian state is not a homogenous entity characterized by a developmentalist, empirically verifiable, formula guiding all of its actions. Rather, as Weber (cited in Jackson, 2008: 147) puts it, ideal-types are:

formed through a one-sided accentuation of one or more points of view and through bringing together a great many diffuse and discrete, more or less present and occasionally absent concrete individual events, which are arranged according to these emphatically one-sided points of view in order to construct a unified analytical construct [Gedanken]. In its conceptual purity, this analytical construct [Gedankenbild] is found nowhere in empirical reality; it is a utopia. 
Image 1: Buen Vivir Billboard in Quito. "We Work for Quito of Good Living." Project for recuperating sidewalks and placing city cables underground, Quito, Ecuador.

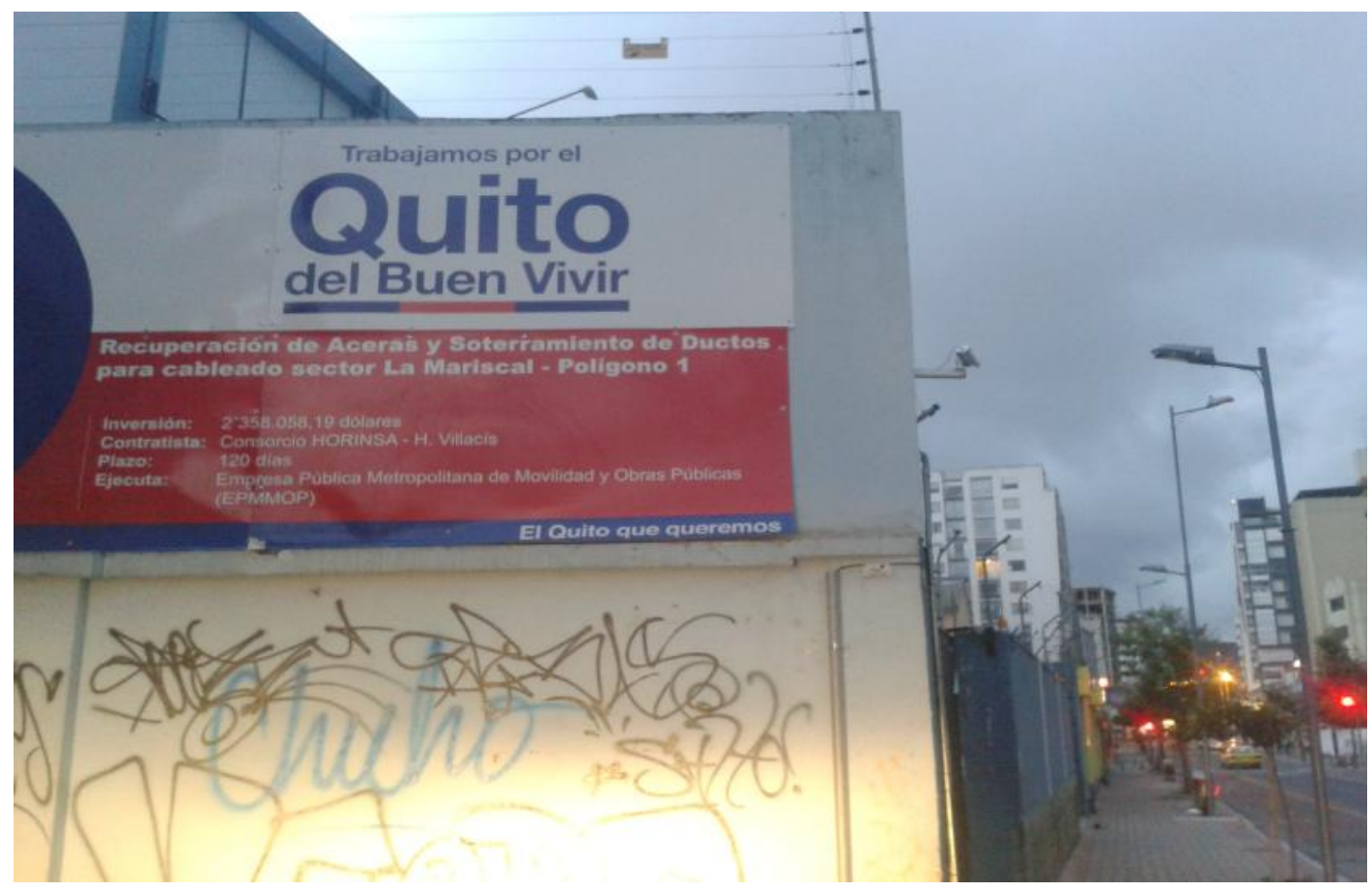

Source: Picture taken by the author, Quito, March 2014.

Moreover, Jackson (Ibid.) notes, "[i]t should go without saying that ideal-types cannot be evaluated based on their accuracy or their correspondence with any set of empirical facts; rather, ideal-types form the horizon within which 'the facts' arise." In this sense, even though I analyze some of the theoretical trademarks of developmental states and compare them with certain state practices, I do not claim that those are the essential features of the state. Instead I look at how modernizingdevelopmentalism constitutes an essential element in the construction of the state as image and practice without ever assigning to the concept a reifying relationship with the state. 
Traditionally, developmentalism and the developmental state has been associated with the promotion of industry, typically through the implementation of import substitution, the maintenance of high employment, and emphasis on largescale productive infrastructure projects and a well-developed bureaucratic, meritocratic apparatus as well as developing a middle-class (Cardoso and Faletto, 1979; Johnson, 1982; Woo-Cummings, 1999; Ross Schneider, 1999). There are different characteristics among developmental states but at the core of the definition lays the notion of the state as an active and salient agent of economic and social "development." Thus, my characterization of the Ecuadorian state is not necessarily identical to that of other developmental states, particularly because of the absence of an active large-scale, state-led industrialization project.

The concept of the "developmental state" was originally defined by Chalmers Johnson (1982) to describe the experience of post-war states that did not fit either the Stalinist or the liberal-capitalist states of North America. Mainly based on his research about the MITI in Japan, Johnson argued that the developmental State was different from the free-market liberal and Soviet state forms. It was characterized by its active intervention in the economy, its commitment to industrialization, the restructuring of the productive base and the development of a modern meritocratic bureaucracy (Johnson, 1982). In Latin America the concept is directly associated with the so-called structuralism derived from the work of the Economic Commission for Latin America and the Caribbean (ECLAC) (Morais and Saad-Filho, 2012; Love, 2007). Structuralism and neo-developmentalism is summarized in the following synthesis, 
(1) Strong markets can exist only with a strong state; (2) Sustainable growth is impossible ... without strengthening ... the state and the market, and without the implementation of adequate macroeconomic policies; (3) strong markets and states can be built only through a national development project which makes growth compatible ... with equity; and (4) it is impossible [to reduce] inequality without rapid and sustained growth. (Sicsú et al., as cited in Morais and Saad-Filho, 2012: 791).

From a more political-organizational standpoint, one of the important aspects of a developmentalist state, and what could be called developmentalism more generally, are its parallels to the modernization discourse about the state. Particularly, the notion of moving from a sense of perceived chaos to "some implicitly understood order" (Migdal, 2009; cf. Lerner, 1958). This process of order seeking can be equated at the level of state reform to what Weberian scholarship calls "rationalization" of the state apparatus (Evans, 1995). Weberian scholarship argues that the process of modernization of a state and its process of rationalization are often concurrent. An application of Weberian scholarship to the study of the state is Peter Evans' (1995) embedded autonomy argument. Evans' analysis, as pointed out in Chapter Two, regards the most progress-inducing state form as an embedded autonomous state whose main characteristics include the development of a legal-rational bureaucratic apparatus.

The implications here are that a modern, rational bureaucracy, which is the opposite of traditional and personal-charismatic leadership forms, is more directly associated with progress and development. And even though Weber argued in 
favour of multiple forms of rationality and types of political legitimacy, the undisclosed implication of the legal-rational-bureaucratic line of argumentation is that the optimal form of rationality for state developmental purposes is a modernizing-bureaucratic, Western one (Cummings, 1999). As far as state development goes, certain Weberian-influenced approaches set a standard; a standard, that, like I said, places modernization at the centre of state development and progress.

\subsection{Defining the State as Image: Narratives about Development, Progress and Sumak Kawsay/Buen Vivir}

At this point I would like to show the ways in which, beyond the formal structures of the state, modernizing-developmentalism and $S K$ narratives meet, particularly in the formation of governmental regimes. Moreover, I show that the tension between these two narratives in practice favours modernizingdevelopmentalism. Nonetheless, later in the chapter I show how and why the presence of these two narratives is important for the exercise of government and state development since 2007. I argue that in the case of Ecuador since 2008, the construction of a modernizing-developmentalist state and its corresponding governmental regimes are rooted in a depoliticizing strategic thrust which fundamentally contradicts the tenets of SK regarding, as Acosta (2008) put it, the repoliticization of Ecuadorian society.

The developmentalist narrative entails first, embracing a legal-rationalistic conception of bureaucratic development and second, that the epistemological and empirical references for rational, progress-conducive policy choices can be located 
in Eurocentric sources of enunciation. I should stress, however, that unlike traditional East Asian developmentalism, Ecuador's developmentalism is not limited to industrialization and industrial policy development. It has also been influenced by the type of developmental ethos aptly defined by Arturo Escobar in "The Invention of the Third World" which is fundamentally concerned with lifting Third World states out of "underdevelopment." James Ferguson has aptly described practices based on this ethos in the Anti-Politics Machine (Ferguson, 1994). Specifically, Ferguson associated the expert-knowledge effects of the aid-industry to a depoliticizing tendency in development projects: the government of development Ferguson argued, acts as an anti-politics machine. As I will show through a case study of participation and the PNBV in a later chapter, this is a characteristic of the way in which participation is governed.

\subsection{Modernizing-Neodevelopmentalism and the "Efficient" State}

The evidence presented comes from a content analysis of twenty three-hour Weekly Presidential Reports (WPR) reports between 2009 and 201220; interviews with state officials, government documents as well as state-management strategies, techniques and, thus, practices. In the process of research of state behaviour I found ample evidence suggesting that modernizing-neodevelopmentalism is a strong narrative within the state, particularly in the speeches and weekly reports of the president of the republic. Because of the characteristics of the leadership structure

\footnotetext{
${ }^{20}$ WPRs began in 2007 . The selection was made in order to have a representative sample of each year for all the years covered in this study (and for which data is available), considering the temporal focus of this dissertation's research. I paid particular attention to WPRs dealing with state-society confrontations, particularly with indigenous populations.
} 
in the Ecuadorian state (a presidentialist system in the Republican sense) one cannot be unaware of the importance of the President as a source of narrative structures; hence the choice of an in-depth analysis of Correa's weekly reports.

Upon conducting a content analysis of Correa's weekly reports one of the first narratives to emerge is that of an efficient highly technical state. According to President Correa, his government is characterized by possessing the highest "technical level" (i.e. academic training levels of governmental officials) in Ecuador's history and currently in all of Latin America (WPR, 2012: \#286.). This means that rearticulating the state is not only about enlarging it (thus departing from the neoliberal ideal of a minimal state) but making it more "efficient," more "technical." One of the important findings in the content analysis I undertook is that there is a clear conceptual linkage between modernization, efficiency and state reform; a narrative akin to a Weberian sense of development. While the analysis I conducted cannot, in any conclusive terms, define what efficiency means in all instances, it could be said that "efficiency," according to the Presidency, has some of the following characteristics: a young, professional, well-educated (Master's or $\mathrm{PhD}$ holders) and meritocratic roster of bureaucrats (Weekly Report, 2012: \#295); high productivity (WPR, 2012: \#275) and a rationalized bureaucratic system (e.g. WPR, 2012: \#295; WPR, 2013: \#321).

If one compares this notion of an efficient state to that of Peter Evans' Weberian-inspired embedded-autonomous state, one finds a number of striking similarities. According to Evans an autonomous-embedded state has some of the following characteristics: a meritocratic system of selection of bureaucrats; highly 
educated roster of technocrats and a highly professionalized and organized bureaucracy. One of the central conceptual relations in this narrative is, as mentioned above, an association between neodevelopmentalism, progress and progress/improvement and a legal-rational bureaucratic form of state. According to Evans the archetypal Weberian state is a developmental state (also referred to as a developmental state by Evans), the South Korean state. In a humorous yet revealing phrase, Correa often refers to Ecuador and its developmental paradigm, in analogous fashion to the Asian "tigers," as Latin America's "jaguar" (see for instance, Weekly Report, 2013: \#319). While not as common as the references to Western European and North American countries, deferential allusions to East-Asian developmentalist states and developmental paradigms are apparent (see, for example, Weekly Report, \#286). The idea of the East-Asian developmental state clearly appears in governmental narratives about the state and its merits and the direction of societal development.

\subsection{The Neo-Developmental State in Practice: Structural Reforms and Extractivism}

One of the defining elements of the Ecuadorian state between 2007 and 2012 is the implementation of structural economic reforms, including improvements in income redistribution and large-scale productive infrastructure. These are policy reforms that are typically associated with developmental states (Woo-Cummings, 1999; Ross Schneider, 1999; Johnson, 1980). Since 2007, there have been significant efforts at redistribution and structural policies aimed at transforming the basic economic characteristics in the country, both from the productive and social 
sides of the economy: these include substantial tax reforms (a more progressive tax structure and a notable improvement in collecting taxes), labour law reforms (mainly pro-labour laws like the regulation of outsourcing and social security reforms for the protection of workers' rights) and the expansion of welfare payments.

In addition, there have been many significant socio-economic reforms aimed at tackling poverty and inequality. According to ECLAC, Ecuador is one of the leading countries in recent years in combatting poverty. In 2011, for instance, it ranked second in the rate of poverty reduction in 2011 with a $3.7 \%$ reduction in its poverty rate; likewise, it ranked first in the rate of social expenditure devoting $11 \%$ of its gross domestic product (GDP) to the social sector (ECLAC, 2012a: 13; El Telegrafo, 2012: http://www.telegrafo.com.ec/economia/item/la-inversion-publica-delecuador-lidera-en-la-region.html). In fact, between 2006 and 2012 public expenditure increased six-fold, from approximately two billion to over eleven billion dollars (Velez, 2013: 19). Similarly, since 2007 the state has undertaken a sustained effort at economic redistribution. In the same period (2010-2011), according to ECLAC, Ecuador was one of the few countries in the region (along with Argentina, Brazil, Colombia and Uruguay) to experience a statistically significant reduction in inequality (although inequality levels in Ecuador remain relatively high by regional standards (ECLAC, 2012b: 21).

A second defining characteristic of the post-2008 state that could be characterized as "developmentalist" has been the emphasis on developing largeand medium-sale scale productive infrastructure projects. Notable examples are: 
the largest petroleum refinery in Ecuador in the coastal region, the Refineria del Pacifico; the largest hydroelectric project in Ecuador's history, the Coca-Codo Sinclair project in the Amazon region, along with six other large- and medium scale hydroelectric plants (Sopladora, Minas San Francisco, Toachi Pilaton, Delsira Nisagua, Quijos, Mazar Dudas) (Ministerio de Electricidad, 2012); the construction of a new international airport for the capital city of Quito and the most ambitions highway development effort in Ecuadorian history. These policies are accompanied by a series of programs broadly related to the principles of import substitution representing some of the fundamental characteristics of what I call here developmentalist policies.

Finally, there are additional issues worth mentioning in relation to the characteristics of neodevelopmentalism: first the role that economic growth plays in the development strategies of the state and second the role that extractivism plays in achieving growth. As Arturo Escobar notes in his analysis of the 2007-2010 PNBV, even if growth is at times portrayed as secondary and as being subordinated to other issues, most notably the right to preserve nature and culture (PNBV 20072010, as cited in Escobar, 2010: 22), the contradictions are "patently clear" (Escobar, 2010: 22). It is telling, Escobar notes "that the plan speaks of 'strategic areas' to amplify the ecobionic growth that can sustain human development...". These areas include: "energy, hydrocarbons, telecommunications, mining science and technology" (Ibid.). These areas are considered of strategic importance. For a (partially) developmentalist state like Ecuador "strategic" entails being exempt "from the cultural and environmental criteria that underlie the conception of the 
Sumak Kawsay/Buen Vivir" (Ibid.). In other words, economic growth and development in these "strategic " areas are intimately linked. This means that development in Ecuador since 2007, while different in important details from neoliberalism preserves the notion of growth as an economic organizing principle.

In particular, there is the question of economic growth and the role it plays in the construction of the state and its model of development. According to Alberto Acosta, the current version of extractivism in Ecuador is in fact, "part of a new version of South American developmentalism where the myth of progress under a new cultural and political hybridization is being maintained" (2010: 50). Following Acosta I would like to identify at least three fundamental characteristics of this relationship: first, the state portrays extractivism as essential for "development" and to fight poverty; second, there is a renewed and reinvigorated role of the state in the economic development of the country and in its role in the extraction of resources; and third, "social and environmental impacts of extractivist sectors are maintained and in some cases worsened" (Acosta, 2010: 50). Below, I briefly address these points one by one.

First, recently President Correa has insisted on the notion that extractivism is a kind of necessary evil (see for instance, WPR, 2012: \#286). It represents a step towards a better, post extractivist economic system. This is clearly reflected in the economic development model of the 2007-2009 PNBV in which extractivism is portrayed as a necessary step towards what the state in the 2009-2013 PNBV calls "bio-socialism" (PNBV 2009-2013, 2009: 33). This idea is also evident in Correa's and the government's discourse regarding extractivism. For example, according to 
Correa the potential extraction of petroleum from Yasuni National Park (the most bio diverse region of Ecuador and a protected area) could help lift Ecuador out of poverty, help with employment (WPR, 2013: \# 340).

Second, a crucial strategy of state construction that goes hand-in-hand with a developmentalist narrative of development is the recuperation and renegotiation of the tutorship over the exploitation of petroleum, which had, prior to 2008, been largely privatized by neoliberal policies. This means that since 2008 the state has been progressively more involved in all stages of petroleum exploitation: exploration, extraction and commercialization (see for example, Group Faro, 2012: 9). One of the implications of this enhanced role of the state is that rents from petroleum are directly captured by it without the interference of other societal groups. Unlike other countries that rely on exports (like South Korea, for example) the Ecuadorian state need not negotiate with non-state actors (i.e. producers) in order to obtain rents from exports - the sales of petroleum flow directly into the state apparatus.

Finally, in order to address the question of social and environmental impacts of extractivism it should be mentioned that the entirety of the petroleum exported from Ecuador is extracted from the Amazon region. Besides well-known potential and actual environmental problems associated with the exploitation of petroleum (see for example, Sawyer, 2004) in general, petroleum exploitation in the Amazon region has a series of peculiarities. First, it is Ecuador's most bio diverse and one of its most fragile ecosystems. Worth highlighting is the case of Yasuni national park where Ecuador's largest petroleum reserves rest. Yasuni is considered to be, relative 
to space, the most bio diverse place on earth and as well as a very fragile ecosystem (Ministerio del Ambiente, 2013). In addition, the Amazon region of Ecuador and Yasuni in particular, is home to many indigenous groups, some living in complete isolation from the rest of Ecuadorian society and whose cultural sustenance depends largely on their relationship to their territory. It is worth noting the importance that the concept of "territory" has for indigenous populations. Territory is a concept, in contrast to "land," that has both relations-of-production implications as well as cultural implications for indigenous populations. In other words, not only are indigenous livelihoods (food, shelter, work) dependent on the preservation of the natural resources in their lands, but their culture and cosmovisions are intimately linked to the wellbeing of their territory: for some indigenous peoples nature is a living being as much as human societies are (De la Cadena, 2010). This is precisely where the principle of nature-as-a-living-being comes from. Hence, the furthering of petroleum exploitation, as is the case in the current state, could entail a devastating impact on the cultural integrity of these groups as well as irreparable damage to the ecosystems of the Amazon.

Despite these issues the notion of development as enhancement of infrastructure, technology and productivity is deeply entrenched in the narratives of state formation. Developmental-state reforms are not only a question of actual pecuniary investment in infrastructure and/or technology, but about advertising it and bringing a narrative of state developmentalism across Ecuador. It is not an anomaly to travel on Ecuadorian highways and see large billboards announcing the details of state reform in this respect. As images 2 to 4 show, the discursive practice 
of the state is clearly developmental: the state and the "revolution" are linked to a specific notion of progress rooted in questions of modern infrastructure and modern technological improvement. The images shown below, for example, show the linkages made between the state, progress and things like modern highways, efficient airports and/or hydroelectric plants.

A developmentalist narrative that enhances the state as an engine of development and progress appears frequently on roads and other public spaces. Below are some of the billboards that appear next to many Ecuadorian highways. As the pictures reveal, the promotion of highways (Image 2), efficient airports (Image 3), hydroelectric projects (Image 4) and Import Substitution (Image 5) are directly linked to progress, a sense of belonging to the fatherland and Correa's citizens' revolution.

\subsection{The Modernizing Neo-Developmental State: Construing the Image of “Modern"}

The narrative of developmentalism goes beyond the organization of the state and policies like ISI and/or a "hyper" modern educational system. There is also a symbolic dimension to developmentalism that is worth mentioning. In 1979 Clifford Geertz, in a seminal study on Balinese cockfights, said that the state "not only powers, the state pomps" (Geertz, 1980: 65). For Geertz there were occasions in which state power served pomp and not the other way around. This meant that there were symbolic gestures performed by the state to enhance its status as social actor. Geertz's ideas in this sense remain important for the analysis of various acts 
of contemporary modern states. In the case of Ecuador, the launching of "Pegasus," its first Satellite, on April 25 th 2013, represents a case of developmentalist pomp.

Image 2. Developmental billboard: "We have first-rate highways. We have a Country!"

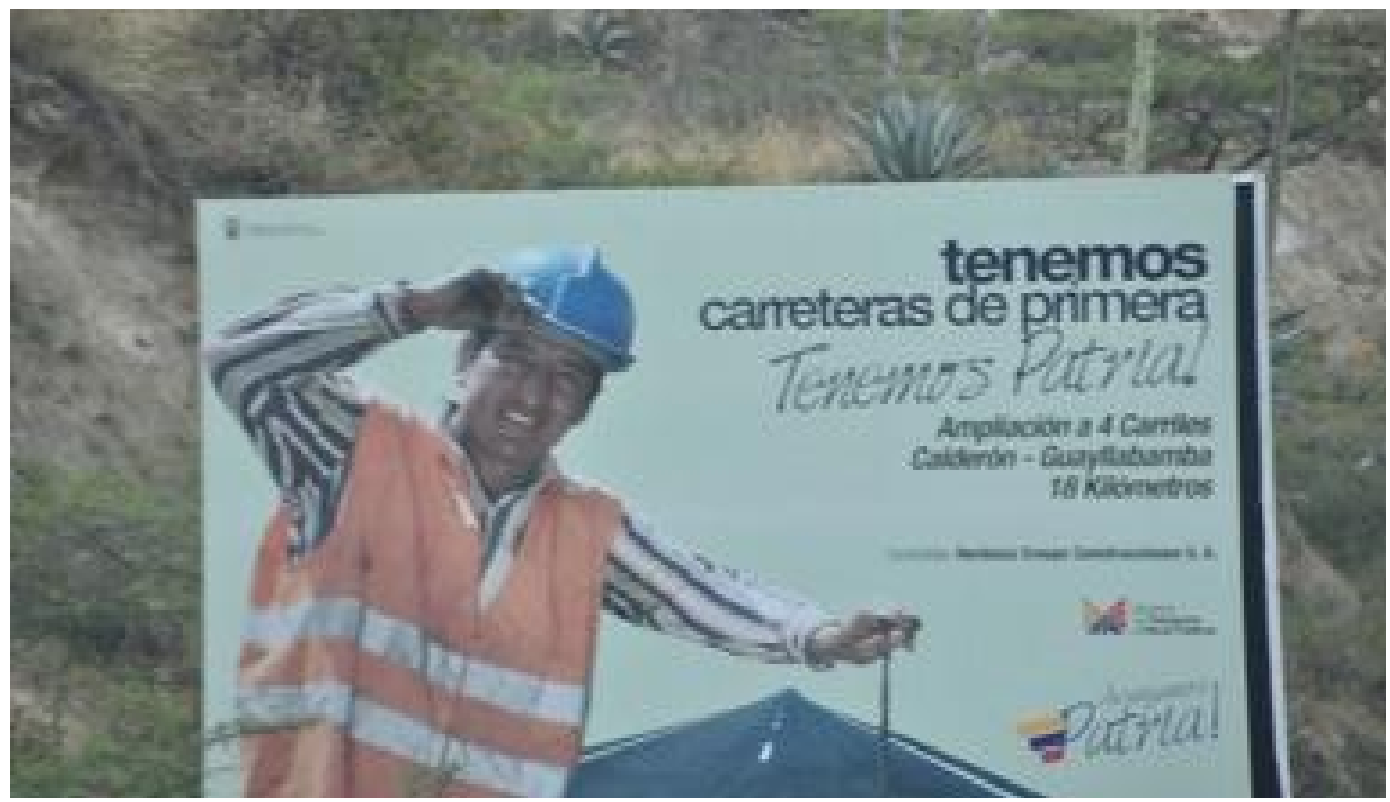

Source: Picture taken by the author in the Calderon-Guayllabamba highway, Ecuador 2013

Image 3. Developmental Billboard: "We Have Efficient Airports. We have a Homeland!

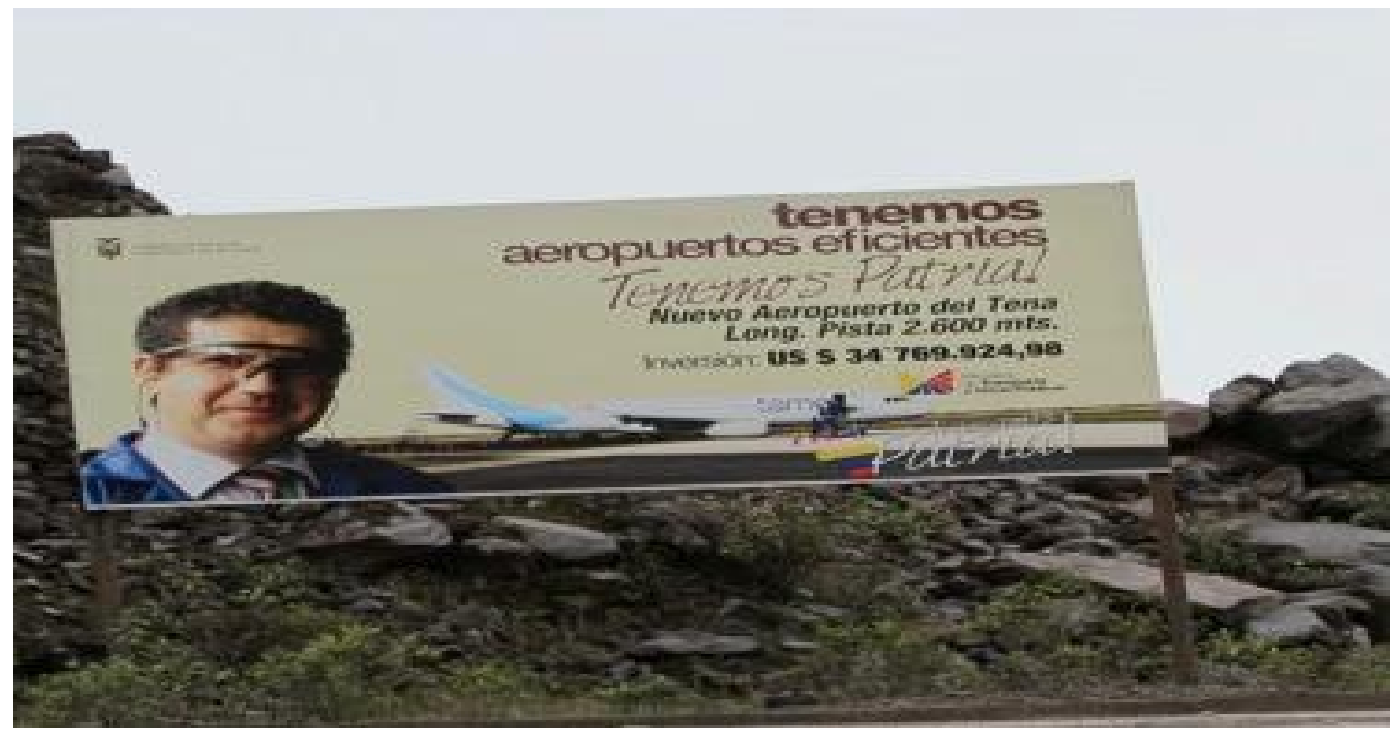

Source: Picture taken by the author in the Quito-Tena highway, Ecuador 2012 
Image 4. Developmental Billboard: "Electricity is Progress, like your Revolution"

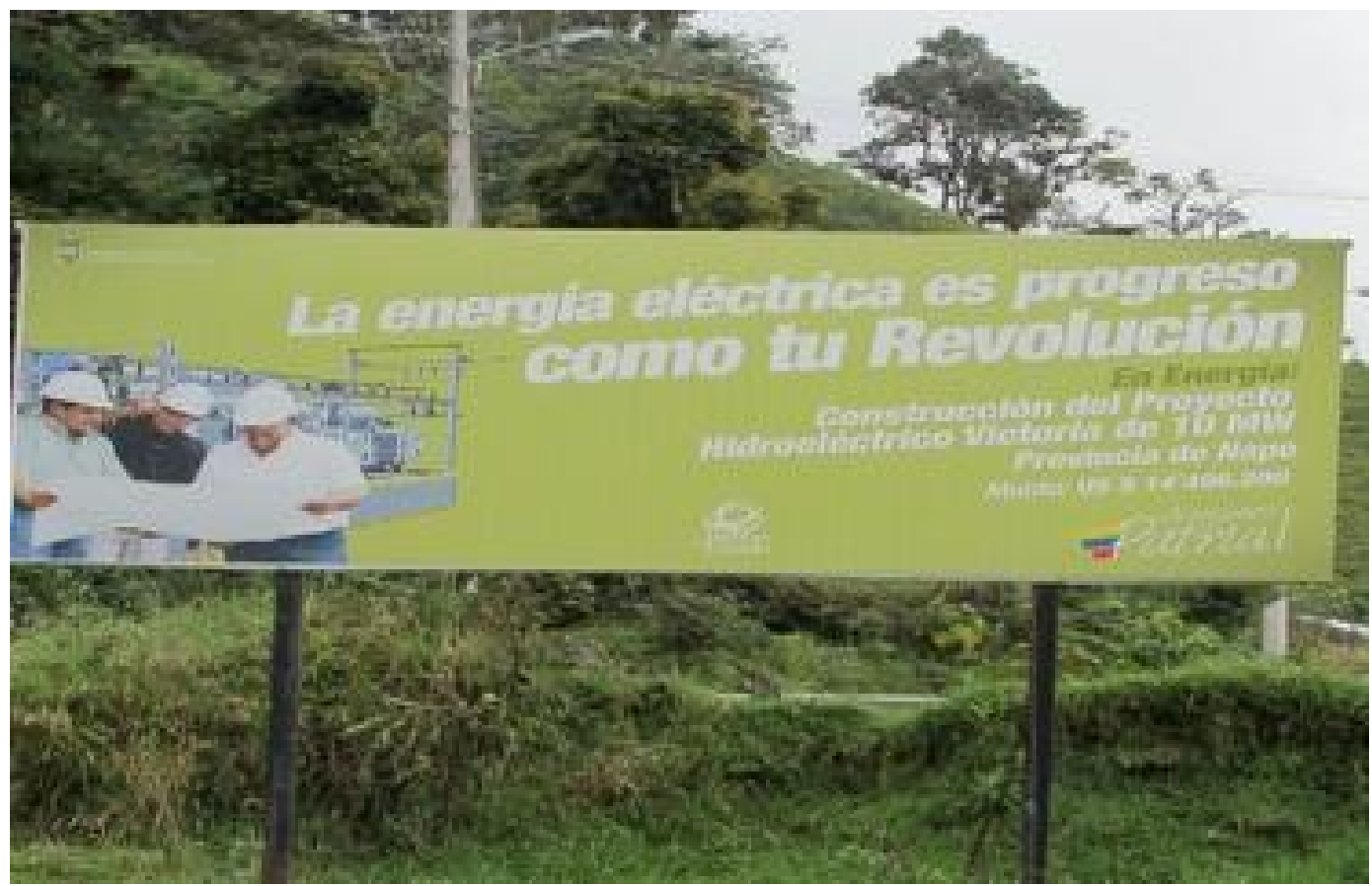

Source: Picture taken by the author in the Papallacta-Coca highway, Ecuador 2012

Image 5. Developmental Billboard: "Much Better if it is Made in Ecuador"

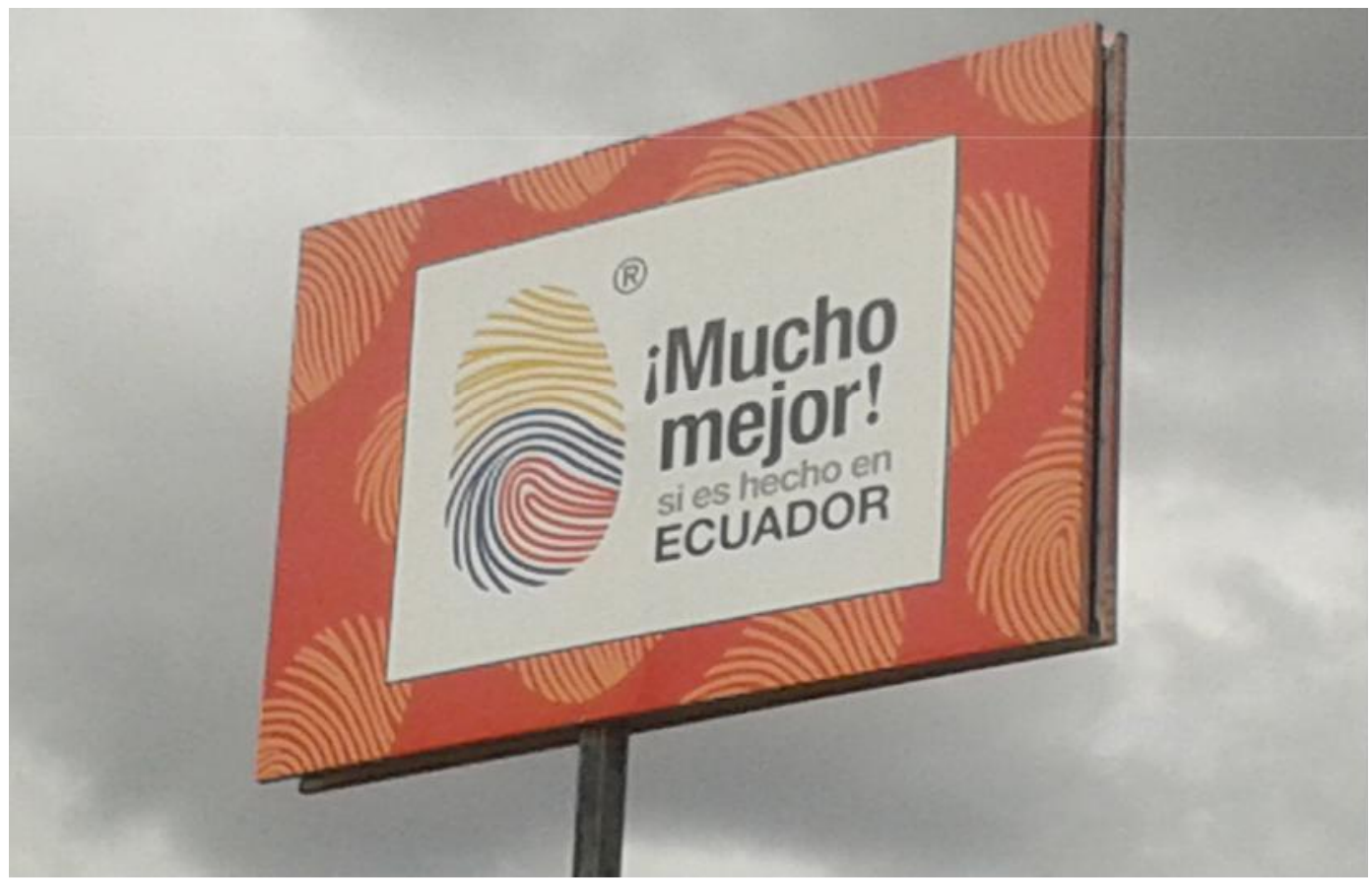

Source: Picture taken by the author in the Quito-Otavalo highway, Ecuador 2012 
The launching of Pegasus, from a realist point of view, is utterly unimportant in the sense that the launching of a satellite of the characteristics of Pegasus, is not, by any means, a technological leap forward. As a national newspaper weekly op-ed piece mentioned, satellites like Pegasus can be commonly purchased online in the United States. Ecuador's first satellite was, as the op-ed piece comments, built abroad and launched into space by the Chinese (Pallares, 2013: http://www.elcomercio.com/blogs/desde_la_tranquera/Pegaso-satelite-

Ecuador_7_910178976.html). However, from a Geertzian standpoint, the launching of Pegasus has much more to do with reaffirming its identity and presence in society as a force of a particular kind (developmentalist) than with the actual material benefits of the launch. Pegasus is a symbol of state fostered development.

Pegasus was launched into space, as I said, on April 25th, 2013 and the television images of the event projected to the country were telling. One of the most pompous ones saw the President Rafael Correa watch the deployment of Pegasus from a hall, designed, evidently, to emulate NASA's Launch Rooms (see for example, NASA, 2006: http://www.nasa.gov/mission_pages/shuttle/behindscenes/firing_room_4_f.html. The successful deployment of Pegasus (by a Chinese spacecraft from Chinese soil), much like well-known images of NASA's Launch Control Rooms), was followed by cheers, applause, hugs and the triumphant entry of the President into the "control room" (see the broadcast at http://www.youtube.com/watch?v=AJMiaShIoZA). Correa's entry was the climax of an event that represented Ecuador's supposed entry into the space age. 
Meredith Woo-Cummings (1999) notes that one of the characteristics of developmentalism is its almost obsessive relationship with technological development and industrialization. This relationship does not have to depend on actual technological or industrial accomplishments, however. There is also a symbolic component that is more pomp than power. The state is a theater in which actors and scripts around hegemonic narratives play out their parts and help reproduce the social bases of state support (Geertz, 1980). Along these lines another emblematic example of the concern for modernization understood in the terms stated above, is the development of Yachay. In short, Yachay is a large-scale, state-run, research village-university devoted to hard-sciences, specifically to the development of highly complex, technologically intensive knowledge creation and innovation for productive purposes. Yachay is, according to President Correa, the "most important project of his government" (WPR, 2012: \#276). Based on a similar project in South Korea, Yachay seeks to develop a "world-class" research centre capable of generating the knowledge base for Ecuador's productive transformation (Ibid.). As indicated in the following chapter, the state hopes to move from a primary-exports economic model of development to one centered on what they call "bio knowledge" as well as biotechnology (PNBV 2009-2013, 2010: 96).

According to Arturo Villavicencio, Yachay represents in many ways the state's understanding of modernization (Villavicencio, 2013). Yachay's website describes the project as "a planned city for technological innovation and intensive businesses in knowledge, where the best ideas are mixed in with human talent and 
state-of-the-art infrastructure that world-class scientific applications generate in the pursuit of Buen Vivir" (Yachay, 2013: http://www.yachay.gob.ec/yachay-la-ciudaddel-conocimiento). This description illustrates not only the emphasis on technological innovation and business, but the state's view of Ecuador's future insertion in the world economy as a generator of complex knowledge and an exporter of "bio-knowledge" and "bio products." (PNBV, 2009-2013, 2010: 94-98). Also revealing is the usage of "Buen Vivir," in the description of Yachay. Through its emphasis on becoming modern the state seeks to bridge two narratives about development that are largely incompatible: SK/BV and developmentalism (I deal with this issue at length in the next chapter). Finally, Yachay also conveys, in many ways, a somewhat dissonant reality of a low-income, poorly industrialized country, with an important number of ongoing social problems (in education, health, social infrastructure) seeking to insert itself in the world economy and global knowledgeproduction apparatus through some of the most complex and technical research areas like biotechnology, nanotechnology, biophysics, among others (see Yachay, 2013). Yachay denotes, moreover, mechanistic linkage between knowledge, technology, science and progress, which is, I would argue, a characteristic element of modernizing neodevelopmentalism.

The example of Yachay is perhaps the most emblematic illustration of the modern state but it is not the only one. This is not the place for a critical analysis of educational reform, but as Villavicencio (2013) argues, there is a unifying thread through the entire educational reform in Ecuador, particularly reforms concerning universities: there is an emphasis on modernization rooted in an uncritical stance 
towards scientific progress and foreign (mainly northern) educational models. This phenomenon is clearly expressed not only by the Yachay project, but also by the emphasis placed on hard science in the distribution of scholarships given to Ecuadorian students studying abroad (Villavicencio, 2013; Senescyt, 2013) in programmes such as Prometeo designed to bring foreign academics to Ecuador, as well as the direct "import" of academics from Spain in large numbers (El Comercio, 2013). In sum, the whole apparatus of graduate and postgraduate education is being structured under a narrative about "world-class" education, which, as mentioned earlier, takes an uncritical stance to educational models from the north and Asian Tigers, particularly from the United States and South Korea. Moreover, educational reform, I should add is embedded in the larger narrative about progress, academicism, and technocratic development that the state promotes. Put differently, educational reform responds, and provides further evidence of an important dimension of the Ecuadorian state, namely, its modernizing neodevelopmentalist tendencies.

\section{Conclusion}

An analysis of President Correa's narratives, as well as the state's symbolic practices shows a clear tendency to praise the qualities of the state as a developmentalist-modernizing institution. This grand narrative, however, is not enough to explain the ways in which the state behaves and its process of consolidation. Beyond Correa's narrative lies a complex state that is composed of multiple forces and actors. The state, furthermore, as argued in Chapter Two is 
never the state alone: the state is always a relational entity that must continuously redefine its boundaries through knowledge practices and techniques of intervention in society; there is, as Foucault says, a continuity between governing and governed people, an 'upward and downward' continuity (Foucault, 1991) which forces the state to formulate a multiplicity of knowledges and techniques for conceiving and defining populations, their problems and ways to improve them. This means that the state goes beyond the formal institutions that compose it and is composed of knowledge-techniques and practices that are not necessarily identical to the formal regulations that compose it (like the body of the law). Formal institutions are broken, interpreted, reinterpreted, interrupted and given concrete existential form through regimes of practices and these regimes are inseparable from the mentalities/discourses, knowledge and techniques that define their conditions of existence.

Finally, in the previous sections I also addressed the differences between the two most important narratives that have made up the processes of state formation since 2007. I have argued that there are important tensions between these narratives and that, as Arturo Escobar puts it, these differences are crucial to understand the post-neoliberal state in Ecuador (Escobar, 2010). One of the central tensions between the two narratives of state formation relates to the role that participation (understood as the politicized engagements of organized popular sectors, particularly indigenous peoples) plays in processes of state and policy formation. On the one hand, modernizing neodevelopmentalism stresses growth, infrastructural development and the development of a technocratic, modern state to 
accomplish it, and on the other, Sumak Kawsay/Buen Vivir, which emphasizes, as Acosta mentions, the re-politicization of social forces, particularly those who have been traditionally marginalized from and by the state - like indigenous peoples (see Acosta, 2009). The following chapters address the issue of governing participation more directly. Specifically, one of my central contentions, rooted in the information provided in this chapter will be that the government of participation is largely congruent with the modernizing developmental ethos of state formation mentioned above. 


\section{CHAPTER FIVE}

\section{CONSTRUCTING THE STATE THROUGH GOVERNMENTAL REGIMES}

\subsection{Introduction}

A central theoretical contention of my work is that the state can be regarded as a series of governmental regimes. Studying the state, therefore, entails, in part, studying the way in which regimes of government are constituted through regimes of knowledges about specific populations. One of the central aspects of a governmentality-inspired analysis of state formation is a focus on the relationship between knowledge, government and populations. Governmentality scholars have emphasized the role that knowledge plays in the constitution of populations and in the ways in which specialized state agencies establish governmental regimes through acts of problematization, techniques of intervention and regimes of knowledge. Moreover, governmentality scholars, particularly Tania Murray-Li (2007, 2010), have emphasized the linkages between governmentality and improvement. The concept of improvement is useful insofar as it allows one to analyze governmental interventions and the government of populations as a complex relationship rooted in the active and wilful participation of state as well as non-state actors in the constitution of regimes of rule. Rule through improvement, I will argue, is part of the mode of power which Foucault calls "government" (Foucault, 2004; Walters, 2012).

To understand processes of state formation one must address the role of specialized agencies in the formulation of governmental regimes understood as 
regimes of improvement. Thus, in the following sections I analyze the work of one such agency: the National Secretariat for Planning and Development (SENPLADES). More specifically, however, I focus on the central participatory planning product developed by SENPLADES: the Plan Nacional del Buen Vivir (PNBV). I focus on the formation of the 2013-2017 PNBV but pay attention to previous versions of the plan as well.

\subsection{Governmental Regimes and Improvement: Developmentalism as a Regime of Improvement}

Before moving on I would like to draw a parallel between what, following Tania M. Li (2007), I call regimes of improvement and developmentalism. In particular, I argue that in the case of Ecuador modernizing-developmentalism could be understood as a regime of improvement. Regimes of improvement are assemblages of discourses, practices, mentalities and techniques that define the ways to (and not to) improve subjects within a specific field (Li, 2007a: 10-16). From a Foucauldian point of view, regimes of improvement are also imbued with power implications in that they are intended to transform individuals in particular ways through self-improvement, not force, coercion, punitive acts or even laws. It also entails that, unlike repressive, authoritarian regimes, like Ecuador's Hacienda State or South Africa's Apartheid state, where oppressed subjects were considered to be beyond improvement, regimes of improvement regard people as capable of being corrected, bettered.

The bio political component of a regime of improvement comes in that improvement is obtained through the government over life, wellbeing, health and 
generally, processes that turn humans into productive beings (Foucault, 2009). From the perspective of Foucault's theorization on the subject, improvement and government are linked because once "improved" subjects behave in certain ways without being told to do so and without necessarily being conscious of it (Walters, 2013; Li, 2007; Hindess, 2001). I should note that improvement, like the governmentalization of the state, is a process not an overnight event. It is important to remember that governmentality is not simply withdrawing or eliminating state agencies and letting individuals self-govern through market incentives, but a construction that is fundamentally influenced by the actions of the state.

The contemporary Ecuadorian state, I would argue, is fundamentally characterized by this governmental ethos. It is, unlike the Hacienda or Oligarchical, or dictatorial states of the past, rooted or defined in terms of the exclusion of certain populations: indigenous peoples, communists, Afroecuadorians etc. An important characteristic of the contemporary state is its attempt, albeit important practical and conceptual tensions, to broaden the rights of minorities (Constitution of Ecuador, 2008: Art. 2) and the base of individual rights in general (Constitution of Ecuador, 2008: Art. 35-55). Moreover, a number of aspects of the post-2007 state are fundamentally linked to a biopolitical regime of improvement aiming at the well being of the population at large. This involves the government of life through, education and health.

The combination of a broad base of individual rights and a developmentalist strategy of development suggests that the ethos of modernizing-developmentalism is not exclusion for its own sake but the partial and progressive inclusion of 
segments of the population on the basis of their improvement. Later in this chapter I provide further evidence of this by conducting an analysis of the state's relationship with indigenous opposition to extractivism, the economic source of developmentalism. The response of the state to indigenous peoples' opposition makes visible an aspect of the anti-politics as exclusionary practices are performed under the guise of a rhetoric of inclusion and its disciplinary, not authoritarian character.

I must also point out that I employ the term improvement to evoke Foucault's notion of improvement in individual bodies as the result of the administration and government of life (see Focuault, 2000: 217-237). I, however, utilize the term also to signify a movement from a particular regime of life to a "superior" one, one that fulfills the potentials of the bodies of individuals and society as a whole. I argue that the Correista state's governmental ethos regards the incorporation of populations into its modernizing-developmentalist regime as a form of "improvement." In this movement no one is a priori excluded. And, as mentioned above, the emergence of state agencies capable of generating knowledges about populations to be improved, techniques of improvement and discourses of improvement are essential. Consequently as one investigates the Ecuadorian state one should expect to find the emergence of such agencies. And indeed in the areas of participation and education this is what one finds. In the following section I analyze the case of SENPLADES.

\subsection{Discourses, Knowledge and the State}


One of Foucault's major contributions is to show how fields like "the economy," "health," and so on, became governable spaces. Economics, education, health and so on, are not a priori domains existing "out there." To the contrary, Foucault convincingly shows how some of these fields became problematized in order to better comprehend how, in turn, they became governable fields. A central aspect in this process of "creating government," so to speak, has to do with the development of various types of knowledge about governable fields, like the economy, health or education. Moreover, as Walters (2013) points out, government requires knowledge and also techniques, standardized procedures, etc.

In this sense, acts of government are, in part, acts through which states, or other institutional formations, apply their techniques, practices and knowledges in an "artificially" constituted field of intervention. Thus, looking at this issue from a governmentality perspective one would expect to see the creation of specialized agencies capable of developing and applying highly technical knowledges over defined fields of intervention and populations. As we will see below, mainly through an analysis of SENPLADES and Senescyt, an important characteristic of the contemporary state is, precisely, the presence and importance of highly specialized, technical offices that develop techniques, knowledges and procedures in order to govern. Hence, and in so far as the state can be defined as "the mobile effect of a regime of multiple governmentalities" (Foucault 2008: 77) the work of SENPLADES is very much to build an idea of the state.

\subsection{Defining Governmental Regimes: The Case of SENPLADES}


In this section I will employ two methodological techniques to develop an analysis of SENPLADES and link its work to processes of state formation. I will look at SENPLADES, through a governmentality-as-a-form-of-political analysis (Walters and Haahr, 2005) approach. Specifically, I analyze the ways in which SENPLADES articulates the diverse actions, knowledges and discourses about "the state." Moreover, I look at the ways in which something as multifaceted, complex and dispersed as "the state" is made into a coherent "being" through the work of a specialized agency and how something as abstract as "the state" is territorialized through governmental techniques. Moreover, I analyze the micro-spaces of power and government and how SENPLADES articulates into a form of government. To do so I analyze one of the main themes of this dissertation, namely, the participatory construction of the 2013-2017 Plan Nacional del Buen Vivir (PNBV).

\subsection{SENPLADES and the Articulation of the $s$}

In the early 1990s, during the neoliberal period, Conam, the Consejo de Modernizacion del Estado (Council for the Modernization of the State) was created. As the state agency whose mission was to modernize the State, CONAM was in charge of privatizations and reducing the size of a supposedly "inefficient" State. In its own particular sense of the concept, CONAM was in charge of making the State more efficient. In 2007, the Secretaría de Planificación y Reforma del Estado (SENPLADES) replaced CONAM. ${ }^{21}$ Through the reforms enacted by the new government and the Constituent Assembly of 2007, SENPLADES was ratified as the

${ }^{21}$ SENPLADES emerges to replace Conam but it is also merged with the Consejo de Planificación del Estado created in 2004. 
government's main planning agency.

At this point I would like to refer back to some of the theoretical points mentioned in Chapter Two about governmentality and the state. Mainly I want to problematize the notion of what articulating the state means. The state is not a reified entity that simply exists "out there," apart from its sources of legitimation, cohesion and reproduction; apart from relations of power both at the macro and micro levels (Jessop, 2007). While it is indeed difficult for states to completely collapse or disappear, states can be weaker or stronger, have more or less capacity to penetrate society; have more or less capacity to act upon and manage its populations; to either foster development and or discourage it. states are always incomplete processes not things.

In this picture, knowledge produced from within the state is crucial for its reproduction. If one views the state as a multiplicity of governmental acts, as a relation of power and an effect of social relations, then knowledge is the sine qua non of a process of state formation. Knowledge production allows the state, as mentioned earlier, to define problems, specify areas of intervention, calculate resources, and determine political goals (Lemke, 2007: 3). Knowledge production, its accompanying discourses and "inscription devices" allow the state to govern. And areas of government like the state are not pre-social spaces existing "out-there." These areas of intervention must be constructed, defined, made intelligible and for that the state must know. Thus knowledge production and specialized agencies are important insofar as they make the presence of the state itself relevant. 
In this sense, one the main tasks of SENPLADES has been to define the parameters of the state and produce knowledge in multiple areas. Take for instance the following statement about the state:

In previous decades the state reform was conceived only as a process of privatization that led to the weakening of the state ... the democratic reform of the [current] state departs from the premise that a new strategy of development requires a new state model and the recuperation of its public dimension, which is something that requires changes in state governance in order to facilitate the democratization and efficiency of public administration (SENPLADES, 2012: http://www.planificacion.gob.ec/wpcontent/uploads/downloads/2012/08/SENPLADES-Que-hacemos-yquienes-somos.pdf)

In this passage SENPLADES establishes two important discursive cornerstones of the post-2008 state: its opposition to a straw-man depiction of neoliberalism (that is, opposition to a limited understanding of neoliberalism as privatization) and that the solution is a new, stronger state capable of recuperating its "public dimension." In short, it established the need for a new state and the fundamental connection between the public and the state. As I argue in Chapter Four, this linkage between the state and the public is a central discursive construct that has spearheaded the dismantling of various indigenous peoples' organizations like the National Directorate for Intercultural Bilingual Education - DINEIB.

Furthermore, this story suggests that the state needs to be reinvigorated and 
that SENPLADES must play a role in such process. Knowledge-producing agencies are crucial to the opening up of governmental spaces of intervention. Thus, what one should expect from an agency like SENPLADES is to be involved in the creation of technical knowledge about these governmental areas. Table 1 below shows a sample of important publications, seminars and research projects undertaken by SENPLADES between 2008 and 2013.

Table 1. The Knowledge Production of SENPLADES

\begin{tabular}{|c|c|c|}
\hline Area of Knowledge & Title & Subject \\
\hline State Planning & “PNBVs 2007-2017”22 & Development Plan \\
\hline State Reform & $\begin{array}{l}\text { "Recuperación del Estado } \\
\text { para El Buen Vivir" }\end{array}$ & $\begin{array}{l}\text { Recuperating the state } \\
\text { after neoliberalism. }\end{array}$ \\
\hline Environment & $\begin{array}{l}\text { "Aportes para una } \\
\text { estrategia ambiental } \\
\text { alternativa" }\end{array}$ & $\begin{array}{l}\text { An alternative } \\
\text { environmental strategy }\end{array}$ \\
\hline Geography/Territory & $\begin{array}{l}\text { "Lineamientos para la } \\
\text { Planificación del } \\
\text { Desarrollo y el } \\
\text { Ordenamiento Territorial" }\end{array}$ & $\begin{array}{l}\text { Territorial ordering, state } \\
\text { planning and } \\
\text { development. }\end{array}$ \\
\hline Political Theory/Doctrine & $\begin{array}{l}\text { "Socialismo y Sumak } \\
\text { Kawsay" }\end{array}$ & $\begin{array}{l}\text { Political theory: socialism } \\
\text { and Sumak Kawsay }\end{array}$ \\
\hline Participation & $\begin{array}{l}\text { "La participación } \\
\text { Ciudadana" }\end{array}$ & Participation and the state \\
\hline Public policy & $\begin{array}{l}\text { Guía para la formulación } \\
\text { de políticas públicas }\end{array}$ & $\begin{array}{l}\text { Guide for formulating of } \\
\text { public policy }\end{array}$ \\
\hline Education & $\begin{array}{l}\text { "Seminario Internacional } \\
\text { de Evaluación y } \\
\text { Acreeditación" }\end{array}$ & $\begin{array}{l}\text { Educational reform, } \\
\text { accreditation and } \\
\text { evaluation seminar }\end{array}$ \\
\hline
\end{tabular}

22 Includes three distinct PNBVs: 2007-2010, 2009-2013, 2013-2017. 


\begin{tabular}{|l|l|l|}
\hline International Relations & $\begin{array}{l}\text { "Ecuador notificará inicio } \\
\text { de negociaciones para } \\
\text { adhesión a Mercosur" }\end{array}$ & $\begin{array}{l}\text { International trade, } \\
\text { regional integration. }\end{array}$ \\
\hline $\begin{array}{l}\text { Technological } \\
\text { management }\end{array}$ & $\begin{array}{l}\text { "Reglamento para } \\
\text { activación, uso y control de } \\
\text { los activos de tecnología" }\end{array}$ & $\begin{array}{l}\text { Regulatory body for the } \\
\text { usage and control of } \\
\text { technological assets. }\end{array}$ \\
\hline Development & "Nuevas Estrategias & $\begin{array}{l}\text { New Developmental } \\
\text { Strategies }\end{array}$ \\
\hline Art/Culture & "Memales de Desarrollo" Bienal" & Art exhibit minutes \\
\hline Economics & "A Redistribuir Ecuador & $\begin{array}{l}\text { Economic redistribution } \\
\text { and economic planning. }\end{array}$ \\
\hline Sara Todos" & & \\
\hline Statistics & "Systema de información" & $\begin{array}{l}\text { Statistics and social } \\
\text { indicators }\end{array}$ \\
\hline
\end{tabular}

Source: SENPLADES, 2013: http://www.planificacion.gob.ec/biblioteca/

As is evident from Table 1, there is a wide range of areas of knowledge in which SENPLADES “intervenes.” Whether directly or indirectly these "interventions" are characterized by the creation of knowledge about areas of potential or actual governmental intervention, about its populations and the techniques which will be used to confront the problems that government is there to solve. SENPLADES's work is fundamentally linked to acts of problematization and the generation of technical solutions to social, cultural, economic and political problems. Of the publications mentioned above, the majority, if not all, could be described as forms of deployment of specialized technical knowledges. SENPLADES is a technocratic organization that is largely responsible for rendering issues technical: rendering problems "solvable" 
and establishing the techniques to carry out the task of solving them (cf. Dean, 1999; cf. Li, 2007).

I should also note that the multiplication of areas for governmental interventions is not simply an imposition by an all-powerful state over its population. Although the state can and sometimes does impose its will over society, the degree to which it can do so is limited by many factors, like legal restrictions, economic scarcity, a strong politicized society capable of limiting the actions of the state, the international community and so on. However, the state also disposes of other means of rendering issues less polemical, of easing its way into society. One such way, as Li (2007b) argues is to render issues technical (cf. Ferguson, 1994); in combination with rendering things technical the language of SENPLADES is that of improvement and development. The work of SENPLADES is, therefore, concerned with expanding areas of government through a governmental logic of improvement and technocratic knowledge.

In the mode of power called "government" (in the Foucauldian sense of the term), rendering issues technical is a fundamental aspect of its own exercise. Rendering technical, as Li (2007) points out, entails "extracting from the messiness of the social world, with all the processes that run through it, a set of relations that can be formulated as a diagram in which problem (a) plus intervention (b) will produce (c), a beneficial result" (Li, 2007: 265). The process of rendering technical is intimately linked to anti-politics. As Li notes, "anti-politics" entails "reposing political questions as matters of technique; closing down debate about how and what to govern and the distributive effects of particular arrangements by reference 
to expertise; encouraging citizens to engage in debate while limiting the agenda" (Ibid.).

\subsection{The Reconfiguration of Rule: SENPLADES and the "De-concentration" and "Decentralization" of the State}

One of the central tasks of SENPLADES has been to conceptualize and design what they call de-concentration and decentralization of the state. De-concentration and decentralization are defined as the reformulation of state practices for the progressive assumption of governmental responsibilities by sub-national governments. However, at another dimension it implies the reconfiguration of rule through the re-spatialization of the state, its territory and its population. More specifically, as a planning agency SENPLADES has worked on the redistribution of spaces according to new territorial and demographic units called zones, districts and circuits. This redistribution of spaces is designed to have a direct impact on planning and participation, and, importantly, over the way the state and populations are governed.

As I show later, this re-spatialization of the state contributed to selecting and defining the populations in the participatory processes in the PNBV. One of its central aspects is its focus on micro spaces through the creation of politicoterritorial units called "circuits." Circuits are territorial units composed of an average of 11.000 inhabitants and 1.134 circuits in the entire country (SENPLADES, 2012: http://www.planificacion.gob.ec/folleto-popular-que-son-las-zonas-distritos- 
y-circuitos/J.23 This means that the territorial rearticulation of the state has a welldefined micro-governmental dimension, meaning that the state is now present in smaller demographic/territorial spaces. President Correa highlighted this fact during WPR number 295. According to Correa, the state is now able to engage in micro planning. Put differently, state planning reconfigures how government can be articulated in specific populations. Through the re-spatialization of territorial units in relation to the state, "government" is now a micro as well as a macro activity.

But what is important to highlight here is that this reconfiguration of forces is not presented or conceptualized in terms of control but in terms of management and planning (cf. Valdivia, 2005). These are, as argued in Chapter Two, two different logics of rule. An important dimension of reconfiguring the state spatially is the relative autonomy of smaller units. Autonomy in this sense is understood as the selfmanagement of resources, not political autonomy from the central government. Effectively this means a reconfiguration of rule in which the central government is less directly involved in the government of small territorial units but no less capable of managing populations and exercising its rule through them - an instance in which "less," actually means more government.

\subsection{Participation, Indigenous Peoples and the Re-Spatialization of the State}

Two important questions regarding SENPLADES's territorial reconfiguration of the state are: what are its mentalities and constitutive logic? (cf. Ruggie, 1998; Gordon, 1993) and how does it relate to the participation of marginalized populations,

\footnotetext{
${ }^{23}$ Ecuador is 283,520 square kilometers and one of the smallest countries in South America (fifth smallest). Its population is $14,483,499$ inhabitants.
} 
particularly indigenous peoples. Like in various other institutional aspects of the state since 2008 one finds that the central narratives of de-concentration and decentralization are constructing a more efficient state and the development of Buen Vivir. According to SENPLADES the benefits of decentralization and deconcentration are:

1. Bringing the state and state services closer to communities

2. Guaranteeing territorial equity, as state services and their administration will be planned from within each territory, "according to the demands of the citizenry in order to achieve certain living standards and Buen Vivir."

3. An improved management and optimization of resources in each territory

4. Allows for nation-wide planning and organizing according to a territorial vision.

(SENPLADES, 2013: http://www.planificacion.gob.ec/4-como-nosbenefician-las-zonas-distritos-y-circuitos/)

Conspicuous in this approach, however, are absences in relation to the principles of indigenous peoples' territorial and political autonomy - issues directly linked to the participation of indigenous peoples in processes of public policy and state formation. As mentioned in Chapter One, one of the central demands of indigenous peoples, particularly CONAIE, is the recognition of indigenous territorial claims and their recognition as nations within a plurinational state. Indigenous struggles in this respect did lead to legal transformations of the concept of the state in the Constitution of 2008: the first article of the Constitution defines Ecuador as a plurinational state (Constitution of Ecuador, 2008: Article 1). Notwithstanding, as 
maps 1 and 2 below show, the concept that indigenous peoples have of the nation and the state's representation of territory in relation to state efficiency and equity, do not coincide and is far from the representation of the state as a plurinational entity. More specifically, what the maps make evident is the tension of representations: indigenous peoples self-representation requires the opening up of a politicized spaces where radical changes to the cultural, territorial and political matrix of the state can be discussed, debated, fleshed out. By contrast the state's representation of territory defines territory as a space for governmental intervention that is accessible from the perspective of the government's technical means and knowledges. This tension makes evident the depoliticizing tendencies of the state's governmentality.

Most indigenous activists I interviewed alluded to the detrimental effects that the re-spatialization (i.e. the re-imagining and ordaining of boundaries within regions, including the re-organization of jurisdictions for policy-making) the undertaken by SENPLADES could have on communities and small organizations. Moreover, according to an indigenous activist working on educational reform and representative of an important indigenous organization in Ecuador indigenous children from the same nationality or pueblo may be "forced" to attend school in different circuits. This takes place because some schools are closed and others opened in different locations according to the territorial division based on criteria like efficiency. My interviewee perceived this situation as a "new form of colonization" (Anonymous Interview, Quito, November 14th 2012 ) as this respatialization would separate communities. This point was shared by another 
indigenous activist and expert who contends that reformulating spaces according to SENPLADES' logic will have a clear effect on the ability of indigenous peoples to implement educational policies according their cultural needs. Furthermore, in his view even if the government were to accept the precepts of intercultural education as proposed by indigenous organizations (something that is not occurring) the policies emerging out of such an acceptance would contradict the principles as the territorial divisions obey a mentality that first and foremost seeks to reinsert the state as a provider of services and not as a radical, participatory social agent capable of fomenting SK/BV-inspired changes (Anonymous Interview, Quito, November $14^{\text {th }}$, 2012; Anonymous Interview, Quito, November 19th 2012) (see also Maps 1 and 2).

I should emphasize here the importance that these two different mentalities have on reformulating space: on the one hand, SENPLADES' efficiency-oriented respatialization, and on the other, CONAIE's and the indigenous movement's view based on nationalities' and peoples' good living/well being (buen vivir). While SENPLADES seeks to reinsert the state as a provider of services for populations (understood as a collection of individuals), CONAIE understands space as a question of cultural reproduction (Yanez, 2006, cf. Lopez, 2006). The difference lies, as the indigenous expert and activist stated, in the homogenization of populations populations are not conceived according to the reproduction of their culture and ways of life. (Ibid, 2012). As I document later, the re-organization of the state's territory according to zones, districts and circuits was translated into practice in the workshops during the PNBV. The participants in the PNBV, including indigenous populations, were highly fragmented, as a consequence of the workshop's failure to 
emphasize the importance of belonging to a popular organization. It could be said that the individuals participating in the workshops were largely representing themselves or a small sector of their communities. There were no systematic linkages established between civil society organizations and workshop participation. As I argue below this further reveals the administrative logic of management of populations developed by SENPLADES.

\subsection{SENPLADES and Government}

Unlike disciplinary techniques often employed by the state or liberal techniques of "self-responsibility", governmentalized agencies employ tactics, like rendering technical, anti-politics, re-spatialization, knowledge creation and problematization to intervene in society in the name of its own improvement. Not unlike approaches carried out by the aid industry (see Burchell et al. 1991) the creation of state agencies exercise power beyond their juridical attributions and beyond the capacity of the state to police and impose its will on the population. And, following Foucault (1980: 122-124) it could be argued that the constitution of the modern state and the invention of modern governmental reason entails that power is exercised with the active participation of those who are the objects of control. Specifically, Foucault argues that the state is not (and cannot be) the source out of which power emanates, or the source where power is captured and possessed. The state is an effect of power, not its origin.

I am not suggesting here that SENPLADES, or the government of Ecuador do not face opposition what I have been trying to convey is the patterns (in terms of 
power and strategies) that the Ecuadorian state has followed, since 2007. I have been showing that statecraft from the perspective of the state has followed a governmentality-type of process. This is not to negate that the state faces opposition and/or that people exercise their agency to overcome, refute, and negate governmental interventions because they do. Notwithstanding this obvious point (that people always, albeit in different ways and times, resist power), the question I am trying to answer is, not about whether or not social forces outside of the state are effectively controlled but rather, what trajectory and power modalities the state has followed in its own construction since 2007.

I should note here, following Li (2007a) that my contention here is not that SENPLADES necessarily looks at depoliticization as a goal or overt objective. As one high SENPLADES official contends, political participation by social forces is regarded as a positive thing (Anonymous Interview, Quito June 10 $10^{\text {th }}$, 2012; Anonymous Interview, Quito, February 14th 2014$)$. However, I argue that depoliticization is part of a governmental ethos, which characterizes the post-2008 Ecuadorian state; it is a central aspect of the unfolding of the state's construction rather than a strategic calculation by the government - although such a calculation may occasionally be undertaken (see Chapter Six). The point to be taken from my analysis of SENPLADES is how this state agency performs a fundamental task in the process of statecraft. Through the case of the PNBV I further analyze the ways in which SENPLADES practices its governmental tasks and how those practices are part of a larger mentality of government that is characterized by its depoliticizing tendencies. 
Map 1. Indigenous Peoples Territorial Self-Representation: Indigenous Nations and Peoples

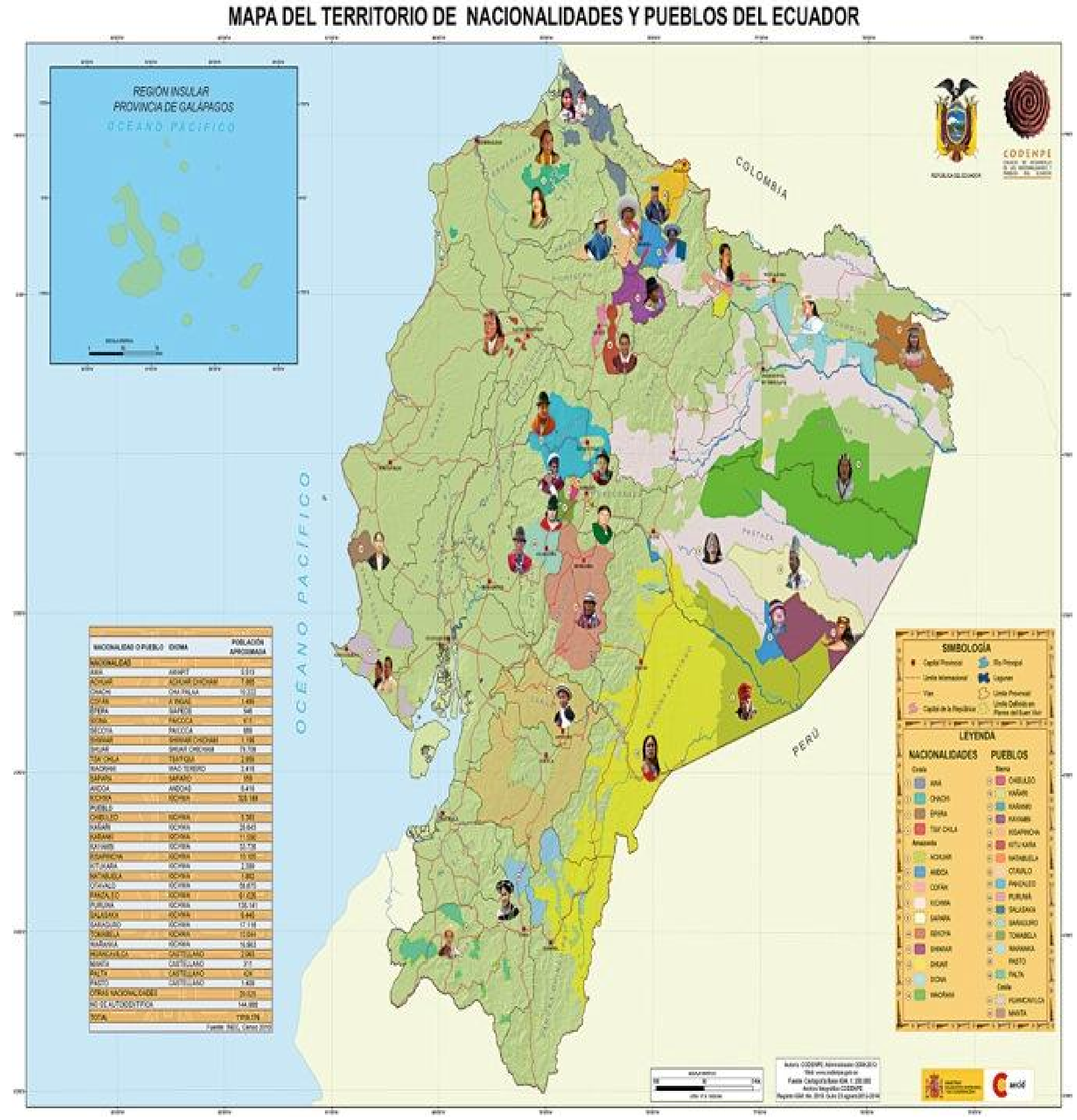

Source: Codeine, 2013:

http://www.codenpe.gob.ec/index.php?option=com_content\&view=article\&id=125\&catid=96 


\section{Map 2: Representation of Territory by SENPLADES: Zones, Districts and Circuits}

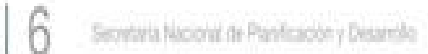

Niveles administrativos de planificación

Dara acercat el Etasos a toda us cudadaria, a traves de la prestación de
participermos tedos y todos.

Con este propisto, la Secretaria Nadinal de Flanfítación y Desarrolo SENFLADES, corlormo niveles sdminstrafives de planificaciobr zanas, distrites y circutos a nivei nacional que permitinin una mejor identifcación de residades y solucienes efestivas para la prestacion de servicios publicos en el teritoria. Esta scoformadón no mplea eiminar las provincias, cantones o parcusulas.

Las zonas estin conflormadas por provitcias, de acuerdo a una prouimidas geografica, cuturalyecoeómica. Tetemes 920 ns adminissativas deplaniffación Casi zena ests conssifuda por distritos y estos a sa vez por ceculos. Desde este nivel se coordina estratígcamente las entidades del sector púbico, a travis de la

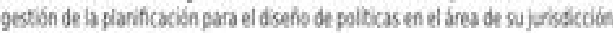
iver inforada pag. 7 )

E distrito es ia sridad busica de planteacito y prestasion de servicess poblices. Coincide con el cantbon o unián de carcones. Se hah cotlomado 140 dstritos en el pais. Cada distrito tiene un apreximado de 90.000 habitantes. Sin entarga, para cantoces tuya pablacich es muy ata coms Quto, Guapapalt. Cuenca, Revosto y Sarto Domingo de los Rachilas se esablecen distritos dentro de elos.

E circuito es la localisad donde el corfunto de servicos pübicos de caldas estah al akance de is cudaduria, esta cortomasa por la presencia de varios establecimientas on in temtorio dentro de un distrito. Conresponde a una partoquiz o conjunto de parroquas, exsan 1.134 circultos con un aproeimads de 11.000 tabicantes.

Las zonas. distritos y circutos son siveles desconsentrados para ladministracode

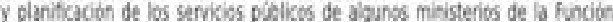
Eecutiva. fueron conformatos respetanso is dvisión polidica administrativa, es decir comesponte a una nueva forma de planficacion en el territorio más no a nueves tiveles de gablemo. Por b tyoto, los niveles de gobiems concervec atconowa y pobecnablisad a nivel de las provincias, cantones y samequas.

Los fiveles administrativas de planflcacito buscan centar con uns oferta idea deservicios tn el territorio sustertado en un Estado plan ficaso, dekconcentrado, articulado, equatativo, con maycr cobertura y calidad de servicios pablicos.

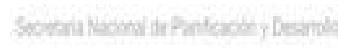

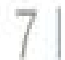

Zonas de planificación

\section{Мapa 3}

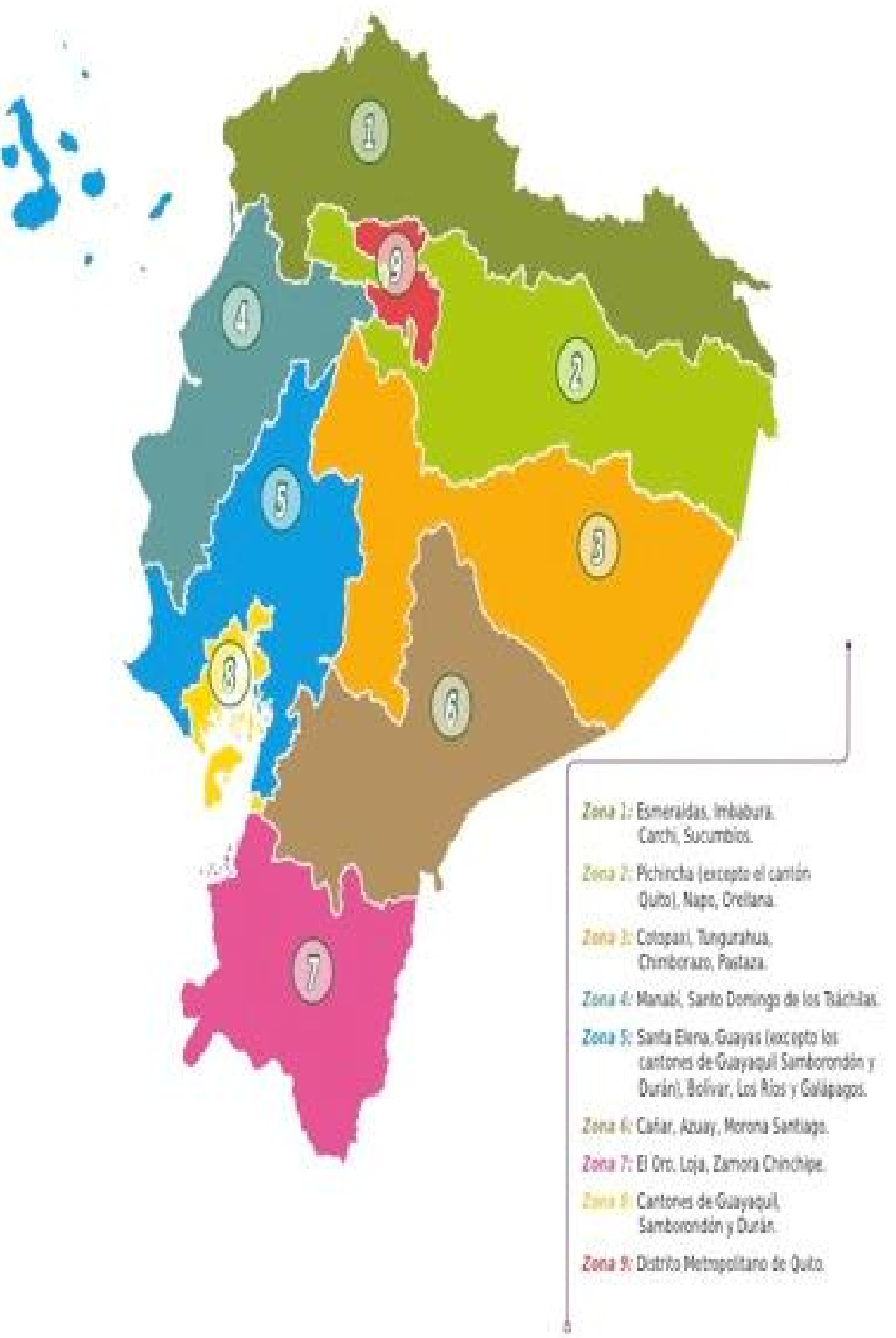




\section{SENPLADES, THE CONSTRUCTION OF A REGIME OF GOVERNMENT AND THE PLAN NACIONAL PARA EL BUEN VIVIR}

\subsection{SENPLADES and Reverse Auto-Ethnography and the PNBV}

To start this section I would like to bring back the issue of the narratives defining the Ecuadorian state since 2007. Earlier I had mentioned that two confronting narratives, modernizing-developmentalism and Buen Vivir, play important roles in not only defining the state formally but also in defining its regimes of practices and forms of government. The former runs through the very fabric of processes of state reform and forms part of a regime of improvement. But what about Sumak Kawsay/Buen Vivir? What role does it play? I proceed by analyzing precisely the way that SENPLADES through the PNBV articulates these "opposing" narratives about "development" in the country's most important state planning document. I argue that the balance in the tension between these narratives leans largely in favour of modernizing-developmentalism turning SK/BV into a functional element within a narrative about the self-representation of a state that defines improvement largely in terms of modernizing-developmentalism. In order to argue my points and analyze the evidence at my disposal I employ the concept of auto-ethnography into the analytics of government approach that I have been employing thus far.

In Chapter Two, following Mary Louise Pratt (1991) I developed the concept of "reverse auto-ethnography." Briefly, by reverse auto-ethnography I mean that in the hands of the state civilizational challenges (Pratt, cf. 1992; Leon, 2011) by indigenous peoples become devoid of their emancipatory content. In practice this means that the adoption of the language and symbols of indigenous peoples has 
played a fundamental role in turning a modernizing-developmentalist regime of improvement into an actual regime of government. And this is apparent, I would argue, in the continuation of extractivism and in the way in which the 20013-2017 PNBV was constructed as well as in some of its contents of the earlier PNBVs.

In addition to auto-ethnography, I will employ Dean's concept of governmental "fields of visibility" (Dean, 1999: 41). "Fields of visibility" are part of a governmentality analysis of state practices that poses the question: what is the field of visibility that characterizes a regime of government? More specifically,

by what kind of light it illuminates and defines certain objects and what shadows and darkness it obscures and hides others. An architectural drawing, a management flow chart, a map, a pie chart, a set of graph tables, and so on, are ways of visualizing fields to be governed. These all make it possible to picture who and what is to be governed, how relations of authority and obedience are constituted in space, how different locales and agents are to be connected with one another, what problems are to be solved and what objectives are to be sought (Ibid.)

Bringing the concepts of reverse auto-ethnography and fields of visibility into my analysis, allows me to ask the question: by what means are these two narratives integrated into a governmental plan like PNBV? Does one of the two narratives obscure the other? And finally, what are the governmental effects of the marriage of the two in terms of problematization, techniques and solutions given to the problems presented in the plan? 
5.10 Sumak Kawsay/Buen Vivir and Developmentalism in the PNBV: 20072010, 2009-2013

To begin with, the history and context in which the PNBV emerges should be pointed out. First of all, the PNBV is the state's most important planning document. It is produced by SENPLADES over periods of every four years and contains the main guidelines for establishing public policy in Ecuador. It could be said that the PNBV emerges as a result of two political processes: from the need by the Correa administration to reinvigorate and specifically to recover its role as "regulator and planning [entity]" (SENPLADES, 2012: 10). The second emerges as a result of the "radical rupture" narrative through which Correa and his political movement won their first election in 2006. Broadly speaking, Correa's radical narrative about breaking with the past is rooted in the irregular and eclectic merging of three political economy theories: decolonial/postcolonial approaches about "civilizational changes" (Espinoza, 2011); an Amartya Sen-inspired capabilities approach (Walsh, 2012); and third, a "light-marxist" approach. This somewhat eclectic combination can be witnessed in the title of the doctrine developed by SENPLADES's former Secretary General, and current Senescyt ${ }^{24}$ Director, Rene Ramirez, "Sumak Kawsay/Buen Vivir socialism or republican biosocialism" (Ramirez, 2010).

Thus, in the context of a post-neoliberal process of re-articulating the state participatory planning was seen as a basic function of a state needing to be recovered. Similarly, the narrative of radical rupture from neoliberalism and past processes of exclusion upon which Correismo's electoral success and state reform

\footnotetext{
${ }^{24}$ Senescyt is the National Secretariat for Superior Education, Science, Technology and Innovation.
} 
were enfolded in the language and symbols of SK and indigenous peoples' resistance. As shown earlier, SK/BV symbols and language permeate the state and its institutions. The PNBV is no exception. The "living well (or good living) in the title of the PNBV is a direct allusion to the principles of SK/BV. In fact, "good living" is an approximate Spanish translation of the Kichwa words Sumak Kawsay/Buen Vivir .

Table 1: PNBV 2009-2013 Objectives

1. Foment equality, social and territorial cohesion in diversity

2. Improve the potentialities and capacities of the citizenry

3. Improve the populations' wellbeing

4. Guarantee the rights of nature and promote a healthy and sustainable environment.

5. Safeguard national sovereignty, peace, and foment Latin American integration and the strategic insertion of the country in the world

6. Guarantee dignified, just and stable employment in all its diverse forms

7. Construct and strengthen public spaces and spaces of public encounter

8. Affirm the national identity, strengthen diverse identities, interculturality and plurinationality

9. Guarantee respect for rights and justice

10. Guarantee respect for access to public and political participation

11. Establish a social, solidary-based and sustainability

12. Construct a democratic State for the Buen Vivir

Source: PNBV, 2009-2013: 11-12

\subsection{An Analysis of the 2009-2013 PNBV}

The 2009-2010 plan begins with its main themes, called "revolutions," which include the following fields: democracy and constitutional change, ethics, the economy and productivity, social (indictors like poverty and inequality), sovereignty, dignity and integration. These revolutions are then followed by twelve objectives. See table 2. The first part of the plan indicates its architecture. The plan 
is composed of three parts: a conceptual part, a definitional part, and regarding the concretion of public policy, an instrumental part. Not unlike what Dean (1999) or Lemke (2007) would have predicted, the governmental plan consists of a discursive aspect, a problematization aspect and a technical aspect.

\section{The Conceptual}

A central theme in the PNBV is the notion of a crisis in development. Reminiscent of the arguments of authors like Arturo Escobar (1995) (also see Rojas, 2001) and Boaventura de Souza Santos (2006) (De Souza Santos is favourably cited in the plan - see, for instance, page 31), the PNBV posits that the "dominant concept of 'development' has entered into a profound crisis, not only because of the colonialist perspective from which it was developed, but because of the poor results that it has generated around the world" (PNBV, 2010: 31). Thus a postcolonial/critical/culturalist vision of development is also presented as a criticism of "modernization theory", Euro-centric conceptions of "linear time" and unidirectional historicity. These critiques are all consonant with SK and indigenous cosmovisions (cf. de la Cadena, 2010). Thus, the central notion of development presented in the plan is fundamentally linked to the work of critical academics and the indigenous principles of SK.

The conceptual part of the plan also evokes Marxist theories as it contains a critique of capitalism, attributing the lack of "development" within certain societies to structural forces within capitalist accumulation and external factors. It is also reminiscent of the work of Amartya Sen in its emphasis on human development, 
development and human freedoms and capabilities (Ibid: 32-42). Other academics' perspectives on development, capitalism, and equality, like those of Martha Nussbaum and Nancy Fraser are discussed in this section of this PNBV - even Kant and Aristotle appear in this section of the plan (see, for example, p. 36). In other words, this section of the PNBV is hardly accessible to a common person. It is full of abstractions, complex concepts and a plethora of intricate (and largely unexplained) arguments. While it may be argued that this is a commonplace issue in development plans, the progressive rendering of political issues technical in the PNBV reveals participatory planning as a governmentalized phenomenon. For example, according to the PNBV, the new mode of accumulation that would overcome the limitations of a primary, exports-based accumulation system is referred to as "endogenous development with linkages to the world system in order to satisfy basic needs" (PNBV 2009-2013, 2010: 94). The new paradigm of production was a highly politicized issue during the Constituent Assembly process of 2007-2008. One of the fundamental demands of indigenous organizations, like CONAIE, was precisely to incorporate into the new productive matrix of the state their knowledges and practices and consider their relationship to the natural environment as a cultural issue, not an economic one. At the early stages of the PNBV some of these issues are mentioned; however, these become largely bypassed in favour of more technical explanations as the document progresses. This new mode of accumulation is presented in Table 2.

This example is not insignificant, for the basic conception of thinking in terms of SK, good living and/or as Cristina Rojas puts it, thinking "other" requires 
forms of accumulation rooted on non-capitalocentric ideas and ontologies (see Rojas, 2009; Escobar, 2010). Similarly, the intercultural paradigm of SK would call for an intercultural questioning of the very notion of accumulation. While one of the serious shortcomings of the SK doctrine and proposals regarding the decolonization of knowledge, including economic knowledge, is the lack of concrete mechanisms to overturn the structures of accumulation short of a Marxist-style or Zapatista-style revolution, it is unclear from the PNBV what makes its strategy of accumulation compatible to or a part of SK or Buen Vivir. The strategy of accumulation is rooted in a hypermodernist notion of development. This type of what I call "modernizing neodevelopmentalism" is characterized by developmentalist strategies of development seen in South Korea.

Thus, it is important to note that despite the call for the practice of "epistemic diversity" and the use of "local knowledges" the conceptual part of the plan is largely a modernist exploration of abstract/rational economic ideas many of which, like the ones shown above about the new model of accumulation, have no direct or evident linkages to a post-accumulation strategy based on local knowledges or intercultural economic forms of thought. While it is the case that the biotechnological addition to the mode of accumulation hopes to take advantage of local (indigenous) knowledges, it is unclear whether the technological modernization and advanced industrialization the PNBV speaks of is any different from capitalist developmentalism (see for instance Johnson, 1982), except for its emphasis on bioproduction. I should stress, nonetheless, one important point: I am not arguing that the accumulation regime proposed in the 2009-2013 PNBV is problematic in itself, 
for that would be part of a different work; what I am attempting to show is how SK narratives are diluted in a developmentalist policy framework that bears little resemblance with the radical ethos of SK.

Table 2. "Phases of the Endogenous Strategy for Satisfying Basic Needs"

\begin{tabular}{|l|l|l|l|}
\hline Phase 1 & Phase 2 & Phase 3 & Phase 4 \\
\hline $\begin{array}{l}\text { Accumulation } \\
\text { for the } \\
\text { transition and } \\
\text { deepening of } \\
\text { redistribution }\end{array}$ & $\begin{array}{l}\text { Distribution of } \\
\text { Accumulation and } \\
\text { Consolidation of } \\
\text { Import Substitutio }\end{array}$ & $\begin{array}{l}\text { Consolidation of } \\
\text { the Export } \\
\text { Substitution and } \\
\text { the distribution in } \\
\text { accumulation }\end{array}$ & $\begin{array}{l}\text { Productive } \\
\text { Reconversion }\end{array}$ \\
\hline $\begin{array}{l}\text { Selective Import } \\
\text { Substitution }\end{array}$ & $\begin{array}{l}\text { Clean Energy } \\
\text { Surplus. } \\
\text { Consolidation of } \\
\text { Domestic } \\
\text { industry and } \\
\text { tourism }\end{array}$ & $\begin{array}{l}\text { Diversification and } \\
\text { substitution of } \\
\text { export, research, } \\
\text { innovation, science } \\
\text { and technology }\end{array}$ & $\begin{array}{l}\text { Tertiary, exporter } \\
\text { of bio knoweldge } \\
\text { and tourism }\end{array}$ \\
\hline $\begin{array}{l}\text { Applied } \\
\text { Technological } \\
\text { Transfer }\end{array}$ & $\begin{array}{l}\text { Technological } \\
\text { research and } \\
\text { development }\end{array}$ & $\begin{array}{l}\text { Technological } \\
\text { innovation }\end{array}$ & Biotechnology \\
\hline
\end{tabular}

Source: PNBV 2009-2013, 2010: 96

Moreover, it is not clear from reading the plan what epistemic diversity would look like in a plan of this nature. It is also not clear how popular knowledge played a role in the conceptual section of the plan or, more importantly, whether and how subaltern knowledges can help (re)define the state as a structure. Judging from the workshops I attended and/or obtained data from about the construction of the 2013-2017 plan (see below), it would appear that the demand-based governmentalized form of participation would prevent any such knowledge to emerge as knowledge-practice from the bottom-up. This is because what used to be political demands become channelled through the "anti-politics machine" (cf. 
Ferguson, 1994) of the state into issues that appear manageable, practical, feasible and, importantly, amenable to technical solutions within the reach of the state. Popular demands appeared filtered as academic knowledges. Finally, in the section on plurinationality and interculturality the plan defines the problematic according to standardized development indicators like poverty, exclusion and discrimination. It spends time emphasizing that the idea of many nations within ought not to mean separatism or internal division and presents the European Union as an emblematic example (p. 45). In sum, it is not clear how or whether it is possible to read this text through an intercultural perspective.

In sum, the conceptual portion of the plan reverts to a type of governmental logic that represents issues as manageable. Clearly states ought to attempt to solve issues, this problem-solving element is a necessary condition for the emergence of the modern state. However, there are issues, as Rancière-influenced analysis would reveal, that do not belong to the real of "solvable" but of the deliberative. Some issues need not be represented as problems to be solved but as tensions to contend with. However inaccessible, the PNBV is filled with the language of SK. Indeed, the language of SK is employed throughout the section of the plan. However, its argumentative structure, the actual content of its critique and deconstruction of development, neoliberalism and capitalism refer back to and employ the "Eurocentric" approach that SK is highly critical of (cf. Leon, 2011). There are, for instance, no references, in the conceptual portion of the plan, to indigenous intellectuals, academics or leaders (PNBV, 2010: 17-46) - no actual application of SK principles in the construction of the conceptual order of the PNBV and, thus, no 
indication of how some of the SK principles could be turned into practices (something that would require direct empirical references to indigenous experiences, not abstract conceptualizations of indigenous forms of being). Instead, the language of SK is diluted into a meta-narrative about development largely rooted on Amartya Sen's and Martha Nussbaum's Human Development approach (HDA) (PNBV, 2013-2017; Sen and Nussbaum, 1993) - an approach which, in the words of Catherine Walsh (2010: 17), contradicts SK principles in various ways:

[H] uman development seems to envelop only further the human condition. On the one hand, it suggests the continued operation in Latin America of the multicultural logic of neo-liberal capitalism and its ability to condition modes of thought and conform to a common sense that legitimates the machines of power, making it increasingly difficult to search for alternatives.

Moreover, Walsh (2010: 16) notes regarding educational policy and the HDA in Ecuador:

The strategic value of liberty and autonomy [basic principles of the HDA approach] can be most clearly observed in Latin America in the present re-forming of education, from primary school to the university. Here education is being transformed into an individual and personal project, a consumer good in which competition between students and among teachers is the motor in the search for 'quality' and 'excellence'. 'Objective' and quantifiable indicators of quality and control, including exams, standards, and accreditation benchmarks, are converting 
educational institutions into enterprises where public space and social responsibility operate under a privatized logic. Social gaps, social injustices, and educational failure are seen as personal and family problems that can be individually overcome. In a world that once valued solidarity, fraternity, reciprocity, and collective community- based relations, individual stamina and initiative are quickly becoming the guiding principle and force.

\subsection{Problematization in Action: Opening Up Spaces of Government in the PNBV}

Following the principles of governmentality established by Dean, I will now look at acts of problematization that enable government to be deployed into areas where it previously did not exist, as well as areas where it already had a presence. The planning structure presented in the PNBV addresses the twelve objectives mentioned above. First, it provides a foundation/justification for intervention; second, a diagnosis; third, policies and directions, and, finally, goals. For my purposes here I will analyze Objective number 3 but (see Table 2). ${ }^{25}$ The reasons for choosing Objective 3 is that it is more encompassing than others and constitutes objectives whose sense or meaning should be determinant of all the others.

\section{Objective 3: Improving the Wellbeing of Populations}

The conceptual foundations for this objective are, much like the ones cited above, based on the notion of human capacities, human happiness, diversity, the

\footnotetext{
${ }^{25}$ Appendix 1 shows the contents and conducts the same analysis for of Objectives 4 and 8, showing identical results.
} 
rights of nature and participation. They are also rooted in a stated critical stance towards neoliberalism and an inclusive view that regards the wellbeing of indigenous nationalities and pueblos and Afroecuadorians as essential to the overall wellbeing of the population (see PNBV, 2010: 189-190).

After providing the conceptual foundation, the process of problematization moves to the actual diagnosis of the problem. It is here where the governmentality concept of "fields of visibility" becomes particularly useful. When comparing the diagnosis and the foundations sections one sees that a number of interesting patterns begin to emerge. First, and perhaps not surprisingly, the use of charts, maps, statistics and tables and other technical devices designed to create a picture of reality are a lot more common than in the conceptual section. Like I said, this is not that surprising. However, when one analyzes the actual content and space that these devices contain and occupy, one realizes that the conceptual and the diagnostics are not congruent. The charts, tables and graphs presented in the diagnostics part of Objective 3, occupy about ten out of 16 total pages. This means that these charts to a large extent measure wellbeing. It also means that a large portion of the tools to achieve wellbeing will have to address the content of the charts, tables and so on. The specific list of charts and tables is provided in Table 3.

The progression showed by the sequences of tables 3,4 and 5 shows, the field of visibility related to quality. As one can see, specific objectives are established as concrete acts of governmental intervention, in a biopolitical sense of improvement. I should note that I am not arguing that health ought not to be part of wellbeing or that there is anything problematic about this inclusion. To the contrary, 
if anything (good) health is, clearly, an indicator of wellbeing. The point being made is about how governmental planning unfolds, from the conceptual to the practical; how acts of problematization entail specific fields of visibility that, as Dean puts it, shed light on certain issues while darkening others (Dean, 1999). The point is not whether or not this takes place, after all, it is inevitable to shed light on some issues while darkening others, the issue is how this takes place and what are its actual and potential effects in a specific socio-political and historical context.

Table 3. List of Charts, Tables and Maps in Objective 3 of the PNBV 2009-2013

\section{Table 7.3.1: Proportion of overcrowded households \\ Table 7.3.2: Main causes of infant mortality \\ Table 7.3.3: Mortality rate by known causes \\ Table 7.3.4: Infant mortality rates (less than a year old babies) and mortality resulting from maternal causes}

Table 7.3.5: Distribution of successful births by mother's age, Ecuador 2003, 2008

Table 7.3.6 Number of cases of main morbidity causes, according to illnesses of obligatory notification

Table 7.3.7 Number and percentages of notified AIDS cases

Table 7.3.8 Rate of incidence of malaria for every hundred-thousand inhabitants

Table 7.3.9 Rate of incidence of tuberculosis for every hundred-thousand inhabitants

Table 7.3.10: Conjugal violence according to type and place of residence

Map 7.3.11: Life expectancy by province

Graph 7.3.12. General mortality rate

Graph 7.3.13. Infant mortality rates

Source: PNBV 2009-2013, 2010: 190-202

While it is clear that all of the issues presented in table 3 are of importance, it is not as evident, what the role of epistemic diversity is and how intercultural thinking determined the tools and mechanism for dealing within those issues. Moreover, it is hardly clarifying how SK/BV informs this set of policies and, particularly, the movement from acts of problematization to techniques of intervention. To illustrate my point in relative terms, it is difficult to see the paradigm that the PNBV is ultimately responding to. What is being argued here is 
that there is no way of deriving or making intelligible, from the policy progression presented above the presence of SK/BV.

Table 4. Policies and Guidelines

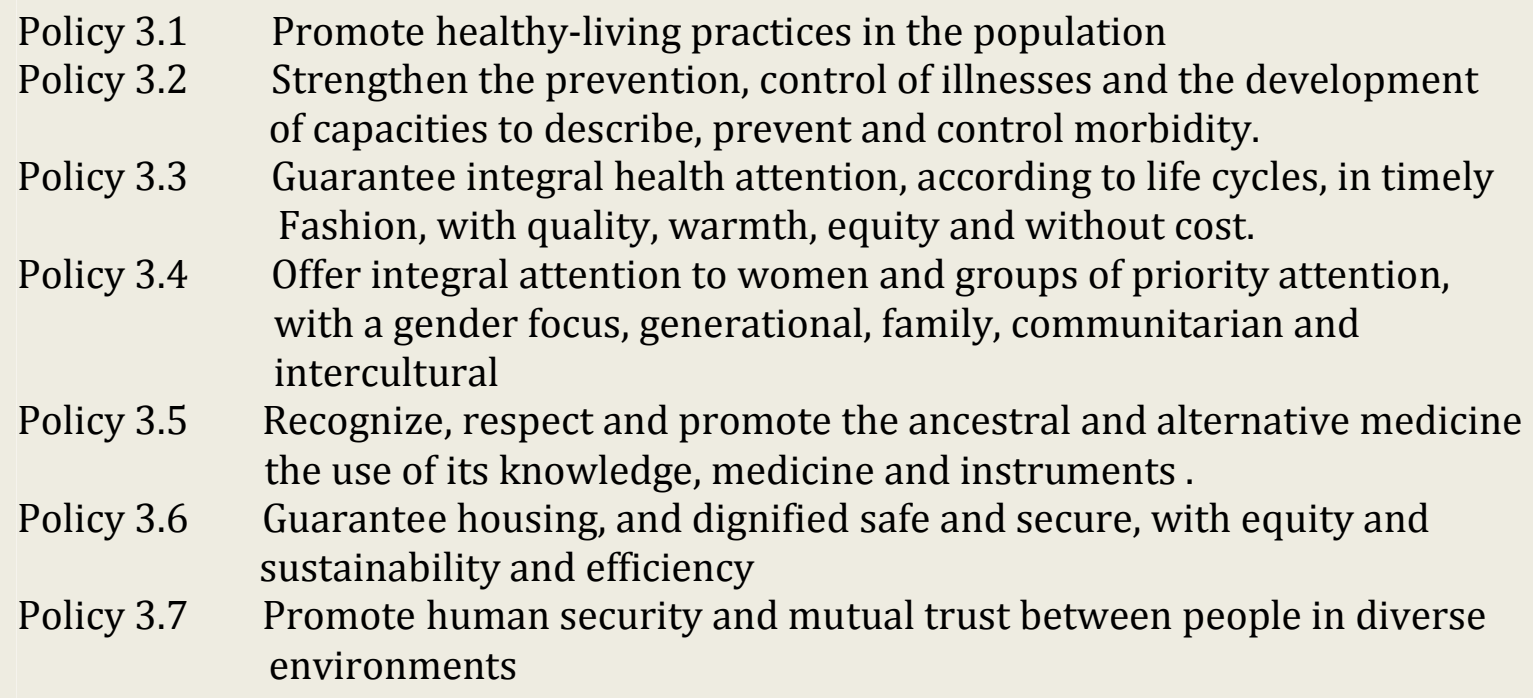

Policy 3.5 Recognize, respect and promote the ancestral and alternative medicine the use of its knowledge, medicine and instruments .

Policy 3.6 Guarantee housing, and dignified safe and secure, with equity and sustainability and efficiency

Policy 3.7 Promote human security and mutual trust between people in diverse environments

Source: PNBV 2009-2013 (2010: 202-205)

Similarly hidden are specific, concrete practices of SK/BV stemming from the lived experiences of communities. Moreover, what is hidden are the specificities regarding the type of changes Ecuadorian society would have to undergo in order to adopt new paradigms of development, like, for example, achieving an antiextractivist economic base, as indigenous organizations like CONAIE (as well as others) suggest. In other words, the only practicable components of the PNBV are by-and-large beyond the realm of politics (and SK/BV) and in the realm of the technical possibilities of the governmental interventions. In short, the PNBV is a plan for experts, even though its ethos as a planning tool is rooted in the idea of popular participation. It is moreover, difficult to see how it is open to political 
challenges in country like Ecuador as it is shielded in the use of technical knowledge, highly abstract language and even largely confusing theoretical base. In synthesis, it can be said that it is not that participation has been replaced by expert knowledge but that participation, as the PNBV makes evident, has become governmentalized.

Table 5. Specific Objectives

3.1.1 Multiply by three the percentage of the population which does physical exercise more than 3.5 hours per week by 2013.

3.1.2 Reduce obesity in schools to $5 \%$ by 2013.

3.2.1 Reduce the incidence of malaria by $40 \%$ by 2013 .

3.2.2 Decrease to 4 the mortality rate of haemorrhagic dengue fever by 2013

3.2.3 Reduce the AIDS mortality rate by $25 \%$ by 2013 .

3.2.4 Reduce the mortality rate of tuberculosis to 2 per 100.000 by 2013.

3.2.5 Reduce the mortality rate derived from diseases caused by the poor quality of water to third by 2013.

3.2.6 Reduce pneumonia or and reduce its mortality rate by $18 \%$ by 2013.

3.3.1 Ensure that public institutions cover 70\% of births by 2013 .

3.3.2 Increase to 7 the performance qualification of public health services by 2013.

3.4.1 Reduce teenage pregnancy by $25 \%$ by 2013 .

3.4.2 Reduce maternal mortality by $35 \%$ by 2013.

3.4.3 Reduce early neonatal mortality by 35\% by 2013.

3.6.1 Reduce the percentage of overcrowded homes by 33\% by 2013.

3.6.2 Grant access to sanitation services to 80\% of homes by 2013.

3.6.3 Decrease to $35 \%$ the percentage of households which rely on physically inadequate housing by 2013.

3.6.4 Decrease to $60 \%$ the percentage of households with qualitative housing deficit by 2013.

3.7.1 Revert the trend of rising criminality, and reach $23 \%$ by 2013 .

3.7.2 Increase to 7 the users' assessments of the quality of the service of the National Police by 2013.

Source: PNBV 2009-2013, 2010: 206; English Version

It should also be noted that issues like mortality rates, the treatment of deadly illnesses, and domestic violence, have all been identified as problems by 
many different forms of government. SK/BV would, undoubtedly, have on its policy roster those issues, but it is in the government of them, specifically in the constitution of techniques and areas of intervention that SK can be made intelligible from other approaches.

The Tables presented above also show ways in which the particular field of visibility developed in the case of "quality of life" relates to the Constitutional mandate of interculturality and inter-epistemic dialogue and how the transition from the conceptual, to policy statements to concrete interventions based on specific objectives, is more akin to the developmental and HDA logics mentioned earlier and less so to the ideals of SK/BV, like interculturality. The government progression displayed in Tables 3, 4 and 5, I would argue, suggests that the continued use of SK language has an important discursive effect: it weakens and potentially neutralizes the radical content of SK and, ultimately, its political usefulness for indigenous and popular struggles. In other words, the continued use of the language of SK has the opposite effect of an auto-ethnography, as Catherine Walsh (2010: 20) puts it:

The crucial question is whether buen vivir is becoming another discursive [rhetoric] tool and co-opted term, functional to the State and its structures and with little significance for real intercultural, interepistemic, and plurinational transformation. Certainly such question and concern are warranted when we take into account government actions in the last months, including the approval of a mining law and the proposal of a water law that clearly contradict the tenets of buen vivir. 
An issue like infant mortality rates is not the exclusive domain of SK/BV and neither can one affirm that its presence in the PNBV signals the governmentalization of participation or reign of experts over popular sectors. Rather, one of the fundamental characteristics of SK/BV is the civilizational challenge it proposes. What the policy structure of the plan is making invisible is precisely the "radical" content of SK/BV. In other words, the content of SK becomes diluted in a series of social concerns that, while legitimate and needed, do not necessarily reflect this particularity about SK/BV. Moreover, the act of making the civilizational challenge invisible is also enabled by the fact that the issues presented in the plan, are hardly opposable. The issues presented would unlikely meet any opposition and are therefore more likely to be accepted as evident expressions of SK/BV. This is a consistent strategy of power in the constitution of the Ecuadorian state: making invisible and/or disciplining the civilizational challenges posed by the content of $\mathrm{SK} / \mathrm{BV}$. As shown in the next chapter in the case of the Indigenous Directorate of Bilingual Education (DINEIB), for example, indigenous people's institutions within the state have been stripped of their political autonomy and given a more moderate angle.

A similar example can be found in the state's response to indigenous opposition to mining and petroleum exploration. According to the developmentalist narrative of the state, petroleum exploration and mining are needed, precisely, to combat the ills brought by poverty, illness, poor education and so on. The developmental narrative presents a false dichotomy between conservation and poverty. According to President Rafael Correa, for example, through the 
exploitation of petroleum in the fields next to park Yasuni Ecuador "ought to overcome poverty, build hospitals, adequate schools, housing, energy (sic), and bring basic public services to each territory [in the country]" (Correa, as cited in El Ciudadano, 2013: http://www.comunicacion.gob.ec/la-explotacion-responsabledel-yasuni-contribuira-a-disminuir-la-pobreza/). Indigenous protests against the government mining laws were met by disciplinary acts involving the use of public force and/or discursive violence (Becker, 2010). Thus, once presented as it is in the PNBV, stripped of its radical content, SK/BV narratives become one with developmentalism. In this sense, the tensions and contradictions within state narratives disappear leading to a highly technocratic document that leaves the very important and crucial confrontation between these two narratives unattended. In this way, the highly political sets of concepts linked to SK, like interculturality, are largely stripped of their political character.

According to Pratt (1992), auto-ethnography involves "a selective collaboration with and appropriation of the idioms of the metropolis or the conqueror. These are merged or infiltrated to varying degrees with Indigenous idioms to create self-representations intended to intervene in metropolitan modes of understanding the use by subaltern groups of the languages of dominant groups entails" (Pratt, 1992: 88). By contrast what I call "reverse auto-ethnography" entails precisely the opposite: The continued use of indigenous (subaltern) languages and symbols by dominant groups, including the state, which are merged or infiltrated with hegemonic discourses to intervene in indigenous modes of understanding, and most importantly in indigenous political action. 
Again, it must be remembered that SK was a radical discourse developed largely by indigenous and subaltern intellectuals to represent in radical ways (from the perspective of the dominant cultures and structures, including the State) the need for a civilizational change. This means that the exercise of what I term reverse auto-ethnography empties SK languages of their radical content leading to a depoliticization of the concept, of the language once used to construct a radical indigenous project and movement. As shown in the previous chapter SK and/or Buen Vivir are a pervasive element in state narratives and much of its radical/progressive content attenuated, if not completely eliminated, by the very pervasiveness of its use. SK language, particularly its Spanish translation, "Buen Vivir," has been used, as shown earlier, in a plethora of programs, public works and other governmental projects that are seemingly more representative of developmentalism than the radicalization of society or a civilization challenge. Just to mention a few examples, SK/BV has been used in landscaping projects (see Image 1 above), in tourism and gastronomic fairs (see for example Ministry of Tourism, 2013: http://www.turismo.gob.ec/mintur-participo-en-feria-turistica-artesanal-ygastronomica/) and even by the Ministry of Defense in national security operations (see for example, Ministry of Defense, 2013: http://www.defensa.gob.ec/ff-aacomprometidas-con-la-seguridad-del-estado/).

It is also crucial to point out the importance that the ethnic-cultural discourse has played in the amalgamation and cohesion of the indigenous movement and organizations and its participation in political mobilizations (both electoral and nonelectoral ones). As Lalander and Ospina note, this has been the most important 
"gluing" aspect of indigenous organizations (Lalander and Opsina, 2012). And as the political program of CONAIE shows, the most important political demands have been developed around the concepts of plurinationality and interculturality (CONAIE, 2013). In other words, the importance of preserving the discursive and radical content of the intercultural and plurinational narratives is also important for the cohesiveness and organizational strength of indigenous peoples. Thus, the deradicalization of the term and its incorporation, through reverse-autoethnography, into the state discourses about development should be expected to have weakening effects in the organizational strength of CONAIE. This finding is confirmed, albeit via a different theoretical route, by the research of Lalander and Ospina. These authors state that:

It is very important to emphasize the strategic and symbolic value of the application of indigenous symbols - SK and Buen Vivir - that the government of Correa-Pais has incorporated and institutionalized in its policies and principles, neutralizing opposing indigenous groups, thereby seeking legitimacy for its developmentalist policies (Lalander and Ospina, 2012: 31; emphasis added).

In sum, the combination of a highly "academicized" narrative shielding the PNBV from some levels of political critique, the specificities of the fields of vision in the development of governmental interventions, like those contained in the PNBV, as well as the process of reverse auto-ethnography, produce a depoliticizing strategy aimed at enhancing and strengthening the role of the state at the expense of social organization and social movements, particularly indigenous ones, like 
CONAIE. At the same time, however, one of the most important stated objectives of Correismo and the state itself through its Constitution is "to guarantee access to public and political participation" (PNBV, 2010: 315). This point is particularly important for my purposes here because one of the central hypotheses of my work is that participation is being governmentalized and is central to the general depoliticizing thrust of the new state. The following section tackles this issue through an analysis of the construction of a regime of "participatory" citizenship from the perspective of the state.

\section{Conclusion}

Following some of the interpretative principles laid out by Foucault's studies of government, this chapter looked at the work of SENPLADES and its relationship to the formation of governmental regimes, and therefore, state construction. Some of the important analytical relationships laid out in the chapter were the relationship between knowledge and government and the need to look at knowledge practices in order to understand how a state-construction process unfolds as it intervenes in society. Processes of governmentalization of the state relate to practices such as problematization, rendering technical and the utilization of techniques like mapping in the creation of populations in particular ways.

By following this logic of analysis, one of the central objectives of the chapter was to highlight and reveal how practices of government make invisible certain populations and how important forms of representation are for the practices of government and its relationship to specific populations. Once again the chapter 
paid particular attention to the relationship between government and participation and indigenous populations. One of the central contentions of the chapter was that the work of SENPLADES is intimately related to the practice of rendering technical (Li, 2007). Like Foucault and governmentality studies scholars "predicted" in processes of re-articulating the state in modernity one should expect to see the emergence of SENPLADES-like organizations in charge of creating state practices and establishing part of the knowledge production-base for the state to emerge in places where it had previously been absent. The question, following some of the methodological precepts of a governmentality studies approach is not only why but how such knowledge-based practices are developed and how their discursive practices reveal areas of intervention in particular ways (Sean, 1999; Jessop, 2007). To complement the content of this chapter, the following chapter looks in more concrete terms at certain institutional arrangements regarding participation and the construction of the 2013-2017 PNBV. One of the central preoccupations of the next chapter is to evaluate state-society relations in concrete terms by following the logic of state formation both at the levels of institutions and state planning through the construction of the PNBV. 


\section{CHAPTER SIX}

\section{THE CONSTRUCTION AND GOVERNMENT OF PARTICIPATORY CITIZENSHIP}

\subsection{Introduction}

This chapter is concerned with the construction of the PNBV. In the grand scheme of this work's argument this chapter presents an analysis of state-society relations at the meson- and micro-levels. While previous chapters presented a macro-level analysis of how the state reconfigures society as it is itself being rearticulated, here I present an analysis of governmental practices at the level of concrete relations between SENPLADES and participants in the PNBV workshops. This chapter's main contribution to the overall argument of this work is that the process of state development in Ecuador is characterized by a depoliticizing thrust that is not necessarily the result of a utilitarian, conscious decision by state officials. It is the indirect, de-centered result of the unfolding of governmental techniques and their constitutive mentalities.

\subsection{Participation, Citizenship and the State}

One of the main arguments of this work is that a state, like the Ecuadorian one, develops its strength and consolidates itself through the expansion of government. But of course, government cannot expand endlessly, nor does the expansion of government necessarily entail the consolidation of a state project. A successful governmental project entails, among other things, the production of openings and closings that administer spaces within the state for non-state actors to 
penetrate. This form of governmentality includes specific institutional arrangements to administer the degree to which people are able to participate in policy development processes and generally in the construction of the state. Following a governmentality-inspired approach, it becomes important to inquire about the specific ways in which these spaces (through openings and closings) are designed, administered and distributed.

It is the balance between openings and closings that should, theoretically, create the conditions of possibility for a stable process of rule. Too many closings, for example, could produce resistance to government and, thus, its inability (without recourse to force or the breakdown of democracy) to expand its reach into society. Openings are important aspects of government because they operate upon the conduct of groups and individuals without the need for direct control, prohibition, coercion and/or repression. Moreover, openings work as governmental tools in the sense that openings seek to create a sense of voluntary compliance from populations based on the notion of what-is-good-for-oneself (improvement).

The notion of openings and closings stems from one of Foucault's central ideas for studying government and the state, namely, that any analysis of power relations, state forms and governmentalities cannot be reduced to juridical forms. It should be clear from the discussion thus far that the way government is being constructed, in practice, is not always compatible with some of the principles of SK. Thus, following Foucault's analyses and the logic of reverse auto-ethnography introduced earlier (cf. Pratt, 1995; Conway, forthcoming) I look at the narrative of SK in instances like the Organic Law of Citizens' Participation (OLCP), as an 
important element in the Constitution an actual regime of government through participation and citizenship - a regime that may or may not, in practice, reflect the principles of SK envisioned by social actors during the drafting of the 2008 Constitution.

\subsection{Institutional Analysis of Participation: Openings and Closings as a form of Governmentality}

The actual construction of participation from the perspective of the state and, therefore, of participatory citizenship through the state is also permeated by the confrontation of the narratives of modernizing-developmentalism and $S K / B V$. Article 1 of the OLCP, for example, states its ontological base, using the language of SK, as one being composed not only by citizens at large but "collectives, communes, communities, indigenous peoples and indigenous nationalities, Afroecuadorian and montubio [coastal peasants], and other forms of legal organizations" (OLCP, 2010: Article 1); similarly the OLCP recognizes the "protagonist" nature in decisionmaking processes of these groups and their "autonomous collective organization." (Ley Organica de Participacion Ciudadana, 2010: Article I). According to both the Constitution and the OLCP, Ecuador's citizenship regime can be defined as "the democratization of the relationship between the citizenry and the state [and] ... equality of opportunity for the participation [of the above mentioned groups] in the various spaces and instances that have been created for the interlocution between society and State..." (OLCP, 2010: Article 3).

Ecuador's formal-legal institutional apparatus of participation and participatory citizenship is divided into three basic pillars: first, public hearings, 
assemblies and councils; second, overseeing bodies and previous consultation; and third, the Empty Chair (see below) mechanism (OLCP, 2010: Articles 72-101). In addition, the state created the Consejo de Participacion Ciudadana y Control Social (Council for Citizens' Participation and Social Control) (CPCCS), which is in charge of articulating and organizing these participatory instances (Constitution of Ecuador, 2008: Article 100; OLCP, 2010: Articles 90, 94). These mechanisms, in addition to the CPCCS, act to encourage decision-making processes within the state. The institutional design of participation was, in fact, built through a series of openings that in principle allow non-state actors to penetrate the state and its decisionmaking processes. This is undoubtedly a positive contribution to the development of the participatory form of citizenship established by the Constitution. However, there are a few aspects about the distribution of these openings that are worth mentioning. Below I address some of the particularities of the institutional apparatus of participation, beginning with the CPCCS.

The CPCCS is not an elected body and neither is it a political entity where state and non-state actors can engage in debate. However, it is an institution designed to manage participation within the state - and to a certain degree outside it. The CPCCS's role is, in effect, to manage participatory openings within the state. Consequently, it is worth asking about the structure of the CPCCS and how it manages participatory openings. The CPCCS is a council whose members are selected through a "meritocratic," point-based system that is conceived and developed within the state apparatus itself. Its members come from civil society and need not have a political affiliation, or belong to any social group (see CPCCS, 
2013: http://www.cpccs.gob.ec/docs/lotaip/pdf/2010/Reglamento - Organico - por - procesos-CPCCS.pdf). The first opening into the state, therefore, is managed through a meritocratic process that emphasizes professional credentials and talent (exams were used to test the knowledge of candidates). This opening, it should be noted, is quite congruent with the Weberian notion of modernization discussed in an earlier chapter.

This managerial/meritocratic mentality of government, has important implications for citizenship and the (de)politicization of society as a stateconstruction strategy; but in addition to that, the notion of efficiency and meritocracy is significant as a form of government: a form of assigning, limiting and distributing spaces of participation within the state. The claim is that at the center of the CPCCS's governmental credentials lies the question of the technical knowledge and the non-political positioning of its members. This means that, presumably, the administration of participatory processes will be conducted in nonpolitical terms according to the sound judgments of the CPCCS technocrats. But what is the relationship between the technical character given to participation and the technocratic character of the Council? I would suggest that once participation is defined as belonging to the domain of the technical, it becomes subject to subtle techniques of control and conduct-shaping strategies that are rooted on the free and willing participation of individuals.

Thus, it can be said that in this particular instance the state-strategy with respect to the institutionalization of participation is to see participation immersed and subjugated to notions of professional merit, individual talent and a technocratic 
sense of meritocracy. This is not an isolated issue but, rather, a strategy of state construction rooted in Weberian principles of bureaucratic development and modernizing principles akin to modernization theories of the state (Evans, 1995; Scott, 2005). I should note that I am not criticizing modernizing the state according to notions of efficiency (although there are various criticisms that can be made of it), I am pointing out that participation is, in important ways, constructed by the state through managerial techniques (cf. Cooke, 2004). Governing participation through this mentality entails that aspects of participation are de-politicized and rendered technical (Li, 2007b) from the start, which is of course, antithetical to the principles of participation as an eminently political issue and the principles of participation established in the Constitution (cf. Cooke and Kothari, 2001).

In a somewhat distinct way, the Empty Chair mechanism also constitutes a form of government through openings. In contrast to the Council's technocratic approach, the Empty Chair allows political forms of participation but in a (very) limited sense. Specifically, it is applied in local government sessions where an "empty chair" is assigned to one member of civil society, or, more generally, to any citizen concerned with the issue being treated in local government sessions. The Empty Chair is applicable in local governments (called, in Ecuador, "Autonomous Decentralized Governments") sessions. Political participation is made effective by giving its occupant voting powers during local government sessions (OLCP, Article 91). In principle, thus, the empty chair mechanism is the most direct mechanism of participation as it is the only mechanism that allows for citizens to directly participate in public policy debates inside the state. 
The governmental reason behind the Empty Chair is more akin to the admiration and regulation of groups through the provision of limited spaces to nonstate actors to directly participate in the act of government. Participation is governed by allowing relatively open access to the process of government but at the same time reducing accessibility to interested groups by allowing only one Empty Chair to be filled by a non-state actor. However, and as I will show with the example of the PNBV in this Chapter and with the case of education in Chapter Four, limited access to the state is not so much a question of numbers but a question of management of populations: I would like to suggest, that one of the ways in which participation is governed is by encouraging a fragmented population to participate (one member only) while discouraging a cohesive, organized political society to engage in decision-making processes (groups participating as organized, collective entities); it is governed also by opening participation but restricting its scope.

Finally, I would like to address the issue of assemblies, councils and previous consultation. It would appear that the presence of these formal institutional arrangements undermines my hypotheses about popular fragmentation by showing that participatory citizenship is also encouraged among organized groups. To respond to this possible challenge, I would like to briefly mention two issues: first, the role of the CPCCS in their organization and sanctioning of participation; and second, the non-accessibility to actual state structures of these expressions of participation. Put differently, the essentially political nature of assemblies, councils and so on, is managed through closings. This means that entry to the state is, in principle, organized in such a way as to allow fragmented populations (individuals 
and technocrats) in and leave organized political entities, such as trade unions, indigenous organizations, women's organizations and so on, out.

To summarize the points made here, the institutional governmentality of participation though the CPCCS, the Empty Chair and so on, could be said to be organized through a principle of openings and closings. The overall mentality of government does not outright prohibit political activism, or popular organization, but through a balance of openings and closings, discourages it. The second issue of importance mentioned here is accessibility to the state. Popular assemblies and councils are, like I said before, are part of the participatory structure of the Organic Law of Citizens' Participation (the basic law regulating participation in Ecuador) but are not allowed formal entry into the state apparatus. As mentioned, the nonbinding character of their resolutions (OLCP, 2010: Articles 90-100) restricts their participation to the area of debate (if any takes place) outside the boundaries of the state but at the same time managed by the state through the interventions of the CPCCS. Similarly, previous consultation is not binding, not even for indigenous peoples' communities (contradicting Article 169 of the World Labour Organization's declaration on indigenous peoples of which Ecuador is a signatory).

The result of state action in terms of citizenship construction can be further exemplified by the fact that since 2008 the government has only had a handful of significant sets of negotiations with the major indigenous organization, CONAIE and has preferred, instead, to appeal to a strategy of supporting regional organizations, like the Federacion provincial de Centros Shuar (Provincial Federation of Shuar Centres) (FISCH). The FISCH represents only a small proportion of indigenous 
populations and yet its relationship with the state (which amounts to the signing of a statement of Intent for cooperation) is portrayed as an effort to support indigenous organizations. The support for FICSH can be framed as a strategy to divide the indigenous movement that, as Lalander and Ospina (2012) note, started not with Correa but with Lucio Gutierrez (President of Ecuador between 2003 and 2005).

Moreover, and beyond the fragmentation of CONAIE there is a governmental effect at work in the government's support to organizations like FICSH. It is that the most significant medium of encounter between indigenous peoples and the state has taken place in controlled, micro-spaces, not major forums of deliberation and encounter (i.e. political spaces). As I will show with a case study of the development workshops of the PNBV the government of participation is in part rooted in the distribution of spaces: restricting participation to small spaces and in limited numbers. As discussed below, these small spaces are well suited to forms of micromanagement and micro-techniques of government - and power - reminiscent of those analyzed by James Ferguson in his seminal work the "Anti-politics Machine" (Ferguson, 1994).

\subsection{Participation, Citizenship and Populations}

Before I analyze the PNBV workshops, I should bring back into the analysis the issue of populations - populations defined as the accumulation of individuals. In particular, I would like to highlight the empirical and theoretical links between the "discovery" of populations and the individualizing-depoliticizing sense of citizenship 
and participation mentioned above. Although I will analyze this point in more detail in the section on plebiscitary democracy (cf. Conaghan and De la Torre, 2008) later in this chapter, for now I would like to draw attention to some of the basic mechanisms that link participation, citizenship and populations. From a theoretical stance, populations have a direct relationship to a non-politicized view of society as "the notion of population begins to give a positive shape to the non-political field that is external to government" (Dean, 1999: 131). The division between what is political and what is "non-political" is essential to limit interventions: that which is non-political is the domain of society, while politics is the domain of government and the state. In a classic governmentality formulation, one can say that the development of a non-political sphere through a population makes "government at a distance" (Rose and Miller 1992) a discursive possibility.

The second link between populations and a depoliticizing sense of citizenship has to do with the application of specialized knowledge as a technique of government. The Constitution of Ecuador defines citizenship and participation partly in relationship to epistemic diversity and interculturality. This entails that government is a relational activity rooted in multiple knowledges and in the notion that communities themselves know what's good for them. A population, like that, in the abstract, is amenable to the application of expert-knowledge because of the regularities that they present. Populations are ontologically constituted through knowledge practices in the form of statistical constructions (through censuses, for example), diagnosis of development undertaken by experts (economists, health consultants etc.) rates of development and so on. This does not mean, however, that 
other forms of conceiving social groups like ethnic groups are not amenable to management through expert knowledge. The point being made is that large numbers present the type of regularities that have to be studies through statistics and thus technical knowledge. As mentioned in Chapter Two and earlier in this chapter, the diagnosis is an act of problematization that is accompanied by techniques of improvement. Thus, if a diagnosis of a population is established through expert knowledge, so will the tools and techniques of improvement and intervention that will be used to tackle its problems. This is depoliticizing because technical knowledge, by definition is a-political - it knows better.

Third, government through populations can be depoliticizing in the sense that, once constituted as objects of administration, management and government, populations become part of a hegemonic project of improvement and/or development and also of exclusion (Guerrero, 2010). Populations become objects of administration in large numbers. This entails the construction of a hegemonic project around "majorities." This is a form of administration rooted in the statistical construction of regularities: increases or decreases in poverty rates, rates of access to resources, access to education and so on (cf. Rose, 1998; Gordon, 1991). Once administered according to those terms diversity is lost: the object of government becomes the manipulation of statistical information and not the development of a more complex democratic system of participation involving minorities and "irregularities." A statement made by President Correa could perhaps better illustrate my argument. In an address regarding minority rights, Correa stated that for the majority of the population issues like gay marriage, or gender identities are 
simply not priorities and that the real priorities, lie in what's better for the greater population. The implication of Correa's intervention was not that gay rights, or gender issues are unimportant but that the overall development of the population must take precedence (Burbano de Lara, 2013: http://www.hoy.com.ec/noticiasecuador/el-conservadorismo-del-presidente-583336.html)

In synthesis, the relationship between populations and an individualizing sense of citizenship and participation is that freedom, liberties, rights and duties are "applied" at the level of the individual. Populations are the objects of improvement and individuals are, in practice, the subjects of rights, freedoms and duties. In practice, what this amounts to is that participation and politics is reduced to electoral and plebiscitary processes which in turn converts elections and plebiscites into a technique of government, or more specifically, a technique of control of populations. It should be pointed out that, by contrast, the type of citizenship sought by indigenous populations and other popular progressive sectors, as Debora Yashar (1999) shows, is rooted in a politicized sense of citizenship that regards individuals and communities as subjects of rights; it is a view that does not allow for a top-down, expert-knowledge based system of development but an intercultural one based on intercultural political dialogue. This objective is embedded and articulated in the SK language of the Constitution, the OLCP and the PNBV.

There is an additional institutional feature that needs to be addressed: the preponderant role that the doctrine of "human development" (HD) plays in the different PNVBs (2007-2010, 2010-2013, 2013-2017). Understanding the importance of HD, I would like to argue, is also relevant for understanding the 
construction of participatory citizenship as a question of individual rights and choices. The concepts of individual choices and rights are central to the HD approach. HD regards the individual as the basic and most fundamental ontological repository of freedoms, autonomy and capabilities. This entails that,

Social gaps, social injustices ... are seen as personal and family problems that can be individually overcome. In a world that once valued solidarity, fraternity, reciprocity, and collective community- based relations, individual stamina and initiative are quickly becoming the guiding principle and force (Walsh, 2010: 14)

Considering this, two important theoretical differences between the individual-rights approach upheld by HD and the collective-rights approach upheld by indigenous peoples and SK/BV emerge. The first is the obvious fact that HD does not prioritize in its conceptual structure the issue of participatory citizenship as a collective exercise, but as an individual one. Participatory citizenship can be easily reducible, from this perspective, to a question of individual empowerment (through education, better healthcare and so on), the protection of rights, the presence of procedural forms of democracy (i.e. the presence of free, fair and regular lections) and improvements in the socio-economic conditions of individuals and families (see Chandler, 2011). The second aspect is the strategic (power) role that the state plays in potentializing individual capabilities/capacitates. The state stands as a strong figure that empowers individuals while individuals stand, prior to the fulfillment of their 'capacities,' 'autonomy,' and potentialities as a relatively weak and dependent figures against the state. It can be argued then, that the active participation of social 
forces (as a series of organized groups) in the constitution of public policies and public discourses is relatively inconsequential for the fulfillment of individual capacities, autonomy and freedoms. This means that the notion of an organized civil/political society capable of standing as a force for change alongside and/or at times despite the state is simply absent (or unimportant).

In the next section I analyze, in depth, the case and construction of the PNBV. I look at some of the contents of the 2009-2013 plan and analyze it in the wider context of the revival of the state since 2007. I will also present a detailed analysis of research conducted during the development of the 2013-2017 plan.

\section{THE CONSTRUCTION OF THE 2013-2017 PNBV: A CASE STUDY OF THE 2013-2017 PNBV WORKSHOPS}

The PNBV is the final product of a long process of participatory planning and has as its main objective to guide the design, development and application of public policy in Ecuador. Thus far there have been three PNBVs, the 2007-2009, 2009-2013, and the newest, the 2013-2017 PNBV. Moreover, the PNBV is not only the central and most important government planning document but it represents, in theory, a cornerstone of the new participatory democracy model enacted by the Constitution. The PNBV workshops are the vehicle for turning the PNBV into a participatory planning process. The workshops are participation. Studying the workshops is, therefore, fundamental in evaluating and understanding the role of participation in the construction of the PNBV and the relationship between participation and government and state formation. 
In this section I contend that participation and participatory planning in the particular form practiced in the PNBV workshops are governmental techniques that bring about forms of control that go beyond repression and coercion. Participation in the PNBV workshops adopts what I call a "governmentalized" form rooted in the active participation of technical methodologies that strip participation of its more radical contents and synthesize it in a series of practical demands. The governmentalization of participation is not necessarily, as far as my research indicates, however, part of a grand power design by the state to oppress participants. As I show below, the workshops and governmental agents organizing and running them were seemingly committed to fomenting participation. The governmentalization of participation comes through the exercise of techniques and participatory methodologies that conceive participation as a technical, not a political act. Hence, the objective of participatory planning in Ecuador is not to re-politicize society with the aim of bringing about a bottom-up approach to government and state formation, but to make participation a manageable activity through specific governmental techniques. In this sense, PNBV workshops confirm one of the central hypotheses of this work, namely, that the post-2008 process of state (re)articulation can be characterized in terms of the partial governmentalization of the state.

\subsection{Constructing Participation: The Micromanagement of Populations in the Plan Nacional del Buen Vivir}

The PNBV's stated methodology is essentially rooted in participation. It is, nominally anyway, the concrete result of what the government calls participatory planning. The process of PNBV construction is led by SENPLADES and two 
important and correlated ends largely define it: first, to overcome and recuperate the planning capacity of the state (seen as essential to the construction of a postneoliberal state) and the active participation of the citizenry in the process of state planning (SENPLADES, 2013). There is, therefore, a stated linkage between State development, participation and citizenship. In sum, the PNBV is the state's most emblematic symbol of a new state rooted in and defined through participation.

As argued at the beginning of this work, part of my overall argument is that the state is not a monolithic coherent being that always functions in unison. In this sense, the PNBV itself and, of course, the work of SENPLADES and its técnicos (experts, technicians) (as they are called in Ecuador's bureaucratic jargon) can be seen as a genuine expression/effort to reconstruct the state through participation. However, one of the implications of my argument is that government and control can be seen as an accumulation of strategies, techniques, discourses and regimes of practices within specified governmental fields. The power of the state and its functional arm, government, cannot be reduced to the good intentions of one agency and its technocrats. The construction of government is, in part, a mentality (a regime of truth) under which agencies and technocrats operate. Thus, the overall construction of government and the exercise of power is a multifarious and complex interaction between actions, mentalities and discourses.

In view of this theoretical consideration, I argue that the development of the PNBV responds to the governmentalization of participation and that the governmentalization of participation is fundamentally rooted in the separation between a political sphere where the state is the legitimate actor and a non-political 
one that is the 'natural' domain of a population/society. Moreover, I posit that the PNBV workshops represent a way to micromanage society through micro techniques of power and technologies of government (Jessop, 2007; Gordon, 2006; Kerr, 1999). In this sense the development workshops of the PNBV represent another piece and a larger logic of control exercised through the social body itself. Part of my thesis in this section is that the PNBV was in part constructed through what could be called "techniques of absences" (Canter, 2012) that would preclude the development of an ideal sense of a Habermasian deliberative democracy or ideal speech situations (Habermas, 1984). The power implication in the workshops was, I argue, well defined according to a functional and governmental hierarchy even though the stated objective of the workshops was democratic dialogue and to hear the people through their own voices.

The main techniques of the central government in relation to the development plan are quite similar to how NGOs have employed techniques in Ecuador and elsewhere (Ferguson, 1994; Sending and Neumann 2006; Jaeger 2007, Ospina, 2009). Participation has become an interesting case for governmentality because it often loses its political purpose. The rendering-technical, the depoliticization and the technocratization (cf. Li, 2007a, b) of participation have become predominant aspects of the way some NGOs (specifically, non activist NGOs) promote and organize participation (Ospina et al, 2009). One of the central processes of "participatory" citizenship can be found in the creation of the PNBV. Officially, it is "the instrument to articulate public policy and public management and public investment" (SENPLADES, 2013). The PNBV promotes a strategic view of 
government through planning as stated in Article 280 of the Ecuadorian Constitution (Constitution of Ecuador, 2008: Art. 280).

As mentioned earlier in this chapter, the PNBV is, indeed, an expression of a form of control of populations: the PNBV establishes priorities, areas of investment, hierarchies of needs, and a variety of "adequate" techniques to tackle those needs, but it does so through the active (and free) participation of the population. This participation, I would argue, is significant not because of the impact it has on actual policymaking, but because of its governmentality effect. My argument in this respect is not that the PNBV is designed to control people. Instead, what I am trying do is to show the ways in which it does and linking those forms of control to a larger mentality of government that could be defined, much in the same way Ferguson did in reference to the aid industry in Lesotho, as an anti-politics machine.

What I find more significant (and useful) is how certain issues (and not others) fall under the governmental gaze and how those issues flow through the governmental machinery to become public policy. I am, furthermore, highlighting how much/little politics are involved in participatory engagements and in the development of the PNBV, considering that politics is an essential component of participatory citizenship. Below I present an analysis based on research conducted in 2011 and 2012 during various participatory workshops organized by the state through SENPLADES.

The 2013-2017 PNBV Workshops: Methodological Approach and Coverage

Between 2011 and 2012, I conducted primary research in a SENPLADES's 
organized series of participatory planning workshops whose objective was to contribute to the development of the 2013-2017 PNBV. The PNBV is, according to SENPLADES constructed through seven participatory methodologies from meetings, consultations, workshops, seminars and radio programs (PNBV, 2013-2017: 37). There is little specific information in the three different PBNVs (2007-2009, 20102013, 2013-2017) about the methodological tools used in these governmental spaces (the participatory processes to construct the PNBV). This is one of the factors that prompted my research about the micro-mechanisms, and participatory techniques used to construct such plans. According to SENPLADES, as Table 4 shows, there are eight different participatory spaces involved, in varying degrees, in the construction of the 2013-2017 PNBV. Each of

I participated in what SENPLADES calls "Participatory Forecasting Workshops at the Zone [sic] Level (PNBV 2013-2017, English Summary: 29); the total number of participants at these workshops according to SENPLADES was 240 (Ibid.) and their objective was "to identify key problems for a regional and national vision in the long term" (SENPLADES, PNBV 2013-2017: 37). The reason for selecting this particular type of workshop was that, according to the information I obtained from SENPLADES, its discussions would serve as guidelines for the construction of long-term policy objectives and actions (Anonymous Interview, Quito, June $10^{\text {th }}, 2012$; Anonymous Interview, Quito, August $\left.15^{\text {th }}, 2012\right)$. Thus, given the theoretical and empirical objectives of my work, particularly my interest in the relationship between politics and government, this particular participatory instance was the most pertinent choice. 
Table 4. Participatory Spaces for the Construction of the PNBV

\section{Type of Participatory Spaces and Number of Participants}

1. Dialogues for Good Living (5160 participants).

2. Workshops, thematic and focal groups

(1071 participants).

3.0versight mechanisms and observatories

(605 participants).

4. Participatory forecasting workshops at the zonal level (240 participants).

5. Meetings with delegates from national social organizations, sectorial councils and local assemblies (276 participants).

6. International seminar (780 participants).

7. Radio marathons and virtual meetings

(100 participants).

Source: SENPLADES, PNBV 2013-2017, English Summary, 2014: 29

The overall participatory structure set up by SENPLADES is composed of the local, the regional (the "Zone" level) and the national levels (PNBV, 2013-2017: 37) (Anonymous Interview, Quito, June 10 $0^{\text {th }}, 2013$ ). The distribution of populations for the workshops was organized according to eight geographical, cross-provincial regions, created by SENPLADES. These are shown in Map 3.

Participants at the first level included private individuals as well as representatives of local grass-roots organizations; at the second level, participants were delegates from the first round of discussions (although as I indicate below, this 
was a rather disorganized process and not all of the participants had either been to the first round of discussions or been 'officially' selected as community/organization representatives); the third level was conducted through national representatives from all of the regions (see Map 3.). And finally, the National Assembly, which is more symbolic than anything (given that the contents of the plan were already processes) is where all representatives meet with highranking state authorities, and it is here that the PNBV process finally concludes.

Information from one level to the next travelled through documents brought in by SENPLADES. Even though the documentation provided a summary of the previous round of discussion, participants, in what I call "political moments" rarely started, as SENPLADES' officials appeared to have hoped, from where those conversations had left off. Instead participants' interventions at the dialogue tables, but also at plenary sessions, usually veered off into broader, more political issues like structural injustices, racism, marginalization, corruption, land reform and/or lack of participation in state policy-making, but as I show below, the shift from these "political moments" to their de-politicized versions takes place when political stances are turned into concrete demands, mainly material, made to the state and subsequently into "manageable" demands that can be easily processes and summarized by both participants and SENPLADES's officials.

Before continuing it would be worth stressing a few important conceptual distinctions regarding the question of what constitutes a "political" demand and what does not. As mentioned in Chapter Three, historically, much of the demands by indigenous peoples and/or other marginalized groups have been demands rooted 
on material needs: roads, schools, employment, financial support for agricultural producer, etc. What can be concluded from the discussion in Chapter Three is that material-based demands can also be political. Chapter Three also showed an important transition, particularly among indigenous peoples led by CONAIE, to what could be referred to as an "identity-based" set of demands placed on the state. Partly this transition obeys a logic of struggle that seeks to disrupt traditional orders and power structures - an eminently political move. Following this discussion as well as that found Chapter Two regarding what constitutes politics, I define "politicized" demands as those demands containing elements that seek to disrupt established orders reproduced by the state. Political demands can also be understood as those that expose a series of tensions, conflict, disagreements or critical encounters (see the discussion on Chantale Mouffe's view on politics in Chapter Two) between political contenders. In this sense purely material demands that are not accompanied by a disruptive potential on the one hand, or that make evident, or seek to make evident a series of tensions or conflicts (cultural, political, social or economic) are not understood, as far as my arguments here go, as political. That is not to say that if a community's demands are expressed as material demands, they are not rooted on a politicized stance; what I argue is that if a demand is reduced to, say a road, and nothing else, there is little to link it to a sense of disruption or a latent conflict. Put differently, if the relationship between the state and indigenous movements or other social movements is based on purely material demands, without an intelligible field of disruption or tension, it could be argued that that relationship is largely de-politicized. 
I attended and/or obtained information from about fifteen different workshops. The Workshops are organized in two different stages and I researched the second stage. The first stage of the plan is where community members at the local level participate in the embryonic stages of the plan. This is a lengthy process consisting of many local-level meetings that constitute, according to what a highlevel SENPLADES organizer told me, a somewhat "diluted" process without many concrete results insofar as defining concrete state policies is concerned. In theory it is here that regional representatives are chosen and the first stages of participation are carried out; it is also during the first stage that PNBV organizers from SENPLADES are provided with a basic list of priorities, themes and issues to be discussed later during the second stage of the workshops.

The second stage of participatory workshops is more regional in scope and is defined as the previous stage prior to the main PNBV General Assembly. This stage, as far as defining the final contents that SENPLADES will later "process" is concerned is, thus, if not more important, certainly of more strategic value than the first stage. It is here that the final participatory stage of the plan takes place (not counting the final Assembly which is a more symbolic event) and it is also here that the final issues to be taken into the plan are established. But perhaps more importantly for my purposes, it is here that issues are given concrete shape. For example, it is here that an issue like transportation will acquire concrete conceptual boundaries. Therefore, in order to understand the effects of participation on eventual policies, understanding the second stage of the participatory workshops is clearly of special importance. Hence, I conducted research on a significant sample of 
workshops from the second stage of participatory planning.

The method ${ }^{26}$ employed consisted largely of a combination of ethnographic observation (which is not say that this case-study could be considered an "ethnography" of participation), discourse analysis and Dean's analytics-ofgovernment approach. The sample of the workshops was determined somewhat arbitrarily but with the aim of capturing the following elements of the workshops:

a. Regional balance (obtaining a sample from the different regions of Ecuador: Coastal region; Amazonian region and highland region.)

b. A relatively large number of workshops (13): more than half of the total At the same time it must be noted that all of the workshops, in principle, follow the same methodology. There was a clear procedural methodology (see below) that SENPLADES officials followed during workshops. In this sense, while the content and interactions of the workshops changed, many of the same issues, procedures and outcomes were the same.

Concretely, my method consisted in participatory observation during workshops. This entails being present in the workshops like any of the other participants. I was given the same materials that the participants received; I was present and participated in the various stages of the workshop from plenary sessions to working groups. During breaks I interacted with participants and, of course exchanged ideas about the workshops. This "ethnographic" element of my method also relied on interviews with participants and SENPLADES's organizers.

\footnotetext{
${ }^{26}$ A thorough explanation of my methodology and specific method is presented in Chapter One. This section is limited to explaining the deployment of some of my research methods in the context of the PNBV workshops.
} 
Ethnography also entails collecting data about participants: I was, for example, interested in who was participating, whether for example visible minorities were represented as well as the gender differentials. In addition, I collected data regarding the participants' affiliation to popular or other organizations; I was, furthermore, interested in who spoke and when.

The second component of my method comes from Mitchel Dean's analytics of government method. Dean's method consists in focusing on the acts of government and generating "how" questions in order to capture and understand the regimes of practices that constitute government. As Dean (1999: 33) puts it, "an analytics of government takes as its central concern how we govern and are governed within different regimes, and the conditions under which such regimes emerge, continue to operate and are transformed. An analytics of government thus emphasizes 'how' questions." Particularly, 'how do we govern?' and 'how are we governed?' As mentioned in an earlier chapter this entails looking at specific techniques of government, materials used to render them effective; to analyze waiting periods, the use of forms and locales of government (physical and symbolic), information etc. (Dean, 1999: 39). In this sense, I was interested in the materials government officials used during participation workshops and how these were employed and what kind of effect that had on participation; I also looked at the temporal distribution and organization of the workshops and their location. Finally, I was interested in the type, distribution and circulation of information during the workshops. Overall, my aim was to understand how participation was governed through the very things that made it possible. 
Map 3. SENPLADES' regional subdivisions

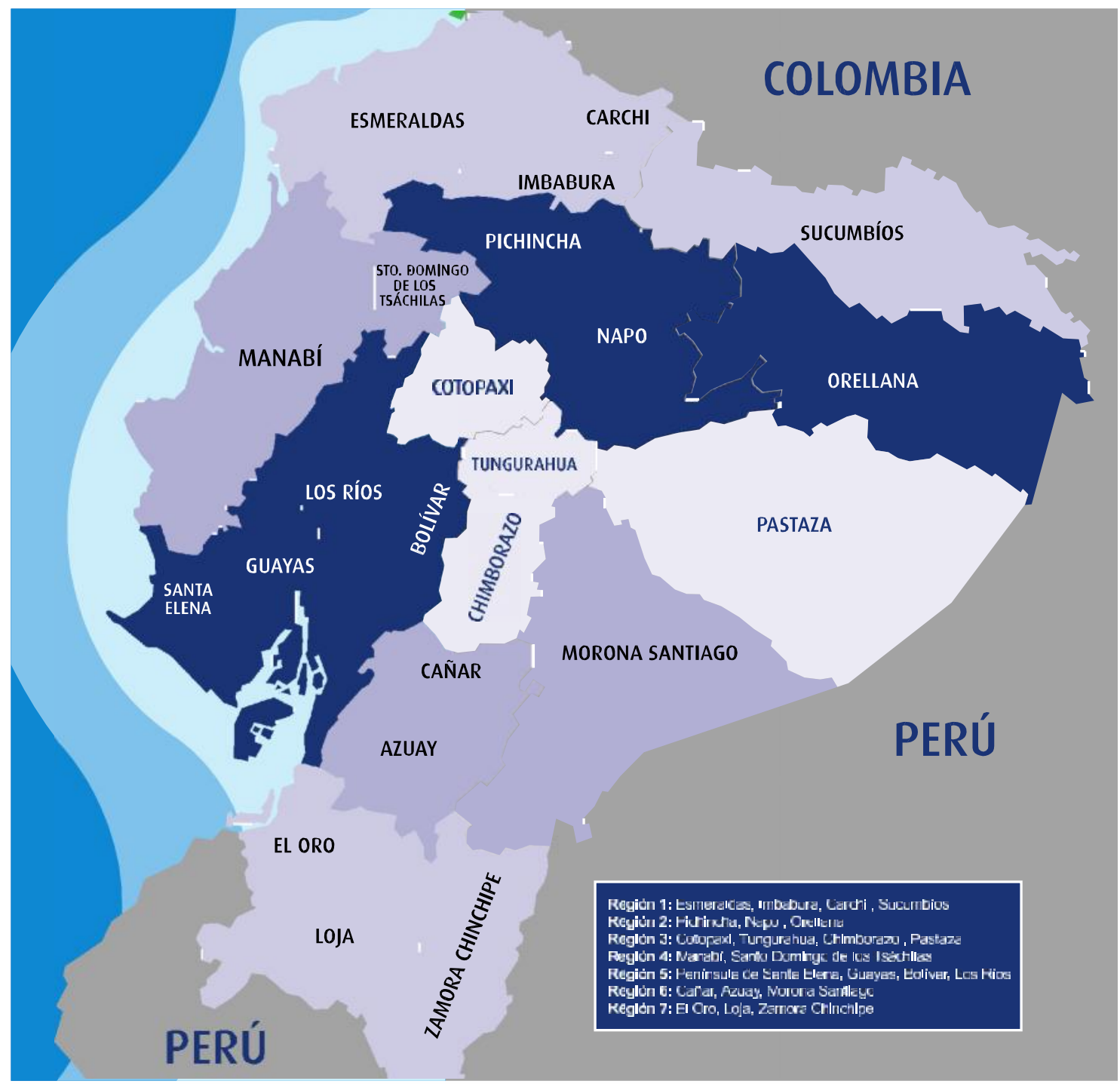

Source: SENPLADES, 2013: http://www.planificacion.gob.ec/wpcontent/uploads/downloads/2012/08/SENPLADES-Que-hacemos-y-quienes-somos.pdf

Finally, both the process of observation and analytics-of-government method were accompanied by a discourse analysis of the workshops. This included establishing relationship between the circulation of ideas and the participants who uttered them (was a participant a man or woman? Indigenous or not? Representing an organization?) I also looked at the way in which narratives were confronted and which of those narratives became successful at entering into the "policy" roster of 
the government and eventually into the PNBV.

\section{PNBV Workshops: The Organization and Selection of Participants}

The organization of the workshops relied principally on the work of local government officials (Anonymous Interview, February 14th 2014). There are a few ways in which this was done. Drawing from the workshops I attended and documented, I was able to identify four different types of organizations and participants present in workshops. First, what seemed to be political allies/supporters of the regime; second, representative of small-scale popular organizations; third, local political bosses; and, much less commonly, individuals unrelated to any of the other categories but that resided in the specific zone of the workshop. There was great variation, from workshop to workshop, in the number of participants present and their affiliations. There was an important emphasis, however, on two sets of participants, representatives of organized civil society and political supporters of the Correa government. There was also an important emphasis on local political bosses (called tenientes politicos) ${ }^{27}$.

Notwithstanding the relatively large presence of local organizations' representatives, two important qualifiers are in order. The first is that, in the case of organizations' representatives whose political position was unclear, the organizations they represented were very small in scale and for the most part, from

\footnotetext{
${ }^{27}$ Strictly defined, in legal terms, a Teniente Politico, is the representative of the provincial governor in small territorial units (called parroquias). However, the role of the teniente politico is often more than its legal attributes would reveal. Tenientes Politicos can act as political brokers between state representatives and local families and organized groups in the community; they can also act as political brokers in local disputes over land, livestock and even domestic disputes.
} 
what I was able to learn from interviews, conversations and through my own participation in the workshops, these were highly dispersed organizations, not very active politically and whose concerns were very local in nature.

The other aspect that is worth mentioning is these organizations seemed to have very weak internal structures. The "representatives" I am speaking of were, in many instances not designated on the basis of electoral or other means of leadership selection akin to a well-structured organization. There is one emblematic example of this, in the case of one Region 1, in which one of the local representatives was a very young woman, perhaps underage, who came unaccompanied and who stated that she was "sent" by people in the community to the workshop. In other instances like in the Workshops in Latacunga (Region 3) and Quito (Region 2) some of the representatives came out of personal interest not in formal representation of an organization.

Thus, what I concluded after an analysis of the relationship between the selection process of participants and the actual representatives that came and participated in the workshops is not that SENPLADES favoured local organizations or that organizational strength was a concern during the selection process, but rather, that 1. It was that participants happened to belong to an organization. 2. That contacting individuals who belonged to an organization was a more practical way of contacting people for local SENPLADES representatives. My conclusion in this respect was somewhat confirmed by a high-level SENPLADES technocrat working on the overall organization of the workshops who when asked about the logic behind the selection of participants, replied in an almost dismissive tone "we simply 
put that in the hands of local SENPLADES offices - they decided" (Anonymous Interview, Quito, February 14th 2013 ). Hence, a more adequate depiction of the composition of participants is that they were a collection of individuals who happened to be members of local organizations and had linkages with local state

representatives. After all, as Manuel Chiriboga points out, a characteristic of Ecuadorian society is that a large number of its members belong to an organization but also that a relatively large number of those organizations are inactive (Chiriboga, 2010).

\section{The PNBV Workshops: The Procedural Structure of the Workshops}

The workshops started with a rather long introduction (around 45 minutes) given by a SENPLADES's “technician." After the introductory talk, participants were divided into groups (except for the Quito workshop because of its low number of participants - less than 20), according to the sub-zones they belonged to. It is here, once participants were divided into smaller groups/tables, that participation was supposed to really begin. The first set of discussions took place through lengthy interventions by table representatives articulating the needs of each working group. There are a few issues that are worth highlighting from the first round of interventions. First, that the first set of interventions was characterized by palpable political overtones, particularly about the failure of the state, its lies, corruption, ineffectiveness and in most instances about its absence. As one participant from Esmeraldas, a fisherman, put it during one of his interventions, "the problem has always been that we have been abandoned by the state" (Anonymous Participant, 
Ibarra Workshop, Ibarra, 2013). Second, interventions were mainly about needs and demands upon the state. These two points were invariably salient in all of the workshops I attended and documented.

One of the first instances, of participatory engagements, thus, takes place in the form of citizens expressing needs. The expectation being, as one indigenous community leader and academic told me in an interview: "the purpose of participation and the way in which we [indigenous communities] understand it is to express our needs and have influence over policy-making by having them included in real policies that will eventually have a positive impact in our communities" (Anonymous Interview, Quito, November 29th 2012). This opinion was also corroborated by several of the participants in the workshops I attended. As I detail below, however, this type of participation, namely, the untempered expression of needs and a politicized stance towards the state, went through a number of subsequent transformations. I find this aspect of participation particularly important because it involves detailing the micro-government of participation. As I argue below, the techniques used to "process" the demands and interventions of participants had a notorious governmental effect in them.

An additional preliminary issue that needs mentioning is that many of the state workers and their participatory techniques were developed and applied by the NGO world a decade or so before the advent of the post-2006 state (Anonymous Interview, Quito, June $10^{\text {th }}, 2012$ ). This is significant for at least three reasons: first, it signals a shift of the knowledge base of NGOs to the state; second, it shows that a great part of the techniques and mentalities of government at least at the micro 
level, like the workshops designed to build the PNBV I participated in, are variants and or direct replications of what NGOs did (and do) and therefore, analysis made of NGOs and their "developmental" techniques can be employed to analyze these techniques and their expected results; third, it signals the appearance of a new form of "developmental" state that is in some senses rooted in the mentalities that guided NGOs in their quest to foster development during neoliberalism (i.e. during the time when the dismantling of the state apparatus signified that NGOs covered a large portion of the social-reproductive and basic service provision that is associated with welfare states).

In contrast to the often radical and highly politicized content of participation in the 1960s (May of 68 being an emblematic example; 1968 being also the year that Paulo Freire published "Pedagogy of the Oppressed") the "NGOicization" of participation, especially in the 1990s, meant a different, quite different, in fact, form of participation. During the 1980s and 1990s, participation entered a new phase that saw much of its older discourse/practice leaving behind its grass-roots, mobilizing and radical tendencies (with notable exceptions, like the indigenous movement in Ecuador) to enter the realm of governmentality: the realm of the technical; of a power/knowledge institutional apparatus that attempts to redefine the "participatory subject" in fundamental ways through participatory techniques like the participatory rural appraisal (PRA), participatory learning in action (PLA) as well as others (Chambers, 2007; Cleaver, 2001, cf. 2003),

Following some of Foucault's theoretical contributions about governmental power, it could be argued that the transition from a street-based, class-based basis 
of participation, to one of government (in this case government by NGOs), signifies efforts to transform the "participatory subject" through acts of normalization and self-regulation. While the old participatory subjectivity was combative, the new participatory subject is encouraged to be responsive (to self regulate accordingly) to the methodological demands of experts and bureaucrats and participate within the confines of knowledge/power and methodological standards defined outside participatory processes themselves (Manzi, 2011; Ospina et al., 2009, Mosse, 2001; Ferguson, 1994). Governmentalized participation is less devoted to politicized struggles, political assemblies and political deliberation and more concerned with "development"; and these are two very different things (cf. Escobar, 1995).

\section{The PNBV Workshops, Problematization and Rendering Technical}

Following Li (2007: 7), I argue that acts of problematization are not separate from acts of rendering technical. I, moreover, consider it essential to point out the limits, both conceptually and empirically of this conceptual relationship. Problematization, as I have mentioned earlier, is difficult to avoid and need not lead to acts of depoliticization. Similarly, rendering a problem technical is not per-se an act of depoliticization, as Li argues (Ibid.). Acts of government require synthesis and simplification, both of which can be equated to acts of problematization and rendering technical. This is not only the case theoretically, but also from an empirical stance: I observed how participatory processes began as political acts of problematization when community members sought to link their community problems to issues pertaining to rights, justice, equality or development. In 
addition, rendering technical can be the product of a political process. As I will show later, it was only when acts of problematization were linked to a problemsolving "tool kit" and expert knowledge became a dominant form of interpretation that political expressions progressively left the realm of what could broadly be considered 'politics', and entered that of technical solutions, hierarchies of knowledge and expertise (cf. Mosse, 2001: 16).

The PNBV Workshops: Making Participation Work - The Tools of Participatory planning

The first of the tools for "processing" demands during the PNBV workshops was to manage information. This is an important step not only for its practical necessity but because it meant capturing the expressions of community members, many of them politically charged ${ }^{28}$, into a series of "manageable" statements. SENPLADES did this by treating the claims made by community representatives as technical claims. For example, during the Latacunga workshop, during a discussion about water resources, the issue of racism and corruption was brought up. In particular, the issues as one of the participants noted, was that mid-range state representatives mistreated indigenous peoples, particularly women. State officials, the woman said, were rude towards them, treated them badly because they were Indians, often refusing to deal with their cases (Latacunga workshop, field notes, 2012). While her complaint was acknowledged, the real issue that emerged out of

\footnotetext{
${ }^{28}$ By politically charged I mean expressions of discontent that go beyond mere infrastructural or economic complaints. These were expressions of opposition to a culture and a state found to be unjust, discriminatory and fundamentally marginalizing.
} 
the intervention was water recourses and irrigation and how to improve water access for rural communities, while the much more complex and political issues of racism were left aside for the more technical issue of efficient access to irrigation.

Simplification techniques, like annotating participants' demands on a board are part of the way in which governmental experts, like NGO experts (Biggs and Neame, 1995; Narayan, 2000, 2005), develop an "intelligible field" of intervention. Acts of problematization are acts of government and as acts of government they define, in important ways, the characteristics of state-society relationships and, thus, many aspects of processes of state formation and state reproduction (cf. Migdal, 1994; cf. Geertz, 1979). Simplification techniques, as well as other participatory techniques and methodologies (e.g. the "world café"29 technique) inscribe themselves in a governmental rationality that is made operable by technical knowledges, like, for example, knowledge about water irrigation systems. Technical issues, in contrast to more political and cultural issues like racism, can be dealt with technical tools where expertise and relatively unquestioned knowledge can be applied. In this sense government and technical knowledges go hand in hand.

Indeed, another apparent difference between a governmentalized form of participation and the more vocal participatory tradition of the 1960s, is the role of experts. While this was evident in my research of the PNBV workshops, it was also evident that this process was not the result of a desire to eliminate politics out of participation but a result of the fundamental conditions of encounter between

\footnotetext{
${ }^{29}$ The "world cafe" is a participatory methodology based on five components: 1. Setting; 2. Welcome and introduction; 3. Small group rounds; 4. Questions; 5. Harvest (World Café, 2014:

http://www.theworldcafe.com/method.html).
} 
experts and community members. Many of the interviews I held with participation experts working on the PNBV, were vocal about the importance of not playing the role of the expert in participatory workshops. Like a high-level government organizer said in reference to this issue: "it is the people who have to speak for themselves and our just job is simply to facilitate this process" (Anonymous interview, Quito August 15 1 th 2012). However, as argued above, the governmentalization of participation entails that power within participation does not reside in the experts alone. To the contrary, power is not possessed but exercised in a decentralized fashion; this becomes evident once one realizes that there is a power dynamic in the very construction of participation as a field to be governed or as a field that requires systematization and mingled in with "development" discourses (see Escobar, 1995).

In all of the ten participatory workshops I collected information from, a pattern of power dynamics quickly emerged and, as mentioned above, this was not a result of someone seeking to possess power or the effect of the institutional power "possessed" by government experts. This became evident in various ways, one of them resulting from the fact that participants themselves "understood" that the complexity of their demands "had" to be simplified in order to be collected by the state. This was clearly a form of power being exercised without any one actively trying to wield that power. This power relationship was rooted in the fact that the expressions made by participants were treated as demands on the state, not as stances towards the state. Demands can be put down in paper in condensed form and the processes by experts who know how best to deal with them, while political 
stances require deeper acts of debate, deliberation, and, above all a reconfiguring of power relations. At the early stages of the PNBV workshops however, it became clear that politics was beyond the scope of participation as understood by the state.

\section{The Workshop's Agenda: The Introduction}

a. Governmentalizing Participation: "The Public," The State and Government

The agenda of the workshops always included, first, an intervention by a government official. This speech-like intervention generally lasted longer than any of the interventions made by participants, generally between thirty and forty-five minutes (see Appendix 1 for a table of variations and agendas). These interventions were discursively quite rich. In all of the cases I obtained data from, the governmental expert-organizer (generally a program official from SENPLADES or one of its local branches) presented a vision of what participation meant and how the workshop was a practical representation of such a vision. The emphasis was on portraying participation as the joint construction between citizens and state within a context of an inclusionary democracy. Emphasis was placed on the way in which participants should interpret the workshops. In particular, governmental officials were insistent that these workshops were the fulfillment of a governmental promise to build a participatory state through the PNBV.

There was an interesting and recurring association between the public and the state. Like in many governmental documents and speeches one of the most common justifications for a larger state is the need to repair the damage caused by neoliberalism, particularly to state capacities to provide basic services. But beyond 
the idea to reconstitute the state a more complex and elaborate conceptual association is continuously made between "the public" and the state -- the PNBV workshops were no exception to this trend. In most of the introductions to the workshops SENPLADES' representatives devoted considerable time stating the importance of recuperating public spaces and the "public" more generally (Field notes, Latacunga Workshop, 2012) through state intervention. It became clear that without the state the "public" could no be fulfilled.

What I found particularly revealing is that the "public" is never fully definedat least not in specific terms. The public, as a signifier is generally left empty. Following a Laclau-inspired (Laclau, 2004) line of interpretation, it could be argued that "the public" plays the role of what Laclau calls an 'empty signifier.' In his seminal work on populism Laclau analyzes the discursive conditions for the emergence of populism by constructing a theoretical argument around the concept of a discursive dispositif called the empty signifier. Broadly speaking the empty signifier operates discursively to create equivalences between quite distinct popular demands. Laclau's basic idea is that a discursive dispositif like, for example, "the public" or lo publico (that which is in the realm of the non-private) which can mean different things at different times and its real significance is only strategic - strategic in the sense that "the people" (el pueblo) and lo popular emerge as a way of making otherwise disparate popular demands equivalent.

Looking at it from this perspective, the "public" can mean a public good, like a highway, as much as it can mean something else, like a new presidential airplane (see this association made by Correa during WPR, 2012, \#286). In the specific 
context of my research about the PNBV and PNBV workshops (as well as the ongoing construction of the post 2008-Ecuadorian state more generally) lo publico entails not only something that is non-private, but it encompasses a range of issues, like the vindication of justice, popular power, redistributive justice; the public could also entail the furthering of petroleum exploitation and/or the mining frontier. What is worth stressing here is the effort made by governmental narratives to portray the state as the only space where "the public" can truly emerge, unfold and flourish (see section on DINEIB for a more detailed discussion).

This point is significant for participation and government both at the macro levels of state construction and at the micro-level. By looking at indigenous public institutions this understanding of the relationship between the public and the state is used as a way of establishing fields where politics is appropriate (spaces within the state) and spaces where politics is not appropriate (the realm of society). As I show in Chapter Four, this view can be traced to Correa's own definition of the state as "the institutionalized representation of society" (WPR, 2012: \#295).

Finally, SENPLADES officials acting as political brokers devoted a large portion of their talks to listing and reading sections of the Constitution and governmental plans. There was a lot of emphasis put on the innovative aspects of the constitution and on how it was designed to promote participatory democracy and participation. The people were supposed to guide their own destinies, but like I said, always within or through the state. In this sense participation is constitutive of the construction of the state - the state as an effect. This section of the introductory talks was in all cases the longest and more detailed. It was interesting to see how 
officials were tirelessly pointing out how the Constitution reads in terms of participation, equality, resources democracy, and so on. It could be argued that these interventions denoted a state in transition: on the one hand SENPLADES officials spoke from within the structures of power based on discourses and governmentalized techniques about participation while appealing to older forms of state-society relations based on client-patron relations - the old and the new were converging in the PNBV workshops.

\section{c. Techniques of Participation}

Finally, the third important aspect of the Introduction was establishing the list of techniques that were going to bring about "true" participation. Specifically, this meant establishing the activities, distribution of participants, the modes of discussion, the form in which thematic areas would be approached, the time allowances for each of the activities as well as a general explanation of the materials to be used. Participation, as the table above shows, was divided into four stages. All of these stages would have to be carried out and processed within a day. As mentioned earlier, this was the second round of participatory meetings and was organized as a regional series of workshops. In the first round of workshops, all of which followed the same organizational/constitutive logic, participants were organized to establish a list of needs, proposals and general issues which they would later bring to the regional workshops.

A significant aspect of the introductory speeches made by SENPLADES organizers is that even though participation was encouraged, there was never an 
opening established to have the methodology of the workshop itself be subjected to participatory scrutiny. The introduction, in addition to all of the elements mentioned above, consisted in listing a definite set of tasks that needed to be carried out and the techniques that would be used to accomplish them.

\section{The Distribution of Time as a Technique of Government}

Before continuing with the other activities and elements of the workshops themselves, I should briefly discuss the larger organization of PNBV participatory processes, in particular, the question of time and the relationship between the time workshops take and the possibility of real participation. To begin with, the issue of scheduling and timing becomes evident when one asks, like I did to a SENPLADES organizer, about the time needed to promote participation. The organizer told me that there are important time constraints due to bureaucratic requirements and that there has to be a limit to the scope of participatory meetings (Anonymous Interview, Quito, February 14th 2013 ).

The overall construction of the PNBV is carried out over a series of meetings that range from the local to the regional to the national level. And admittedly, SENPLADES does seek to give some continuity to these participatory engagements as is evident from the continuous use of participatory planning techniques in the different PNBVs. People do participate and generate participatory outcomes in these meetings. Workshops begin with a series of local meetings that employ the same modalities and methodologies as the regional meetings I attended. According to this method, once priorities are set these are then discussed at the regional level in two 
or three different stages. Later there is a national convention where the PNBV is "approved." The final stage of the PNBV is "processed" and put together by SENPLADES” “technicians.”

There is one day devoted to each of the regional workshops. As the table above shows, all the twenty-four provinces and seven regions are "represented" in workshops and each workshop must "process" all the demands, claims, and voices of each region in one eight- to nine- hour day (with a lunch break in the middle). There is, therefore, an insistence by workshop organizers that participants must be executive in their interventions. As an organizer at the Riobamba workshop told participants at the introduction of the meeting "the amount of time we spend here will depend on you" - he was referring to how quickly they could finish the workshop in order to leave. In this respect there are two issues that are relevant and directly linked to the governmentalization of participation.

First, there is the "need" to have participants make short and succinct interventions. It is not that participants are forced to be brief in their interventions in any coercive or straightforward manner; to the contrary, the briefness of the interventions is presented as something that needs to be done for their own good and convenience. The second aspect is that one session of eight or nine hours does tire participants and, as attested by my observations and conversations with participants during the Ibarra workshop, a desire by participants to simply finish the meeting quickly in order to go back to their communities. This is especially the case of participants who must travel long distances to make it to the workshop. In the case of Ibarra (a city two and half hours north of Quito) (but also other 
workshops like Latacunga and even Quito) participants from Esmeraldas (a province to the north east of Quito) had to travel close to ten hours back to their communities (from Ibarra, back to the capital, Quito, a two hour trip and then from Quito by bus to their communities in the west province of Esmeraldas). I interviewed four of the participants from the Esmeraldas group (during the Ibarra Workshops), mesa and they all expressed a sense of urgency about finishing the meeting quickly in order to be able to start the long ride back to their communities as early as possible (Anonymous Interviews, Ibarra, September 25th 2012 ).

Participation under these circumstances becomes a controlled activity where little can be meaningfully discussed. There is, in this respect, a clear form of government of participation. This type of control or government of participation emanates from the organization of time, materials, activities and participants' desires (desires because the ways in which things are organized makes them want to be quick, executive and brief). But there are also other dimensions to the problem. From a gender perspective, it is a well-known phenomenon that women and men are not always in the same conditions to participate. Participation for women as the primary care-givers in many (or most) rural communities tends to be more complicated. This not only means that traveling long distances may be more difficult for certain women but also that women participate less and public speaking in a succinct, brief, synthesizing and executive manner is not always possible. In this sense their voices are heard less. There were a few examples of this in the workshops I attended. The issue became clear not only by the fact that the vast majority of interventions (and the ones with more factual information and 
knowledge-based statements) were given by men, but also by the direct confirmation of this problem by two of the women I spoke to (Anonymous Interviews, Latacunga, July $26^{\text {th }}, 2012$ ). Both mentioned the problem of distance travelling and the "habit" factor, that is, the fact that women have less experience in public speaking. A study of rural organizational strength in the Intag region of Ecuador shows similar results (Hildahl, 2011 - unpublished).

\section{Techniques of Intervention Continued: “Capturing" participation}

As mentioned above, the shortness and the scheduling characteristics of each workshop (one a day for eight or ten hours) meant that many of the topics ended up being treated very superficially. In fact, while mesa (small group discussions) discussions during workshops were more detailed, personal and political, the content that emerged from these discussions and that were going to be later processed by SENPLADES technocrats bore little resemblance to the discussions themselves. In a table in the city of Ibarra, the Esmeraldas representatives discussed the issue of transportation, for example. Transportation, it was said, was a problem for them. Transportation was interpreted as an economic dimension as products they produced could not be easily transported from their communities to the nearest commercial centre. Moreover, transportation was also attributed a cultural dimension by alluding to the difficulties in meeting communities and making purchases for cultural activities; similarly, it was given a political dimension by pointing out the difficulties in getting to organizations' meetings and political gatherings; there was also a health component as lack of proper roads means 
difficulties in getting to and from healthcare facilities. Aside from these issues, and given the coastal origin of the people from Esmeraldas, there were also discussions about transportation by water and the effects this had on fishing communities and the relationship between Colombian fishermen/women and Ecuadorian ones, and the role the state played in this relationship. Finally, all of these points were contextualized and framed through personal expressions of hardship and struggle and contextualized through questions of injustice, inequality, race (racism, really) (most of the Esmeraldas participants were Afroecuadorians) and the failure of the state and the system of democratic representation to take their needs into account.

The individual table dynamics, however, changed when it came time to present and systematize the results of group discussions at the request of SENPLADES technocrats. First, much of the personal content of interventions was largely lost and the politicized nature of table debates was largely diluted. This was the case in all but one of the workshops (the Riobamba one - see below). The first reason was the need to be executive. Time constraints required making issues more general and less geared towards specific community needs, or personal expressions of protest, and more about regional issues. While, again, there is nothing wrong with simplification, per se, in certain contexts, like the PNBV workshops it worked to dilute the effervescences of certain claims (particularly politically charged ones).

The second reason was the very techniques used to "capture" participation. The specific technique used was a mix of group dynamic techniques ("world café," classroom-style groups discussions) (Bastian and Bastian, 1996; Anonymous Interview, Quito, June 10 th 2 2012; February, 2012; Kothari, 2001). This consisted of, 
basically, group discussions about community problems. The idea behind the methodology was, of course, to capture the voices of the participants and express them as genuinely as possible (Anonymous Interview, August 15th 2012). However, it was far from clear that the participatory results captured SENPLADES technocrats were the genuine expression of participants. There were a number of issues that are worth pointing out. First, SENPLADES technocrats' way of organizing information was geared to expressing more in less space. This logic of expression is not necessarily sensitive to the more "lyrical" expressions of some participants, particularly Afroecuadorians.

Third, the difference between individual participants was rarely stressed by the organizers in an effort to make information manageable. There were differences in opinions about what governments should do, how, when, and why. For example, in the Latacunga workshop (region 3) these political tensions between participants themselves were "sacrificed" in order to obtain clear set of needs and demands. Thus, the overall workshop result was that political differences not only between state and participants but also participants themselves were brought into the realm of the technical. I find this point of particular importance because we see a microlevel manifestation of the depoliticizing tendencies of the state and, moreover, an empirical illustration of some of the theoretical postulates of this thesis, like the depoliticizing effects of rendering political issues technical (Li, 2007a, b).

Finally, the purpose of making information manageable was inscribed in a discourse of "needs and demands." SENPLADES and its technocrats rooted participation in a very old tradition of state-society relations based on needs and 
demands. This meant that making information more manageable meant taking the content of participatory workshops in such a way that it could be read as a list of needs and demands. The final results were a list of general points devoid of many of the particularities, specificities differences and tensions that emerged during mesa dialogues. Particularly issues that challenged the contemporary state were left unattended and the final "product" of the workshops reflected little political tensions.

The final list of items to be taken back to SENPLADES included such general things like: make land more productive (Latacunga workshop); improve connectivity (Ibarra and Quito workshops); improve economic opportunities (Latacunga workshop); increase access to health (Quito workshop); improve the provision of basic services (Quito workshop), etc. In other words, the participatorybased list of demands generated in plenary sessions were filled with things that the state is generally in charge of anyway. This fact, as mentioned above, begs the question: why participation? The answer I would like to suggest, relates to the overall argument of this work, participation and participatory planning are governmental techniques to produce the state effect and to bring about forms of control that go beyond repression, coercion and negation; participation in this sense is not a way to re-politicize society and bring about a bottom-up approach to social, political and economic change in Ecuador but to bring the state back into communities in a governmentalized fashion.

In sum, the demands-based "participation" that SENPLADES constructed articulates the relationship between society and state, not as the constitution 
indicates, as a political one based on the notion of participatory democracy, but as one in which citizens are there to place demands on the state and the state there to fulfill those wishes. It is a very apolitical process in which citizenship is limited to making demands. This has the further implication that citizenship becomes effective in two particular instances: during demand-based participatory processes and during elections (see below section on plebiscitary democracy).

\subsection{Reproducing the State: The PNBV Workshops and Micro spaces of Government}

As mentioned above, the PNBV workshops were largely organized by SENPLADES' offices at the local level. This is important for a number of reasons. The first is that my argument in this section should not be taken to mean that there is a new state form that is unilaterally penetrating society from scratch. I do, and have argued that a new form of state is operating and is being constructed in Ecuador. However, one of the more salient empirical observations from my field research is that the state, SENPLADES and many PNBV workshop participants were already operating within an established set of relations. Accordingly, participation was defined, to a large extent by this "language" of state-society relations. Specifically, I am referring to clientelism.

Following Migdal (1994) and Lemke (2007) I argue, that the way in which the state reproduces itself is by operating on pre-existing, informal (i.e. not derived from the content of written laws or regulations) social relations (see Ch. 2), some of these are sustained from the top-down, others from the bottom-up and others, on 
what could be called a horizontal correspondence. The importance for a strong state to develop ties with society is even recognized by the Weberian tradition. Peter Evans, for instance, shows how important webs of state-society relations are for, for instance, industrialization - hence his concept of embeddedness (Evans, 2004).

Similarly, the Ecuadorian state, while veering away from some of its previous forms (the Hacienda or neoliberal states), continues to operate on the basis of its links with local community elites, like tenientes politicos, university professors, and community organizers and or trade union leaders. As shown in Appendix 1 the presence of tenientes politicos, professors, and community organizers was rather large during workshops.

The point here is to emphasize the political nature of state-society relations. That is to say, my argument about depoliticization and the weakening of social organizations is not meant to be absolute and that state strategies, are always projects, not accomplishments; power and state reproduction, furthermore, depend on pre-existing social relations. It is also important to note that consolidating a state project, like the Correista state project, is not a unilateral venture. The state must negotiate; it must push and be firm as much as it needs to be flexible and concede certain points. In one of the workshops, the Riobamba one, for instance, tenientes politicos constituted almost all of the participants in the workshop. An analysis of this workshop allowed me to identify three important factors.

First, there was a much clearer emphasis on bringing the "word of the state" (Riobamba workshop, participant's speech) into communities. Many of the tenientes 
politicos emphasized their association to the state and their role as brokers (links between state and communities). This role as "brokers" and their loyalty to Correismo, was their "offer" to the state. The second point of difference was the frequency with which SENPLADES officials mentioned politically sensitive issues that had no direct relationship to the workshop like the communications law, the political opposition in Quito, the need to generate local support to attain "Buen Vivir". While in all other workshops SENPLADES officials took the opportunity to emphasize the good deeds of the Correa government and the wrong-headedness of the opposition, in Riobamba the political tone was much more combative and confrontational as if to generate support from those present. In this respect SENPLADES officials emphasized the need for the participants who were present "to go back to their communities and organize participatory processes" (Anonymous Interview, Quito, June 10 $10^{\text {th }}, 2012$; Anonymous Interview, Quito August $15^{\text {th }}, 2012$ ).

Finally, the participation of local political brokers revealed the complexity of political relationships at the local level (at the level of rural parroquias, mainly). In most of the workshops I noted this phenomenon but in the Riobamba workshop it became a lot more salient. That is, much of what participants demanded from the state was to intervene to settle local disputes and confrontations. Three of the participants in the workshop, two mestizos and one indigenous, for instance, mentioned that participation does not really exist, not even at the level of local governments; that small factions of "friends and associates" occupy spaces of participation and that, at the level of local parroquias no real political participation exists. In sum, at the local level the absence of an institutionalized state was evident 
and the perception of participants that the state was a force that could settle political disputes (perhaps in their favour?) was also clear. Thus, while the state is both operating on the basis of existing social structures and local political relations and opening new ones, it still has much work ahead of itself. Put differently, the Correista state project is only partial and limited, and even though, it is a depoliticizing state form, it still relies on local political relations to operate and must contend with local political battles in order to fully penetrate society.

\subsection{Subalternity and the PNBV Workshops}

The PNBV workshops like most of the Ecuadorian state and in particular the Executive branch were permeated by the encounter of multiple discourses, particularly, $S K$ and developmentalism. To end my discussion of the PNBV workshops, thus, I would like to ask: how did this tension manifest itself in the workshops? What was the role of the state in managing it? My approach to answering these questions is in itself nothing new. Particularly, employing a Foucauldian approach, I would like to point to how inequities made visible knowledge differentials and hegemonic discourses during workshops.

One of the most pervasive and noticeable aspects had to do precisely with the way in which ideas, dialogues and, particularly, debates were constructed and transformed from the "micro spaces" of tables to the macro-spaces of plenary discussions and ultimately the "products" SENPLADES officials used to construct the PNBV. Notwithstanding the sensitivity and knowledge of individual technocrats regarding differences between participants (according to race, gender and class), 
the imperative of making participation a part of a governmental duty through a series of methodological tools, ended up rendering those differences invisible. This problematic within participatory approaches to development has been widely criticized and it is not unique to the Ecuadorian case, of course (see Cooke, 2004, Cleaver, 1999). Part of the governmentalization of participation in effect produced the undesired effect of capturing the voices of those who one would have expected to be more vocal about contentious issues: mestizo educated men (not surprisingly in a machista society like Ecuador's).

During workshops (except in the grand PNBV assembly carried out this year and the Guayaquil workshop), and given the participatory techniques employed the influence of certain groups within each table became very noticeable. Educated mestizo men, for example, did not necessarily monopolize table discussions in terms of time, what was more vulnerable to monopolization was the synthesis of demands and debates. More educated, urban individuals (mainly men) were more equipped to synthesize and be "executive" about issues and therefore adapt to the governmentalized participatory techniques of SENPLADES. It is precisely because of this process that the diversity of cultural forms of expression, gender perspectives, race and so on, was almost entirely lost.

There are two emblematic examples of this phenomenon. At the Latacunga workshop an intellectual with a long trajectory of participation in social movements and an evident preference for orthodox Marxist interpretations translated indigenous demands about race and lack of state attention to questions of class struggle and the oppression of traditional elites. While he may have been "right" 
about elites that racism cannot be reduced to class differentials (see Wade, 1993, 2004). Similarly, the indigenous woman at the workshop spoke of racism at the level of popular classes not across classes. Her specific example was that of rural state officials not attending to indigenous peoples because of their indigenous origins. Clearly, low-ranked mestizo state officials in a rural community in the province of Cotopaxi (see Map 3) are not members of traditional elites or are structurally located in a position of relative power.

A similar example occurred in the Ibarra workshop. Afroecuadorian peasants and fishermen from Esmeraldas spoke of bringing roads to their communities and improving communications between communities. The discussion was, I would argue, about isolation in a wider sense; it was about connectivity and, I would say a general stance about the "isolation" or, more appropriately, the exclusion of Afroecuadorian peoples. However, at the moment of synthesizing this point and writing it down in one of the large sheets of paper given by SENPLADES, the discussion, mainly between a high school and a university instructor working in Esmeraldas, was about the best way to express distance and efficiency in transportation: was it a question of improving main highways connecting communities to commercial centres? Was connectivity to be measured in kilometers spent on a road or time spent transporting goods? Was the issue to improve roads between small communities? In other words, the overall output of the table on this topic was about road efficiency and not about the larger meaning of isolation of Afroecuadorian peoples.

Before I conclude I would like to bring up a few important points that a 
governmentality approach is likely to highlight. First, even though some of the meaning and voices of Afroecuadorian peoples, women and/or indigenous peoples were lost, I did not observe that these groups were purposefully excluded or that animosity existed during table discussions as a result of race or gender issues (there were heated discussion about other issues, indeed). In fact, all groups mentioned above, became concerned with the task of making their table "outputs" as succinct, clear and "manageable" as possible. During the first rounds people expressed themselves in a politically and culturally charged way, however, once it was time to "get things done" there was an evident process of self-management in which individuals and groups became concerned with the process of synthesizing. This is, I would argue, a clear example of a form of government at a distance, albeit in a micro-scale. Even though the people of SENPLADES did intervene in asking people to avoid tangential conversations and to be clear, there was never opposition to such demands, to the contrary, participation became, unintentionally, I would contend, about fulfilling the technocratic requirements/obligations of the workshop and not, as the SENPLADES people I interviewed themselves would have put it, about "capturing the voices of the people," which, I would argue must reflect aspects of their politicized positions. In other words, the governmentalization of participation as far as the PNBV workshops are concerned, can have the unintended effect of accentuating social inequities.

\section{Conclusion}


My analysis of the PNBV shows that participation is engulfed in a specific form of governmentality: the technocratization of participation (participation for itself) and the promotion of a passive, demands-based form of citizenship. There have been multiple studies, that, in similar fashion demonstrate that "participatory" processes, particularly those in the context of previous consultation tend to produce similar effects. One of the arguments I presented here, and indeed throughout this work, is that the politicized form of citizenship promoted and embraced by the Constitution and indigenous communities is largely absent and in its stead the state has adopted a strategy of state consolidation through various forms of governmentality to construct a passive, individualizing, demands-based, depoliticized, non-political form of citizenship. However, and at the same time, it is fundamental to stress the importance of understanding/interpreting the "antipolitics" tendencies within the state as a project, not an accomplishment. In other words, the project of construction of passive subjectivities is always subject to challenges, variations, changes, and setbacks. What this chapter suggests is that, among other things, that insofar as my research on participation and state strategies of power that at the very centre of the state project lies a tendency to de-radicalize politics, governmentalize participation and portray the state and its institutions as the only legitimate spaces for political practices - but once politics enter the state machinery they become depoliticized through a myriad of techniques and technocratic processes which seek to pull politics away from acts of confrontation between opposites. In the section that follows I analyze the role that the electoral system has played in the construction of participation since 2008 . 


\section{OTHER MODALITIES OF PARTICIPATION}

\subsection{The Case of "Plebiscitary Democracy" 30 and Liberal techniques of Rule}

One of the final aspects of State construction and the construction of government that will be addressed in this chapter is the issue of electoral democracy and its relationship to both state consolidation and governmental forms. There are three aspects of the constitution of this power resource that I will address: first, its relationship to populations; second, its relationship to participation; and third, plebiscitary power as a form of government.

As mentioned in Chapter One, the frequency of electoral processes (including plebiscites, regular elections and referenda) since 2007 (nine processes in total) has been unprecedented in Ecuador's history. It should be noted that all of these processes have resulted in Correista victories. According to Catharine Conaghan and Carlos de la Torre there is a direct link between the power that Correa holds and the large number of electoral/plebiscitary processes Ecuador has seen (Conaghan and De la Torre, 2009). This form of reasoning is quite straightforward: winning elections award political capital to the victorious parties. But these authors stop short of analyzing the full implications and governmental dimensions of what they call "plebiscitary democracy." After all, institutional power and electoral processes should not, especially in Ecuador, be automatically related, as the political and electoral crisis that preceded Correismo demonstrates.

\footnotetext{
${ }^{30} \mathrm{I}$ borrow this term from Conaghan and de la Torre, 2008.
} 
In an exercise of mainstream liberal-institutionalist critique they argue that the problem of plebiscitary democracy is harmful for the development of a true democratic system. But, as mentioned in Chapter Two, this type of analysis is incomplete at best and highly problematic at worst. First, it conceives of and analyzes electoral processes always in contrast to an idealized form of democracy whose conditions of existence may or may not exist in Ecuador today. Many insitutionalist analyses about Ecuador is at fault in that their analytical work is often linked to a theory of correspondence between "reality" and idealized democracy. However, it is often the case, like in the case of Conaghan and de la Torre (2008), as well as others like Pachano's and García's (2013) that the conditions of possibility for such an ideal are rarely analyzed thus producing analyses that often share a similar diagnostic: Ecuador's democracy is underperforming in one or more aspects.

While a political project demanding a more ethical conduct of politics or respect for written laws and regulations is clearly desirable as a form of political analysis, the aforementioned approach needs to be complemented and/or replaced. In the case of plebiscitary democracy, one cannot limit oneself to a critique of how the frequent use of electoral processes is damaging a supposed and completely hypothetical road to democracy, without, of course, first justifying the hypothesized road. By contrast, here I argue that plebiscitary democracy is part of the conditions of existence of an actual governmental regime that is partly defined by the constitution of (or the project to construct) passive citizens. In this sense, I would not contend that plebiscitary democracy is an obstacle to democracy (although it 
may very well be) but that it performs a contingent function in the construction and consolidation of a State project since 2007.

To analyze the issue of plebiscitary democracy, I would like to begin by bringing back into the discussion the issue of populations and individualizing citizenship. Populations at large, as explained earlier, require processes of homogenization which entail that people are at once unified and dispersed: unified as population and defined by specialized knowledges about it and dispersed because populations have no organic (or bottom-up) agency (e.g. a social movement, a party, a union, etc.) (cf. Cohen and Arato, 2003; Tilly, 1984). Thus far I have shown some of the state-development and consolidation strategies to be rooted in a conception and practice of a depoliticized and individualizing citizenship. In what follows I would like to show the way in which the frequent use of electoral processes is a constitutive factor in the practice of this form of citizenship and an significant component in the rearticulation and potential consolidation of the state.

\subsection{Plebiscitary Democracy and Political Parties}

First, elections are indeed a political exercise of citizenship; unlike participatory forms of citizenship, voting is an individual exercise but the aggregation of votes constitutes an expression of community. It is important to note that in many states, take Canada, for example, elections are directly linked to partysystems. However, in the case of Ecuador the presence of elections and plebiscites is accompanied, it should be emphasized, with the dissolution of a party system. In this sense, elections are not being carried out as liberal democratic party theory would 
have it (see for instance, Mainwaring and Torcal, 2005; Sartori, 2005), in a context in which parties represent socio-political positions within society and as institutionalized spaces where politics outside the confines of the state can take place. Since 2007, there has been a consistent decline in political parties almost to the point of their complete disappearance (Pachano, 2010). Rafael Correa's party itself is called a "movement" and parties are decried by Correa himself as sources of Ecuador's recent political crises and symptomatic of a type of oligarchical domination of the state (Conaghan and de la Torre, 2008). Ecuador's electoral system is composed of so-called "movements." The institutionalization of these movements takes places via a highly controversial process of signature collection and the approval by the Electoral Council of the State (CNE, 2013). Thus, the traditional sense of political party representation and political activism is nonexistent and the majority of the population engages in electoral processes as individuals without formal political affiliations.

The crisis in the party system has been a long and progressive development and cannot, of course be attributed to the advent of Correismo (Andrade, 2012). However, since Correa, one of the governmentalities of elections has been to dismantle the party system and put in its place an amorphous system based, like I said before on political "movements" whose existence depends on the collection of signatures and not on its organic links (class, race, gender, policy preference, political orientation) to society. One of Correa's most active battles has been against organized political parties, so much so that he coined the term "partyocracy." Thus, through a series of reforms and political manoeuvres 
traditional parties have disappeared for all practical purposes (Moncayo, 2010; Ellner, 2012). Thus, the last Presidential election, carried out in February 2013, as Jorge Leon Trujillo (2013) points out, was mainly characterized by a wide sense of depoliticization and apathy (Trujillo, 2013).

\subsection{Plebiscitary Democracy and Citizenship}

Since 2007, there have been over 9 electoral/plebiscitary processes in Ecuador, directly linked to state reforms and the figure of Rafael Correa and his presidency. That means, on average, two per year. According to the presidentialist, unicameral system of Ecuador, there should have been only two elections in the 2007-2013 period (Constitution of Ecuador, 2008). In relation to this impressive number of electoral and plebiscitary processes Correa formulates the rhetorical question: “what more participatory democracy [do you want]?” (WR, 2010: \#260). What Correa implied by the rhetorical question was that there is already enough participatory democracy, that people should be content with the type and forms of participation available. And indeed, if populations/individuals are the objects of participation, development and citizenship, it is not surprising that the notion of elections and plebiscites be equated with the furthering of participation.

Elections and plebiscites, instead, have become part of a strategy of delimiting the arena of legitimate political expression and political discussion. Specifically, winning elections has become the most important credential for political activism. This strategy echoes a phenomenon I mentioned earlier, namely, defining the state as the appropriate space for political action, while denouncing political action 
beyond the confines of the state as illegitimate. When faced with political opposition, programmatic criticisms, or general criticism for that matter, Correa often appeals to the issue of his continued electoral success as a marker for political legitimacy. Take for instance the following statement

The agenda of the party that won the elections must be respected and not that of a minority that obtained $2 \%$ of the vote ... If 10 families in a community say they don't want a hydroelectric plant, the country will be left without electricity and they don't understand that besides of being illegitimate they are helping neoliberalism which destroyed the state" (El Comercio, 2008: http://www.elcomercio.com/noticias/CONAIEresentida-declaraciones-Correa_0_165587263.html).

State institutions like the parliament and the electoral council, I must point out, also echo the plebiscitary strategy promoted by Correa and the Executive branch. For instance, the high number of elections, referenda and plebiscites is a result of extra-institutional arrangements originating from initiatives from the executive branch (in other words, most of these electoral processes have not been the result of ordinary legal scheduling) that have counted on the support of these institutions. This signals a state and, in particular an Executive Branch, which promotes a vision of politics that remains largely "dependent" on the recurrent and regular holding of electoral processes. From the point of view of discourse and power resources, restricting the field of politics through electoral means entails pursuing a form of government of social forces which is clearly represented by the following statement made by Correa in reference to indigenous peoples' criticisms 
of his government "[why] will they tell us what to do ... if they do not win elections?" (WPR, 2012: \#261).

In addition, there is a further governmental effect in the exercise of plebiscitary politics: populations are mobilized to formally take part in a democratic process of expressing their voices; however, the effects produced by the constant mobilization of the population in favour of the regime go beyond electing an incumbent or manifesting their opinion about an certain issue. In other words, populations are mobilized as part of a governmental strategy to control the political arena beyond the context of elections.

But the interesting thing about the 2010 referendum is that there were questions ranging from regulating bullfights to the restructuring of the Ecuadorian Justice System. Surely, however, it can be said that there is little significance for Ecuador's political system in whether bullfights continue their questionable tradition of killing the bull during the bullfight or not. There is, then, a larger governmental effect that the mobilization of a very large part of the population through elections goes beyond the issue of bullfighting or people's democratic ability to express their opinions about it. The plebiscite reaffirms a governmental practice that defines electoral politics as the most important and recurrent enabling factor for political action: “if you don't win elections you should not speak about political matters."

\subsection{2 “Other States: and Forms of Participation}


While my overall argument hinges upon the notion of governmentalized participation, it is important and methodologically prudent to emphasize other dimensions of the state. It is evident, I would argue, that while different, the Ecuadorian state continues could be defined, in some respects, according to what Laclau calls "populism" (Laclau, 2004). It is important to highlight this in order to place limits on the extent and reach of my main argument: the Ecuadorian state is not, altogether, a modern state whose main power modality is governmentality and whose logic of rule hinges on technocratic forms of government. As mentioned earlier, the governmentalization of the state is a gradual process and a historical tendency that I have identified as being central to state development since 2007, but it is not the only one. Other state forms continue to operate, albeit in a more limited fashion (relative to the past).

As far as participation is concerned the two most consistent (temporally speaking) expressions of a theatre state are gabinetes itinerantes (itinerant cabinets -IC-) and enlaces ciudadanos (weekly presidential reports -WPR-). These participatory processes are not, I contend, governmentalizing forms of participation in the sense mentioned earlier. These are expressions, rather, of a theater state that governs through pomp and fanfare, through symbolic gestures and tradition. In practice, WPRs are weekly, three-hour meetings between the President of the Republic and other high-ranking government officials with different communities. Since 2009 there have been nearly four hundred WPRs and almost as many ICs (Presidency of the Republic, 2013). WPRs take place in front of small (200 people) medium (500 people) and large audiences (3500 people and above) (WPR, 340: 
00:14:00-) and are broadcasted live to the entire country through television and radio - in this sense the real audience is much larger than those physically present in meetings. The WPR are, according to the Office of the President, a form of accountability. The president tells the people how government is being conducted, what his agenda was in the previous week and how the general aspects of government are being managed. WPR are presented, thus, as a democratic exercise of accountability.

Of particular importance in the "reporting of activities" is the relevance given to the technocratic character of the state and its experts (beginning with the President himself). Many WPRs are devoted to developing a governmental runthrough of problems (act of problematization) and the appropriate knowledge and techniques to resolve the problem (rendering technical). Thus, during WPRs the state (and its government) appears knowledgeable and as a problem-solving machine which possesses the knowledge and will to tackle society's pressing problems. In this sense WPRs are a form of rule linked to the governmentalizing processes of state formation mentioned earlier. Society (it must be remembered that WPRs are live events watched and listened to by live audiences as well as millions of Ecuadorians via television and radio) and the state are therefore linked through a governmental logic that depicts the state as a source of wellbeing for the population resulting from its knowledge, techniques and capabilities.

ICs, on the other hand, are travelling cabinets where the President of the Republic and his cabinet ministers gather in different communities across the country. ICs, like WPRs often take place in areas where high-level public officials 
have rarely, if ever, appeared. As Patricia Munoz notes, ICs differ from previous cabinet meeting forms in that, instead of being closed-door encounters, these are open gatherings of which people can feel a part (Muñoz, 2010: 162-164). ICs are meeting where the President and Cabinet discuss issues of public interest in a highly technocratic manner. As Luis Davila points out, ICs take place "in modest locales, with ministers dressed informally and sitting in a circle. After the meeting, ministers talk to the people, generally in a classroom of a school. Time for festivities is always allotted, the president rises early to go for bicycle rides and the whole thing finishes with a radio program [WPR] which people of the zone attend" (Davila, as cited in Muñoz, 2010: 162).

ICs, unlike WPRs, are more geared towards direct interaction between community members and state officials. Generally, as mentioned by Davila, following the meeting with the President, Ministers gather in public spaces to listen to peoples' demands. People's participation during ICs consists, mainly, in placing demands to the state via cabinet ministers and other state officials. Demands to public officials are placed verbally or through petition cards. Petition cards are relatively small sheets of paper (smaller than a standard A4 format sheet) where community members write their contact information and demands. Their demands are written in a small space at the bottom of the sheet (approximately a $5 \times 15 \mathrm{~cm}$ space).

There are a number of conclusions that can be drawn from analyzing of participation in both WPRs and ICs. As far as WPRs are concern, it is clear that participation is relatively passive insofar as it is the state and its government who 
speak, interpret and frame issues; it is the state that creates its own regimes of representation for its audiences. Not all audiences are passive, of course, but participation in WPRs and ICs are essentially places designed in such a way as to convey a regime-friendly environment. Dissent, as illustrated by WPR \# 277 (2012), is met with disciplinary measures (see below). ICs, do involve a higher measure of active participation. But participation even if more active, remains limited to making demands to the regime: a form of participation rooted in a patron-client relationship. These demands can only contain a limited amount of information given the limited space in which they can be expressed.

The participatory implications of WPRs and ICs are more about, as Muñoz (2010) puts it, establishing political (electoral) bases of support for the regime. Nonetheless, and notwithstanding the importance of a live audience for WPRs and ICs, it must be emphasized that the opportunities for full democratic participation are rather limited. The type of participation emerging from WPRs and ICs could be defined, following Andres Guerrero (2010) as a ventriloquist form of participation in which popular voices are appropriated by the state through a series of limited openings, like having little space to write one's demands upon the regime and more overt limitations like facing disciplinary actions for expressing dissent. Of all the WPRs analyzed in this work there were only one instance of overt dissent. Both of these instances met overt hostility and antagonism from both the President and the audience (see El Universo, 2011:

http://www.eluniverso.com/2011/04/30/1/1355/asambleista-cesar-Montúfarrecibio-un-golpe-ojo-militante-alianza-pais.html). 


\section{Conclusion}

To conclude this section, it would be useful to ask, where does the line of the political end and where does it begin? Are Correismo and the Correista state fundamentally opposed to all non-state actors? Is the quieting of opposition indiscriminate? I would like to suggest here that one of the political fault lines for the Correista state lies, ironically, in containing and discouraging the political ideals set forth by the constitutional reforms of 2007-2008. I contend that one of the strategies of state formation under Correismo has been to extirpate politics from the realm of government - in the context of state formation in post-2008 Ecuador politics ends precisely where government begins. I also argue, that it is there that the exercise of power from governmental and pastoral forms adopts the form of disciplinary power (following in a broad sense Foucault's conception of 'discipline' (cf. Hindess 1996). Finally, I will contend that the thrust of disciplinary power is particularly directed at two social groupings: the indigenous movement embodied in CONAIE and social organizations critical of the extractivist model of economic development embraced by correismo. The next section deals with the issue of discipline in detail.

Finally, it is important to recall that depoliticization is never a final state (cf. $\mathrm{Li}$, 2007). It is not my argument that Correismo has been successful in depoliticizing Ecuadorian society or in destroying social organizations outside of the state. My objective is to make intelligible a form(s) of governmental rule that is itself an ongoing project. Clearly, it would be very difficult to completely demobilize and depoliticize social forces outside of the state. But, as Jacques Rancière puts it, the 
form of participation sought by the state seems to be wary of "persistent militant contestation" capable of "undermining the principles of good government ... the knowledge of experts, and the know-how of pragmatists" (Rancière, 2006: 7).

Image 6. "Management of Demands and Compromises from the Itinerant Cabinet" Form

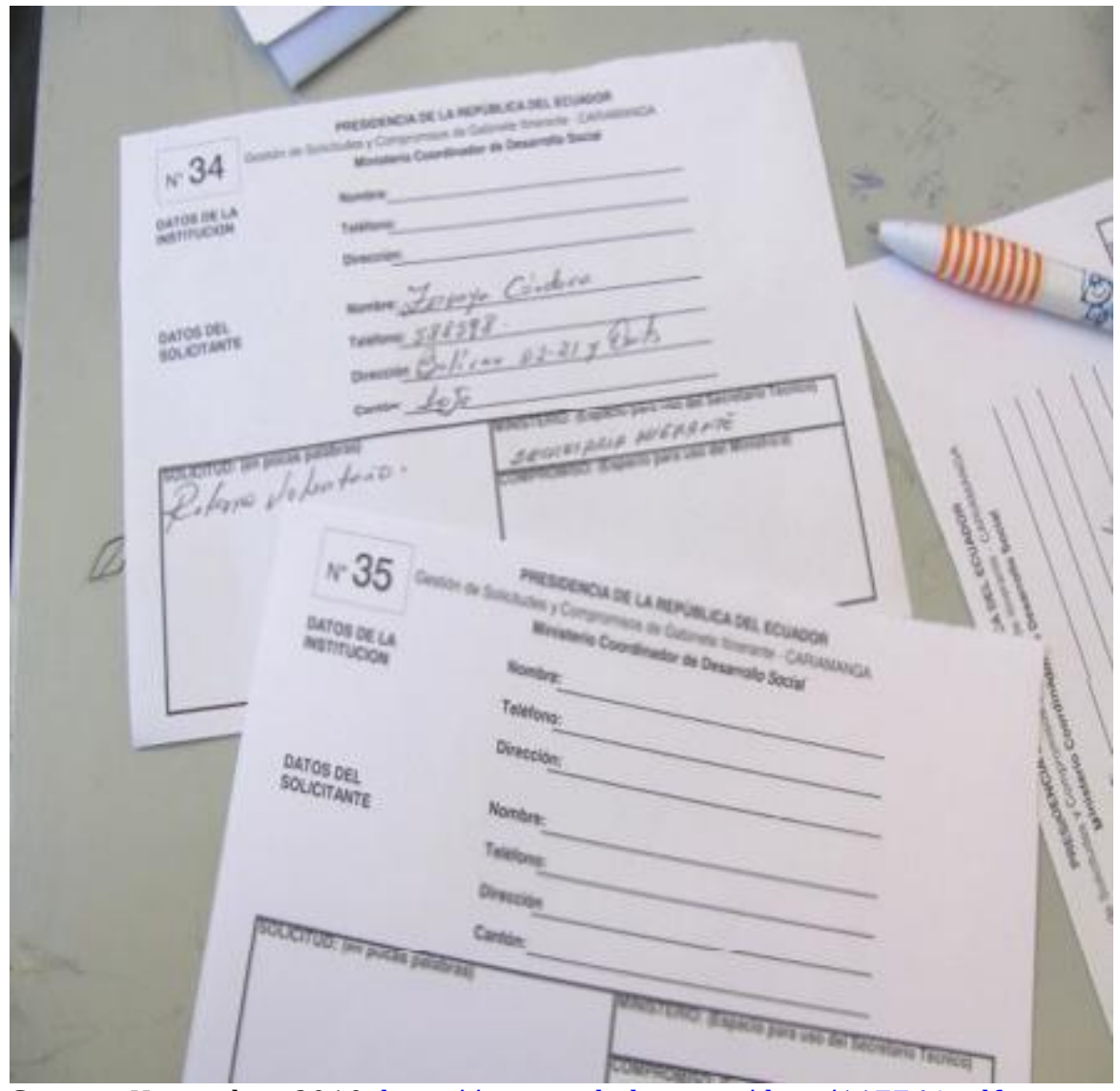

Source: Harnecker, 2010: http://www.rebelion.org/docs/117764.pdf

Militant contestation is defined here largely as opposition to the state's regime of improvement, particularly its extractivist policies (which, as mentioned earlier are seen as passages to improvement). It is not surprising, therefore, that participation as a project to be constructed is viewed by the state as a governmentalized, controlled, orderly activity. 
Thus, I would reiterate a central contention of this work: the post-2008 Ecuadorian state is not opposed to participation per se, it seeks to construct a form of participation (and thus a "participatory subject") whose spontaneous occurrence is contrary to "militant contestation." 


\section{CHAPTER SEVEN}

\section{STATE FORMATION AND THE GOVERNMENT OF PARTICIPATION THROUGH DISCIPLINE}

"Por encima de la retórica oficial, o de los contenidos constitucionales, los movimientos sociales enfrentan un permanente y peligroso proceso de devastación. El desmantelamiento de organizaciones populares, ONG, gremios, asociaciones, comités, etc. ocurrido en los últimos años, ya sea por cooptación o por asfixia, es obvio." -Juan Cuvi ${ }^{31}$

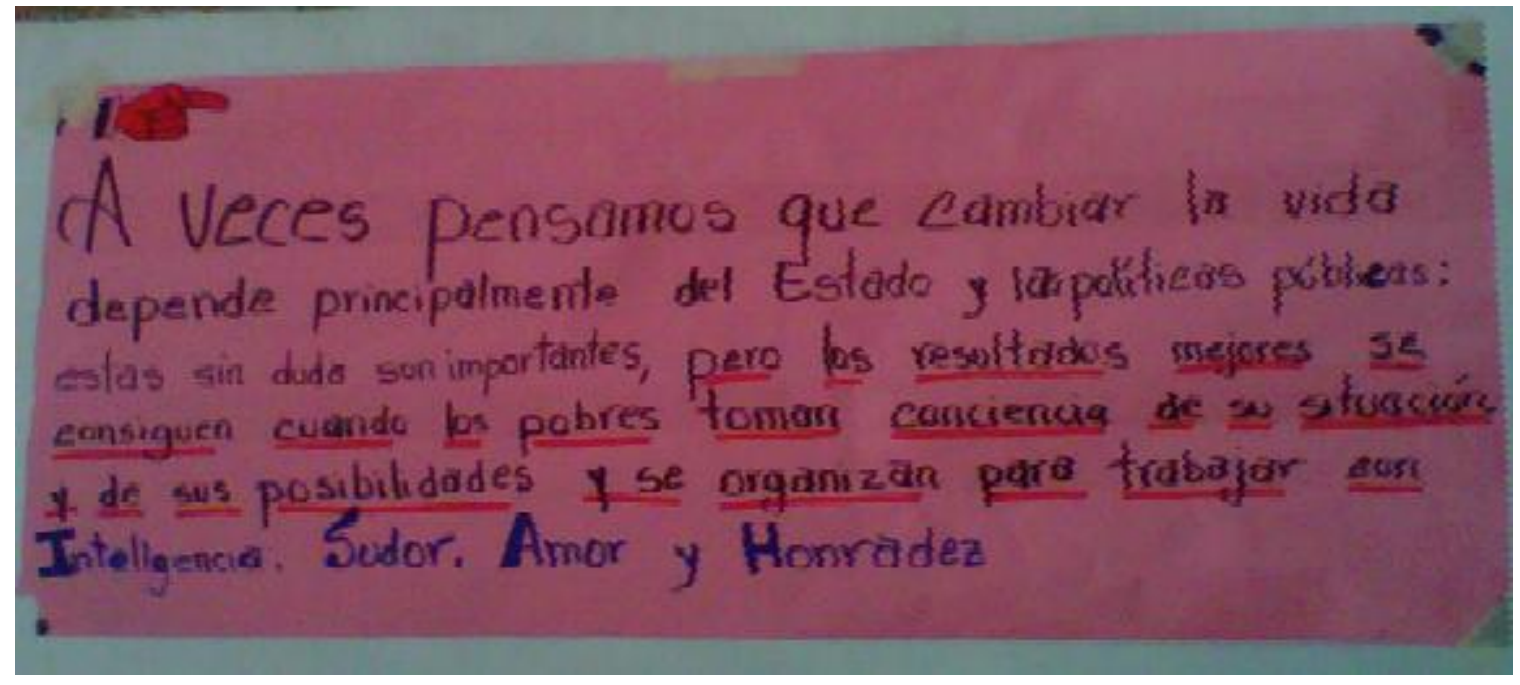

"At times we think that changing our lives depends mainly on the State and public policies: these are, undoubtedly important, but the best results are obtained when the poor become conscious of their own situation and their possibilities and become organized to work with Intelligence, Effort, Love and Honesty"

Source: Picture taken by the author from billboard in the offices of Acai, a small campesino organization in the Intag region, where the state is currently in the process of opening large-scale mining projects.

\subsection{Introduction}

\footnotetext{
${ }^{31}$ Source: El Comercio, 2013: http://elcomercio.com/juan_cuvi/opinion-juancuvi-participacionautonomia_0_1029497077.html
} 
Power and improvement are multidimensional and complex. Foucault has already located the "evolution" of power in different historical periods. Government often appeals, for its functioning, to various forms of power. Foucault did not make a sharp separation between governmental and disciplinary forms of power but argued that they are related and co-constitutive (Dean, 1999; Foucault, 2000). Informed by the theoretical emphasis on the inter-relationship between power and rule I ask the question about the role of disciplinary power in the constitution of government during the post-2008 state. In this chapter I argue that there is an important dimension played by disciplinary power in the formation of the state's regimes of government. In particular disciplinary power emerges precisely in the absence of proper political channels to deal with conflict when social forces are opposed to the regime of government fomented by the state. In the case of Ecuador, "improvement" as a regime of government (see Chapter Four) is clearly challenged by indigenous peoples' radical departure from certain modern apparatuses of interpretation and thought. This is most clearly seen in the opposition to the modernizing-developmentalism and its enabling practice, extractivism. Thus, the following chapter presents an analysis of disciplinary power,

its role in the constitution of the state and its government of social forces, particularly CONAIE.

\subsection{Protecting the Regime of Improvement}

I contend that a regime of improvement/development along governmentalized lines and defined under the premises of what could be termed 
modernizing-neodevelopmentalism characterizes the post 2007 state. Specifically, the post-2007 state is characterized not only by governmental power but also by what could be described, within a broad conception of the Foucauldian tradition, as disciplinary power. I approach discipline within a broad conception of Foucauldian power analytics for two reasons: First, because I am not departing from the idea that discipline acts directly upon the body, like it would in a classic Foucauldian formulation, like in a military barracks (see Foucault, 1995, 2000; Dean, 1999, 2010); I argue here that discipline can be a useful concept to understand how coercive forms of power are utilized to improve subjects who are deemed to be improvable. This is different from notions of sovereign power or straightforward authoritarian power in which coercion is applied independently of the status of subjects in relation to improvement and/or to subjects that are beyond the possibility of improvement: apartheid in South Africa is a clear example.

Second, I contend that disciplinary techniques in contemporary Ecuador are better understood within the context of the coloniality of power (see Castro Gomez, 2002; Mignolo, 2001, 2005; Sanjinez, Quijano, 2002). In Chapter Two I drew a link between decolonial theory (and the coloniality-of-power thesis) and Foucauldian power analytics and showed ways in which these two approaches can be usefully brought together analytically. Thus, the second sense in which I employ the term "discipline" is in the context of colonial relationships, something that Foucault ignored in his analysis of power (see for example, Alcoff, 1999).

A further analytical element to the disciplinary notion of power should be mentioned: the importance of the linkage between developmentalism and 
modernization. As is well known, the modernization ethos (cf. Echeverria, 2009) as well as economic modernization theories (e.g. Rustow, 1954) and modernization ideals about the state (cf. Evans, 1994; Weber, 2007) regard "tradition" as an obstacle to modernization. In this respect, as Cummings (1999) points out, the achievement of development is particularly well suited to Eurocentric cultures and ways of understanding progress. In other words, there is a direct correlation between improving in developmental terms and leaving behind traditionalism. Thus, what one would expect to see if developmentalism is a hegemonic force in Ecuador is, precisely, a confrontation between indigenous postulates regarding alternative forms of development rooted on indigenous cosmovisions and modernizing-developmentalism.

\subsection{Discipline, Indigenous peoples and the State}

I contend that disciplinary power, in a broad context, is an essential component in the construction of a modernizing-neodevelopmentalist regime of improvement since 2008. As mentioned in Chapter Two, discipline here is treated in a broader sense than in a "purely" Foucauldian fashion. While Foucault limited his analysis to discipline in the context of institutionalized practices in schools, prisons, clinics and factories, I broaden the concept to include non-institutionalized practices. Notwithstanding this difference two important similarities are kept: first, role played by surveillance in regimes of control and second, the importance of transforming subjects and subjectivities. In the cases presented below the central government's constant preoccupation and reactionary stance to indigenous 
expressions of dissent could be metaphorically understood as a form of surveillance. The various cases presented below suggest that part of the relationship between indigenous organizations and the government is defined by surveillance: the counter marches, the imprisonment of activists, the elimination of institutional autonomy, suggest, indeed, that indigenous peoples are indeed "being watched."

One of the important sources of debate regarding Asian developmentalist states, like the South Korean state for example is the positive correlation between authoritarianism and the consolidation of the developmental state model (WooCummings, 1999). In somewhat similar terms, I would like to posit that the particular characteristics of the contemporary Ecuadorian state, especially in what pertains to its stability, strength and consolidation, are in important ways rooted on the application of disciplinary techniques. What is particular about my claim is that the type of disciplinary and coercive power that is being utilized by the state since 2008 is not exercised in a widespread, indiscriminate fashion but as a way of protecting the stability of the state-led developmental project through a logic of improvement; that is to say, applying discipline as a way of improving subjects who are deemed problematic, "abnormal," and who in general lie at the margins of the regime of improvement but who are nonetheless considered capable of improvement - like indigenous peoples (cf. Hindess, 2002).

I should also reiterate that despite statements to the contrary (e.g. Ramirez, 2012), the state's conception and practice of "the political" is in important ways rooted on the liberal notion of the separation of spheres: there is a public sphere (embodied by the state, its institutions and state sanctioned organizations, like 
political movements and parties), which is the appropriate realm for politics and there is a private, or more broadly speaking, a civil-society sphere, which is the appropriate place for the "non-political." The corollary of this conceptual relationship is that the regime of improvement/development is determined by and within the state and in order to challenge it is necessary to enter into the institutionalized realm of politics, like participating (and winning) in elections. The link with disciplinary power lies in the job of the state as a legitimate political actor desiring to protect the regime of improvement from forces/actors, like CONAIE and other indigenous organizations, who should reside according to this logic outside the realm of politics/public sphere.

Finally, it would also be worth making a few points about the notion of surveillance mentioned earlier. What I suggest is that many of the acts of discipline mentioned here demand a corresponding system of surveillance for their operation, while others are forms of surveiollance in themselves. Counter marches, for example, because of the logistics implied in their organization require anticipation, preparation, and coordination. In other words, they are not spontaneous occurrences. For counter marches to take place a corresponding system of surveillance that keeps track of indigenous peoples' actions and mobilizations is needed. Similarly, the consistent and systematic engagement with indigenous populations through acts of discipline suggests that at some level indigenous organizations as are being surveilled. It is also important to stress that the institutional changes, particularly the enactment of Decree 16 and/or the restructuring of DINEIB and CODENPE are in themselves acts of surveillance. 
Decree 16 (see below), for instance, implies that the actions of independent civil society organizations, including indigenous peoples' organizations, are being observed, while civil society organizations cannot in return observe governmental actions (a classic "panopticon" formulation). To finalize, however, it would b worth stressing that my argument about discipline while concerned with the issue of surveillance is more directed at analyzing the question of subjectivities, normalization and the relationship between the regime of improvement set up by the government and indigenous peoples organizations, particularly CONAIE.

\subsection{The Emergence of Disciplinary Power: The two stages of indigenous movement-state relations}

The first Stage: 2006-2007

The first phase of indigenous peoples-government relations consisted, in part $^{32}$, in a critical political alliance between them (see for example, El Comercio, 2009a: http://www.elcomercio.com/noticias/CONAIE-anticipa-posturacritica_0_163185787.html). The broad political context at the time was characterized by the presence of an embryonic state project and AP's need to obtain political support from indigenous organizations in the absence of their own organic socio-political base (like that of Lula in Brazil and/or Morales in Bolivia) (cf. Spronk and Weber, 2007). In practice this meant a political compromise between CONAIE and Alianza Pais around the issue of a constituent assembly and the inclusion of the

\footnotetext{
${ }^{32}$ De la Torre (2010) argues that even during the Constituent process some of the original agreements to fully embrace SK at the expense of what I call here modernizing-developmentalism were evident. This, he argues, was the reason proSK Constituent Assembly President, Alberto Acosta was removed from the post.
} 
SK principles of plurinationality and interculturality into the new Constitution (Larrea, 2010).33

It should be noted that the successful incorporation of these principles sought, from the perspective of CONAIE at least, to overturn the very political and economic foundations upon which previous state forms had developed. Among other things, this implied ending models of development rooted in extractivism, that is to say, the intense and environmentally unfriendly extraction of natural resources like petroleum and minerals (Acosta, 2011; Macas, 2011; Radcliffe, 2012); it also meant securing some level of political autonomy for indigenous communities, particularly with respect to land/territory, education and water resources as well as a commitment to participatory democratic principles in the development of public policy by the state (Becker, 2011).

This is significant insofar as during the initial stages of the relationship between indigenous peoples and the government, a regime of improvement/development and regime of practices defining it had yet to be established; it also meant that the practical linkages between governmental forms and processes of state formation were still too incipient to acquire an intelligible form. Consequently, at the early stages of the Correista state the exercise of disciplinary power, as understood in this dissertation, was either not employed or employed only to a very limited degree. Arguably, the wider use of discipline begins in 2008 with the formal rupture between CONAIE (cf. Leon, 2011; cf. Opsina, 2012).

\footnotetext{
${ }^{33}$ It should be noted that the inclusion of plurinationality and other indigenous demands was a process partly characterized by internal disputes within the broader indigenous movement (Leon, 2011; El Comercio, 2008c: $\mathrm{http}: / / \mathrm{www}$.elcomercio.com/noticias/movimiento-indigena-dividido-plurinacionalidad-

Constitucion_0_164385074.html)
} 


\section{The Second Stage: 2008-2012}

The second stage of relations begins after the 2008 Constitution was drafted; once its principles had to be brought down to the level of specific governmental practices (cf. Lalander and Ospina, 2011; Larrea, 2011; Leon, 2011), that is to say, once the spaces for governmental intervention had to be constructed through concrete practices. It was during this stage, between 2008 and 2012 that disciplinary forms of power such as the ones discussed below begin to emerge as part of the modalities of power consistently exercised by the state. It is also at this time that a formal rupture between CONAIE and the Correa government took place $\begin{array}{llll}\text { (see for } & \text { example, } & \text { Ecuarunari, }\end{array}$ http://www.ecuarunari.org/es/nosotros/no_20080730.html).

The first large scale indigenous mobilization against the Correa government took place in 2008. The origins of the protest could be linked to various issues: the protection of state institutional privileges (i.e. autonomy over state-funded agencies DINEIB, and CODENPE), pressure to obtain constitutional mandates (like plurinationality) and opposition to extractivism (Zibechi, 2008). The 2008 protests were received with hostility by President Rafael Correa. In one of his weekly reports he stated, in reference to extractivism, that while indigenous communities may be consulted about the extraction of petroleum and minerals in their communities they may not, as a minority, stop the country from developing (WPR, 2010: \# 295). As I show below, these expressions are not an isolated case but a consistent strategy to confront indigenous peoples' opposition to certain aspects of developmentalism. 
Correa's expressions, furthermore, are better understood within a framework of discipline: indigenous subjects are expected improve in order to join the regime of improvement that defines the mentalities of rule in Ecuador.

\subsection{Exercising Disciplinary Power: A Discourse Analysis of Correa's Responses to Indigenous Protest between 2008-2012 from a historical perspective}

In 1990, during one of the largest and most significant indigenous protests in Ecuador's history, then president Rodrigo Borja Cevallos said in reference to the protestors:

Destabilizers who lack a conscientious sense of nationhood hope to divide the country by utilizing indigenous peoples from the highlands in a malignant way $[\ldots]$ we will outcast these irresponsible destabilizing individuals because no one has the right to disturb the peace and incite indigenous peoples and peasants to revolt [...] I want to remind peasants and indigenous peoples of the entire country that in 500 years, either in the republican or in the colonial epochs, no other government has done as much as my government to solve the problems of indigenous peoples [...] we have obliged everyone to treat them as human beings, as Ecuadorians, with the same rights and obligations (Borja, as cited in Guerrero, 2010: 100; first emphasis added; second emphasis in the original).

Despite important achievements of the indigenous movement since the time of Borja's speech, I show below that one of the ways in which Correista state punishes 
and disciplines indigenous peoples is through the same discriminatory and racist discursive strategies employed by Borja.

What I call the "second stage" of indigenous peoples' relationship to the government has also been characterized by a few instances of indigenous opposition, particularly, by the confrontation between CONAIE and the central government. To date the most numerous protests against the Correa government were carried out in March of 2010, when thousands of indigenous peoples congregated in Quito (according to major newspapers thirty-thousand; according to the government. ten-thousand). On the days preceding the indigenous protest, President Rafael Correa said: "We were the first against exploitation in this country. In any case, all of those who have been unable to defeat the Citizens' Revolution in five years are utilizing indigenous peoples and are convoking others to join their march through online social media" (WPR, 2010; emphasis added).

In an earlier speech about the same issue he said: "In order to avoid the 2013 elections [those who oppose our government] will try to do anything. They tried a revenge plan; now, it is sad - indigenous peoples, basically CONAIE, is being instrumentalized by the oligarchy..."

Subsequently, in what could be described as an overtly racist reference to indigenous peoples he noted: "certain owners of television channels no longer rule [Ecuador] ... No longer a few indigenous hoops [in reference to indigenous peoples' physical adornments] at the service of those in power, rule us" (WPR\# 258, 2012). Finally, Correa also said: 
How sad, how sad that certain indigenous leaders lend themselves to become instruments of their own exploiters, of those who always corrupted them, stepped over them, of those who never before included them in their newspapers, of those who would not let them into their houses, (sic) now the will appear on the cover pages, (sic) using them to hurt the government (Ibid.)

Guerrero presents a compelling interpretation of Borja's speech:

There are two sides to [Borja's speech]. On the one hand, indigenous peoples appear as naïve, childlike and simple, and as unable to fully reach adulthood given that they are always the object of 'malign' strategies of manipulation; left to their own devices they are passive beings stripped of their will and incapable of expressing themselves, let alone be in charge of their own defense. On the other hand, the speech draws a semblance of the dominant ones, the strategy of benevolence to one's inferiors ... the magnanimousness — noblesse oblige - of 'treating Indians as human.' (Guerrero, 2010: 101).

Guerrero's analysis of Borja's speech is particularly relevant. It reveals that, first of all, Correa's own words can be placed in a larger historical context. Correa's way of addressing indigenous populations, as "corruptible" and as Guerrero puts it, "childlike" is not new; and neither is his idea that left to their own devices indigenous peoples can become instruments of the powerful. References to indigenous peoples as childlike stem from a long tradition of racist discrimination and it has been the subject of various works of literature, most notably the classic 
novel by Jorge Icaza, Huasipungo (Icaza, 1939). In other words, Correa's statement can be attributable to a cultural discourse that has continuously been deployed within a system of colonial power relations.

Correa's discourse rests upon the notion that indigenous peoples are always in need of a translator, a ventriloquist and a father figure capable of speaking for them. By implication, Correa's discourse suggests that the indigenous protest of March 2010 was not really a protest, but the result of evil manipulation given that indigenous peoples, after all, are not able to mount their own defense or speak for themselves. The indigenous mobilization was not a legitimate expression of popular discontent since it represented the voices of the oligarchy. Thus, one is left with a rather unsettling proposition: Correa's view of the protests entails that there are two possible forms of indigenous expression, one given by the evil manipulation of Correa's political opponents; and a second one, the righteous and virtuous one given by Correa himself. In either case, as Guerrero would put it, indigenous peoples lack their own voice and the ability to speak for themselves.

Moreover, Guerrero's analysis of Borjas's speech reveals a further dimension of Correa's discourse, the improvable nature of indigenous populations. It reveals an aspect concerning the governmentality of correismo, which is coterminous with the new Ecuadorian state, namely the government of unfreedoms (Hindess, 2001; cf. Guerrero, 2010). This entails the use of discipline in order to govern populations who are not fully prepared to exercise their own autonomy but who are, nonetheless, capable of becoming autonomous in the future. In specific, practical 
terms, this could entail, as Barry Hindess puts it, restricting the freedoms granted by full citizenship to these populations.

Hindess shows that there are three possible forms of government of unfreedoms: the clearing away of those who lack the capacities for their own autonomy and freedom, that is to say, those who are deemed unfit for improvement; the disciplining of those who are not yet, but are potentially capable of fulfilling the requirements of their own autonomy and freedom (improvable populations); the provision of welfare benefits to those who for "external reasons" like poverty, health or inadequate education are not able to fulfill the requirements of their own autonomy (Hindess, 2001: 101). Correa's discourse in the face of indigenous protests makes evident the fact that, at some level, indigenous peoples are deemed apt for improvement but not fully ready for autonomy. In other words, organized indigenous populations ought to be governed under the second category.

There are various concrete examples of the governmental techniques that were used to this effect, before, during and after the 2010 protests. I have been able to detect at least four different ones: first indirect intimidation and delegitimization. The specific form of these techniques is the organization and promulgation of parallel counter protests and mobilizations; second, what could be termed a discursive war; this entails a consistent campaign to discredit organized indigenous resistance; third, direct acts upon the body of individuals; and finally, legal reform (cf. Bebbington and Humphreys, 2011). As I will show, all these techniques are in fact related and I would argue, could be grouped into a single disciplinary technology aimed at discouraging, controlling and reforming indigenous protest and 
reforming/improving indigenous subjects while protecting the stability of the state and its regime of improvement. Put differently there is an important dimension of the Correista state that seeks to discipline dissent.

\subsection{The Three Techniques of Disciplinary Government}

In this section I concentrate on the exercise of disciplinary actions through three main techniques: discursive disciplinary actions; intimidation and repression and legal/institutional disciplining. These techniques have been consistently employed against multiple social actors by the central government and have been well documented by several researchers and political commentators (see for example, Dosh and Kligerman, 2009; Becker, 2009; Ospina, 2009). Disciplinary actions have been particularly salient against civil society organizations that oppose extractivist policies and/or express overt opposition to Correa's leadership. Many of these cases involve the closure of and/or threats to several NGOs, particularly environmental ones. Notable examples include the recent closure of Pacchamama (environmental NGO); the closure in 2009 of Acción Ecológica (environmental NGO); the public denunciation and public intimidation carried out against NGO antimining activists in the Intag region during WPR \# 328 and 329 (2013); and the issuing of Presidential decree 16, which, as Cesar Montúfar indicates, severely limits the ability of NGOs to work independently of the state (Montúfar, 2013). Nonetheless and despite the importance of these cases, my focus here is on the relationship between indigenous peoples and the state. 
Below I show the explicit use of disciplinary techniques on indigenous peoples, especially on organized indigenous populations and particularly CONAIE. Prior to the 2010 protest, there were a few instances of confrontation between indigenous organizations and the state in which disciplinary acts were exercised by the state. Between 2008 and 2012 a series of indigenous protests took place. Most of these protests took place in the context of opposition to extractivist policies, loss of autonomy and political reform (Ospina and Lalander, 2012; Bebbington, 2011; Becker, 2011; Leon, 2011). In different instances and through different techniques organized protest has been met with acts of discipline.

\section{First: Rhetorical Disciplining}

The first, and perhaps most common disciplinary technique is an active discursive campaign aimed at discrediting indigenous peoples' political mobilizations critical of extractivism. I would like to posit here that one salient act of discursive violence relies on linking race to lack of progress. On this point it would be worth noting that disciplinary actions according to Foucauldian power analytics aim at the eventual transformation of subjectivities through a regime of surveillance inducing eventual self-discipline: at transforming the desires, wants, needs and general worldviews of people (also a discursive transformation). The techniques of discipline, as Foucault notes, may include long periods of shaming, regimes of physical training and "education," among others (Foucault, 2007; Dean, 1999). 
On the days prior to and following the March 2010 protest, President Correa devoted considerable space in his weekly reports to address the issue of indigenous peoples' opposition to mining and environmentalists' criticisms of his governments' extractivist policies. One of his forms of ridicule the protest and by the same token, indigenous opposition to mining, was to refer to the protest as "infantile" and "leftist," as a leftist protest of "feathers" and "ponchos" (traditional indigenous clothing) (WPR\# 258, 2010). Like his earlier reference to "hoops," the discursive association is clear: feathers, ponchos and hoops are equated with infantile positions and in allusion to indigenous peoples as a blockage development; feathers and ponchos are ridiculed and thus a component of the cultural identity of indigenous peoples is linked to infantilism and lack of progress. This amounts to a racist form of discipline. It is worth pointing out that my discursive interpretation of Correa's words is not arbitrary, besides its obvious signification, it is being interpreted within a historical context, one in which indigenous peoples, along with their cultural symbols have consistently been the object of racist ridicule and associated with backwardness and ignorance (see, for example, Walsh, 2009). In fact, Correa makes this plainly clear in one of his next sentences in the same weekly report when he said that while indigenous peoples are allowed to protest, they cannot “condemn Ecuadorian people to backwardness [retraso]" (WPR\# 280, 2012).

Racism in Latin America has long been a part of what I have defined here as disciplinary acts. Cristina Rojas's study of violence, race and representation in Colombia is a clear example (1998); so is Emma Cervone's study of Chagras in Ecuador (Cervone, 2010). According to Cervone, references to race in depreciatory 
terms serves as a discursive tool for some Ecuadorians to distance themselves from their indigenous roots and by the same token prompt changes in the subjectivity of those who are still close to their indigenous roots. Similar results were produced by Karim Roitman's study of young middle class students in Quito and Guayaquil. Specifically, Roitman discusses how the use of certain racist terms like "longo" or "cholo" serves as a disciplinary tool insofar as its use is not only a way of denigrating others but as a disciplinary act of the self: racism towards others is racism towards oneself. Roitman's argument suggests that as young people from Quito and Guayaquil employ terminology like "longo" or "cholo" they are really working to transform their own subjectivities in order to distance themselves from longo or cholo, and clearly, to become less indigenous. Ecuadorian authors like Eduardo Kingman (2009) and Jorge Enrique Adoum (1998) have reached similar conclusions.

It is also fundamental to mention that race in Ecuador has generally been directly linked to civilizatory projects (cf. Rojas, 2002; Walsh, 2009; Guerrero, 2010). Race, as Kim Clark shows in her study of Ecuadorian census history, was a signifier of backwardness and/or progress: white-mestizo Ecuadorians were linked to progress while indigenous peoples or blacks were linked to backwardness (Clark, 1998). In view of the important amount of evidence in this respect one's interpretation of Correa's discursive strategies against indigenous opposition cannot be divorced from the historicity of the racism-civilizatory projects, racismdevelopment linkages in Ecuador. 
I should also say that from a Foucauldian perspective references to race in civilizatory terms could be understood as acts of normalization. For Foucauldian power analytics acts of discipline are acts of normalization. In this sense one could argue that denigrating indigenous peoples for not joining a developmentalist regime of improvement seeks to normalize non-indigenous subjects according to the standards mentioned earlier, thus rendering opposition to the government's understanding of progress and "development," and thus some indigenous groups, as "abnormal." In an empirical sense the thrust towards normalization is plainly visible in the form of rule based on plebiscitary democracy. Politics, power and truth are clearly linked to the will of the majority. As Correa himself put it: "those who obtained only $2 \%$ of the vote [in reference to the indigenous movement] cannot tell the majority what to do [in reference to extractivism and a change in mining policies in particular]" (El Comercio, 2009: http://www.elcomercio.com/noticias/Correaprotesta-CONAIE-desconoce-Ley_0_6600054.html). In sum, racism is a disciplinary discourse-practice directed at normalizing the $2 \%$ in the image of the $98 \%$ - at least insofar as accepting the government's regime of development goes (of course the image of the $98 \%$ is determined by power practices in which the government plays a fundamental role).

In similar fashion in 2008 , facing one of the first waves of opposition to mining policies from indigenous peoples and environmentalists Correa said:

Unfortunately, some people are 'childish'--in quotations--like the ones opposed to mining. But what country in the world has rejected mining? The dilemma is not 'no' or 'yes' to mining. It is well-developed mining. 
There is simply no dilemma ... [The childish environmentalists] believe that bringing an end to an extractive economy is to shut down the oil wells and close the mines. That is absurd. Getting out of that economy means using this sector's surplus to revive other sectors of the economy: services, agriculture, industries, etc. (Correa as cited in Dosh and Kligerman, 2009: 1).

In 2009 after another wave of indigenous protest, Correa said ${ }^{34}$ : "enough impunity in this country, we will be alert to sanction those people who think that can hit, through rocks, attack, be aggressive, just (sic) to later say that the public force [the police] committed abuses [against them] (El Comercio, 2009: http://www.elcomercio.com/noticias/Correa-protesta-CONAIE-desconoceLey_0_6600054.html.

In addition to the racially charged overtones of Correa's discourse, these two additional examples represent other forms of disciplinary discourse, I would argue, for two reasons. First, implicated in them is the potential for reprisals and punishment. This is clearly a disciplinary act in that what is being sought is the regulation of behaviour of protesters in favour of the idea that mining is good for development through the threat of punishment. At the same time, the idea of childlike behaviour returns in a somewhat different form. In this particular discursive passage the childlike behaviour is linked to opposition to development itself, not necessarily to external manipulation. This discursive stance relies on the

\footnotetext{
${ }^{34}$ While in this particular assertion president Correa did not allude specifically to indigenous peoples, his comments were made specifically in the context of indigenous protests.
} 
notion that indigenous peoples are in a position of exteriority with respect to sound knowledge about development and progress. As mentioned earlier, part of my argument in this work is precisely that discipline is used to defend a regime of improvement from "childlike" actors whose opposition to a regime of improvement is not only a result of manipulation, but, as I have showed here, epistemologically unsound.

\section{Second: Intimidation and Actions on the Body}

In 2010 in the days preceding indigenous mobilizations Correa began to construct the rationale for a counter-protest. The disciplinary content in Correa's discourse is evident. In his weekly report number 259, on February 25, 2010, Correa argued that the protest represents a serious danger to the achievements of his regime; in this sense the success of the indigenous march and what it represents, may entail, as Correa put it, "reverting the Constitutional order, a return to the past and the loss of all that has been conquered [by his regime]" (Weekly Report, 2010: \#259). The solution he proposes is to have an organized, mobilized and active "social base" capable of defending the government. This is a recurrent idea in the weekly interventions leading to the indigenous march.

As part of my research on state formation I went to the site of the march. On March 20, 2010, I spent much of the day taking notes listening to speeches and speaking with participants. My interest was twofold: first to understand, on the ground, the "power effects" of state responses to an indigenous people's

mobilization. Second, I aimed to capture some of the reactions of self-identified 
members of indigenous peoples to those strategies. The day of the protest, as I followed indigenous protestors down the streets of Quito, two things became clear: First, that the response by the state to indigenous peoples mobilizing was a war-like logic of confrontation through numbers. Specifically, the strategy consisted in organizing a larger counter protest that would take place at the same time and in the general vicinity of the indigenous protest. Second, that the strategy undertaken by the government did not prevent indigenous peoples from protesting and engaging in such a clear political act, but it did create apprehension and concern.

During the march there were multiple conversations between participants about the potential dangers of the march. I would say that chief among them was the presence of the pro-government counter protest. Concern on the streets was echoed by news reports: as I stopped at a local corner store during the march one could hear news reports about the danger of pro-government and opposing forces meeting on the streets as well as Correa's effervescent speeches decrying the indigenous march (field notes, March 20 $0^{\text {th }}, 2010$ ). According to Correa himself, the government's counter march brought together at least 30.000 people (WPR\# 300, 2010).

While no actual violence took place, it became palpably clear that a counterdemonstration was an act of discipline in the sense that, like in the case of discursive violence, intimidation and the threat of confrontation were used in the hope of transforming and controlling the protest and its potential multiplier effect. Moreover, the counter-protest set a precedent about the difficulties and potential problems that an indigenous mobilization could bring. Like in the case of discursive 
violence it worked to discredit indigenous mobilizations by portraying indigenous populations as a disruptive minority whose support for development is showed to be lacking. I must also emphasize that a counter-demonstration and the discourse around it divided populations into two different kinds: those in favour of development, the majority of the population characterized by their "mature" behaviour, and those who are against development as a result of manipulation. Needless to say, this form of classification mirrors older forms of segregation with new faces.

It can be argued, therefore, that as far as indigenous peoples are concerned participation and mobilization count as such as long as they do not question the state's regime of improvement. One of the reasons for arriving at this conclusion is that indigenous mobilizations do not count, according to governmental discourse as genuine expressions of indigenous discontent, but, as mentioned before, the result of manipulation by the oligarchy. Take for instance another statement made about the protest by Correa:

The de facto powers are weakened but alive - [they] are organized. They are already organizing the march of March $8^{\text {th }}$, utilizing the comparers from CONAIE, as always, but financed by the Chamber of Commerce of Quito, the Junta Civica from Guayaquil, and hotel entrepreneurs from Guayaquil (WPR\# 259, 2010)

In sum, indigenous peoples' voices during the march were almost by definition "deviant" or "abnormal" since it is not really their voices that emanated from the 
March protest, but the interests and will of the Chamber of Commerce, the Junta Civica and so on.

It should also be noted that the approach to politics mentioned in Chapter Two discloses one important dimension of politics: dissension and agonisms. Mouffe makes an important distinction between antagonisms among warring parties and agonisms between political adversaries. Similarly Ranciére, as mentioned in an earlier chapter, makes a crucial distinction between logic of police and politics. The examples shown so far would suggest, at first glance, a highly politicized environment in Ecuador. That would be the case, however, if politics were regarded as a war-like activity, not as that which allows for the emergence of difference through the disruption of "police." In this sense through Rancière's view of politics it becomes clear how the appropriation by the state of the narratives of Sumak Kawsay and their association by the state to developmentalist narratives, strips Sumak Kawsay of its disruptive potential and, therefore, de-politicizes it.

Similarly, from the perspective of Mouffe's analytics, political adversaries are not the same as warring enemies. In counter-marches for example, politics is supressed insofar as the two sides in the dispute cannot meet in as political adversaries where political subjectivities (diverse political discourses and practices) can be fleshed out. In the marches of 2010, armed police had to separate indigenous peoples form the groups supporting Correa. There is, in this sense a clear antipolitical machine at work seeking to displace politics from spaces where the government's regime of improvement is challenged. It is important to note that this 
is not only a question of supressing dissent but another component of a larger antipolitics stance that defines the governmental ethos of the state.

\section{Actions on the Body}

Other instances, besides the March 2010 protest, are also worth mentioning. In fact, the disciplinary attitude towards many indigenous groups has been systematic since 2008. Disciplinary action has been perhaps most visible in the fight against extractivism. As far as the argument of my work is concerned this comes as no surprise. Mining is, partly, as the President of the Republic notes, "Ecuador's way into development." Why, the President has asked, "should Ecuador sit atop a mine of gold [and not use it]?" (Dosh and Kligerman, 2009: 23). Thus, the extraction of natural resources is viewed as being great of importance for the state, its construction and consolidation.

One of the first instances of disciplinary actions came in the confrontation between the state and indigenous peoples over two laws of mineral and hydraulic resources initially discussed in Parliament in 2009. The mining law and the water laws have been two of the most polemical laws from the perspective of indigenous populations. Between 2008 and 2009 the state and indigenous peoples, mainly CONAIE, began a highly conflictive relationship over the content and passing of these laws. Paul Dosh and Nicole Kligerman (2009) documented this relationship between 2008 and 2009. As Dosh and Kligerman show, the response by the state to indigenous opposition to the mining law has been, in many instances, outright repression (Dosh and Kligerman, 2009). 
A common method utilized in the disciplinary dimension of state power has been the employment of the justice system and police power to dissolve, discourage and suppress popular protest. There are many accounts of this phenomenon. This year, for instance, two indigenous activists were convicted and imprisoned for what had originally been accusations of terrorism. ${ }^{35}$ The trial originated in a protest carried out to defend water rights in indigenous communities in the South of Ecuador (Hoy, March 25th 2013). In 2012 Universidad Andina Simon Bolivar released its annual Human Rights Report (UASB, 2011; see also Hoy, 2009: http://www.hoy.com.ec/noticias-ecuador/indigenas-acusados-de-terrorismo406420.html) documenting over two-hundred cases of indigenous leaders and other popular organizations' leaders and NGO representatives accused of terrorism, sabotage and/or as being threats to the security of the state. Similar reports have been echoed by international press sources (see Al Jazeera, 14 February, 2013). In at least two instances, these accusations have led to hefty prison sentences: Pepe Acacho and Pedro Mashiant, indigenous activists and organizers of a 2009 protest against the government's "Water Laws," were recently sentenced to twelve years in prison (Hoy, 2013: http://www.hoy.com.ec/noticias-ecuador/pepe-acacho-fuesentenciado-a-12-anos-de-prision-588234.html).

\section{Third: Institutional Disciplining, the case of DINEIB and CODENPE}

It would be useful to begin this section with a theoretical note about discipline and institutional reforms. Discipline by decree would normally be associated with

${ }^{35}$ Later the counts of terrorism and sabotage were dropped. The protesters were nonetheless jailed but on counts of interrupting public services. 
Foucault's notion of sovereign power, not with discipline. I argue, however, that the disciplinary dimension of the reforms presented below rests beyond the application of a law or the actual institutional transformation of DINEIB and CODENPE. The reforms can be interpreted as a one in a series of actions that seek to define normal behaviour - the normalization of behaviour according to the developmental needs of the regime of improvement established by the government. In this respect, it is also important to stress that this particular section on "institutional disciplining" ought to be read alongside and in complement to the other disciplinary techniques discussed in this chapter.

During the late 1980s and 1990s, indigenous uprisings were a significant aspect of Ecuadorian political and institutional life (see Selverston-Cher, 2001). The process of change unleashed by indigenous peoples' mobilizations during the 1990s brought about a number of important legal/institutional victories for organized indigenous populations. In particular, the creation of a set of indigenous institutions and organizations that reflected some of the principles of political autonomy associated with the development of a plurinational state. The two most important (largest and far-reaching) of these institutions were the National Directorate of Bilingual Intercultural Education and Intercultural Education of Ecuador (DINEIB) created in 1988 and the Council for the Development of the Peoples and Nationalities of Ecuador (CODENPE) in $1998 .{ }^{36}$ Reforms also included the creation the Fund for the Development of indigenous Peoples (FODEPI) and of the National

\footnotetext{
${ }^{36}$ CODENPE's institutional history begins with the creation of its early predecessor, the "National Secretariat for Indigenous Affairs and Ethnic Minorities" (SENAIME) in 1994 (CODENPE, 2013: http://www.codenpe.gob.ec/index.php?option=com_content\&view=article\&id=165\&Itemid=677).
} 
Directorate of Indigenous Health. It should also be noted that DINEIB and CODNEPE (see footnote 19) were the first autonomous indigenous organizations of their kind in Ecuador's history. However, between 2009 and 2010 the entire apparatus of indigenous peoples' autonomous institutions was legally reformed and placed under the tutorship of various ministries and ordained through a vertical governance structure whose fulcrum is the Executive Branch (Ospina, 2010).

\section{DINEIB and CODENPE: Autonomous, Formal Indigenous Institutions}

DINEIB, perhaps the most emblematic of the organizations mentioned above (for its longevity and the importance of education in processes of decolonization) was created as an autonomous organization in charge of indigenous education policy-making. DINEIB comes as the result of the "educational experience amassed in indigenous contexts in Ecuador in recent decades ... and of the legal action, social mobilization and ongoing struggle conducted in the country by the indigenous movement" (Torres: 2006: 24). DINEIB was created as entity within the National Ministry of Education (it was, technically, a public institution) responsible for the "development of an appropriate curriculum for each of the systems and modalities of bilingual intercultural education, and for the design of educational modalities consonant with the needs of the [indigenous] population" (Ibid.). Even though DINEIB operated as part of the national educational system, it had financial, operational/administrative and political autonomy from the central government. This meant that DINEIB received funds directly from the state's general budget and 
that its policies, programs and projects were decided internally by representatives of indigenous peoples.

On the other hand the Council for the Development of Peoples and Nationalities of Ecuador (CODENPE), was created through a related but somewhat different process. CODENPE emerges, like DIENIB, following a period of political crisis. The 1990s was perhaps the decade in which the Ecuadorian indigenous movement was most vocal, cohesive and politicized (see for instance, Sawyer, 2004; Yashar, 1999). CODENPE was created during the Constitutional Assembly of 1998. The creation of CODENPE granted institutional autonomy to indigenous populations in the management (gestation) and generation of their own "developmental" $\begin{array}{llll}\text { policies and 2013: } & \text { (Codenpe, }\end{array}$ http://www.codenpe.gob.ec/index.php?option=com_content\&view=article\&id=161 \&Itemid=465). CODENPE's website describes its mission as being that of a:

A public institution, which in the exercise of rights within a plurinational state, executes policies to strengthen indigenous peoples [pueblos] and nationalities, intercultural living and the promotion of life-plans, and the contribution to a balanced relation with Pachamama [mother earth] and the reaching of Sumak Kawsay/Buen Vivir (CODENPE, 2013: http://www.codenpe.gob.ec/index.php?option=com_content\&view=artic le\&id=164\&Itemid=676).

In sum, the institutional autonomy of CODENPE, like DINEIB's, meant financial independence from the central government and (at least in legal terms), the ability to design and implement "development" policies within indigenous communities 
and political independence from the state. And as Carmen Martinez-Novo (2013) states, autonomy also had other practical benefits such as increased employment opportunities for young indigenous professionals.

Before analyzing the fate of these institutions in the post-2008 state, I should note that in contrast to the ideal of "autonomy" defended by (neo)liberalism, the demand for indigenous autonomous institutions is largely rooted in the principles of collective rights and identities (Anonymous Interview, 2012) and harboured in an ongoing process of decolonization (Ibid.). The political success of the indigenous movement during the 1990s responded, to a large extent, to the success of its collective understanding of organization (i.e. how to organize) and the mobilizing force of CONAIE, its largest organization. It is also important to emphasize the deeply political nature of these struggles and the importance that popular participation had in them. In this sense, the creation of DINEIB and CODENPE, notwithstanding its policy objectives, was always a political, rather than a technocratic or bureaucratic accomplishment (cf. Walsh, 2010; Torres, 2006).

Precisely, one of the most important and salient characteristics of both DINEIB's and CODENPE's governance structures was their participatory nature. Both institutions were governed through a system of participatory representation in governing councils of "peoples and nationalities." These governing councils represented most of the self-defined indigenous "nationalities" and peoples (pueblos) through a system of first (grass roots), second (regional organizations) and third degree organizations (national organizations) as well as representatives from indigenous communities themselves. I interviewed an indigenous educational 
leader who was active in the process of constitution of DINEIB and who is now an important member of Ecuarunari's department of education and he described the selection process of DINEIB's governing structure as a collective process based on large grass-roots assemblies (Anonymous Interview, Quito, November 21st, 2012). This meant that the governmental structure of these institutions was representative not only of indigenous communities but also had direct ties to the most important indigenous organizations in the country, particularly CONAIE but also FEINE and FENOCIN. Put differently, and as stated earlier, the creation of DINEIB and CODENPE was from its early historical roots to its internal organization, an eminently political process rooted in a politicized indigenous movement.

Considering the points mentioned earlier in this chapter regarding the use of discipline and de-politicization as a state "ethos," it becomes crucial to ask about the relationship between indigenous autonomous institutions embodied in DINEIB and CODENEPE and the post-2008 state project. What characterizes this relationship? I answer this question by arguing that one of its defining elements has been the use of disciplinary measures to eliminate the autonomy of indigenous populations and the influence of CONAIE in their internal structures. This argument, I should emphasize, does not entail that its opposition to indigenous peoples fundamentally characterizes the post-2008 state, rather that its strategic positioning relative to participation (see previous chapter) is partly rooted in guarding its regime of improvement/development. In practice this has meant, incorporating of both DINEIB and CODENPE into a vertical governance structure that without excluding indigenous peoples, eliminates their political and financial autonomy and the 
influence of indigenous peoples' organizations in their internal affairs. To tackle this issue, I now turn to the state narratives regarding autonomy and politics as applied to the cases of DINEIB and CODENPE and the posterior use of disciplinary measures to abolish indigenous institutional autonomy.

\section{The Loss of Autonomy of DINEIB and CODENPE}

Between 2009 and 2010 both institutions lost their autonomy and were fully incorporated into the structure of the Executive Branch. In 2009 President Correa signed Decree 1585, which was later modified by Decree number 196 in 2010, placing DINEIB under the full tutelage of the Ministry of Education; similarly in early 2009 the President emitted a decree cutting CODENPE's budget. Both instances had significant political consequences for both institutions. In the case of CODENPE, the President's actions resulted in the resignation of CODENPE's Secretary General, Lourdes Tiban, a well-known indigenous leader and activist associated with CONAIE (see, El Comercio, 2009c: http://elcomercio.com/noticias/Codenpe-quedapresupuesto_0_6600494.html; SERVINDI, 2009d:

http://servindi.org/actualidad/6977; $\quad$ El 2009: http://www.telegrafo.com.ec/actualidad/noticia/archive/actualidad/2009/01/22/ Tib_E100_n-renuncia-al-Codempe-.aspx).

In the case of DINEIB, following the enactment of decrees 1585 and 196, officials within the Ministry of Education and the Council of Participation and Social Control were put in charge of the most important roles in the selection process of DINEIB officials (Presidency of Ecuador, 2009: Decree 196; available at: 
http://decretos.cege.gob.ec/decretos/decretos.aspx?id=2009). Decree 196 also establishes the factors determining the eligibility for the elections of DINEIB directorate. Two important elements are worth mentioning here. Points " $b$ " and "d" of the decree are directly linked to social protest and indigenous organizations: point "b," for instance, states that those who have presided the intercultural bilingual system more than twice will not be eligible to do it again; point $d$, states that those who have participated in "paralyzing" the educational system illegally, are not eligible to become part of the internal leadership structure of DINEIB. In both cases the reference to social protests are clear, albeit indirect.

Point $d$ on the other hand, appears to have particular significance or be particularly relevant for the former leadership of the general bilingual education system, particularly to CONAIE cadres. It must be remembered that all the leaders of DINEIB prior to the 2009 reform had been associated with the major indigenous organizations in the country, particularly CONAIE; in addition, there are no leaders that fit the description made in point $d$ that were not associated with CONAIE or one of its affiliates. In other words, point $d$ in decree 196 limits the degree of future influence of CONAIE cadres. Other authors have also noted this particular point. Carmen Martinez-Novo (2010: 17) contends that:

It is clear that what these stipulations are seeking is to exclude the established leadership of the indigenous movement who have already held high positions and who have challenged the government in demonstrations and strikes. The government seems to be seeking to promote new people, closer to the grassroots and more faithful to its 
project.

A point that is worth stressing about this process is the "open war" against politics outside of the state - or outside its direct control. Politics is defined as being fundamentally inimical to the act of government as a technical activity. The case of DINEIB clearly shows how politics is automatically defined in opposition to technical issues: there are issues, like good education for example, that are beyond the realm of political argumentation, discussion or the intervention of organized indigenous groups. The transformation of DINEIB into a "technical" institution entails, thus, limiting the influence of CONAIE and the indigenous movement in its internal governance structure and policy generating departments. But the idea of politics and government as a technical issue goes further: it seeks to erase from the educational texts and the educational experience of indigenous peoples the series of recent struggles that the indigenous movement, particularly CONAIE, has faced.

A point worth stressing is that the case of DINEIB and CODENPE, specifically the forced loss of autonomy to which they were subjected demonstrates some of the ways in which legal mechanisms are applied in a disciplinary fashion. The notion that the state is the only legitimate arena for political participation is made visible by the disciplinary design and implementation of decrees 1585 and $196 . \quad$ The application of these decrees also makes visible the disciplinary logic behind the process of state construction: indigenous peoples are not denied participation altogether like in the hacienda state; neither are they made invisible and relegated to the position of non-citizens like in the neoliberal state. Discipline entails the possibility of "improvement." In the case of DINEIB or CODENPE, the state does not 
seek to eliminate indigenous peoples' presence as such; in fact all of the directors of both institutions since 2009 have been indigenous. Discipline implies the possibility of improvement through periods of correction, training and/or punishment. In other words, indigenous peoples continue to work and be active agents within DINEIB, but their participation is stripped of its political content and relegated to a technocratic understanding of participation in the state.

\section{Loss of Autonomy and Depoliticization}

The emphasis on transforming DINEIB into a technical institution was clearly reflected in an interview I conducted with an indigenous top-official at DINEIB. In the interview I inquired about the implications of DINEIB's loss of autonomy. Most of his replies pointed to the "fact" that DINEIB's rather mediocre educational results over the past twenty years needed to be corrected through technical measures, not political ones. He blamed politics embodied in the intervention of indigenous organizations in DINEIB for these results. He indicated that "professionals without experience" entered the system and the intervention of indigenous organizations resulted in a "lack of improvement in the quality of education" (Anonymous Interview, Quito, December 10 $10^{\text {th }}, 2012$ ). Moreover, he stated that DINEIB and the people in it (placed there by indigenous organizations, like CONAIE were always active in their opposition to the different governments of the state. He saw this as a problem and as part of the reason that DINEIB needed to be transformed into a technical, not a political organization.

However, the idea of politicization measured as a function of poor quality can 
hardly be an indicator of CONAIE's influence on the bilingual indigenous educational system. As Pablo Ospina (2010:33) notes in reference to this very point:

there are structural problems in rural education in the entire country: bilingual education is as bad as regular rural education and is perhaps a little bit better. For twenty years, during the reign of neoliberalism, the DINEIB suffered the same postponement as all other social policies.

In other words, the quest to de-politicize DINEIB must be understood beyond the notion of poor educational standards and considering the fact that for the last twenty years, the entire educational system, not only the system managed by DINEIB, has been in crisis. The decree reforming DINEIB suggests that the basic premise behind the reform is to eliminate politics understood as CONAIE's influence and participation in educational policy-making within DINEIB - independently of DINEIB's performance as an educational institution. Moreover, and as the official I interviewed indicated, participation of indigenous populations in the establishment of educational policies should be at the technical level (Anonymous Interview, Quito, December $\left.10^{\text {th }}, 2012\right)$. He was unambiguous about stating that the efficiency of the state (as far as intercultural, bilingual education is concerned) is a fundamental premise in the process of restructuration that DINEIB experienced. Eliminating politics and restricting indigenous peoples' participation to its governmentalized form (i.e. indigenous peoples participating as "technicians") is correlative to recuperating the technical capacities of the state and intercultural education.

In reforming DINEIB and CODENPE the state was clear about its attitude towards political indigenous activism: politics means not only the influence of 
indigenous organizations in DINEIB and CODENEPE but limiting the technical capacity of these organizations. According to the Ministry of Education, a proof of the political nature of DINEIB's work is that "Its texts references were made to the work of Ecuarunari and CONAIE" (El Comercio, 2009a: http://www.elcomercio.com/noticias/Dineib-sacudida-Decreto_0_7199814.html) and also to the fact that "seventh-grade educational texts elaborated by DINEIB made references to the indigenous mobilizations of the previous decade and a half (Monteluisa, 2009). The idea of a politicized indigenous educational system has been used, as Walsh notes, "to discredit indigenous organizations and take away their power (earned through struggle) to define their own educational processes" (Walsh, 2010: 9); in other words, as a disciplinary measure against indigenous peoples' politicized autonomy.

The loss of autonomy in DINEIB and CODENPE can be understood, thus, in a broader context of disciplinary actions aimed not only at correcting the actions of indigenous organizations like CONAIE, but to do it as part of a larger depoliticizing governmental power resource. In 2009 the Ministry of Education released the following statement in reference to the changes in DINEIB:

Ecuador's public education must be free of all corporatist influence, be it from political movements, professional associations, ethnic organizations of various kinds that claim to represent of groups of society [...] In this way DINEIB will stop acting in isolation and will stop responding to the political interests of an elite of indigenous leaders, that will no longer be able to, under the old system, impose authorities or racist and blind 
political ideas, or utilize educational spaces for their processes of indoctrination" (Ministry of Education of Ecuador, as cited in Walsh, 2010: 87).

Newspapers at the time also reported that for the Ministry of Education DINEIB needed to be reformed given that its actions "were permeated by a political trace" (El Comercio, 2009a: http://www.elcomercio.com/noticias/Dineib-sacudidaDecreto_0_7199814.html) and that indigenous leadership should not be in charge of designating the directors of the DINEIB, instead the directors of the DINEIB should adhere to the professionalizing and meritocratic logic of state modernization (Ibid.). In doing so the government hoped that DINEIB would no longer act in "an isolated fashion responding to political interests" (El Comercio, 2009b: http://elcomercio.com/noticias/Remezon-escuela-bilingue_0_7799565.html).

Similarly, just a few weeks prior to the state's intervention at DINEIB President Correa announced the withdrawal of funding for CODENPE arguing that the organization has been a source of "political spoils" for the benefit of a "certain $\begin{array}{lllll}\text { indigenous } & \text { leadership" } & \text { (El } & \text { Ciudadano, } & \text { 2009: }\end{array}$ http://presidencia.informatica.gob.ec/index.php?option=com_content\&view= article\&id=103:gobierno-pide-auditoria-para-elcodenpe\&catid=2: politica\&Itemid=43). Likewise, Ariruma Kowii, director of DINEIB following the reforms, justified state intervention by alluding to "a few cases of nepotism" and the creation of bureaucratic posts that responded to "political pressures" rather than "technical criteria" (El Comercio, 2009: http://www.elcomercio.com/noticias/Remezon-escuela-bilingue_0_7799565.html). 
These statements are not isolated but part of a broader discourse that irrevocably divorces politics from "improvement" and establishes the state as the central engine of improvement, regarding challenges to that conception with suspicion. An important definitional aspect of "discourse" is that in discourses are embedded the limits of how an issue is discussed and according to which principles of interpretation discussions about it should be carried out (cf. Foucault, 1972; cf. Rojas, 1998). It should be noted that the strategic weight of the state in defining the terms of such a discursive regime is important but the force of a strong discourse cannot be reduced to a single point of enunciation or to the role of any one single (powerful) actor. A survey of the discussions that preceded and ensued from the legal reforms of DINEIB, for example, reveals that the issue of politics was rarely discussed outside the interpretations mentioned above.

Perhaps the best way of illustrating this point is by pointing not to the narratives of governmental agents but to those of indigenous leaders themselves . For example, Delfin Tenesaca, President of Ecuarunari in 2009, responded to the decree by alluding to the loss of autonomy of DINEIB but also to what he considered the intention of the government to "politicize DINEIB" by placing people from Correa's party in DINEIB (Hoy, 2009: http://www.hoy.com.ec/noticiasecuador/educacion-bilingue-se-torna-asunto-politico-386674.html). Similarly, in an official communiqué signed by Dr. Luis Montaluisa, national director of DINEIB, as well as other indigenous leaders at the time, indigenous peoples expressed their concerned for what they considered a "politicized intervention" [sic] of the regime in DINEIB (Servindi, 2009: http://servindi.org/actualidad/7997). 
In this sense it is important to mention that a central theoretical factor in the unfolding of governmental processes is the determination of the discursive conditions within which issues are discussed. An important source of tension and concern for the state has been to incorporate the issue of technical efficiency in discussions about the state as noted in the previous chapter. In this sense one must remember the theoretical link between discipline and discourse. The application of discipline is relative to the regime of interpretations in which it is applied. Discipline is about improvement not about repression alone. Thus, defining the terms of what "improvement" means is important for legitimizing the use discipline on certain populations. In this sense, one of the main preoccupations of the state has been to capture and shape narratives of improvement, as seen in the previous chapter. The case of DINEIB and CODENPE are clear manifestations of disciplinary measures being justified according to a specific understanding of improvement and its relationship to a specific state form that I will now call disciplinary modernizing neo-developmentalist - DMN state.

\subsection{Final Reflections: Political Activism and Institutional Autonomy as a Historical Struggle of Indigenous Peoples}

The discursive construct portraying politics as the natural realm of the state has direct relevance for any analysis made about indigenous peoples' organizations. It must be remembered, as many of the indigenous activists, academics, and policy makers I interviewed mentioned, that political participation outside the state apparatus is meaningful given the historical relationship between coloniality and state formation. According to another activist I interviewed (Anonymous Interview, 
Quito, November 19th 2012) policies concerning indigenous peoples must emerge from within indigenous communities themselves and reflect indigenous peoples' diverse cultural realities from an endogenous point of view. Co-optation into the state apparatus can easily lead to the loss of this autonomous capacity to produce what indigenous peoples in Ecuador call pensamiento propio (one's own forms of thinking) as well as to combat and/or dispute unjust and marginalizing practices, ideas and/or institutions (Almeida, 2007; Walsh, 2009).

One of the issues that is worth highlighting from these responses is that the question of politics is essential for indigenous peoples' struggles, particularly in view of the fact that historically, state structures have reflected colonialist institutions, ideas and distribution of material resources (cf. Cox, 1980; Quijano, 2005). While indigenous peoples' struggles have also been about inclusion and fair representation within the state, one cannot ignore the fundamental role that autonomy and the organizational strength of entities like CONAIE have played in the ongoing struggle against various forms of colonialism (from epistemic to cultural) (see Mijeski and Beck, 2011; Becker, 2008; Walsh, 2007). Thus, and notwithstanding some of the policies made by the current state to tackle the issue of discrimination against indigenous peoples (see Chapter Two), the need and importance of understanding participation as a political activity carried out through organized social forces and capable of generating critical discourses about the state, developmental regimes and forms of domination, is fundamental.

It is also worth highlighting the importance of not limiting one's understanding of participation in terms of what could be called ethno-essentialisms: 
including indigenous peoples into the state apparatus because of their "indigenousness." DINEIB, for example, continues to be managed and populated by officials identifying themselves as belonging to indigenous peoples as I witnessed on multiple visits to DINEIB. However, one of the issues that representatives of indigenous peoples, particularly CONAIE, have emphasized is that the meaning of "indigenous" comes from political, cultural and social practices, not from an essentialist understanding of particular individuals being indigenous. In this sense, being indigenous has important links to one's understanding of communities, organizations, institutions other forms of collective forms of expression which continuously redefine what being "indigenous" means. From this standpoint it becomes clear that judging the influence of indigenous organizations in institutions like DINEIB and/or CODENPE cannot be done from the same perspective as one would liberal institutions, for the notion of "equality" and citizenship prevailing in liberal states has not been a benefit indigenous peoples have enjoyed (Guerrero, 2010).

\section{Conclusion}

To conclude I would like to reiterate a central contention of this work, that the exercise of power by the state is defined by the notion of improvement, not state populism, repression or authoritarianism. Improvement entails what could be termed an inclusive regime of exclusion. That is to say, there is no fundamentalist stance adopted by the state against certain populations or individuals. In theory, all Ecuadorians are welcome within the assemblage of improvement, except some 
remain outside of it thereby requiring preparation and/or discipline to eventually join it (cf. Hindess, 2001). Improvement is also a mentality of rule rooted in the exercise of a form of power Foucault called "government" (Foucault, 2000). In this Chapter, however, I have showed that another peculiarity of the Ecuadorian state is the use of discipline as a form of government. I showed that the state's view of discipline is most evident in its relationship with organized indigenous populations (since they are the most vocal critics of the regime of improvement led by the state). I argued that the government of indigenous populations is largely organized/structured by the notion, as Hindess puts it, "that the capacities required for autonomous conduct ... can be developed in a population only through compulsion, through the imposition of more or less extended periods of discipline" (Hindess, 2001: 101). The developmentalist governmentality of the Ecuadorian regime, thus, ought not to be reduced to a caricature of an authoritarian state that indiscriminately targets political opposition. Neither can it be reduced to former exclusionary state types, like the Hacienda or neo-liberal states. Thus, rather than being characterized by an authoritarian ethos, the new state is characterized by a disciplinary one.

I should note, before moving to the next chapter, that the emergence of a disciplinary state form poses a new challenge to indigenous peoples. This new type of struggle may, in some senses, be more difficult. Partly, as Andres Guerrero (2007) notes, the legitimation of indigenous claims, on a larger scale, was the product of indigenous mobilizations and struggles, but also a sense of discontent with the status quo, by larger portions of the population. Now, the thorough political 
domination of Correa and the conception of political legitimacy as strictly electoral make it more difficult for indigenous peoples to attain wider support and to clearly identify who the "enemy" is. Some indigenous organizations have been successfully relegated, once again, to the realm of the backward and uncivilized. Indigenous claims appear abnormal, in a classic Foucauldian sense, in the face of a state that through reverse autoethnography already claims possession over indigenous peoples' symbols and language; a state whose governmentality is fundamentally rooted in limiting the realm of politics to the boundaries of the state itself; and a state whose central government and ruling political "movement" counts with enormous electoral support. Some indigenous populations seem to, once again, lie outside the regime of truth, which is partly but in important ways defined by the state. 


\section{CHAPTER EIGHT CONCLUSION}

This dissertation has argued that the concept of governmental regimes is a useful way of looking into processes of state formation. The state, it has been said, reproduces itself as it comes in contact with society, particularly, as it creates spaces for governmental interventions: fields like "participation," are constituted by government and constitutive of the state. It has also been argued that the state is "composed" of at least three elements: narratives/images, practices and power. In the case of the Ecuadorian state since 2008 narratives about the state have been constructed through the integration of developmental-modernizing images/tropes and Sumak Kawsay/Buen Vivir ones. Its practices are linked both to a technocratic de-politicizing form of government and its exercise of power defined by the coexistence of governmental power and disciplinary power.

This work has problematized the issue of governmental participatory planning by looking at the ways in which planning constitutes a technique of state rule over non-state actors. It was shown how specific strategies, techniques and methods used by SENPLADES operate to construct fields of intervention. Furthermore it has been shown that these practices, including, the knowledgeintensive practices of SENPLADES, constitute a way of bringing the state to regions and places in historically unprecedented ways. As mentioned before, government constitutes a field of intervention through narratives about itself, especially about itself as "the essence of efficacy" and its populations. This process of representation 
is theoretically interesting because it highlights one of Foucault's major contributions to social theory: the union between knowledge and power. When, for instance, some issues are deemed to be technical and therefore outside the realm of politics one observes the conjunction between power and knowledge. Similarly, when a governmental regime represents issues in certain ways and not others, it is exercising power, and, when it deems certain knowledges to be more valid than others, it is exercising power. Similarly, when SENPLADES opens up fields of knowledge about populations and modes of intervention it is making evident that power is also knowledge. In sum, this dissertation contended that certain forms of governmental participatory planning can be regarded as forms of rule because of their capacity to politicize and depoliticize certain issues and not others as well as strategically include and exclude knowledges and their bearers from planning and participatory engagements.

Moreover, it would also be useful to highlight that this dissertation posited that the construction of regimes of government in Ecuador since the election of President Correa unfolded in two distinguishable periods: the pre-Constituent and the post-Constituent periods. The first period was characterized by relatively high levels of civil society participation in highly politicized ways in public affairs. Social forces were actively present in the discussions and debates about the new constitutional content. This dissertation characterized this period as a highly politicized one in part because the different and contending visions of a postneoliberal Ecuador were "allowed" to be fleshed out: there were debates between popular organizations and the state, within the state itself and within organizations 
about issues that were fundamentally political like the type of democracy the state ought to embrace, the type of development paradigm it ought adopt and the type of nation building strategy is should follow (see Acosta, 2009; Ortiz Lemos, 2012). In the end, the Constitution's 444 Articles were in many respects able, as shown in Chapters 3 and 4, to capture this political moment of Ecuador's history.

The second moment has been characterized as a modernizing neodevelopmentalist and disciplinary period. In brief, it is in this period that the Constitution had to be converted into concrete practices and also the moment in which actual state reforms and the constitution of fields of governmental intervention took place. As shown in Chapter Seven in particular, the relationship between indigenous peoples and the state changed in this period. Several conflicts including the 2010 march were met with acts of discipline.

Partly following the research "program" opened by James Ferguson (1994) and continued by Tanya Murray Li (2007a, 2007b), Chapters 5 and 6 focused on the question of a depoliticized form of participation resulting from the intervention of SENPLADES. I contend that de-politicization is not necessarily an intended consequence of government (at least not a consequence intended by government officials) but an unintended effect of governmental power. The research conducted at the PNBV workshops indicates that SENPLADES experts were concerned with enabling participation but I showed, their role as experts often entered into conflict, unintended, with this concern. The PNBV workshops suggested that the depoliticizing effects of government are not necessarily linked to prohibitions, repression, coercion or the calculations of governmental officials. To the contrary, 
coercion and repression may engender even more opposition to the state. This mode of participation is contrary to the participatory movement that characterized the pre-Constituent Assembly days.

It should be said, nonetheless, that my argument as well as the evidence presented in Chapters 5, 6 and 7 do not suggest that de-politicization is an accomplished fact. As mentioned in Chapter Two, de-politicization should be understood as the shifting of politics and political subjectivities from one arena to another. De-politicization is an ongoing process that may or may not succeed in eliminating politics from certain spaces. I do not argue therefore that particular groups or individuals have been de-politicized as such. The argument is that as governmental fields are constructed in such a way that politics is shifted to other arenas. De-politicization is seen as a process that is unstable and susceptible to change but that is incorporated in the very construction of a governmental field of intervention.

Similarly, the dissertation showed that in order to understand the exercise of discipline over indigenous populations it is imperative to provide a historical contextualization of the relationship between the state and indigenous populations. And that was what Chapter Three sought to achieve. More specifically, what Chapter Three from a historical perspective and Chapter Two from a theoretical one argued was that one of the fundamental elements characterizing state-indigenous peoples relations is colonialism. The devaluation of indigenous cosmovisions, the automatic marginalization of their knowledges and the racialization of nationbuilding projects are symptoms of colonial relations. What Chapter Seven showed 
was that colonial discourses continue to be salient in Ecuador. Modes of colonial representation depicting indigenous peoples as backward, ignorant and as being obstacles to development were present in the rhetorical interventions of President Correa during the 2010 march. It was shown that President Correa's words cannot be attributable to his own personal idiosyncrasies but to a larger colonial discourse that permeates Ecuadorian society. This was shown, for instance, by juxtaposing Correa's speeches to those of President Rodrigo Borja who, twenty years earlier, utilized the same expressions to describe indigenous subjectivities.

Hence Chapter Seven argued that the way in which indigenous peoples' participation through mobilizations was met by the government could be characterized as the exercise of disciplinary power rooted in colonial representations of indigenous populations. Chapter Two mentioned that discipline, in a Foucauldian sense, could be conceived as a mechanism to correct and rule populations that are deemed capable of being corrigible. Contrary to the exercise of "pure" forms of authoritarianism it was argued the Correista state did not seek to exclude indigenous populations from its regime of improvement but rather to transform them into adequate subjects capable of being assimilated into what I called modernizing neo-developmentalism. In short, without the colonialist representation of indigenous subjectivities as backward or ignorant, Correa's words could have been interpreted in a different fashion.

\subsection{Theoretical Contributions Revisited}


Perhaps the most important theoretical contributions of this dissertation can be thought of as two sides of the same coin: on the one hand the dissertation shows new ways of looking at processes of state formation through a governmentality lens, and on the other, an expansion of govermentality studies into the study of processes of state formation. This dissertation's theoretical arguments turn the simplicity with which the "the state" is often referenced into a more complex configuration of governmental regimes and power modalities. In synthesis, the state is seen as a series of governmental regimes "composed" of narratives (image component), practices (governmental techniques, knowledges) and forms of power (governmental and disciplinary power). From this perspective the notion of "the state" is questioned: the state is not one, but many - many governmental regimes that may act in harmony, overlap and even contradict one another, as seen in the case of the governmental and disciplinary powers (although these may also be complementary).

The second component of this dissertation's theoretical argument is not entirely novel but its application is. Thomas Lemke (2007) and Bob Jessop (2007, 2008) have argued that governmentality could be a useful lens from which to look at the state. However, very few studies have actually "applied" the governmentality approach to case studies about states and/or processes of state formation. The majority of the governmentality literature focuses on forms of rule beyond the state. An emblematic representation of these works is Nikolas Rose's and Peter Miller's "Political Power beyond the State: Problematics of Government" (1992). As discussed in Chapter Two, Foucault envisioned power in modern society beyond the 
state. The "classic" formulation of governmentality is that government is a form of power that relies on the self-regulation of subjects. Government operated through the desires, wishes and imaginaries of subjects (Dean, 1999; Li, 2007). Consequently students of governmentality have tended to focus on ways in which government can be exercised at a distance through mechanisms like, for example, fashion, dieting, exercising and so on.

This dissertation brings Foucault's preoccupations with power to the realm of the state. If one accepts the premise (derived from genealogy) that fields of government are constructed and not structural features of a state, then it can be argued that it is of fundamental importance to look at how those fields are constructed. This dissertation has argued that fields of government cannot be coercively "forced" or legally obliged to come into existence. The field of participation for instance could not simply be constructed through force (by obliging citizens to participate in governmental planning) or through legal mandates. The government of participation, as shown in Chapter Five, is constructed through knowledge, mentalities and techniques about populations and how to intervene is society developed by the state and through the populations' wilful engagement in the governmental schemes.

It is important also, from a historical point of view, to understand that laws, regulations, and formal institutions are not as effective as predictors or mechanism to interpret state actions in countries like Ecuador where there is a clear history of weak institutionalization. Traditionally forms of rule in Ecuador as mentioned in Chapter Three have been rooted in, for example, clientelism, discipline, 
authoritarianism, charismatic leadership as well as legal/rational authority. Laws and formal institutions are, no doubt, important for understanding the state and state power but a complete analysis of the state, particularly in Ecuador, must go beyond an analysis of formal institutions, laws, regulations and so on. Governmentality can be interpreted precisely as an analysis of government/rule beyond juridical forms, beyond the form of the law and, this dissertation has argued, this form of analysis is highly relevant for places where the formal institutions are weak.

Finally, the theoretical as well as empirical implications of this dissertation's arguments are that in the case of Ecuador, the cohesiveness and strength of the state cannot be reduced to the charismatic figure of President Correa. The dissertation sought to illustrate this contention by emphasizing the multifarious elements that characterize the Ecuadorian state: its neodevelopmentalist, modernizing and disciplinary dimensions. These aspects of the state are much more complex than the charismatic-leader thesis would admit. For example, Chapter Five showed how the use of reverse-auto-ethnography has been instrumental in the development of the state as image. Reverse auto-ethnography reveals a technique of government that strips Sumak Kawsay/Buen Vivir narratives of their radical content. The presence of reverse auto-ethnography as a governmental technique alone reveals that the strength of the state cannot be reduced as some authors do (see De la Torre, 2009) to the charismatic authority of a leader.

\subsection{Opportunities for Future Research}


The arguments presented in this work have opened a number of potential avenues for research about the state, particularly through the idea of regimes of government. There are, I would argue, a number of new opportunities for future research from the local to the regional level. The first is to extend the scope and coverage of primary research to participatory workshops beyond the PNBV. One of SENPLADES's important claims about its work is that it is highly participatory (see SENPLADES, PNBV, 2013-2017, 2014: 35-38). However, if the arguments presented in this thesis are plausible the expansion of participation may entail the further and further shifting of politics and this could eventually create conflict of another kind (i.e. violent conflict). Thus, an important avenue for future research is to evaluate on a wider scale the participatory processes that SENPLADES caries out outside of the PNBV.

The second possible avenue opened by the arguments developed here would be to study, employing the theoretical tools developed here, the issue of participatory democracy in a regional, comparative context. Hailed as a better alternative to representative liberal democracy (see Ellner, 2012), research about participatory or radical democracy at the regional level is rather scarce. Particularly, it would be interesting to compare the experiences of Bolivia and Ecuador and their respective processes of state formation. Both countries have had Constituent Assemblies and both have undertaken developmentalist state reforms (Ellner, 2012; Escobar, 2010). The process of change in both countries has also been influenced by Sumak Kawsay/Buen Vivir (Suma Qamaña in Bolivia) type narratives and concrete experiences of indigenous peoples. Thus it would be interesting to ask 
whether or not their strategies of state formation have followed similar paths. Can one observe in the Bolivian case a governmentalization of spaces of participation? How does the Bolivian state react, relate to challenges from popular organizations in the area of participatory planning? Is there a de-politicizing dispositif in the Bolivian state? How does it operate? It was argued, following the conceptual framework of regimes of government that the Ecuadorian state could be characterized as a modernizing-neodevelopmental state. How could its Bolivian counterpart be characterized?

Third, this dissertation evoking the "spirit" of James C. Scott's "seeing like a State" (1998) has looked at the issue of de-politicization from the vantage point of the state. This leaves out the other central component in the formation of states: civil (political) society, particularly indigenous peoples' organizations. Even though this work does analyze aspects of state-society relations, it would be interesting to conduct an in-depth, comparative study, from the perspective of non-state actors, of what participatory processes have entailed and whether these are worth reproducing, modifying or eliminating. An interesting aspect of this dissertation research is that it reveals that the governmentalized from of participation that characterizes it, is generally conducted in relatively small spaces, at least the experience of the PNBV shows that. What are the implications of this from the perspective of non-state actors?

Moreover, while my work focused on the depoliticizing "nature" of governmental techniques, expert knowledge, and workshop methodologies, it would be important to know what other dynamics of rule exist in small-scale participatory 
processes. Specifically, I am thinking about gender forms of domination. In an interesting study of participatory processes in the Intag region of Ecuador researcher Karen Hildahl (2011 - unpublished; used by permission of the author) found that there are many governmentality-type ${ }^{37}$ forms of rule that are genderbiased. For example, she found that time commitments for community participation were different for men and women. Women worked longer hours than men and had therefore less time to participate. Similarly, the relatively (to men) low rate of longterm participation of women in public meetings means that speaking-time during workshops and community meetings is mostly used by men. The result of these factors combined is that women's voices are not heard as much and thus cultural systems like machismo are reproduced.

Finally, an ambitious avenue for future research that can be derived from this work is to establish from a wider and comparative empirical perspective what characterizes the relationship between the state as a historical formation and popular participation, particularly from indigenous peoples. Catherine Walsh (2010) has suggested in the case of Ecuador that the state and "traditional" forms of development (the human development paradigm specifically) are one and the same. She notes:

[A] question and concern has to do with the meaning and orientation of development. In both the previous Plan [PNBV] and this most recent one [2010-2013], development is conceived in the context of the state; that is to say, development is the strategy by which state reform will occur,

\footnotetext{
${ }^{37}$ Hildahl does not employ the concept of governmentality.
} 
permitting the state to recuperate its capacities of management, planning, regulation, and redistribution (SENPLADES, 2009). In this sense buen vivir as development is the state. And it is the state that signifies in technocratic, economistic, and humanistic terms what is development and buen vivir (Walsh, 2010: 20; emphasis in original).

In this context, it would be worth asking whether a politicized sense of participation that challenges the entanglement between development and state (this relationship has in fact been challenged by indigenous peoples through the notion of the 'plurinational' state) is compatible, if at all, with modern forms of rule and, more generally, with the state as a historical formation.

This question poses an interesting dilemma because a politicized form of participation, free of the limitations of technocratic entanglements (cf. Kothari and Cooke, 2001), must remain rooted in a strong organizational base from within civil society that is capable of challenging the state in a constructive way and on a constant basis. Being organized is fundamental to participation. As Mark Turner notes, when citizenship rights are extended from above, it is often the case that citizens become mere subjects instead of active "bearers of claims against society via the state" (Turner, 1990: 200; emphasis added). Similarly, as Conway (2004: 374) puts it, the development of a truly inclusive citizenship "...is secured from below through the active struggle of people claiming political subjectivity." In other words, the ideal of citizenship in participatory democracy requires an active participation of groups of citizens capable of challenging the state by exercising their capacities of reasoning, discussion, socializing and mobilization. Participation 
implies a degree of autonomous deliberation, and political expression which could be understood, I would argue, as "a set of cultural, symbolic and political practices through which individuals and groups claim new rights or struggle over existing rights (Ku, as cited in Preibisch, 2007: 99). 


\section{Bibliography}

Acosta, A. (2008). "El sentido de la refundación constitucional en tiempos de crisis." Tendencia: Revista de análisis político, 7: 13-17.

Acosta, A. (2010). "Maldiciones que amenazan la democracia". Revista Nueva Sociedad, 229: 42-61.

Acosta. A, (2011). "EI Buen Vivir en el camino del post-desarrollo. Algunas reflexiones al andar." In G. Weber, Debates sobre cooperación y modelos de desarrollo. Perspectivas desde la sociedad civil en el Ecuador. Quito: Centro de Investigaciones CIUDAD Observatorio de la Cooperaci6n al Desarrollo en Ecuador.

Adoum, J. E. (1998). Ecuador: señas particulares. Quito: Eskeletra.

Agrawal, A. (1996). "Poststructuralist Approaches to Development: Some Critical Reflections." Peace \& Change, 21(4): 464-477.

Aguirre, M (Ed.), (2000). Ecuador hoy: cien miradas, Quito: Flacso sede Ecuador and El Comercio-Ediecuatorial.

Alcoff, L. M. (1999). "Philosophy and racial identity." In Ethnic and Racial studies today, M. Bulmer \& J. Solomos (Eds.): 29-45. New York: Routledge.

Alianza PAIS (2006) Plan de Gobierno del Movimiento PAIS, 2007 - 2011.

Retreieved from: http://www.scribd.com/doc/31619413/Plan-de-GobiernoAlianza-PAIS

Almeida, P. (2007). "Defensive mobilization: popular movements against economic adjustment policies in Latin America." Latin American Perspectives, 34 (3): 123-139.

Alvarez, F. (2011). “La etica del buen vivir, ética del morir bien.” In G. Weber, Debates sobre cooperación y modelos de desarrollo. Perspectivas desde la sociedad civil en el Ecuador. Quito: Centro de Investigaciones CIUDAD Observatorio de la Cooperaci6n al Desarrollo en Ecuador.

Anderson, B. (1991). Imagined Communities. London: Verso.

Andolina, R. (2003). "The Sovereign and its Shadow: Constituent Assembly and Indigenous Movement in Ecuador." Journal of Latin American Studies, 35(4), 721-750.

Andolina, R., N. Laurie, and S. A. Radcliffe (2009). Indigenous Development in the Andes.Culture, Power, and Transnationalism. Durham: Duke University Press. 
Andrade, P. (2009). Democracia y cambio político en el Ecuador: Liberalismo, política de la cultura y reforma institucional, Quito: Universidad Andina Simón Bolívar and Corporación Editora Nacional.

Andrade, P. (2012) "Los intelectuales en su laberinto (la ilusión de los político)." Ecuador Debate, 85: 35-48.

Argones, N. (1985). El juego del poder. Quito: Corporación Editora Nacional.

Arias, J. and E. Restrepo (2010). "Historizando raza: propuestas conceptuales y metodológicas." Crítica y Emancipación, 2(3): 45-64.

Arnold, D. Y. (Ed.) (2009). ¿Indígenas u obreros? La construcción política de identidades en el Altiplano boliviano. La Paz: Fundación UNIR Bolivia.

Ayala Mora, E. (1991). "Ecuador Since 1930," in Leslie Bethel (Ed.), The Cambridge History of Latin America: 1930 to the Present Vol.VIII. Cambridge: Cambridge University Press.

Ayala Mora, E. (2002). Historia de la revolucion liberal ecuatoriana. Quito: Corporación Editora Nacional. Taller de Estudios Historicos.

Ayala Mora, E. (2008). Resumen de Historia del Ecuador, Quito: Corporación Editora Nacional.

Ayala Mora, E. (2011). “Del Neoliberalismo al Socialismo del Siglo XXI.” In J.C. Proaño, and N.C. Ruíz (Eds.) Observatorio Latinoamericano, 7, Dossier Ecuador. Buenos Aires, Instituto de Estudios de América Latína y el Caribe, Facultad de Ciencias Sociales, Universidad de Buenos Aires.

Bastian, S. and R. Luckham (Eds.) (2003). Can Democracy Be Designed? The Politics of Institutional Choice in Conflict-Torn Societies. London: Zed Books.

Bebbington, A and D. Humphreys (2011). "An Andean Avatar: Post-Neoliberal and Neoliberal Strategies for Securing the Unobtainable." New Political Economy, 16 (1): 131-145

Beck, S. and K. Mijeski (2000). "Indigena Self-Identity in Ecuador and the Rejection of Mestizaje." Latin American Research Review, 35(1).

Becker, M. (2008). Indians and Leftists in the Making of Ecuador's Modern Indigenous Movements. Durham: Duke University Press.

Becker, M. (2011). iPachakutik! Indigenous Movements and Electoral Politics in Ecuador. Plymouth: Rowman \& Littlefield Publishers, Inc. 
Bastian, S. and N. Bastian, (Eds) (1996) Assessing Participation: a Debatefrom South Asia. Delhi: Konark Publishers.

Becker, M., (2011) Correa, Indigenous Movements, and the Writing of a New Constitution in Ecuador. Latin American Perspectives, 38 (1): 47-62.

Biggs, S \& Neame, A. (1995) Negotiating Room for Maneuver: Reflections Concerning NGO autonomy \& Accountability Within the New Policy Agenda, in Edwards, M \& Hulme, D (Eds) NGOs-Performance \& Accountability: Beyond the Magic Bullet, London: Earthscan Publications.

Bhabha, H. (1998). Nation and Narration. London: Routledge.

Blackledge, A. (2008). “Critical Discourse Analysis.” In The Blackwell Guide to Research Methods in Bilingualism and Multilingualism, W. Li \& M. Moyer (Eds.). Oxford: Blackwell.

Boaventura de Sousa Santos. (2006). "The World Social Forum as epistemology of the South." In The Rise of the Global Left: The World Social Forum and Beyond: 13-35. London: Zed Books.

Burbano de Lara, F. (Comp.). (2003). Democracia, cultura política y gobernabilidad los estudios políticos en los años noventa. Quito: FLACSO - Sede Ecuador.

Burchell, G. (1991). "Peculiar interests: Civil society and governing the system of natural liberty." In The Foucault Effect. Studies on Governmentality, G. Burchell , C. Gordon \& P. Miller (Eds.). London: Harvester.

Burchell, G., C. Gordon and P. Miller (Eds.) (1991). The Foucault Effect. Studies on Governmentality. Chicago: University of Chicago Press.

Burbano de Lara, F. (1998). "A modo de introducción: el impertinente populismo" en F. Burnano de Lara (Ed.), El fantasma del populismo. Aproximación a un tema [siempre] actual. Caracas: ILDIS-FLACSO-Nueva Sociedad, 9-24.

Campbell, D. (1990). "Global Inscription: How Foreign Policy Constitutes the United States," Alternatives 15(3): 263-286.

Cardoso E. and E. Faletto (1971). Dependency and Development in Latin America. Translated by Marjory Mattingly Urquidi. Berkely: University of California Press

Carrion, Benjamin (1984) Garcia Moreno: el santo del patibulo. Quito Editorial Conjeo 
Carter Center (2008). Report on the National Constituent Assembly of the Republic of Ecuador. No. 1, Quito, Ecuador. Retrieved from:

http://www.cartercenter.org/resources/pdfs/news/peace_publications/am ericas/english_The_Carter_\%20Center_Report1_Ecuador_Constituent_Assem bly_January08.pdf.

Castro-Gómez, S. (2002). “The Social Sciences, Epistemic Violence, and the Problem of Invention of the Other." Nepantla, 3(2): 269-285.

CEEAASES (2013). “Categorización de Universidades.” Retrieved from: http://www.ceaaces.gob.ec/images/stories/categorizacion/categorizacin.p df, visited on November 23.

Cervone, E. (2009). “Los Desafíos del Multiculturalismo." In Repensando los Movimientos Indígenas, C. Martínez (Ed.): Repensando Los Movimientos Indígenas, Quito: FLACSO, 199-215

Cervone, E. (2010) "Celebrating the Chagras: Mestizaje, Multiculturalism, and the Ecuadorian Nation," The Global South, 4(1).

Chakrabarty, D. (2000). Provincializing Europe. Postcolonial Thought and Historical Difference. Princeton: Princeton University Press.

Chambers, R. (2007). "From PRA to PLA and Pluralism: Practice and Theory." IDS Working Paper 286, Institute of Development Studies, Brighton.

Chandler, D. (2010). International Statebuilding: The Rise of Post-Liberal Governance. London: Routledge.

Chiriboga, M. (2011). "¿Acceso limitado o sociedad abierta?. El Universo, Ecuador, March 13. Retrieved from: http://www.eluniverso.com/2011/03/13/1/1363/acceso-limitadosociedad-abierta.html

Clark, K. A. (1998). “Race, 'Culture,' and Mestizaje: The Statistical Construction of the Ecuadorian Nation, 1930-1950.” Journal of Historical Sociology, 11(2): 185211

Clark, K. and M. Becker (Eds.) (2007). Indigenous peoples and state formation in Modern Ecuador, Pittsburgh: Pittsburgh University Press.

Cleaver, F. (2001). "Institutions, Agency and the Limitations of Participatory Approaches to Development." In Cooke, B. and U. Kothari (Eds.), Participation: The new Tyranny? London: Zed Books, 36-56.

Cleaver, F. (2003). "The inequality of social capital: agency, association, and the 
reproduction of chronic poverty." Paper presented at Staying Poor: Chronic Poverty and Development Policy Conference, University of Manchester April 7-9, Manchester, UK.

CODENPE (2014). “Mapa del Territorio de Nacionalidades y Pueblos del Ecuador.” Retrieved from http://www.codenpe.gob.ec/index.php?option=com_content\&view=article\&i $\mathrm{d}=125 \&$ catid $=96$

Cohen, J. and Arato, A. (1994). Civil Society and Political Theory. Cambridge: MIT Press.

Colloredo-Mansfeld , R. (1998). “'Dirty Indians', Radical Indígenas, and the Political Economy of Social Difference in Modern Ecuador," Bulletin of Latin American Research, 17(2).

Conaghan, C. (1985). “Democracy by Attrition: Parties, Civil Society, and Political Order in Ecuador." Paper for the Conference on Redemocratization in Latin America, March 28-30, University of Pittsburgh.

Conaghan, C. (1987). "Party Politics and Democratization in Ecuador.” In J. Malloy \& Seligson, M.A (Eds.), Authoritarians and Democrats. Pittsburgh: University of Pittsburgh Press.

Conaghan, C. (1988). "Capitalists, Technocrats, and Politicians: Economic PolicyMaking and Democracy in the Central Andes." Working Paper 109, Kellogg Institute for International Studies.

Conaghan, C. and J. M. Malloy. (1994). Unsettling Statecraft : Democracy and neoliberalism in the central Andes, Pittsburgh : University of Pittsburgh Press.

Conaghan C.M. and C. de la Torre. (2008). “Correa's Plebiscitary Presidency.” Journal of Democracy, 19(2): 46-60.

CONAIE (2013). Sobre Nosotros. Retrieved from: http://www.CONAIE.org/sobrenosotros/que-es-la-CONAIE

Constitución de la República del Ecuador. (2008a). Article 1. Retrieved from: http://www.asambleanacional.gob.ec/documentos/constitucion_de_bolsillo. pdf.

Constitución de la República del Ecuador. (2008b). Article 2. Retrieved from: http://www.asambleanacional.gob.ec/documentos/constitucion_de_bolsillo. pdf. 
Constitución de la República del Ecuador. (2008c). Articles 35-55. Retrieved from: http://www.asambleanacional.gob.ec/documentos/constitucion_de_bolsillo. pdf.

Constitución de la República del Ecuador. (2008d). Article 280. Retrieved from: http://www.asambleanacional.gob.ec/documentos/constitucion_de_bolsillo.pdf.

Cooke, B. (2003). "A New Continuity with Colonial Administration: Participation in Development Management.” Third World Quarterly, 24(1): 47-61.

Cooke, B. and U. Kothari (Eds.). (2001). Participation: The new tyranny? London: Zed Books.

Correa, R. (2010). Ecuador: de Banana Republic a la No República. Bogotá: Random House Mondadori.

Cox, R.W. (1981). "Social Forces, States and World Orders: Beyond International Relations Theory." Millennium: Journal of International Studies, 10(2): 126155.

Cox, R.W. (1983). "Gramsci, Hegemony and International Relations: An Essay in Method." Millennium: Journal of International Studies, 12(2): 162-175.

Crain, M. (1990). The Social Construction of National Identity I Highland Ecuador. Anthropological Quarterly, 63(1), 43-59.

Crain, M. (1996) The Political Tensions of Representations and Misrepresentations: Intellectuals and Mestizas in Cuzco (1919-1990), Journal of Latin American Anthropology 2(1).

Cronin, C. (1996). "Bourdieu and Foucault on Power and Modernity." Philosophy and Social Criticism, 22(6): 55-85.

Cuvi, J., D. Machado, A. Oviedo and N. Sierra (Eds). (2013). El correísmo al desnudo. Quito: Montecristi Vive.

Dargatz, A and M. Zuazo. (2012). Democracias en Transformación: ¿Qué hay de nuevo en los nuevos Estados andinos? La Paz: Impreso en Creativa.

Dean, M. (1999). Governmentality: Power and Rule in Modern Society. London: Sage.

Dean, M (2002). "Liberal government and authoritarianism." Economy and Society." 31(1), 37-61.

Deans, Malcom (2002), Ecuador and Venezuela, c, 1880-1930. In L. Bethell (Ed.), The Cambridge history of Latin America. Vol. V c. 1870 to 1930. 
De la Cadena, M. (Ed.) (1999). Formaciones de indianidad. Articulaciones raciales, mestizaje y nación en América Latina, Popayán: Envión.

De la Cadena, M. (2005). "Are mestizos hybrids? The conceptual politics of Andean Identities," Journal of Latin American Studies, 37(2): 259-284.

De la Cadena, M. (2010). "Indigenous Cosmopolitics in the Andes: Conceptual Reflections beyond 'Politics'”. Cultural Anthropology, 25(2): 334-370.

De la Torre, P. (1989). Patrones y conciertos: Una hacienda serrana. Quito: Corporación Editora Nacional.

De la Torre, C. (1997). "Populism and Democracy: Political Discourses and Cultures in Contemporary Ecuador." Latin American Perspectives , 24(3): 12-24.

De la Torre, C. (2013). “El tecnopopulismo de Rafael Correo ¿Es compatible el carisma con la tecnocracia?" In Cuvi, J., D. Machado, A. Oviedo and N. Sierra (Eds), El correísmo al desnudo. Quito: Montecristi Vive, 39-52.

Diario Hoy (2010). “A 60 Años del Primer Censo." November 28 $8^{\text {th }}$. Retrieved from: http://www.hoy.com.ec/noticias-ecuador/a-60-anos-del-primer-censo444303.html).

Diario Hoy (2013). "Carlos Perez Guartambuel es llevado a la carcel para cumplir su sentencia." March 21st, Retrieved from: http://www.hoy.com.ec/noticiasecuador/carlos-perez-guartambel-es-llevado-a-la-carcel-para-cumplir-susentencia-576903.html

Diario Hoy (2013). “Correa, el suizo." April 9th. Retrieved from: http://www.hoy.com.ec/noticias-ecuador/correa-el-suizo-578257.html

Dosh, P. \& N. Kligerman. (2009). "Correa vs. Social Movements: Showdown in Ecuador." NACLA Report on the Americas, 42(5): 21-24.

Drinot, P. (2011). "The Meanining of Alan Garcia: Sovereignty and Governmentality in Neoliberal Peru." Journal of Latin American Cultural Studies, 20(2): 179195.

Echeverría, B. (2011). Modernidad y blanquitud. Mexico: Ediciones Era.

ECLAC [CEPAL], (2012) "Panorama Social de America Latina y el Caribe, 2012". United Nations and ECLAC. Retrieved from: http://www.eclac.org/publicaciones/xml/5/48455/PanoramaSocial2012Do cI-Rev.pdf 
Ecuarunari (2008). "Resoluciones de la Asamblea Nacional." Retrieved from: http://www.ecuarunari.org/es/nosotros/no_20080730

El Ciudadano. (2009). "Gobierno pide auditoría para el Codenpe." January 24, retrieved

at"http://presidencia.informatica.gob.ec/index.php?option=com_content\&vi ew $=$ article\&id=103:gobierno-pide-auditoria-para-elcodenpe $\&$ catid=2: politica $\&$ Itemid $=43$.

El Comercio (2008a). "La Conaie anticipa una postura crítica." January 14, retrieved from: http://www.elcomercio.com/noticias/Conaie-anticipa-posturacritica_0_163185787.html

El Comercio (2008b)."La Conaie, resentida por declaraciones de Correa." May 19, retrieved from: http://www.elcomercio.com/noticias/Conaie-resentidadeclaraciones-Correa_0_165587263.html

El Comercio (2009a). "Remezón en la escuela Bilingüe". March 03, retrieved from :http://www.elcomercio.com/noticias/Remezon-escuelabilingue_0_7799565.html

El Comercio (2009b). “La Dineib sacudida por el decreto 1585.” February 02, retrieved from: http://www.elcomercio.com/noticias/Dineib-sacudidaDecreto_0_7199814.html

El Comercio (2009c)."El Codenpe se queda sin presupuesto". January 26, retrieved from:http://elcomercio.com/noticias/Codenpe-quedapresupuesto_0_6600494.html

El Comercio, (2013b). "El fraude de Pegaso y su gran éxito mediático.” April 29, retrieved from: http://www.elcomercio.com/blogs/desde_la_tranquera/Pegaso-sateliteEcuador_7_910178976.html

Elden, S. (2007). “Rethinking Governmentality.” Political Geography, 26, 29-33.

Ellner, S. (2012). “The Distinguishing Features of Latin America's New Left in Power: The Chávez, Morales, and Correa Governments." Latin American Perspectives, 182(39)(1): 96-114.

El Telégrafo (2012). "La inversión pública lidera en la región." July 19, retrieved from: http://www.telegrafo.com.ec/economia/item/la-inversion-publicadel-ecuador-lidera-en-la-region.html). 
El Universo (2011a). "El 2010 fueron más de cien los criticados en los enlaces." January 1st. Retrieved from:

http://www.eluniverso.com/2011/01/01/1/1355/2010-fueron-mas-ciencriticados-enlaces.html

El Universo, (2011b), "Asambleísta César Montúfar recibió un golpe en su ojo por militante de Alianza PAIS." April, $30^{\text {th }}$. Retrieved from: http://www.eluniverso.com/2011/04/30/1/1355/asambleista-cesarmontufar-recibio-un-golpe-ojo-militante-alianza-pais.html

Escobar, A. (1995). Encountering Development. The Making and Unmaking of the Third World. Princeton: Princeton University Press.

Escobar, A. (2001). "Culture sits in places: reflections on globalism and subaltern strategies of localization." Political Geography 20, no. 2:139-174.

Escobar, A. (2008). Territories of Difference. Place, Movements, Life, Redes. Durham: Duke University Press.

Escobar, A. (2010)."Latin America at the Crossroads: Alternative Modernizations, Postliberalism, or Postdevelopment?" Cultural Studies, 24(1): 1-65.

Espinosa Apolo, M. (1999). Los mestizos ecuatorianos y las señas de identidad cultural. Quito: Tramasocial.

Espinoza, A. (2011). “Escuela Politécnica Nacional: historia, régimen académico y perspectivas." In L. Pacheco (Ed.), Historia de la Universidad del Ecuador. Quito: Simposio Permanente sobre laUniversidad, PUCE.

Evans, P. (1995). Embedded Autonomy: States and Industrial Transformation. Princeton: Princeton University Press.

Evans, P. (1999). "Transnational Linkages and the Economic Role of the State: An Analysis of Developing and Industrialized Nations in the Post-World War II Period" In Evans, P.E, D. Rueschemeyer and T. Skocpol (Eds), Bringing the State Back In. (1999).Cambridge: Cambridge University Press, 192-226.

Evans, P., D. Rueschemeyer and T. Skocpol (Eds.). (1999). Bringing the State Back In. (1999). Cambridge: Cambridge University Press.

Ferguson, J. (1994). The Anti-Politics Machine: Development, Depoliticization, and Bureaucratic Power in Lesotho. Minneapolis: University of Minnesota Press.

Foote, N. (2006). "Race, State and Nation in Early twentieth Century Ecuador." Nations and Nationalism, 12(2). 
Foucault, M. (1972). The Archeology of Knowledge and the Discourse on Language. New York: Pantheon Books.

Foucault M. (1997). Ethics: Subjectivity and Truth. Essential Works of Michel Foucault, 1954-1984. Vol. 1. New York: New Press.

Foucault, M. (1980). Power/Knowledge: Selected Interviews \& Other Writings 19721977. New York: The Harvester Press.

Foucault, M. (1983). “Afterward.” In Michel Foucault: Beyond Structuralism and Hermeneutics, H. Dreyfus \& P. Rabinow (Eds.): 208-226. Chicago: University of Chicago Press.

Foucault, M. (1988). Madness and Civilization: A History of Insanity in the Age of Reason. New York: Vintage Books.

Foucault, M. (1991). “Governmentality.” In The Foucault Effect: Studies in Governmentality, G. Burchell, C. Gordon, \& P. Miller (Eds.), Chicago: The University of Chicago Press. 87-104.

Foucault, M. (1994a). Power: The Essential Works of Foucault 1954 - 1984. Vol 3, J.D. Faubion (Ed.), Rabinow, P. (series ed). New York: The New Press.

Foucault, M. (1994b). "Useless to Revolt?.” In Power: The Essential Works of Foucault, 1954-1984, Vol. 3, J. Faubion (Ed.): 449-453. New York: New Press.

Foucault, M. (1995). Discipline and Punish: The Birth of the Prison. New York: Pantheon Books.

Foucault, M. (1997). Ethics: Subjectivity and Truth. Essential Works of Michel Foucault, 1954-1984. Vol. 1, Rabonow, P. (Ed.). New York: New Press.

Foucault, M. (2000a). Defender la sociedad: Curso en el Collège de France (19751976). Buenos Aires: Fondo de Cultura Económica de Argentina S.A.

Foucault, M. (2000b). "'Omnes et singulatim': Toward a critique of political reason." In Power: Essential Works of Foucault 1954-1984, J. Faubion (Ed.): 298-325. New York: New Press.

Foucault, M. (2000c). "Space, knowledge, and power." In Power: Essential Works of Foucault 1954-1984, J. Faubion (Ed). New York: New Press.

Foucault, M. (2000d). "The subject and power." In In Power: Essential Works of Foucault 1954-1984, J. Faubion (Ed). New York: New Press. 
Foucault, M. (2003). Society must be Defended: Lectures at the Collège de France, 1975-76, New York: Picador

Foucault, M. (2007). Security, Territory, Population: Lectures at the College de France, 1977-78, G. Burchell (Trans.). New York: Palgrave Macmillan.

Foucault, M. (2008). The Birth of Biopolitics: Lectures at the Collège de France 197879. New York: Palgrave Macmillan.

Foucault, M. (2009). La hermenéutica del sujeto. Buenos Aires: Fondo de Cultura Económica.

Foucault, M. (2010). The Government of Self and Others: Lectures at the College de France 1982-1983. Edited by F. Gros. London: Palgrave Macmillan.

Geertz, C. (1973). The Interpretation of Cultures: Selected Essays. New York: Basic Books.

Geertz, C. (1980). Negara: The Theatre State in Nineteenth-Century Bali. Princeton: Princeton University Press.

Geertz, C. (1983). Local Knowledge: Further Essays in Interpretative Anthropology. New York: Basic Books.

Graham, A. (1971). Essence of Decision: Explaining the Cuban Missile Crisis. Boston: Little Brown.

Gramsci, A. (1985). Selections from cultural writings / Antonio Gramsci; David Forgacs and Geoffrey Nowell-Smith (Eds.), London: Lawrence and Wishart.

Guerrero, A. (1997). "Poblaciones indígenas, ciudadanía y representación." Nueva Sociedad, 150: 98-105.

Guerrero, A. (2010). Sociedad Ventrílocua. Quito: Flacso, sede Ecuador.

Guerrero, A. and T. Platt (2000). "Proyecto antiguo, nuevas preguntas: la antropología histórica de las comunidades andinas cara al nuevo siglo". In Hans Joachim König, Tristan Platt y Colin Lewis (Eds.), Estado-nación, comunidad indígena, industria. Tres debates al final del Milenio. Ridderkerk, Países Bajos: Ridderprint. Cuadernos de Historia Latinoamericana № 8: 95113.

Habermas, J. (1984) Theory of Communicative Action: Reason and the rationalization of Society, Volume 1. Boston: Beacon Press.

Hale, C. R. (1997). “Cultural Politics of Identity in Latin America." Annual Review of 
Anthropology, 26, 567-590.

Harnecker, M. (2010). "Los gabinetes itinerantes en Ecuador: Una forma de acercar el gobierno al pueblo." Rebelión, online issue. Retrieved from: http://www.rebelion.org/docs/117764.pdf

Haugaard, M. (2012) Rethinking the Four Dimensions of Power: Domination and Empowerment." Journal of Political Power, 5(1): 33-54.

Heckman, S. (1997). "Truth and Method: Feminist Standpoint Theory Revisited." Signs, 22(2): 341-365.

Heller, M. (2008). “Doing Ethnography.” In The Blackwell Guide to Research Methods in Bilingualism and Multilingualism. W. Li \& M. Moyer (Eds.). Oxford: Blackwell, 249-262.

Hildahl, K. (2010). Linking Gender and Climate Change Mitigation: A Case Study of a Global Environment Facility Small Grants Programme Project in Ecuador". Masters Thesis, Carleton University, Unpublished.

Hindess, B. (1996). Discourses of Power: From Hobbes to Foucault. Oxford: Blackwell Publishing.

Hindess, B. (1997). "Politics and Governmentality." Economy and Society, 26(2): 257272.

Hindess, B. (2001). "The Liberal Government of Unfreedom." Alternatives, 26: 93111.

Hindess, B. (2002). “Neo-liberal Citizenship. Citizenship Studies.” 6(2), 127-143.

Hindess, B. (2004a). Liberalism-What's in a Name? In W. Larner \& W. Walters (Eds.), Global Governmentality: Governing International Spaces. London: Routledge, 23-29.

Hindess, B. (2004c). Power, Government, Politics. In K. Nash and A. Scott (Eds.), The Blackwell Companion to Political Sociology. Oxford: Blackwell Publishing, 40-48.

Hindess, B. (2005a). Politics as Government: Michel Foucault's Analysis of Political Reason. Alternatives, 30, 388-413.

Hindess, B. (2005b). Investigating International Anti-Corruption. Third World Quarterly, 26(8), 1389-1398. 
Hurtado, O. (1995). Los Costos del Populismo. Quito: CORDES

INEC -Instituto Ecuatoriano de Estadísticas y Censos (2011). VI Censo de población y vivienda - 2001, Retrieved from: http://www.inec.gob.ec/web/guest/ecu_est/est_soc/cen_pob_viv. Last accessed March 17th, 2011.

Jackson, P.T. (2008). "Foregrounding Ontology: dualism, monism and IR theory." Review of International Studies, 34: 129-153.

Jackson, R. H. (2007). "Race and the Definition of 'Indian': Identity on the Fringes of Colonial Spanish America." Revista de Estudios Sociales, 26(11).

Jaeger, H-M. (2007). "'Global Civil Society"' and the Political Depoliticization of Global Governance." International Political Sociology, 1(3), 257-277.

Jaeger, H-M. (2010). "UN Reform, Biopolitics and Global Governmentality.” International Theory, 2(1): 50-86.

Jameson, K. (2011). "The Indigenous Movements in Ecuador: The Struggle for a Plurinational State." Latin American Perspectives, 176(38).

Jessop, B. (1990). State Theory: Putting Capitalist Economies in their Place. Cambridge: Polity.

Jessop, B. (2007). "From Micro-Powers to Governmentality: Foucault's Work on Statehood, State Formation, Statecraft and State Power." Political Geography, 26: $34-40$.

Jessop, B. (2008). State Power. Cambridge: Polity Press

Johnson, C. (1992). Miti and the Japanese Miracle: The Growth of Industrial Policy, 1925-1975. Stanford: Stanford University Press.

Joseph, J. (2007). "Philosophy in International Relations: A Scientific Realist Approach," Millennium 35(2): 345-359.

Kelly, N. (2003). Más allá del cholo: Evidencia lingüística del racismo poscolonial en el Ecuador. Universidad de Guadalajara: Departamento de Letras.

Kingman, E. (2009). "Cultura popular, vida cotidiana y modernidad periférica." Quaderns, 25: 47-69

Kingman, E. (2002). "Identidad, mestizaje, hibridación: sus usos ambigüos,” Proposiciones, 34. 
Kothari, U. (2001). "Power, Knowledge and Social Control in Participatory Development”. In Cooke, B. and U. Kothari (Eds.) (2001). Participation: The new tyranny? London: Zed Books, 139-153.

Kolodny, N. (1996). " The Ethics of Cryptonormativism: A Defense of Foucault's Evasions". Philosophy and Social Criticism, 22(5): 63-84.

Korovkin, T. (1997). "Indigenous Peasant Struggles and the Capitalist Modernization of Agriculture: Chimborazo, 1964-1991." Latin American Perspectives, (24)3: 25-49.

Korovkin, T. (2002). "In search of dialogue? oil companies and indigenous peoples of the Ecuadorian Amazon," Canadian Journal of Development Studies, 23 (4).

Korovkin, T. (2002). "In search of dialogue? oil companies and indigenous peoples

Laclau, E. (1995). La Razón Populista. Buenos Aires: Fondo de Cultura Económica Argentina.

Laclau, E. \& C. Mouffe (1985). Hegemony and Socialist Strategy: Towards a Radical Democratic Politics. London: Verso.

Lalander, P. And P. Ospina (2012) "Movimiento indígena y revolución ciudadana en Ecuador," Cuestiones Políticas, 28(48): 13-50.

Larrea, A.M. (2008). "La plurinacionalidad: Iguales y diversos en busca del sumak kawsay." In: Acosta, A., Moreano, M. (Eds.), Entre el quiebre y la realidad: Constitución 2008. Abya-Yala, Quito, pp. 77-85.

Larrea, A.M. (2010). "La disputa de sentidos por el buen vivir como proceso contra hegemónico." In Los nuevos retos de América Latina. Socialismo y Sumak Kawsay, Secretaría Nacional de Planificación y Desarrollo (Eds.): 15-27.

Larrea, C. (2011). "Análisis parroquial y social del Referéndum y la Consulta de 2011." Revista La Tendencia, 12: 24-27.

Larrea, C. and L. North (1997). "Ecuador: Adjustment Policy Impacts on Truncated Development and Democratization," Third World Quarterly, 18(5): 913-934.

Larrea, G. (2009). Revolución Ciudadana. Quito: Planeta.

Lemke, T. (2000). "Foucault, Governmentality and Critique." Paper presented at the Rethinking Marxism Conference, September 21-24, University of Amherst, Amherst, USA. 
Lemke, T. (2007). "An Indigestible Meal? Foucault, Governmentality and State Theory," Distinktion: Scandinavian Journal of Social Theory, 15(1): 43-64.

León, M. (2008). El buen vivir: objetivo y camino para otro modelo. In: ILDIS (Ed.), Nueva Constitución: Análisis. Quito: ILDIS-Fredrich Ebert Stiftung-La Tendencia, 36-151.

León, M. (2010). “Reactivación económica para el Buen Vivir: Un acercamiento.” América Latina en movimiento, 452, 23-26.

León Trujillo, J. (2013). “Despolitización y epatía electoral," Linea de Fuego, online edition. Januaray, 24th. Retrieved from: http://lalineadefuego.info/2013/01/24/despolitizacion-y-apatia-electoralpor-jorge-g-leon-trujillo/

Li Murray, T. (2007a). The Will to Improve: Governmentality, Development and the Practice of Politics. Durham: Duke University Press.

Li Murray, T. (2007b). "Practices of Assemblage and Community Forest Management." Economy and Society, 36(2): 263-293.

Lichbach M.I. and A.S. Zuckerman (Eds.) (1997). Comparative Politics: Rationality, Culture and Structure. New York: Cambridge University Press.

Linz, J.J. \& Stepan, A. (Ed.) (1978). The Breakdown of Democratic Regime: Latin America. Baltimore: Johns Hopkins University Press.

Linz, J.J. \& Stepan, A. (Ed.) (1996). Problems of Democratic Transition and Consolidation: Southern Europe, South America and Post-Communist Europe. Baltimore: Johns Hopkins University Press.

Linz, J. and A. Valenzuela (Eds.) (1994). The Failure of presidential democracy, Baltimore: Johns Hopkins University Press.

Lijphart, A. (1971). "Comparative Politics and the Comparative Method." The American Political Science Review, 65 (3): 682-693.

Lipset, S. M. (1960). Political Man: The Social Bases of Politics. New York: Doubleday Anchor Books.

Love, J. L. (2005). "The Rise and Decline of Economic Structuralism in Latin America: New Dimensions," Latin American Research Review, 40(3): 100-25.

Macas, L. (2010). "Diferentes vertientes para un la vida en plenitud." América Latina en Movimiento 452, 14-16. 
Macas, L. (2011). “El Sumak Kawsay: .” In:Weber, G. (Ed.), Debates sobre cooperación y modelos de desarrollo: Perspectivas desde la sociedad civil en el Ecuador. Quito: Centro de Investigaciones CIUDAD, 47-60.

Mainwaring, S. and Torcal. M. (2005). "Party system institutional and party system theory after the third wave of democratization." The Kellogg Institute, Working Paper \#319 - April.. Retrieved from: http://citeseerx.ist.psu.edu/viewdoc/download?rep=rep1\&type=pdf\&doi=1 0.1.1.220.7036

Martínez Novo, C. (2013). “The 'Citizen’s Revolution’ and the Indigenous Movement in Ecuador: Re-centering the Ecuadorian State at the Expense of Social Movements." Paper presented at SARR Conference, "Off Centered States Political Formation and Deformation in the Andes," May 27-29, Quito, Ecuador. Retrieved from: http://sarr.emory.edu/documents/Andes/MartinezNovo.pdf.

Martínez-Novo, C. (Ed.) (2009). Repensando los Movimientos Indígenas, Ecuador: mestizos in Ecuador, Oxford University: Centre for Research on Inequality, Human Security and Ethnicity, WORKING PAPER No. 58. metodológicas,". Retrieved from: www.flacsoandes.org/biblio/catalog/resGet.php?resId=41809

Migdal, J. S. (1988). Strong Societies and Weak States: State-Society Relations and State Capabilities in the Third World. Princeton: Princeton University Press.

Migdal, J. S. (2001). State in Society: Studying How States and Societies Transform and Constitute One Another. Cambridge: Cambridge University Press.

Mignolo, W.D. (2001). “Coloniality of Power and Subalternity." In The Latin American Subaltern Studies Reader, edited by Ileana Rodríguez. Durham and London: Duke University Press.

Mignolo, W. (2005). The Idea of Latin America. Malden: Blackwell.

Miller, N. (2006). "The Historiography of Nations and National Identity in Latin America." Nations and Nationalism, 12(2): 201-221.

Milliken, J. (1999). "The Study of Discourse in International Relations: A Critique of Research and Methods." European Journal of International Relations 5(2): 225-254.

Ministerio de Defensa del Ecuador (2013) "FF.AA. comprometidas con la seguridad del Estado." Retrieved: http://www.defensa.gob.ec/ff-aa-comprometidascon-la-seguridad-del-estado/ 
Ministerio de Turismo de Ecuador (2014). "Mintur participó en feria turistica artesanal y gastronomica." Retrieved from:

http://www.turismo.gob.ec/mintur-participo-en-feria-turistica-artesanal-ygastronomica.

Mohanty, C. T. (2008). “Bajo los ojos de occidente: Academia feminist y discurso colonial”, en Liliana Suárez Navaz y Aída Hernández (eds):

Descolonizando el Feminismo: Teorías y Prácticas desde los Márgenes, ed. Cátedra, Madrid

Monteiro, N. P. and K. G. Ruby (2009). "IR and the False Promise of Philosophical Foundations," International Theory 1(1): 15-48

Montesquieu, C. S. (1977). The spirit of laws: A compendium of the first English edition, Carrithers, D. W., \& Montesquieu, C. S. (Ed.). Berkeley: University of California Press.

Montúfar, C. (2007). "Representation and active citizenship in Ecuador." In Tulchin, J. and M. Ruthenburg (Eds.) Citizenship in Latin America. Boulder y Londres: Lynne Reinner Publishers.

Montúfar, C. (2008). "Estado constitucional de derecho y democracia sustantiva." In J. Echeverría, (Ed.). Plenos poderes y transformación constitucional. Quito: Abya-Yala, Diagonal, 353-396.

Montúfar, C. (2013). ¿Y el decreto 16? El Comercio, September 16 ${ }^{\text {th }}$. Retrieved from:http://www.elcomerciodelecuador.es/cesar_montufar/Decreto_0_994 100610.ml.

Montúfar, C. (2014). “Vivimos en Democracia?” Unpublished, used by permission of the author.

Morais, L. and A. Saahd-Filho (2012). "Neo-Developmentalism and the Challenges of Economic Policy-Making under Dilma Rousseff." Critical Sociology, 38(6): 789-798.

Morner, M. (1967). Race Mixture in the History of Latin America. Boston: Little Brown.

Mosse, D. (2001). “People's Knowledge, Participation and Patronage, Operations and Representations in Rural development. In U. Kothari and B. Cooke (Eds.) (2001). Participation: The new tyranny? London: Zed Books

Muñoz, J. P. (2010). “Gabinetes itinerantes, enlaces, ciudadanos y consejos comunales." Ecuador Debate, 80: 155-178. 
Murat, Arsel (2012). " Between Marx and Markets? The State, The Left Turn and Nature in Ecuador, " Tijdschrift voor economische en sociale geografie, 103 (2), New York: Pantheon Books.

Murillo Miró, J. (1993). Historia del Ecuador. Quito: Corporación Editora Nacional.

Narayan, D. (2005) Measuring Empowerment: Cross-Disciplinary Perspectives Washington: The World Bank).

Narayan et el. (2000) Can Anyone Hear Us? Voices of the Poor, London: Oxofrd University Press, World Bank.

NASA (2006). New Launch Control Room Ready for STS-12 Liftoff. Retrieved: from: http://www.nasa.gov/mission_pages/shuttle/behindscenes/firing_room_4_f. html.

Nelson, C. and L. Grossberg (Eds.) (1988). Marxism and the Interpretation of Culture. Urbana : University of Illinois Press.

North, L. and J. Cameron (Eds.) (2003). Rural Progress, Rural Deca Neoliberal Adjustment Policies and Local Initiatives. Bloomfield, CT: Kumarian Press, Inc.

North, L. (2011). Alternative (New Left) Regimes in the Andes? Latin American and Caribbean Studies Conference paper, Ottawa, April 20-21.

O'Donnell, G. and Schmitter, P. (1986a). Transitions from Authoritarian Rule: Tentative Conclusions about Uncertain Democracies. Baltimore: Johns Hopkins University Press

O'Donnell, G., P. Schmitter and L. Whitehead (Eds.) (1986b). Transitions from Authoritarian Rule: Prospects for Democracy. Baltimore : Johns Hopkins University Press.

O’Donnell, G. (1986). Transitions from Authoritarian Rule. Baltimore: Johns Hopkins

O’Donnell, G. (2007). Dissonances: Democratic Critiques of Democracy. Notre

O’Malley, P. (1996). “Indigenous Governance.” Economy \& Society, 25(3), 310-326.

O'Malley, P., L. Weir and C. Shearing (1997). “Governmentality, Criticism, Politics.” Economy and Society, 26(4): 501-517.

OLCP - Ley Orgánica de Participación Ciudadana (2010). Article 1. Retrieved from: 
http://2009-

2013.observatoriolegislativo.ec/media/archivos_leyes2/7._Texto_definitivo._ 14.pdf, on September 13, 2012

OLCP - Ley Orgánica de Participación Ciudadana (2010). Articles 3. Retrieved from: http://2009-

2013.observatoriolegislativo.ec/media/archivos_leyes2/7._Texto_definitivo._ 14.pdf, on September 13, 2012.

OLCP - Ley Orgánica de Participación Ciudadana (2010). Articles 90-100. Retrieved from: http://2009-

2013.observatoriolegislativo.ec/media/archivos_leyes2/7._Texto_definitivo._ 14.pdf, on September 13, 2012.

Ortiz Lemos, C.A. (2012) La sociedad civi ecuatoriana en el laberinto de la Revolución Ciudadana: Discursos y percepciones en torno a la interrelació estado - sociead civil, en el contexto de la construccion de escenarios participativos, en el proyecto politico de Rafael Correa. Quito, Flacos, Ecuador. Retrieved from: http://www.flacsoandes.org/dspace/handle/10469/5702

Ospina, P. (2010). “Corporativismo, Estado y Revolución Ciudadana: EL Ecuador de Rafael Correa." Instituto de Estudios Ecuatorianos. Copy directly provided by the author.

Ospina, P. (2011). "Ecuador: la Participación ciudadana en el Proyecto de Estado de Rafael Correa." In J.C. Proaño, and N.C. Ruíz (Eds.) Observatorio Latinoamericano, 7, Dossier Ecuador. Buenos Aires, Instituto de Estudios de América Latína y el Caribe, Facultad de Ciencias Sociales, Universidad de Buenos Aires.

Ospina, P. (2012). "Ejes de la política ecuatoriana: medidas disciplinarias, conflicto social y cálculo electoral." Quito: Comité Ecumenico de Proyectos.

Ospina, P. (2013). "La revolución ciudadana en Ecuador: conflicto social, régimen disciplinario y proyecto de Estado." In Cuvi, J., D. Machado, A. Oviedo and N. Sierra (Eds), El correísmo al desnudo. Quito: Montecristi Vive, 26-32.

Owen, D. (1995). "Genealogy as Exemplary Critique: Reflections on Foucault and the Imagination of the Political." Economy and Society, 24(4): 489-506.

Pachano, S. y Garcia (2013). "Ecuador un Regimen Hibrido." Retrieved from: http://campus.usal.es/ acpa/sites/default/files/semin_invest_simon_pacha no_may-2013.pdf 
Pachano, S. (2010). “Gobernabilidad democrática y reformas institucionales y políticas en el Ecuador". In M. Tanaka and F. Jácome, Desafíos de la Gobernabilidad Democrática: Reformas Politico-Institucionales y Movimietos sociales en la región Andina. Caracas, Lima, Ottawa: IERP, IDRC, INVESP. Retrieved from: http://idlbnc.idrc.ca/dspace/bitstream/10625/46490/1/133004.pdf

Pallares, M. (2013) “El fraude de Pegaso y si gran éxito mediático.” El Comercio, April 29, retrieved from: http://www.elcomercio.com/blogs/desde_la_tranquera/Pegaso-sateliteEcuador_7_910178976.html

Polanyi, K. (2001). The Great Transformation. Boston: Beacon Press.

Pratt, M.L. (1991). “Arts of the Contact Zone.” Profession, 33-40.

Pratt, M.L. (1992). Imperial Eyes. Travel Writing and Transculturation. London and New York: Routledge

Prezeworski, A. and Teune P. (1982). The Logic of Comparative Social Inquiry. New York: John Wiley and Sons.

Przeworski, A. (1991). Democracy and the Market. Political and Economic Reforms in Eastern Europe and Latin America. New York: Cambridge University Press.

Przeworski, A. \& Limongi, F. (1997). "Modernization: theories and facts." World Politics 49(2): 155-83.

Priebisch, K. (2007). Globalizing Work, Globalizing Citizenship: Community- Migrant Worker Alliances in Southwestern Ontario." In L. Goldring and P. Vandergeest (eds), Organizing the Transnational: The Experience of Asian, Caribbean and Latin American Migrants in Canada, Vancouver: UBC Press.

Proaño, J.C., Ruíz, N.C. (Eds.) (2011). Observatorio Latinoamericano, 7, Dossier Ecuador. Buenos Aires, Instituto de Estudios de América Latína y el Caribe, Facultad de Ciencias Sociales, Universidad de Buenos Aires.

Quijano, A. (2000). “Coloniality of Power, Eurocentrism, and Latin America." Nepantla: Views from South 1(3), 533-580.

Quijano, A. (2004). El laberinto de América Latina: hay otras salidas? JILAS: Journal of Iberian and Latin American Studies (Australia) 10, no. 2:173-196

Quintero Lopez, R. (2009). “Las innovaciones conceptuales de la constitución del 2008 y el sumak kawsay." In: Acosta, A. (Ed.), El buen vivir. Quito: Abya-Yala, 75-92. 
Radcliffe, S. (2012). "Development for a postneoliberal era? Sumak kawsay, living well and the limits to decolonisation in Ecuador", Geoforum, 43:240-249.

Radcliffe, S. and S. Westwood (1996). Remaking the Nation: Place, Identity and Politics in Latin America. New York: Routledge.

Radcliffe, S. and S. Westwood (1996). Remaking the Nation: Place, Identity and Politics in Latin America. New York: Routledge.

Ramirez, R. (2010). "Socialismo del Sumak Kawsay o Biosocialismo Republicano": Rebellion. Retrieved from: http://www.rebelion.org/noticia.php?id=116667

Ranciére, J. (2001). Ten Thesis on Politics. Theory and Event, 5(3), 1-33.

Ranciére, J. (2006). Hatred of Democracy. London: Verso.

Restrepo, E. (2008). “Cuestiones de método: 'eventualización' y 'problematización' en Foucault." Tabula Rasa, 8: 111-132

Roitman, K. (2008). “'Longos' and 'cholos': Ethnic/'racial' discrimination, among mestizos in Ecuador." Working paper No. 58, Oxford University: Centre for Research on Inequality, Human Security and Ethnicity. Retrieved from: http://r4d.dfid.gov.uk/pdf/outputs/inequality/wp58.pdf

Roitman, K. (2008). 'Longos' and 'cholos': Ethnic/'racial' discrimination, among mestizos in Ecuador, Oxford University: Centre for Research on Inequality, Human Security and Ethnicity, WORKING PAPER No. 58.

Rojas, C. (2001). "Development: What's in a Word? Views from the Paradigms" Canadian Journal of Development Studies, Vol. XXII, No. 3. 571-596

Rojas, C. (2002). Civilization and Violence. Regimes of Representation in Nineteenth Century Colombia. Minnesota.

Rojas, C. (2004). "Governing through the Social: Representations of Poverty and Global Governmentality." In Global Governmentality: Governing International Spaces, W. Larner \& W. Walters (Eds.). London: Routledge, 97-115.

Rojas, C. (2007). “International Political Economy/Development Otherwise.” Globalizations, 4(4): 573-587.

Rojas, C. (2009). "Securing the State and Developing Social Insecurities: The Securitisation of Citizenship in Contemporary Colombia". Third World Quarterly. 30(1), 227-245. 
Rose, N. and P. Miller (1992). "Political Power Beyond the State: Problematic of Government," The British journal of Sociology, 43(2): 173-205

Ross, M. (1997). "Culture and Identity in Comparative Political Analysis", in Mark Lichbach y Alan Zuckerman (eds.), Comparative Politics: Rationality, Culture and Structure. New York: Cambridge University Press.

Ross Schneider, B. (1999). “The Desarrollista State in Brazil and Mexico." In M. WooCummings (Ed.), The Developmental State. Ithaca: Cornell University Press

Rueschemeyer, D., E. H. Stephens and J. D. Stephens (1992). Capitalist Development and Democracy. Chicago: University of Chicago Press.

Ruggie, J. G. (1998). “What Makes the World Hang Together? Neo-Utilitarian and Social Constructivist Challenge," International Organization, 52(4): 855-885.

Rupert, M. (2003). “Globalizing Common Sense: A Marxian-Gramscian (Re-)Vision of the Politics of Governance/Resistance," Review of International Studies 29(S1): 181-198.

Rustow, D. (1970). "Transitions to democracy: Toward a dynamic model." Comparative Politics, 2(3): 337-63.

Said, E. (1994). "From Orientalism," in Patrick Williams and Laura Chrisman, Colonial Discourse and Post-Colonial Theory. New York: Columbia University Press.

Sanjinés, J. (2005). El Espejismo del Mestizaje. La Paz: PIEB.

Santana, R. (1999). Ciudadanos en la Etnicidad: Los Indios en la Política o la Política de los Indios, Quito: Abya-Yala.

Sartori, G. (2005) Party and party Systems: A Framework for Analysis. Cambridge: ECPR Press

Sawyer, S. (2004). Crude Chronicles - Indigenous Politics, Multinational Oil, and Neoliberalism in Ecuador. Durham and London: Duke University Press.

Schiwy, F. (2002). “ ¿Intelectuales subalternos? Notas sobre las dificultades de pensar en diálogo intercultural." In Walsh, C., F Schiwy, S. Castro-Gómez (Eds), Indisciplinar las ciencias sociales: Geopolíticas del conocimiento y colonialidad del poder. Perspectivas desde lo andino. Quito: Universidad Andina Simón Bolívar/Abya-Yala, 103-134.

Scott, J.C. (1985) Weapons of the Weak: Everyday forms of Peasant Resistance. Yale University Press. 
Scott, J.C. (1998). Seeing like a State: How Certain Schemes to Improve the Human Condition Have Failed. Yale University Press.

Secretaría Nacional de Comunicación del Ecuador (2013). "La explotación responsable del Yasuní ayudará a disminuir la pobreza." Retrieved from: http://www.comunicacion.gob.ec/la-explotacion-responsable-del-yasunicontribuira-a-disminuir-la-pobreza/.

Sen, A. (1992). Inequality Re-examined, Cambridge. Harvard University Press.

SENPLADES (2009) Plan Nacional para el Buen Vivir, 2007-2009. Retrieved from: http://plan2007.senplades.gob.ec/

SENPLADES (2010) Plan Nacional Para el Buen Vivir, 2009-2013. Retrieved from: http://plan2007.senplades.gob.ec/

SENPLADES (2011). "Que son las zonas, distritos y circuitos". Retrieved at: http://www.planificacion.gob.ec/folleto-popular-que-son-las-zonasdistritos-y-circuitos.

SENDPLADES (2012). "Proceso de desconcentración del Ejecutivo en los niveles administrativos de planificación." Retrieved at: http://www.planificacion.gob.ec/wpcontent/uploads/downloads/2012/10/Folleto_informativoDesconcentracion2012.pdf.

SENPLADES (2013a). "Que hacemos y quienes somos." Retrieved from: http://www.planificacion.gob.ec/wpcontent/uploads/downloads/2012/08/SENPLADES-Que-hacemos-yquienes-somos.pdf.

SENPLADES (2013b) Biblioteca SENPLADES - Publicaciones. Retrieved from: http://www.planificacion.gob.ec/biblioteca/

SENPLADES (2014). "Plan Nacional Para el Buen Vivir, 2013-2017." Retrieved from: http://www.buenvivir.gob.ec/documents/10157/96c82f1c-5dd8-4a608283-d95d9ed24f0e

SENPLADES (2014). “Good Living National Plan, 2013-2017." Plan Nacional Para el Buen Vivir, 2013-2017," English summary. Retrieved from: http://www.buenvivir.gob.ec/documents/10157/9477fa5f-3a02-488b8dec-e91443ed6155

Stavenhagen, R. (1992). "Challenging the Nation-State in Latin America," Journal of International Affairs 45(2): 421-445. 
Stoller, A. L. (2002). Carnal knowledge and Imperial Power: Race and the Intimate in Colonial Rule. Berkeley: University of California Press.

Stutzman, R. (1981). “El Mestizaje: An All-inclusive Ideology of Exclusion.” In Norman Whitten Jr (ed), Cultural Transformations and Ethnicity in Modern Ecuador. Urbana: University of Illinois Press.

Skocpol, T. (1999). "Bringing the State Back In: Strategies of Analysis in Current Research." In Evans, P.E, D. Rueschemeyer and T. Skocpol (Eds), Bringing the State Back In. (1999).Cambridge: Cambridge University Press, 3-43.

Smedley, A. (1998) "'Race and the Construction of Human Identity," American Anthropologist, New Series, 100(3): 690-702.

Spronk, S. and J. Webber (2007). Struggles Against Dispossession in Bolivia. The Political Economy of Natural Resource Contention, Latin American Perspectives. 34(2): 31-47.

Stoler, A. (1995). Race and the Education of Desire. Durham: Duke University Press

Sylvester, C. (1999). “Development Studies and Postcolonial Studies: Disparate Tales of the "Third World." The Third World Quarterly, 20(4): 703-721.

Tarrow, S. (1995). "Mass mobilization and elite exchange: Democratization episodes in Italy and Spain." Democratization, 2(3): 221-45.

Tikner, J. A. (2005). "What Is Your Research Program? Some Feminist Answers to International Relations Methodological Questions." International Studies Quarterly, 49(1): 1-21.

Tilly, C. (1984). Big Structures, Large Processes, Huge Comparisons, New York: Russell Sage.

Tilly, C. (1992). Coercion, capital, and European states, AD 990-1992. Oxford: Blackwell Publishers Ltd.

Tilly, C. (1999). "War Making and State Making as Organized Crime." In Evans, P.E, D. Rueschemeyer and T. Skocpol (Eds), Bringing the State Back In. (1999).Cambridge: Cambridge University Press, 169-191.

Tocqueville, A. (1966). Democracy in America. J.P Mayer (Ed.), New York: Harper and Row.

Unda, M. (2013). “Modernizatión del capitalismo y reforma del Estado.” In Cuvi, J., D. 
Machado, A. Oviedo and N. Sierra (Eds), El correísmo al desnudo. Quito: Montecristi Vive, 33-38.

Valenzuela, J. S. (1985). Democratización vía reforma: La expansión del sufragio en Chile. Buenos Aires: IDES.

Vélez, C. (2006). La interculturalidad en la educación. Reformas curriculares de Ecuador, Perú y Bolivia. Quito: Universidad Andina Simón Bolívar-Abya Yala.

Villavicencio, A. (2013). ¿Hacia dónde va el proyecto universitario de la Revolución Ciudadana? En J Cuvi et al. El correísmo al desnudo. Quito: Montecristi Vive: 216-231.

Wade, P. (1993). Blackness and Race Mixture: The dynamics of Racial Identity in Colombia, Baltimore: Johns Hopkins University Press.

Wade, P. (2004). "Images of Latin American Mestizaje and the Politics of Comparison," Bulletin of Latin American Research, 23(3).

Walsh, C, F. Schiwy and S. Castro-Gómez (Eds.) (2002). Indisciplinar las ciencias Sociales: Geopolíticas del cononciemiento y colonialidad del poder, perspectivas desde lo Andino. Quito: Abya Yala.

Walsh, C. (2007). "Shifting the Geopolitics of Critical Knowledge." Cultural Studies, 21 (2-3): 224-239.

Walsh, C. (2009). Interculturalidad, Estado y Sociedad: Luchas (de)coloniales de nuestra época. Quito: Abya Yala.

Walsh, C. (2010). "Interculturalidad crítica y educación intercultural," in Construyendo interculturalidad crítica, J. Viaña, L. Tapia \& C. Walsh (Eds.). La Paz: Instituto Internacional de Integración del Convenio Andrés Bello.

Walsh, C. (2010). "Development as Buen Vivir: institutional arrangements and (de)colonial entanglements" Development 53 (1), 15-21.

Walters, W. (2004). “Some Critical Notes on 'Governance'." Studies in Political Economy, 73: 27-46.

Walters, W. and J. H. Haahr (2005). "Governmentality and Political Studies." European political Science, 4: 288-300.

Walters, W. (2012). Governmentality: Critical Encounters. London: Routledge.

Weber, G. (Ed.) (2011). Debates sobre Cooperación y modelos de Desarrollo: 
Perspectivas desde la Sociedad Civil del Ecuador. Quito: Centro de Investigaciones CIUDAD Observatorio de la Cooperaci6n al Desarrollo en Ecuador.

Weber, M. (1983). "The Confucianist Bureaucracy and the Germs of Capitalism in China: The City and the Guilds." In S. Andrevski, MaxWeber on Capitalism, Bureaucracy and Religion: A Selection of Texts. Oxon: Routeledge, 59-84.

Wendt, A. (1998). "On Constitution and Causation in International Relations," Review of International Studies 24(5): 101-117

Woo-Cummings, M. (Ed.) (1999). The Developmental State. Ithaca: Cornell University Press.

Yanez, N.A. (2006) “Reconocimientos legislativos de los derechos ambientales indígenas en el ámbito internacional." In Berraondo, M. (Coord.), Pueblos Indigenas y Derechos Humanos. Bilbao: Universidad de Deusto, 489-508.

Yashar, D. (1999)."Democracy, Indigenous Movements, and the Postliberal Challenge in Latin America." World Politics, 52(1), 76-104.

Yashar, D. (2005). Contesting Citizenship in Latin America. The Rise of Indigenous Movements and the Postliberal Challenge. Cambridge: Cambridge University Press.

WRP - Presidencia de la República del Ecuador (2010-2013). Weekly Presidential Report, \#160-340. Retrieved from: http://enlaceciudadano.gob.ec

WRP - Presidencia de la República del Ecuador (2010). Weekly Presidential Report, \#163. March, $13^{\text {th }}$. Retrieved from: https://archive.org/details/EnlaceCiudadano163

WRP - Presidencia de la República del Ecuador (2012a). Weekly Presidential Report, \#259. February, $18^{\text {th }}$. Retrieved from:

http://www.youtube.com/watch?v=1IZLESsHpAg

WRP - Presidencia de la República del Ecuador (2012b). Weekly Presidential Report, \#260. February, $25^{\text {th }}$. Retrieved from:

http://www.youtube.com/watch?v=19ZpAX-3Qzw

WRP - Presidencia de la República del Ecuador (2012c). Weekly Presidential Report, \#261. March, $3^{\text {rd }}$. Retrieved from: http://www.youtube.com/watch?v=z1QR2N_WNK4 
WRP - Presidencia de la República del Ecuador (2012d). Weekly Presidential Report, \#262. March, $10^{\text {th }}$. Retrieved from:

http://www.youtube.com/watch?v=rIdEaivEe0I

WRP - Presidencia de la República del Ecuador (2012e). Weekly Presidential Report, \#263. March, $17^{\text {th }}$. Retrieved from:

http://www.youtube.com/watch?v=cHB1i7oNAtA

WRP - Presidencia de la República del Ecuador (2012f). Weekly Presidential Report, \#264. March, 24th. Retrieved from:

http://www.youtube.com/watch?v=QNgTwZXN37I

WRP - Presidencia de la República del Ecuador (2012g). Weekly Presidential Report, \#286. August, $25^{\text {th }}$. Retrieved from:

http://www.youtube.com/watch?v=f2BMVV9nHMk

WRP - Presidencia de la República del Ecuador (2012h). Weekly Presidential Report, \#292. October, $06^{\text {th }}$. Retrieved from:

http://enlaceciudadano.gob.ec/enlaceciudadano292/

WRP - Presidencia de la República del Ecuador (2012i). Weekly Presidential Report, \#293. October, $13^{\text {th }}$. Retrieved from:

http://enlaceciudadano.gob.ec/enlaceciudadano293/

WRP - Presidencia de la República del Ecuador (2012j). Weekly Presidential Report, \#295. October, $2^{\text {th }}$. Retrieved from:

http://www.youtube.com/watch?v=STAmm58QV2M.

Zibechí, R. (2009). “Ecuador: the battle for natural resources deepens,” Americas Program Report, Americas Program online, Retrieved from: http://www.cipamericas.org/archives/1904 


\section{APPENDIX 1: LIST OF INTERVIEWS}

- Former AP Member and State Official during the early days of Correismo; interview topic: Participation in AP and the early stages of Correismo Quito, June $14^{\text {th }}, 2012$.

- Researcher; interview topic: Participation in Ecuador in historical perspective. Quito, September 10 2012.

- Researcher; interview topic: Participation in Ecuador in historical perspective. Quito, September 14, 2012.

- Government Official in Participatory Planning; interview topic: participation, Indigenous Peoples and the State. Quito, June 10 ${ }^{\text {th }}, 2013$.

- Government Official in Participatory Planning; interview topic: participation, Indigenous Peoples and the State. Latacunga, August, 15th, 2012

- Government Official in Participatory Planning; interview topic: participation, Indigenous Peoples and the State. Quito, October 10 $0^{\text {th }}, 2012$

- Government Official in Educational Reform; interview topic, educational reform. Quito, October, 22 $2^{\text {nd }}, 2012$

- Indigenous leader; interview topic: participation, Indigenous Peoples and the State. Quito, November 14th 2012.

- Indigenous Activist; interview topic: participation, Indigenous Peoples and the State. Quito, November 19th 2012.

- Indigenous leader; interview topic: participation, Indigenous Peoples and the State. Quito, November 21st, 2012.

- Indigenous leader; interview topic: participation, Indigenous Peoples, education and the State. Quito, November 28 ${ }^{\text {th }}, 2012$.

- Indigenous leader; interview topic: participation, Indigenous Peoples and the State. Quito, November 29th 2012.

- Indigenous governmental official. Interview topic: participation, Indigenous Peoples, education and the state. Quito, November $28^{\text {th }}, 2012$.

- Indigenous government official. Interview topic: participation, Indigenous Peoples, education and the state. Quito, December $10^{\text {th }}, 2012$.

- Governmental official. Interview topic: Governmental reform, education and participation. Quito, February $4^{\text {th }}, 2013$.

- Non-governmental Organization Activist. Interview topic: The state, civil society and participation, August $5^{\text {th }}, 2012$.

- Non-governmental organization activist. Interview topic: The state, civil society and participation, August $5^{\text {th }}, 2012$.

- Participant, PNBV Workshop; interview topic (unstructured interview): Participation in the PNBV Workshops. Ibarra, September 25th 2012.

- Participant, PNBV Workshop; interview topic (unstructured interview): Participation in the PNBV Workshops. Ibarra, September 25th 2012.

- Participant, PNBV Workshop; interview topic (unstructured interview): Participation in the PNBV Workshops. Ibarra, September 25 2012.

- Participant, PNBV Workshop; interview topic (unstructured interview): Participation in the PNBV Workshops. Ibarra, September 25th 2012. 
- Participant, PNBV Workshop; interview topic (unstructured interview): Participation in the PNBV Workshops. Quito, October 8th 2012.

- Participant, PNBV Workshop; interview topic (unstructured interview): Participation in the PNBV Workshops. Latacunga, July 26th, 2012 


\section{APPENDIX 2: LIST OF 2013-2017 PNBV WORKSHOPS}

- Santa Elena Workshop, Santa Elena, June 27, 2012; number of participants, 180

- Guaranda Workshop, Bolívar, July, 5th 2012; number of participants, 180

- Milagro Workshop, Guayas, $12^{\text {th }}$ July, 2012; number of participants: over 120

- Latacunga Workshop, Cotopaxi, July 26 2012 ; number of participants, 33

- Quevedo Workshop, Los Ríos, July, 31 ${ }^{\text {st }}$ 2012; number of participants, 187

- Riobamba Workshop, Chimborazo, August 9th, 2012; number of participants 18

- Sangolquí Workshop, Rumiñahui (Pichincha), August n/a, 2012; number of participants, 15.

- Esmeraldas Workshop, Esmeraldas, August n/a, 2012; number of participants, 19

- Ibarra Workshop, September 25th; number of participants approximately 30.

- Quito Workshop, October 8 $8^{\text {th }}, 2012$; number of participants, 14

- Cayambe Workshop, Imbabura, October 10 $10^{\text {th }}, 2012$; number of participants 23

- Cuenca Workshop, October 26 ${ }^{\text {th }}, 2012$; number of participants, N/A.

- Ambato Workshop, Tungurahua, November $5^{\text {th }}, 2012$; number of participants, N/A. 